JOICE RUIZ BERNIER

\title{
O ADMINISTRADOR JUDICIAL NA RECUPERAÇÃO JUDICIAL E NA FALÊNCIA
}

DISSERTAÇÃO DE MESTRADO

Orientador Professor Francisco Satiro de Souza Júnior

FACULDADE DE DIREITO DA UNIVERSIDADE DE SÃO PAULO

$$
\begin{gathered}
\text { SÃO PAULO } \\
2.014
\end{gathered}
$$




\section{JOICE RUIZ BERNIER}

\section{O ADMINISTRADOR JUDICIAL NA RECUPERAÇÃO JUDICIAL E NA FALÊNCIA}

Dissertação de Mestrado apresentada à Faculdade de Direito da Universidade de São Paulo para obtenção do título de Mestre.

Área de concentração: Direito Comercial.

Orientador: Professor Doutor Francisco Satiro de Souza Júnior

FACULDADE DE DIREITO DA UNIVERSIDADE DE SÃO PAULO

SÃO PAULO

2.014 


\section{O ADMINISTRADOR JUDICIAL NA RECUPERAÇÃO JUDICIAL E NA FALÊNCIA}

Dissertação aprovada como requisito parcial para a obtenção do grau de Mestre em Direito Comercial no Programa de Pós-Graduação Strictu Sensu da Faculdade de Direito da Universidade de São Paulo, pela seguinte Banca Examinadora:

Orientador: Prof. Dr. Francisco Satiro de Souza Júnior

Membros:

São Paulo, de de 2.014 . 
Dedicatória

A minha filha Júlia. 


\section{Agradecimentos}

A Deus.

À Faculdade de Direito da Universidade de São Paulo, ao meu orientador, Prof. Dr. Francisco Satiro de Souza Júnior, pela dedicação na orientação concedida, e ao Dr. Paulo Fernando Campos Salles de Toledo, inspirador de grande parte da minha pesquisa.

Aos meus pais, Consuelo e Serafin, às minhas irmãs Cristina e Encarnación, e a meu marido Fábio, pelo amor incondicional, apoio e compreensão, em todos os momentos da minha vida.

Aos verdadeiros amigos, que me incentivaram a fazer e, principalmente, a concluir este mestrado, não obstante todos os percalços do caminho, e em especial a Fernando Dias Menezes de Almeida, companheiro fiel há 25 anos. 


\section{RESUMO}

\section{BERNIER, Joice Ruiz. O ADMINISTRADOR JUDICIAL NA RECUPERAÇÃO}

JUDICIAL E NA FALÊNCIA. 2014. 168 f. Dissertação de Mestrado. Faculdade de Direito. Universidade de São Paulo, 2014.

A presente dissertação de mestrado tem por escopo a análise do administrador judicial na recuperação judicial e na falência, de acordo com a Lei $n^{\circ} 11.101 / 05$. Entre as grandes mudanças advindas com a introdução da citada lei, está a figura do administrador judicial, em substituição à do antigo comissário da concordata e do síndico na falência. Não obstante serem aplaudidas muitas das alterações já incorporadas há quase 10 (dez) anos, o regime jurídico do administrador judicial não é isento de problemas e lacunas, ainda não discutidos na sua totalidade pela doutrina e jurisprudência pátria. De fundamental importância o entendimento desta figura jurídica para que as demais inovações constantes da lei sejam aplicadas de forma completa e eficaz, atingindo-se, assim, seus fins primordiais. Para tanto, iniciamos com um breve estudo das soluções possíveis para as empresas em crise, com base na Lei $\mathrm{n}^{\mathrm{o}} 11.101 / 05$, traçando os seus pontos mais significativos e que tenham relação com o tema proposto (capítulo 1). Apresentamos uma breve análise histórica da figura do agora denominado administrador judicial, com base na legislação e na doutrina brasileira (capítulo 2). O estudo prossegue analisando a natureza jurídica do administrador judicial. Serão analisados também os pressupostos legais, impedimentos e o critério discricionário do juízo para a sua nomeação, com a confrontação do direito comparado. Discorremos sobre os deveres e as atribuições do administrador judicial, instituídos pela Lei $\mathrm{n}^{\circ} 11.101 / 05$, tanto na recuperação judicial como na falência, inclusive para a hipótese de prosseguimento da atividade negocial na falência. Estudamos a responsabilidade do administrador judicial segundo a legislação e jurisprudência pátrias, especialmente nas esferas cível, penal e tributária. Também tratamos das hipóteses e respectivas consequências da substituição e destituição do administrador judicial, disciplinadas na Lei $\mathrm{n}^{\circ} 11.101 / 05$, e os critérios legais para a sua remuneração (capítulo 3). A dissertação termina com as considerações finais em relação ao estudo realizado (capítulo 4).

Palavras Chaves: Administrador Judicial; Recuperação Judicial; Falência. 


\begin{abstract}
BERNIER, Joice Ruiz. THE ROLE OF THE JUDICIAL ADMINISTRATOR IN REORGANIZATION AND BANKRUPTCY. 2014. 168 p. Master's Degree Thesis. School of Law. University of São Paulo, 2014.
\end{abstract}

This master's degree thesis examines the role of the judicial administrator in reorganization (judicial recovery) and bankruptcy procedures, according to Law 11.101/05. Among the important changes brought by the enactment of this law is the figure of the judicial administrator, substituting the former trustee in moratorium ("concordata") and bankruptcy procedures. Although it is acknowledged many improvements introduced by the new regime almost ten years ago, the role of the judicial administrator is not exempt from problems and gaps, which so far have not been fully discussed by the doctrine and jurisprudence. It is of fundamental importance to understand this legal figure for the other innovations contained in the law to be completely and effectively applied, to reach the main goals of the law. For this purpose, we start with a study of the possible solutions available to distressed companies, based on Law 11.101/05, tracing out its most significant points that are related to the theme (chapter 1). Then we present a brief historical analysis of the figure now called the judicial administrator, in light of Brazilian legislation and doctrine (chapter 2). The study continues with the analysis of the legal nature of the judicial administrator (chapter 3 ). In this chapter, we also analyze the legal prerequisites, impediments and discretionary criteria for appointing people to this position, in light of comparative law. We examine the duties and powers of judicial administrator, as established by Law 11.101/05, both in reorganization and bankruptcy, including the possibility of continuing the company's business activity during the bankruptcy process. Another aspect examined is the potential liability of the judicial administrator according to the nation's legislation and jurisprudence, especially in the civil, criminal and tax areas. We also cover the situations and respective consequences of the replacement and removal of the judicial trustee in accordance with Law 11.101/05, and the legal criteria for his remuneration (chapter 3). The dissertation concludes with final remarks regarding the study (chapter 4$)$.

Key Words: Judicial Administrator; Reorganization; Bankruptcy. 


\section{SIGLAS}

Al.

AGC

Ag.

Ag.Rg.

AI

Art.

Ap Civ.

$\mathrm{CC}$

CF

Cf.

CIRE

(Decreto-Lei 53/04)

Coord.

$\mathrm{CP}$

CPC

CTN
Alínea

Assembleia Geral de Credores

Agravo

Agravo Regimental

Agravo de Instrumento

Artigo

Apelação Cível

Código Civil - Lei 10.406/2.002

Constituição Federal

Conferir

Código de Insolvência e da Recuperação de Empresas de Portugal

Coordenador

Código Penal - Decreto-Lei/1.940

Código de Processo Civil - Lei 5.863/1.973

Código Tributário Nacional - Lei 5.172/1.966 
Des.

DL

EBRD

EDcl.

$\mathrm{g} / \mathrm{n}$

Inc.

j.

LF

LRE

LSA

Min.

$\mathrm{n} . / \mathrm{n}^{\circ}$

Org.

p.

Rel.

REsp

$\mathrm{RC}$
Desembargador

Decreto-Lei

European Bank for Reconstruction and Development

Embargos de Declaração

grifo nosso

Inciso

julgado

Decreto-Lei 7.661/1.945

Lei de Recuperação de Empresas e Falências -Lei 11.101/2.005

Lei das Sociedades por Ações - Lei 6.404/1.976

Ministro

número

Organizador

Página

Relator

Recurso Especial

Recurso crime 
RHC

RMS

RO

ss.

STF

STJ

TJ

U.S. Trustees

USC

V./Vol.

v.u.
Recurso Ordinário em Habeas Corpus

Recurso Ordinário em Mandado de Segurança

Recurso Ordinário

seguintes

Supremo Tribunal Federal

Superior Tribunal de Justiça

Tribunal de Justiça

United States Trustees

United States Code

Volume

votação unâmine 


\section{SUMÁRIO}

1. Introdução - A empresa em crise e a Lei de 11.101/05 ................................................. 14

2. Breve análise histórica do administrador judicial na legislação ................................... 22

2.1 Código Comercial de 1.850 (Lei 556 de 1.850) ....................................................... 23

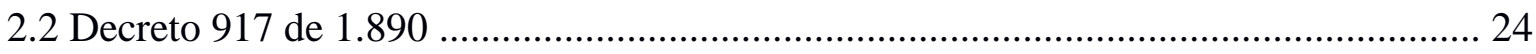

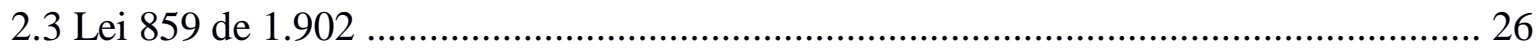

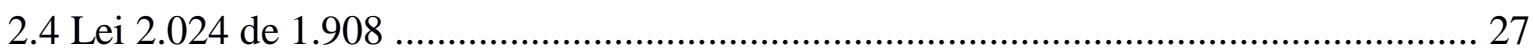

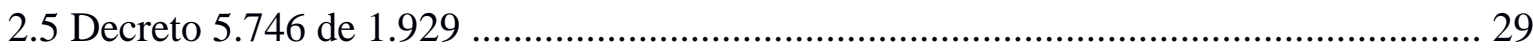

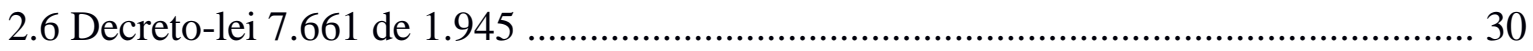

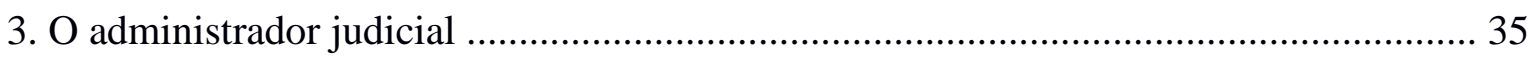

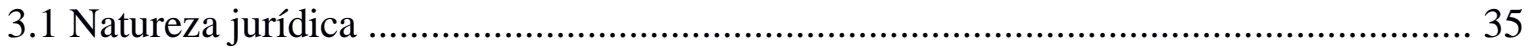

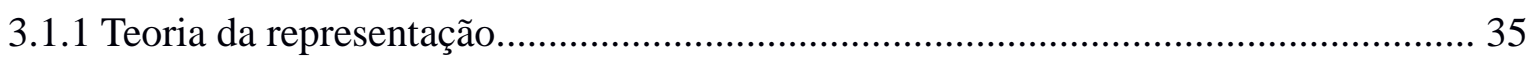

3.1.2 Teoria do ofício ou da função judiciária ............................................................... 37

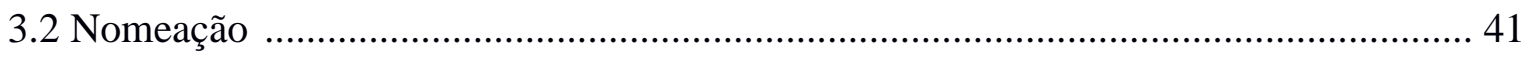

3.2.1 Requisitos legais e critérios adotados para a nomeação ....................................... 42

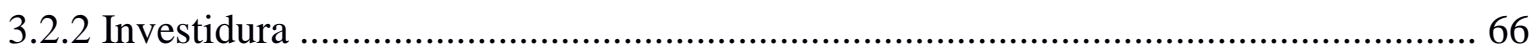

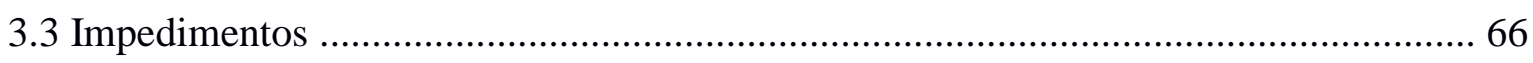

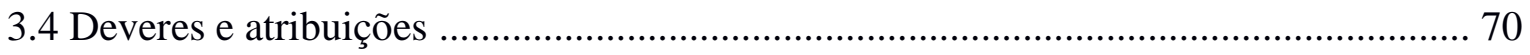

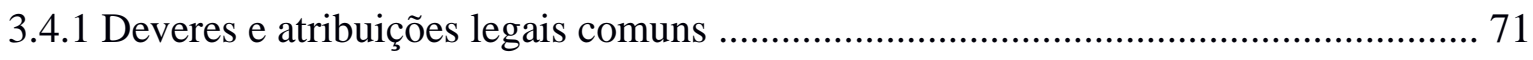

3.4.1.1 Envio de correspondências aos credores ........................................................... 71

3.4.1.2 Fornecimento de informações solicitadas pelos credores interessados .................. 73

3.4.1.3 Fornecimento de extratos de livros do devedor ................................................. 74 
3.4.1.5 Verificação dos créditos, elaboração da relação de credores, consolidação do quadro-geral de credores e publicação de editais 75

3.4.1.6 Requerimento de convocação e presidência da assembleia-geral de credores 79

3.4.1.7 Contratação de auxiliares 81

3.4.1.8 Manifestação nos casos previstos em lei e sempre que necessário 83

3.4.2 Deveres e atribuições legais exclusivos da recuperação judicial 84

3.4.2.1 Fiscalização das atividades do devedor, com a apresentação de relatórios mensais 84

3.4.2.2 Fiscalização do cumprimento do plano, com requerimento de falência no caso de descumprimento de obrigação ali assumida 88

3.4.2.3 Gestão do devedor 89

3.4.2.4 Prestação de contas 92

3.4.3 Deveres e atribuições legais exclusivos da falência... 92

3.4.3.1 Aviso aos credores sobre o acesso aos livros e documentos do falido 93

3.4.3.2 Exame da escrituração do devedor 93

3.4.3.3 Recebimento da correspondência dirigida ao devedor .94

3.4.3.4 Apresentação de relatório sobre as causas e circunstâncias que conduziram à situação de falência .95

3.4.3.5 Arrecadação, avaliação e guarda de bens do devedor 97

3.4.3.6 Realização do ativo e pagamento dos credores 103

3.4.3.7 Representação da massa em juízo ou fora dele 107

3.4.3.8Entrega ao seu substituto de todos os bens e documentos da massa em seu poder 108 3.4.3.9 Apresentação de conta demonstrativa da administração, da prestação final de contas e de relatório final de falência 109 


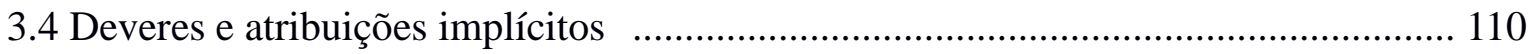

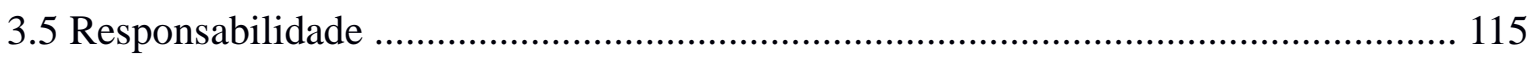

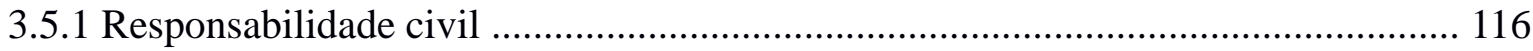

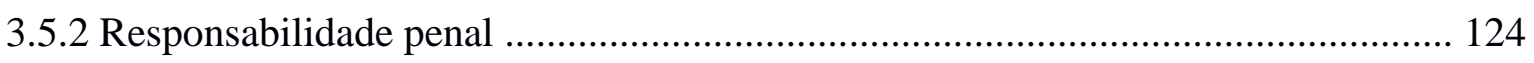

3.5.3 Responsabilidade tributária …………………………………………………...... 129

3.6 Hipóteses de substituição e destituição ……………………………………………..... 133

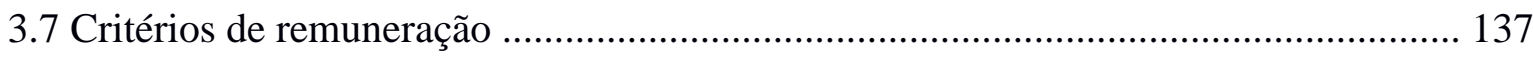

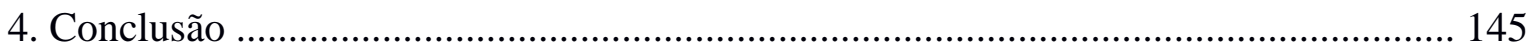

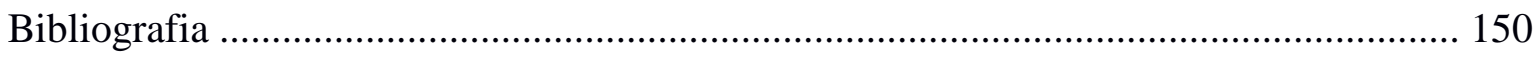




\section{Introdução - A empresa em crise e a Lei de 11.101/05.}

Desde a origem do direito concursal, verificamos a evolução de sua finalidade, de inicio punitiva e liquidatória e de cunho privatístico, com a simples retirada do devedor do mercado e distribuição do seu patrimônio entre os credores, para, hodiernamente, assumir um aspecto publicístico, com o interesse do Estado na preservação da empresa que esteja em crise, mas que seja economicamente viável, e na manutenção da atividade produtiva, dos postos de trabalho e do mercado em geral.

Segundo Joaquin Bisbal Mendez, do ponto de vista econômico, o tratamento conferido às empresas em crise ao longo da história moderna pode ser estudado por dois métodos, a saber: o método de mercado e o método governativo ${ }^{1}$. O método de mercado parte do pressuposto que todos os devedores em crise são iguais ou sem diferenças substanciais que denotem um tratamento diferenciado; os fundamentos das crises também têm natureza semelhante, já que demonstram a impossibilidade de satisfazer os credores; e os credores diferem entre si apenas nos valores de seus créditos. Trata-se de um método de composição de interesses privados ou, em suas palavras, "um método geral, liquidatório e judicial". Já pelo método de governativo, tanto os devedores como as razões da crise são diferentes; e os credores também podem pertencer a diversas categorias, inclusive com interesses conflitantes entre si. Verifica-se ser um método de conservação da empresa, de composição de interesses privados e públicos. E a melhor maneira de satisfação dos interesses envolvidos é através de um plano de reorganização da empresa, com a intervenção de órgãos e critérios administrativos, ou seja, do Estado, em face das distorções do mercado e pela diversidade de interesses a serem tutelados. Por tais razões, classifica o método como "especial, conservativo e administrativizado)".

Assim, mesmo sem ser possível a adoção de um sistema falimentar único, face aos aspectos econômicos, sociais, jurídicos e culturais peculiares de cada país, com a evolução do tempo atingiu-se uma nova percepção sobre a necessidade de um duplo caminho para a solução das empresas em crise, através da reorganização das empresas

\footnotetext{
${ }^{1}$ MENDEZ, Joaquin Bisbal. La empresa en crisis y el derecho de quiebras (Una aproximación económica y jurídica a los procedimientos de conservación de empresas). Bolonha: Real Colegio de España, 1.986, p. 3335.
} 
viáveis e a liquidação do devedor, cuja preservação do negócio já não mais se apresenta como possível ${ }^{2}$.

O princípio da preservação da empresa foi sendo consagrado pelas legislações estrangeiras, tendo como grandes destaques a legislação norte-americana, com Bankruptcy Reform Act de 1.978, e a francesa, através da promulgação da Lei 85-98 de 1.985, e culminou com uma convergência na adoção dos "Principles and Guidelines for Effective Insolvency and Creditor Rights Systems" ("Princípios e Orientações para Sistemas Eficientes de Insolvência e Direitos de Credores"), publicados pelo Banco Mundial, em abril de $2.001^{3}$, com o objetivo de determinar critérios mínimos necessários para a eficiência dos sistemas de insolvência, baseados nas melhores práticas internacionais.

No Brasil, o Decreto Lei $n^{\circ} 7.661 / 45$ (LF), idealizado em um período de economia predominantemente agrária e que visava ao pequeno comerciante em nome individual $^{4}$, já não se adequava à realidade econômica brasileira e internacional, já praticamente na virada para o século XXI,. A LF não favorecia um ambiente de negociação entre credores e o devedor e também não era capaz de preservar a função social da empresa, levando inclusive à deterioração de importantes ativos, em face da morosidade dos processos falimentares até então existentes, razão pela qual perdiam "os empresários, os trabalhadores, os credores e o Poder Público", ou seja, "toda a sociedade brasileira", consoante ressaltado por Marcos de Barros Lisboa, Otávio Ribeiro Damaso, Bruno Carazza dos Santos e Ana Carla Abrão Costa ${ }^{5}$.

Uma das críticas feitas à LF era justamente não regular a reorganização da empresa, já que referido diploma legal previa única e exclusivamente os institutos da

\footnotetext{
2 PUGLIESI, Adriana Valéria. Direito Falimentar e Preservação da Empresa. São Paulo: Quartier Latin, 2.013, p. 41.

${ }^{3}$ WORLD BANK. Principles and Guidelines for Effective Insolvency and Creditor Rights Systems. Disponível http://www.worldbank.org/ifa/Insolvency\%20Principles\%20and\%20Guidelines\%20April\%202001.pdf. Acesso em 17/04/14.

${ }^{4}$ TOLEDO, Paulo Fernando Campos Salles de. A empresa em Crise no Direito Francês e Americano. Dissertação de mestrado. Faculdade de Direito da Universidade de São Paulo. São Paulo, 1.987, p. 2.

${ }^{5}$ LISBOA, Marcos de Barros, DAMASO, Otávio Ribeiro, SANTOS, Bruno Carazza dos, COSTA, Ana Carla Abrão. A Racionalidade Econômica da Nova Lei de Falências e de Recuperação de Empresas. In: PAIVA, Luiz Fernando Valente de (coord.). Direito Falimentar e a nova lei de falências e recuperação de empresas. São Paulo: Quartier Latin, 2.005, p. 41-43.
} 
falência ou da concordata, os quais, não permitiam que o até então "comerciante" em crise mas que econômica e financeiramente viável, se recuperasse ${ }^{6}$.

A concordata preventiva era considerada "um favor, que o Estado, através do Poder Judiciário, concede ao devedor comerciante, infeliz e de boa fé", e tinha por objeto somente "a regularização das relações patrimoniais entre o devedor e seus credores quirografários e por fim evitar a declaração da falência"» ${ }^{\text {. }}$

Segundo Paulo Fernando Campos Salles de Toledo ${ }^{9}$, a falência significava a "morte da empresa", enquanto que a concordata somente concedia um prazo maior para pagamento de "talvez uma quantia menor", visando a "salvar a empresa" da quebra, e, muitas vezes, apenas a postergar uma falência inevitável no futuro sem, no entanto, recuperá-la e/ou analisar as causas que levaram o devedor a essa situação e sua viabilidade econômico-financeira para prosseguimento.

Com efeito, em conferência proferida no Instituto dos Advogados Brasileiros, no Rio de Janeiro, em 08 de março de 1974, Rubens Requião já alertava que a falência, da forma prevista na LF, era tão "ruinosa para os credores" que, por não terem outra saída, acabam por optar "pela esperança, raramente realizada, de receber migalhas de seu crédito" pela concordata. Ainda segundo o autor, a concordata, concedida apenas com base no preenchimento dos requisitos legais, sem a análise das verdadeiras causas da insolvência e da verificação da existência ou não de um plano viável para a reorganização da empresa, nada mais era que "um meio hábil de enriquecimento dos devedores mais sagazes e menos escrupulosos" 10 .

$\mathrm{Na}$ verdade, o sistema previsto na LF possibilitava continuação de empresas inviáveis e, pela sua inflexibilidade, muitas vezes impedia que as sociedades viáveis se

\footnotetext{
${ }^{6}$ BEZERRA FILHO, Manoel Justino, Lei de Recuperação de Empresas e Falências Comentada, $5^{\mathrm{a}}$ ed. São Paulo: Revista dos Tribunais, 2.008, p. 40.

${ }^{7}$ VALVERDE, Trajano de Miranda. Comentários à Lei das Falências. (Decreto-lei $n^{\circ} 7.661$, de 21 de junho de 1945). Vol. III (art. 114 a 199). $2^{\mathrm{a}}$ ed. Rio de Janeiro: Revista Forense, 1.955, p. 264.

${ }^{8}$ VALVERDE, Trajano de Miranda. Idem, p. 183.

9 TOLEDO, Paulo Fernando Campos Salles de. A reforma da Lei de Falências e a Experiência do Direito Estrangeiro. In: Homenagem a Roger Carvalho Mange. Revista do Advogado n. 36, São Paulo: AASP, 1.992, p. 82.

${ }^{10}$ REQUIÃO, Rubens. A Crise do Direito Falimentar Brasileiro - Reforma da Lei de Falências. Revista de Direito Mercantil, vol. 14, São Paulo: Revista dos Tribunais, 1.974, p. 28.
} 
reerguessem com a negociação de suas dívidas com seus credores. Por tais razões, conclui Paulo Fernando Campos Salles de Toledo, a única solução jurídica para o prosseguimento da empresa em crise, não era "socialmente útil" ou economicamente adequado, mas sim juridicamente ultrapassado $^{11}$.

Neste espírito de adequação do sistema falimentar brasileiro à nova realidade econômica brasileira e internacional, foi promulgada a Lei 11.101, em 9 de fevereiro de 2.005 (Lei de Recuperação de Empresas e Falências ou LRE), adotando o método governativo de Joaquin Bisbal Mendez e seguindo em boa parte os princípios e diretrizes dados pelo Banco Mundial.

Os princípios norteadores da recuperação de empresas e também da falência estão interligados entre si e assim devem ser interpretados. Eles encontram-se especificados no parecer 534/04 de relatoria do falecido ex-senador Ramez Tebet, constante do projeto de lei complementar n. $71 / 2.003^{12}$, a saber: i) princípio da preservação da empresa; ii) princípio da separação dos conceitos de empresa e empresário; iii) princípio da recuperação das sociedades e dos empresários recuperáveis; iv) princípio da retirada do mercado das sociedades e dos empresários não recuperáveis; v) princípio da proteção aos trabalhadores; vi) princípio da redução do custo do crédito no Brasil; vii) princípio da celeridade e da eficiência dos processos judiciais; viii) princípio da segurança jurídica; ix) princípio da participação ativa dos credores; x) princípio da maximização do valor dos ativos do falido; xi) princípio da desburocratização da recuperação de microempresas e empresas de pequeno porte; e xii) princípio do rigor na punição de crimes relacionados à falência e à recuperação judicial.

Tendo como fonte de inspiração os princípios acima relacionados, a LRE acompanha a tendência mundial de adoção de um regime para a reorganização das empresas viáveis e outro para a liquidação das sociedades cujo prosseguimento já não seja mais possível. Neste sentido, o regime de liquidação é mantido através da falência (artigos 75 a 160) e a reorganização pode ser feita por um dos 3 (três) meios previstos em lei, a

\footnotetext{
${ }^{11}$ TOLEDO, Paulo Fernando Campos Salles de. A reforma da Lei de Falências e a Experiência do Direito Estrangeiro. In: Homenagem a Roger Carvalho Mange. Revista do Advogado n. 36, São Paulo: AASP, 1.992, p. 82.

12 TEBET, Ramez. Parecer 534/04 sobre o Projeto de Lei Complementar n. 71/2.003. Disponível em: http://redir.stf.jus.br/paginadorpub/paginador.jsp?docTP=TP\&docID=580930. Acesso em 01/07/14.
} 
saber: a recuperação judicial (artigos 47 a 72), a recuperação extrajudicial (artigos 161 a 166) ou o acordo privado (artigo 167).

Nos termos claros do artigo 47 da LRE, o instituto da recuperação judicial visa, primordialmente, à superação da crise econômico-financeira para que sejam preservados a sociedade empresária e a empresa individual, sempre que economicamente viáveis. Com a preservação do devedor, atingir-se-ão as demais finalidades da lei, quais sejam, a manutenção da fonte produtora, do emprego dos trabalhadores e dos interesses dos credores, além de se estimular a atividade econômica, com o fomento da produção de bens e serviço, e, assim, cumprir a sua função social e contribuir para o crescimento e desenvolvimento do País ${ }^{13}$.

A LRE também confere a possibilidade de preservação da empresa através da recuperação extrajudicial. Por este instituto, o devedor poderá, desde que preenchidos os mesmos requisitos necessários para requerimento da recuperação judicial ${ }^{14}$, propor e negociar diretamente com seus credores plano de recuperação extrajudicial, o qual poderá ou não ser submetido à homologação judicial ${ }^{15}$.

Caso o devedor não preencha as exigências necessárias para interposição da recuperação extrajudicial, a LRE ainda prevê a possibilidade de do acordo privado entre o devedor e seus credores. Com efeito, consoante destaca Francisco Satiro de Souza Júnior ${ }^{16}$, tanto o acordo privado, como o plano de recuperação extrajudicial não homologado judicialmente $^{17}$, reafirmam o princípio da autonomia privada e sepultam a "punição" dada pela $\mathrm{LF}^{18}$, que caracterizava o estado de falência se o devedor convocasse seus credores e lhes propusesse dilação, remissão de créditos ou cessão de bens, fora do procedimento da concordata.

\footnotetext{
13 TOLEDO, Paulo Fernando Campos Salles de. Recuperação judicial, a principal inovação da Lei de Recuperação de Empresas - LRE. In: A Nova Lei de Falências e de Recuperação de Empresas. Revista do Advogado, n. 83, São Paulo: AASP, 2.005, p. 102/103.

${ }^{14}$ Art. 48, LRE.

${ }^{15}$ Arts. 162 e 163 , LRE.

${ }^{16}$ SOUZA JÚNIOR, Francisco Satiro. In: SOUZA JUNIOR, Francisco Satiro de, e PITOMBO, Antônio Sérgio de A. Moraes. (coord.). Comentários à Lei de Recuperação de Empresas e Falência. Lei 11.101/2005. - Artigo por Artigo. $2^{\mathrm{a}}$ ed. São Paulo: Revista dos Tribunais, 2.007, p. 542-543.

${ }^{17}$ Desde que os credores signatários tenham expressamente concordado com sua validade, independemente de homologação judicial, ou tenham ratificado seus termos após a rejeição pelo juiz, cf. art. 165, LRE.

${ }^{18}$ Art. $2^{\circ}$, inc. III, LF.
} 
Não obstante a LRE prestigiar as "soluções reorganizatórias"19, Fabio Ulhoa Coelho ressalta que "a recuperação da empresa não deve ser vista como um valor jurídico a ser buscado a qualquer custo" ${ }^{20}$. Na hipótese de inviabilidade econômico-financeira do devedor, a falência é a medida judicial imposta pelo sistema legal brasileiro.

Note-se que a falência não significa a extinção da empresa, mas a busca de solução sem a participação do empresário já que, nos termos do artigo 75 da LRE, o objetivo da falência é a preservação e a otimização produtiva dos bens, ativos e recursos produtivos da empresa sempre que possível. Desta forma, o Estado deve promover da forma mais rápida possível a eliminação do mercado do devedor cuja viabilidade de prosseguimento não mais existir, com uma eficaz realização do ativo, a fim de se evitar a potencialização e o agravamento da situação, transferindo-se o risco da atividade empresarial do empresário para os credores.

Segundo as lições de Oscar Barreto Filho, podemos definir o estabelecimento como o "complexo de bens, materiais e imateriais, que constituem o instrumento utilizado pelo comerciante para a exploração de determinada atividade mercantil”,21 . Já o aviamento, um dos atributos do estabelecimento, representa a mais valia que a universalidade de bens adquire, em contrapartida ao valor dos bens considerados de forma singular, decorrente da "aptidão [do estabelecimento] de produzir lucros",22. Tais conceitos, como não poderia deixar de ser, são aplicados nos casos de reorganização e liquidação das empresas, na íntegra.

Joaquin Bisbal Mendez resume de forma muito clara as empresas que devem ser submetidas à recuperação e, consequentemente, as que devem ser retiradas do mercado. Segundo ele,

A empresa deve ser reorganizada se existe a possibilidade de formular um plano, que respeitando alguns pontos de partida distributivos mínimos, permita deduzir

\footnotetext{
${ }^{19}$ PUGLIESI, Adriana Valéria. Direito Falimentar e Preservação da Empresa. São Paulo: Quartier Latin, 2.013 , p. 275.

${ }^{20}$ COELHO, Fábio Ulhoa. Comentários à Lei de Falências e de Recuperação de Empresas. $8^{\mathrm{a}}$ ed. São Paulo: Saraiva, 2.011, p. 173.

${ }^{21}$ BARRETO FILHO, Oscar. Teoria do Estabelecimento Comercial. São Paulo: Max Limonad, 1969, p. 75.

${ }^{22}$ BARRETO FILHO, Oscar. Idem, p. 169.
} 
um valor para a empresa em funcionamento ("going concern value") superior ao valor obtido com a liquidação da mesma ${ }^{23}$.

Ao se permitir que o devedor se recupere dos problemas econômicofinanceiros ainda mantendo a empresa em atividade, é possível garantir a satisfação dos interesses de credores, fornecedores, trabalhadores, dentre outros, mais interessados na permanência da relação econômica e/ou social com a empresa, do que com a imediata satisfação do seu crédito. Isto porque a manutenção da empresa em atividade pode aumentar as chances de recebimento integral de seus créditos - o valor da empresa em atividade, medido, entre outros meios, pelo fluxo de caixa descontado, pode vir a ser substancialmente maior que o valor da empresa para liquidação forçada, o que aumentaria as chances de recebimento integral do seu crédito. Em outras palavras, os bens organizados para o exercício da atividade empresarial adquirem um sobrevalor que, em geral, é perdido em caso de simples liquidação; e a restauração da empresa em crise econômico-financeira somente será possível com a ponderação dos interesses da empresa, dos trabalhadores e demais credores, em prol do benefício da coletividade ${ }^{24}$.

Neste sentido, Eduardo Goulart Pimenta ressalta que:

A restauração da empresa que passa por uma crise econômico-financeira somente será eficiente - e, portanto, viável - se todos estes grupos de interesses organizados vislumbrarem na manutenção da unidade produtiva o modo mais eficiente de maximizarem seus interesses. O credor somente orientará sua conduta no sentido da recuperação da unidade empresarial se perceber que esta é, se comparada ao fechamento do empreendimento e recebimento de seus direitos em concurso com os demais credores do falido, a escolha mais eficiente. ${ }^{25}$

23 Tradução livre de "La empresa debe ser reorganizada si existe la posibilidad de formular un plan, que respetando algunos puntos de partida distributivos mínimos, permita deducir un valor para la empresa en funcionamiento (going concern value) superior al valor obtenido con la liquidación de la misma." MENDEZ, Joaquin Bisbal. La empresa en crisis y el derecho de quiebras (Una aproximación económica y jurídica a los procedimientos de conservación de empresas). Bolonha: Real Colegio de España, 1.986, p. 78.

${ }^{24}$ Thomas H. Jackson vai ainda mais longe, e assevera que o Direito deve impor certos limites para o recebimento dos créditos, a fim de que os credores sejam "incentivados" a agir de forma cooperativa e coletiva. JACKSON, Thomas H. The logic and Limits of Bankruptcy Law. Washington, D.C.: BeardBooks, 1.986. p. 17.

${ }^{25}$ PIMENTA, Eduardo Goulart Recuperação de Empresas: um estudo sistematizado da nova lei de falências. $1^{\mathrm{a}}$ ed. São Paulo: IOB Thomson, 2.006, p. 76. 
É justamente neste novo cenário que o papel do administrador judicial ganha grande importância, tanto na recuperação judicial como na falência, já que não está presente apenas na recuperação extrajudicial e no acordo privado.

A figura do administrador judicial difere substancialmente do antigo comissário da concordata e do síndico da falência da LF, ainda que mantidas muitas das suas funções. Como bem anota Paulo Fernando Campos Salles de Toledo, "a alteração não se resumiu ao nome, uma vez que as atribuições e os requisitos para a sua escolha não são os mesmos dos antigos comissário e síndico"26. O administrador judicial não é mais escolhido entre os maiores credores (artigo 161, parágrafo $1^{\circ}$, inciso IV c/c artigo 60 da LF); sua escolha deve ser feita pelo magistrado, atendendo-se os pressupostos constantes do artigo 21 da LRE. O administrador judicial, seja pessoa física ou jurídica, deverá ser idôneo, tanto no âmbito moral como financeiro, e dotado de habilitação técnica e profissional necessária para a condução da empresa em crise, tanto para as hipóteses de sua recuperação, como para uma eficaz e rápida liquidação. Será ele diretamente responsável em fiscalizar as atividades do devedor em recuperação judicial e o cumprimento do plano judicial homologado; e assumirá a administração da massa falida, devendo maximizar os ativos, para a satisfação mais eficiente dos credores e também do falido.

As inovações trazidas pela LRE no tocante ao administrador judicial não são, todavia, isentas de problemas e lacunas que ainda não foram discutidas de forma suficiente e abrangente pela doutrina e pela jurisprudência pátrias ${ }^{27}$.

Passemos, então, a analisar nos próximos tópicos todos os enfoques dados a esta figura fundamental, tanto na recuperação judicial como na falência, não sem antes fazermos uma breve evolução histórica do administrador judicial e analisarmos sua natureza jurídica.

\footnotetext{
${ }^{26}$ TOLEDO, Paulo Fernando Campos Salles de. Recuperação judicial, a principal inovação da Lei de Recuperação de Empresas - LRE. In: A Nova Lei de Falências e de Recuperação de Empresas. Revista do Advogado, n. 83, São Paulo: AASP, 2.005, p. 104.

${ }^{27} \mathrm{Na}$ verdade, não é só a legislação atual que não trata de forma completa todos os aspectos referentes ao administrador judicial. Verificamos que muitas das lacunas e pontos polêmicos sempre existiram no direito falimentar. Neste sentido, confira-se VALVERDE, Trajano de Miranda. Comentários à Lei das Falências. (Decreto-lei $n^{o} 7.661$, de 21 de junho de 1945). Vol. I (art. $1^{\circ}$ a 51). $4^{\mathrm{a}}$ ed. rev. e atualizada por J. A. Penalva Santos e Paulo Penalva Santos. Rio de Janeiro: Revista Forense, 1.999, p. 440.
} 


\section{Breve análise histórica do administrador judicial na legislação.}

A origem da figura do administrador judicial remonta ao direito romano, com a instituição da "missio in bona" e da "cessio bonorum",28.

Através da "missio in bona", o devedor não perdia a propriedade de seus bens, apenas ficava despido de sua posse e administração, que passava a ser feita por um credor nomeado pelo magistrado, denominado "curator". O "curator" dava publicidade à "missio" para que outros credores pudessem vir a concorrer no prazo de 30 (trinta) dias. Decorrido tal período sem que o devedor tivesse quitado suas dívidas, o "curator" procedia à alienação do patrimônio para o melhor ofertante, com o intuito de pagar os credores em rateio $^{29}$.

Já pela “cessio bonorum”, criada pela "Lex Julia” em 737 a.C. ${ }^{30}$, o próprio devedor cedia seus bens a um credor, o qual poderia vendê-los por intermédio do “curator", para posterior pagamento de todos os credores de forma proporcional. Desta forma, ensina José Candido Sampaio de Lacerda, o devedor evitava a execução pessoal e a infâmia e também não seria mais sujeito novamente à execução, exceto por aquisição de novos bens ${ }^{31}$.

Vejamos como ocorreu a evolução da figura do hoje chamado administrador judicial na legislação pátria.

\footnotetext{
${ }^{28}$ REQUIÃO, Rubens. Curso de direito falimentar. Falência. $1^{\circ}$ Vol. $6^{\mathrm{a}}$ ed. São Paulo: Saraiva, 1981, p. 209/210.

${ }^{29}$ LACERDA, José Candido Sampaio de. Manual de direito falimentar. $14^{\mathrm{a}}$ ed. Atualizada por Jorge de Miranda Magalhães. Rio de Janeiro: Freitas Bastos, 1.999, p. 41.

${ }^{30}$ Amador Paes de Almeida, transcrevendo Waldemar Ferreira, destaca que na "Lex Julia" estaria o "embrião da falência": "Não poucos romanistas divisam na Lex Julia o assento do moderno Direito Falimentar, por ter editado os dois princípios fundamentais - o direito dos credores de disporem de todos os bens do devedor e da par condictio creditorum. Desde então, o credor, que tomava a iniciativa da execução, agia em seu nome e por direito próprio, mas também em benefício dos demais credores. Com isso, veio a formar-se o conceito de massa, ou seja, da massa falida." PAES DE ALMEIDA, Amador. Curso de Falência e Concordata. $18^{\mathrm{a}}$ ed. São Paulo: Saraiva, 2.000, p. 3-4.

${ }^{31}$ LACERDA, José Candido Sampaio de. Op. cit., p. 41.
} 


\subsection{Código Comercial de 1.850 (Lei 556 de .1.850).}

O primeiro diploma brasileiro que regulou o sistema falimentar foi o Código Comercial de 1.850 (Lei 556), em seus artigos 797 a 911, eis que até então a legislação portuguesa vigorava no País ${ }^{32}$.

Nos termos do artigo 797, a falência caracterizava-se pela cessação de pagamentos pelo comerciante.

Na sentença da abertura da quebra, o juiz designava "um ou mais" credores, que seriam "curadores fiscais provisórios", ou na sua inexistência, aquele que tivesse a “capacidade necessária" para assumir o cargo ${ }^{33}$. Como ressalta José Xavier Carvalho de Mendonça, em face da faculdade prevista neste dispositivo legal, geralmente se admitia a nomeação do promotor público ou de um advogado para ser "curador fiscal"34.

Os "curadores fiscais provisórios" atuavam na fase de instrução do processo, procedendo à arrecadação e ao inventário dos bens da massa ${ }^{35}$, além de acompanhar a avaliação dos mesmos, feita por avaliadores indicados por eles ${ }^{36}$. Eles eram obrigados a "praticar todos os atos necessários para conservação dos direitos e ações dos credores" 37 e deveriam continuar ou intentar todas as ações judiciais necessárias em nome da massa, desde que com prévia autorização judicial ${ }^{38}$. Eles recebiam “comissão" arbitrada pelo juiz, com base na "importância da massa, diligência, trabalho e responsabilidade" 39 .

Finda a instrução do feito, iniciava-se a fase de realização do ativo e de pagamento dos credores, com a convocação destes para deliberar sobre a concordata

\footnotetext{
${ }^{32}$ CEREZETTI, Sheila Christina Neder. A Recuperação Judicial de Sociedade por Ações. O Princípio da Preservação da Empresa na Lei de Recuperação e Falência. $1^{\mathrm{a}}$ ed. São Paulo: Malheiros, 2.012, p. 60.

${ }^{33}$ Art. 809, Lei 556/1.850.

34 CARVAlHO DE MENDONÇA, José Xavier. Tratado de Direito Comercial. Vol. VIII. $2^{\mathrm{a}}$. ed. Rio de Janeiro: Freitas Bastos, 1.962, p. 34.

${ }^{35}$ Art. 813, Lei 556/1.850.

${ }^{36}$ Art. 815, Lei 556/1.850.

${ }^{37}$ Art. 833, Lei 556/1.850.

${ }^{38}$ Art. 838, Lei 556/1.850.

${ }^{39}$ Art. 839, Lei 556/1.850.
} 
suspensiva, quando o falido assim propusesse, ou para formar o contrato de união e se proceder à nomeação de "administradores" 40 .

$\mathrm{Na}$ hipótese de ser aceita a concordata, os depositários eram obrigados a devolver ao devedor todos os bens que estavam em seu poder, e os curadores fiscais a prestar contas de sua administração ${ }^{41}$.

Em não havendo concordata, ficaria constituído o contrato de união entre os credores, no qual estes escolhiam entre si "um, dois ou mais administradores" para a administração da massa falida. Tal escolha era feita de preferência em "pessoa que seja credor comerciante, e cuja divida se ache verificada". Caso houvesse mais de um administrador, a responsabilidade era solidária ${ }^{42}$.

Esses "administradores" tinham poderes amplos para "praticar todos e quaisquer atos que necessários sejam a bem da massa, em Juízo e fora dele”, bem como para arrecadar, vender todos os bens da massa falida e pagar os credores, desde que a venda fosse feita em leilão público e precedida de autorização judicial ${ }^{43}$. Sua função acabava com a prestação de contas em reunião perante os credores e o juiz ${ }^{44}$.

A remuneração era arbitrada pelo Tribunal do Comércio, conforme a "importância da massa, e a diligência, trabalho responsabilidade" 45 .

\subsection{Decreto 917 de 1.890 .}

O Decreto 917, de 24 de outubro de 1.890, modificou em grande parte a estrutura da legislação falimentar, introduzindo meios preventivos à decretação da falência, quais sejam a concordata preventiva, o acordo extrajudicial, a cessão de bens e a moratória.

\footnotetext{
${ }^{40}$ Art. 842, Lei 556/1.850.

${ }^{41}$ Art. 854, Lei 556/1.850.

${ }^{42}$ Art. 856, Lei 556/1.850.

${ }^{43}$ Art. 856 e 862, Lei 556/1.850.

${ }^{44}$ Art. 868, Lei 556/1.850.

${ }^{45}$ Art. 839, Lei 556/1.850.
} 
Referido diploma legal alterou também o critério para caracterização do estado de falência de cessação do pagamento para a impontualidade e a realização de atos de falência ${ }^{46}$.

Os até então denominados "curadores fiscais provisórios" e "administradores" passam a ser chamados de "síndicos provisórios" e "síndicos definitivos", respectivamente.

Os síndicos eram sempre escolhidos entre as pessoas dos credores ou seus procuradores; apenas na falta delas, poderiam ser nomeadas pessoas estranhas ${ }^{47}$.

Na sentença que decretava a falência, eram nomeados pelo juiz "dois ou mais" síndicos provisórios, que arrecadavam os bens do falido, e administração da massa falida praticando, para tanto, todos os atos de gestão necessários ${ }^{48}$.

Caso não houvesse pedido de concordata ou ele fosse rejeitado, "dois ou mais" síndicos definitivos eram eleitos pelos credores, para a liquidação da massa, em virtude do contrato de união ${ }^{49}$.

Os síndicos eram responsáveis por dolo e $\operatorname{culpa}^{50}$ e estavam sujeitos à responsabilidade civil e criminal pelos atos por eles praticados, sendo equiparados para os efeitos penais aos funcionários públicos, em face de disposição expressa de lei ${ }^{51}$.

Sua remuneração era baseada na comissão marcada no edital do extinto Tribunal do Comercio de 5 de setembro de $1.855^{52}$.

Em ambas as fases, os síndicos eram acompanhados de perto pela figura então criada do Curador Fiscal de Massas Falidas.

\footnotetext{
${ }^{46}$ VALVERDE, Trajano de Miranda. Comentários à Lei das Falências. (Decreto-lei $n^{\circ} 7.661$, de 21 de junho de 1945). Vol. I (art. $1^{\circ}$ a 51). $4^{\mathrm{a}}$ ed. rev. e atualizada por J. A. Penalva Santos e Paulo Penalva Santos. Rio de Janeiro: Revista Forense, 1999, p. 18/19.

${ }^{47}$ Art. 148, § único, Decreto 917/1.890.

${ }^{48}$ Art. 6 e 36, Decreto 917/1.890.

${ }^{49}$ Art. 58, Decreto 917/1.890.

${ }^{50}$ Art. 36, §2 ${ }^{\circ}$, Decreto 917/1.890.

${ }^{51}$ Art. 85, Decreto 917/1.890.

${ }^{52}$ Art. 148, Decreto 917/1.890.
} 


\section{$2.3 \quad$ Lei 859 de 1.902 .}

Segundo Nelson Abrão, a Lei 859, promulgada em 16 de agosto de 1.902, “foi de consequências desastrosas no que concerne à escolha do administrador judicial" 53 .

O procedimento permanecia dividido em duas fases, continuando a segunda fase (de liquidação da massa falida) a ser exercida por "um ou mais" "síndicos definitivos, credores ou não, escolhidos pelos credores, com a constituição do contrato de união ${ }^{54}$.

O grande problema ocorreu na primeira fase do processo, com a instituição dos síndicos provisórios "oficiais" 55 . O síndico provisório era nomeado pelo juiz com base nas listas de comerciantes feitas bienalmente pelas juntas comerciais, com 40 (quarenta) nomes na Capital Federal, 16 (dezesseis) nas cidades de Belém, São Luiz, Fortaleza, Recife, Bahia, São Paulo e Porto Alegre, 10 (dez) nomes nas outras cidades com mais de 20.000 (vinte mil) habitantes, e 4 (quatro) a 8 (oito) nas demais. Nos estados desprovidos de junta comercial de acordo com lista formada pelos "comerciantes maiores contribuintes".

Não obstante a clareza da lei no sentido de que somente poderiam ser os síndicos os "comerciantes de fama ilibada, notoriamente abonados e que conheçam os negócios", o que se viu na prática foi um escândalo de grandes proporções, que ficou conhecido como "Ali babá e os 40 ladrões".

José Xavier Carvalho de Mendonça ressalta que "as juntas comerciais e os comerciantes nunca tomaram a serio essa valiosa atribuição que a lei lhes confiou, de organizar a lista. Nesta lista passaram a figurar pessoas de moralidade duvidosa e manifesta incapacidade, que procuravam um emprego, um meio de vida...". Por outro lado, prossegue o jurista, os juízes, por poderem escolher qualquer nome que figurasse na lista, nomeavam somente seus conhecidos; "os poucos comerciantes probos ali contemplados nunca tiveram a honra da nomeação judicial..." 56.

\footnotetext{
${ }^{53}$ ABRÃO, Nelson. O síndico na falência. $2^{a}$ ed. São Paulo: Liv. e Ed. Universitária de Direito, 1999, p. 102.

${ }^{54}$ Art. 66, Lei 859/1.902.

${ }^{55}$ Art.16, Lei 859/1.902.

${ }^{56}$ MENDONÇA, José Xavier Carvalho de. Tratado de Direito Comercial. Vol. VIII. $2^{\text {a }}$ ed. Rio de Janeiro: Freitas Bastos, 1962, p. 36.
} 
Não obstante os escândalos ocorridos, a responsabilidade dos síndicos estava prevista da mesma forma que na legislação anterior. Os síndicos eram responsáveis "por dolo e falta" e deveriam empregar toda a "diligência como se fora em seus próprios negócios" 57 . Juntamente com a comissão fiscal, eram sujeitos à responsabilidade civil e criminal. Eram equiparados aos funcionários públicos para fins penais ${ }^{58}$ e o julgamento das contas prestadas não os isentava das responsabilidades provenientes da administração da $\operatorname{massa}^{59}$.

A remuneração era arbitrada pelo juiz sobre o valor da liquidação em percentuais sobre os patamares estipulados no artigo 66, parágrafo $2^{\circ}$ do diploma legal.

\section{$2.4 \quad$ Lei 2.024 de 1.908.}

A Lei 2.024, de 17 de dezembro de 1.908, significou grande avanço para o sistema falimentar brasileiro, especialmente no tocante a evitar as fraudes perpetuadas sob a égide da legislação anterior, na administração dos bens da massa falida e na verificação e classificação dos créditos ${ }^{60}$, além de regular a concordata preventiva, dentre outros.

Face ao fracasso da escolha dos síndicos por listas oficiais, a lei voltou a adotar a forma de nomeação anterior, determinando que o juiz escolhesse o síndico dentre os credores. Entendia-se que os credores eram os maiores interessados na correta arrecadação, guarda e alienação da massa falida.

Para a primeira fase de administração e a arrecadação de bens da massa falida, bem como para proceder à verificação dos créditos, o juiz nomeava de "um ou três" síndicos, conforme a "importância" da massa ${ }^{61}$. Os síndicos eram escolhidos entre os credores do falido, de preferência os representantes de maior quantia, idôneos, residentes

\footnotetext{
${ }^{57}$ Art. $36, \S 5^{\circ}$, Lei 859/1.902.

${ }^{58}$ Art. 92, Lei 859/1.902.

${ }^{59}$ Art. 61, § único, Lei 859/1.902.

${ }^{60}$ CEREZETTI, Sheila Christina Neder. A Recuperação Judicial de Sociedade por Ações. O Princípio da Preservação da Empresa na Lei de Recuperação e Falência. $1^{a}$ ed. São Paulo: Malheiros, 2012, p. 70.

${ }^{61}$ Art. 64, Lei 2.024/1.908.
} 
ou domiciliados no foro da falência ${ }^{62}$. Apenas se o falido não apresentasse a relação de credores ou se nenhum destes aceitasse o cargo, o juiz poderia nomear pessoas estranhas à lide.

Os liquidatários, também em número de "um ou três", eram eleitos pelos credores na primeira assembleia, podendo recair a nomeação entre estes ou não, e também nos síndicos ${ }^{63}$. Eles passavam a substituir o sindico na administração da massa na hipótese de não ter sido apresentada ou ter sido rejeita proposta de concordata por parte do falido, quando da realização da primeira assembleia de credores ${ }^{64}$.

A lei descrevia como deveres comuns aos síndicos e liquidatários, dentre $\operatorname{outros}^{65}$ : i) a administração da massa; ii) dar maior publicidade à sentença de quebra e informar o horário de atendimento ao público interessado; iii) o recebimento de correspondência do falido; iv) a pratica de todos os atos de conservação de direitos e ações; v) a representação da massa de credores em juízo; vi) o fornecimento das informações e documentos necessários, bem como a sua obtenção com os credores e prepostos do falido; vii) a escolha de avaliadores, contadores e demais auxiliares, quando necessário.

Aos síndicos competia, em especial: i) a arrecadação dos bens do falido; ii) a verificação e classificação dos créditos, para posterior decisão do juiz; iii) o levantamento ou verificação e correção do balanço apresentado pelo falido; iv) a apresentação na primeira assembleia de credores do relatório circunstanciado sobre as causas da falência, o valor estimado do ativo e passivo, os atos praticados pelo devedor e puníveis civil e criminalmente; v) a entrega, em 24 horas, aos liquidatários ou ao devedor concordatário de todos os bens da massa em seu poder, sob pena de prisão ${ }^{66}$.

Já aos liquidatários cabia, basicamente e de forma exclusiva: i) a arrecadação dos bens adquiridos durante a falência ou que, eventualmente, não tenham sido

\footnotetext{
${ }^{62}$ Art. $64, \S 1^{\circ}$, Lei 2.024/1.908.

${ }^{63}$ Art. 66, Lei 2.024/1.908.

${ }^{64}$ Art. $102, \$ 3^{\circ}$, Lei $2.024 / 1.908$.

${ }^{65}$ Art. 65 e 67, Lei 2.204/1.908.

${ }^{66}$ Art. 65, Lei 2.024/1.908
} 
arrecadados pelos síndicos; e ii) a realização do ativo e liquidação do passivo, com a apresentação de contas mensais de liquidação ${ }^{67}$.

A remuneração continuava a ser feita da mesma forma já prevista na lei anterior.

No tocante à responsabilidade, os síndicos e liquidatários respondiam civilmente por "má administração, desídia, negligência, abuso, má fé ou infração à lei ${ }^{68}$. E, como no diploma anterior, eram equiparados aos funcionários públicos, para fins penais ${ }^{69}$.

\subsection{Decreto 5.746 de 1.929 .}

O Decreto 5.746, de 09 de dezembro de 1.929, manteve basicamente o sistema anterior no que diz respeito ao sindico e aos liquidatários, com poucas alterações.

Tal diploma legal reduziu para um único "síndico" nomeado pelo juiz na sentença declaratória da falência, para administrar a massa, inventariar os bens e proceder aos trabalhos de verificação de créditos (que, posteriormente, seriam analisados pelo juiz). Ele era escolhido entre os credores do falido, residentes ou domiciliados no foro da falência e deveriam ter idoneidade moral e financeira reconhecida. Somente na hipótese de nenhum credor aceitar o cargo, o juiz poderia nomear pessoas estranhas à lide, desde que "idôneas e de boa fama" 70 .

Na primeira assembleia de credores ${ }^{71}$, estes escolhiam um "liquidatário", que deveria atender igualmente aos critérios de escolha do sindico, para a administração, realização e liquidação do ativo ${ }^{72}$.

\footnotetext{
${ }^{67}$ Art. 67, Lei 2.024/1.908.

${ }^{68}$ Art. 72, caput. Lei 2.024/1.908.

${ }^{69}$ Art. 172, §2 ${ }^{\circ}$, Lei 2.024/1.908.

${ }^{70}$ Art. 64, Decreto 5.746/1.929.

${ }^{71}$ Art. 102, Decreto 5.746/1.929.

${ }^{72}$ Art. 66, Decreto 5.746/1.929.
} 
Nelson Abrão destaca que pela falta de motivação financeira, em muitos casos, os credores declinavam do cargo, o que fazia com que a escolha recaísse em "reduzido círculo de pessoas do conhecimento do magistrado", o que resultava, citando Trajano de Miranda Valverde, "em proteção de meia dúzia de causídicos"

Responsabilidade $^{74}$ e remuneração ${ }^{75}$ continuam reguladas nos mesmos termos que a Lei 2.024/08.

\subsection{Decreto-lei 7.661 de 1.945.}

O Decreto-lei 7.661, de 21 de junho de 1945, diminuiu a influência dos credores nas decisões a respeito do destino do devedor, tendo praticamente acabado com a importância da assembleia de credores e transferindo para o magistrado poderes mais $\operatorname{amplos}^{76}$.

A concordata, por exemplo, deixou de ser um "contrato" marcado pela aceitação dos maiores credores, para se tornar um benefício legal, de cunho nitidamente processual, a ser concedido única e exclusivamente pelo juiz ${ }^{77}$, desde que cumpridos os requisitos formais estabelecidos em lei.

A LF também acabou com a figura do "liquidatário" e instituiu a do "comissário" para a concordata e a do "síndico" para a falência.

A escolha do comissário e do síndico era feita exclusivamente pelo juiz, dentre os maiores credores, residentes ou domiciliados no foro da falência, de reconhecida

\footnotetext{
${ }^{73}$ ABRÃO, Nelson. O síndico na falência. $2^{\text {a }}$ ed. São Paulo: Liv. e Ed. Universitária de Direito, 1999, p. 104. ${ }^{74}$ Art. 72 e $173, \S 2^{\circ}$, Decreto 5.746/1.929.

${ }^{75}$ Art. 73, Decreto 5.746/1.929.

${ }^{76}$ Trajano de Miranda Valverde confirma que a LF deu aos juízes "atribuições delicadas e poderes amplos, com duplo objetivo: o de resolver, honestamente, o conflito de interesses individuais e o de preservar a empresa mercantil contra a ameaça de sua destruição". VALVERDE, Trajano de Miranda. Comentários à Lei das Falências. (Decreto-lei $n^{o}$ 7.661, de 21 de junho de 1945). Vol. II (art. 62 a 176). $4^{\mathrm{a}}$ ed. rev. e atualizada por J. A. Penalva Santos e Paulo Penalva Santos. Rio de Janeiro: Revista Forense, 1.999, p. 238.

${ }_{77}$ Aos credores cabia apenas a oposição de embargos à concordata, nos termos dos art. 142 e 143 da lei.
} 
idoneidade moral e financeira ${ }^{78}$. Caso os 3 (três) credores sucessivamente nomeados recusassem o cargo, o juiz poderia nomear "pessoa estranha, idônea e de boa fama, de preferência comerciante" ${ }^{79}$. Na hipótese de ser decretada a falência durante o curso da concordata, o juiz nomeava síndico o até então comissário, salvo se houvesse motivos para afastá-lo do cargo ${ }^{80}$.

O grande problema que se verificava, na prática, no que pertine à nomeação do comissário e do síndico entre os maiores credores, consistia no fato de que, na maioria dos casos, na concordata o empresário não apresentava a relação completa de credores (não obstante a obrigação legal de fazê-lo, cf. artigo 159, parágrafo $1^{\circ}$, inciso VI da LF) e não raro poderia apresentar nomes de falsos credores, na verdade seus conhecidos, justamente com o intuito de serem escolhidos para a nomeação ${ }^{81}$. Já na falência, os credores ainda não eram nem sequer conhecidos, haja vista que as habilitações de crédito logicamente somente eram recebidas após decretação da sentença de quebra, na qual já deveria nomear o síndico ${ }^{82}$.

A falta de interesse dos credores em assumir tal encargo também representava outro grande obstáculo para a nomeação. A grande maioria dos credores geralmente eram, como ainda de fato são, instituições financeiras ou sociedades empresárias, cujo objetivo social em nada coincidia com as funções que deveriam ser desempenhadas como comissárias ou sindicas de massa falida. Acresça-se a isso, as responsabilidades que decorriam do cargo e a baixa remuneração após muitos anos de trabalho, principalmente na grande parte das falências.

Esses entraves faziam com que, em muitos processos senão na sua maioria, os juízes nomeassem advogados dativos de sua confiança, acabando por alterar a intenção da

\footnotetext{
${ }^{78}$ Art. 161 e 60, Decreto-Lei 7.661/1.945.

${ }^{79}$ Art. 60, § 20 , Decreto-Lei 7.661/1.945.

${ }^{80}$ Art. 162, inc. I, § $2^{\circ}$, Decreto-Lei 7.661/1.945.

81 Neste sentido, vide Waldemar Ferreira: "Não poucas vezes organizam devedores listas de credores, mencionando entre os maiores seus comparsas, simulados detentores de cambiais adrede preparadas por aqueles. Nas comarcas de movimento judiciário intenso, o desconhecimento, pelos juízes, dos nomes dos credores, leva-os a confiar nas referencias de escrivães, e até de auxiliarias de cartórios, às vezes mancomunados com os falidos.”. FERREIRA, Waldemar. Tratado de Direito Comercial. Vol. 15. São Paulo: Saraiva, 1966, p. 7.

${ }^{82}$ Art. 80, Decreto-Lei 7.661/1.945.
} 
lei de deixar aos credores tais encargos, os quais se acreditava que, pela importância de seus créditos, seriam os maiores interessados na boa condução e deslinde do feito ${ }^{83}$.

Nelson Abrão destaca que a "proliferação da sindicância dativa" e o "peso da influência que governa a nomeação" em nada contribuíam para que as figuras do comissário e do síndico tivessem as qualidades necessárias ao cargo - "capacidade, ilibada reputação e interesse exemplar na solução do litígio" ${ }^{84}$. De fato, ao discorrer sobre o diploma de 1.945 e confrontá-lo com o direito comparado, Nelson Abrão já apontava para a necessidade de profissionalização da atividade do síndico, dotado de uma equipe técnica, sob pena de "dissipação patrimonial e postergação das fases do procedimento" ${ }^{85}$.

Na concordata, o concordatário conservava a plena administração de seus bens e gerência dos negócios ${ }^{86}$. O comissário apenas fiscalizava as atividades do empresário, com suas funções detalhadas no artigo 169 da LF; cabia àquele também a elaboração do quadro geral de credores, para posterior homologação judicial ${ }^{87}$.

O síndico, por sua vez, era nomeado na sentença que decretava a falência (ou na sentença que convolava a concordata em quebra, que, geralmente, designava o comissário para a sindicatura), cujas funções eram de verdadeira administração da massa falida até a liquidação de todos os bens e direitos e pagamento do passivo ${ }^{88}$.

A remuneração do síndico e do comissário era feita de acordo com a "sua diligência, ao trabalho e à responsabilidade da função e à importância da massa" e com base nos patamares e porcentagens, estipulados na LF. No caso de concordata, calculava-se o valor sobre a quantia a ser paga aos credores quirografários (posto que a concordata só alcançava tais créditos) e era limitada à terça parte das porcentagens previstas no artigo 67

\footnotetext{
${ }^{83}$ Júlio Kahan Mandel ressalta que: "Outro motivo da nomeação de advogados dativos para exercerem o cargo de síndico era o desinteresse dos principais credores. Nenhum empresário investe dinheiro zelando pela boa liquidação do processo se sabe que não irá se beneficiar disso. E ser síndico gerava trabalho, custos e responsabilidade. Isso acontecia porque os credores constatavam que, após o pagamento do passivo trabalhista, o dinheiro restante serviria somente para o pagamento das dívidas tributárias. O credor teria de trabalhar sem receber seu crédito e até mesmo sem receber a remuneração pelo exercício do cargo." MANDEL, Julio Kahan. Nova Lei de Falências e Recuperação de Empresas anotada. Lei n. 11.101, de 9 de fevereiro de 2005. $1^{\text {a }}$ ed. São Paulo: Saraiva, 2.005, p. 46.

${ }^{84}$ ABRÃO, Nelson. O síndico na falência. $2^{\mathrm{a}}$ ed. São Paulo: Liv. e Ed. Universitária de Direito, 1999, p. 107.

${ }^{85}$ ABRÃO, Nelson. Idem, ibidem.

${ }^{86}$ Art. 167, Decreto-Lei 7.661/1.945.

${ }^{87}$ Art. $173, \S 4^{\circ}$, Decreto-Lei 7.661/1.945.

${ }^{88}$ Art. 63 e ss, Decreto-Lei 7.661/1.945.
} 
da lei ${ }^{89}$. Para os síndicos, o cálculo recaia sobre o produto dos bens ou valores da massa, vendidos ou liquidados, nas porcentagens e patamares previstos no citado artigo $67^{90}{ }^{91}$.

Note-se que com o passar dos anos, o critério de remuneração foi sendo alterado pela jurisprudência pátria, em face da desvalorização da moeda, admitindo-se o pagamento calculado em outros patamares e em porcentagens maiores que as previstas em lei, tomando-se como critério primordial o trabalho desenvolvido e o tempo despendido pelo síndico/comissário ${ }^{92}{ }_{-}{ }_{-}{ }_{-} 94$.

O problema com a remuneração não se esgotava na forma de sua apuração. Pela LF, o pagamento do síndico deveria ocorrer somente após a liquidação da massa e pagamento dos credores trabalhistas, o que, em inúmeras vezes, implicava no não recebimento da remuneração devida pela simples falta de recursos da massa. Por tais motivos, a jurisprudência alterou a ordem legal prevista, determinando que a remuneração do síndico gozava do mesmo privilégio dos créditos trabalhistas, razão pela qual deveria

${ }^{89}$ Art. 170, Decreto-Lei 7.661/1.945.

${ }^{90}$ Art. 67. O síndico tem direito a uma remuneração, que o juiz deve arbitrar, atendendo à sua diligência, ao trabalho e à responsabilidade da função e à importância da massa, mas sem ultrapassar de $6 \%$ até Cr\$100.000,00; de 5\% sobre o excedente até Cr\$200.000,00; de 4\% sobre o excedente até Cr\$500.000,00; de $3 \%$ sobre o excedente até $\mathrm{Cr} \$ 1.000 .000,00$; de $2 \%$ sobre o que exceder de $\mathrm{Cr} \$ 1.000 .000,00$.

$\S 1^{\circ}$ A remuneração é calculada sobre o produto dos bens ou valores da massa, vendidos ou liquidados pelo síndico. Em relação aos bens que constituir em objeto de garantia real, o síndico perceberá comissão igual a que, em conformidade com a lei, for devida ao depositário nas execuções judiciais.

$\S 2^{\circ}$ No caso de concordata, a percentagem não pode exceder a metade das taxas estabelecidas neste artigo, e é calculada sòmente sobre a quantia a ser paga aos credores quirografários.

$\S 3^{\circ}$ A remuneração será paga ao síndico depois de julgadas suas contas.

$4^{\circ}$ Não cabe remuneração alguma ao síndico nomeado contra as disposições desta lei, ou que haja renunciado ou sido destituído, ou cujas contas não tenham sido julgadas boas.

$5^{\circ}$ Do despacho que arbitrar a remuneração cabe agravo de instrumento, interposto pelo síndico, credores ou falido.

${ }^{91}$ Trajano de Miranda Valverde destaca que a lei anterior revogada era mais criteriosa pois "ordenava que a percentagem fosse calculada sobre o liquido efetivamente apurado a final, deduzidas as despesas da liquidação." VALVERDE, Trajano de Miranda. Comentários à Lei das Falências. (Decreto-lei no 7.661, de 21 de junho de 1945). Vol. II (art. 62 a 176). $4^{\text {a }}$ ed. rev. e atualizada por J. A. Penalva Santos e Paulo Penalva Santos. Rio de Janeiro: Revista Forense, 1.999, p. 10. (g/n)

92 "Agravo de instrumento. Decisão que fixou honorários do síndico da falência em 6\% - Atuação que durou 22 anos e resultou em superávit. Valor irrisório. Aumento para 20\% - Dado provimento ao recurso" (TJSP, AI n. 0108768-69.2013.8.26.0000, Rel. Des. Lucila Toledo, 9a Câmara de Direito Privado, j. 03/12/13, v.u.).

93 "FALÊNCIA - Síndico - Remuneração - Inaplicabilidade pura e simples das percentagens previstas no art. 67 da LF - Majoração concedida - Recurso provido, em parte, para esse fim. (Agravo de Instrumento n. 278.984 - TJSP, 3 a Câmara Civil, j. 26/02/80, v.u.)”. In: Revista de Jurisprudência do Tribunal de Justiça do Estado de São Paulo, vol. 62, São Paulo: Lex Editora, 1980, p. 256/257.

94 “EMENTA - FALÊNCIA - HONORÁRIOS DO SÍNDICO - A remuneração segundo o artigo 67, § $1^{\circ}$, do Decreto-lei 7.661/45 é de difícil aplicação, pois se refere a padrão monetário diverso do atual, o que confere certa discricionariedade ao Juiz para sua fixação - Valor exíguo - Necessário que o valor fixado seja proporcional ao zelo e dedicação do Síndico da Massa Falida - Prudente que se fixe tal verba em 6\% sobre o produto dos bens da massa falida - Decisão reformada - Recurso provido" (TJSP, AI n. 420.623.4/0-00, Rel. Des. Sales Rossi, $8^{\text {a }}$ Câmara de Direito Privado, j. 30/03/06, v.u.). 
ser pago na mesma oportunidade e proporcionalmente, dividindo-se o produto da arrecadação do ativo dentro da classe respectiva entre os credores habilitados. Esse entendimento culminou na Súmula n. 219 do Superior Tribunal de Justiça, editada em 10 de março de $1999^{95}$; e, justamente para não desestimular o exercício do encargo, os tribunais também acabaram por aceitar que a remuneração fosse feita de forma mensal, para suas despesas e manutenção, descontando-se, ao final do processo falimentar, os valores recebidos ${ }^{96}$.

O síndico respondia pelos prejuízos causados à massa, por sua má administração ou por infração a qualquer disposição da LF. A LF era expressa no sentido de que a autorização do juiz ou o julgamento das suas contas, não isentavam o síndico e o comissário da responsabilidade civil e penal, quando ele não ignorasse o prejuízo que do seu ato pudesse resultar para a massa ou quando infringir disposição da lei ${ }^{97}$.

\footnotetext{
${ }^{95}$ Súmula n. 219 do Superior Tribunal de Justiça: "Os créditos decorrentes de serviços prestados à massa falida, inclusive a remuneração do síndico, gozam dos privilégios próprios dos trabalhistas." DJ 25.03.1.999. ${ }^{96}$ EMENTA: RECURSO ESPECIAL - COMERCIAL - ART. 212 DO DECRETO-LEI N. 7.661/45 HONORÁRIOS DO PERITO CONTADOR - COMPATIBILIDADE COM O SERVIÇO A SER REALIZADO - FUNDAMENTO AUTÔNOMO - AUSÊNCIA DE IMPUGNAÇÃO ESPECÍFICA APLICAÇÃO DA SÚMULA N. 283/STF - FALÊNCIA - SÍNDICO - AUXILIAR DO JUÍZO REMUNERAÇÃO MENSAL - POSSIBILIDADE - ENCARGO DA MASSA FALIDA - DESCONTO, AO FINAL DO PROCESSO FALIMENTAR, DOS VALORES RECEBIDOS - NECESSIDADE - ATIVIDADE DE SINDICATURA - PRESERVAÇÃO - INTERESSE DOS CREDORES - RECURSO ESPECIAL PARCIALMENTE CONHECIDO E, NESSA PARTE, IMPROVIDO. I - Ausência de impugnação a fundamento por si só suficiente para manter o acórdão, qual seja, a compatibilidade da remuneração do contador ao serviço prestado. Incidência da Súmula n. ${ }^{\circ}$ 283-STF. II - O síndico, assim como seu sucedâneo administrador judicial - não exerce profissão. Suas atividades possuem natureza jurídica de órgão auxiliar do Juízo, cumprindo verdadeiro múnus público, não se limitando a representar o falido ou mesmo seus credores. Cabe-lhe, desse modo, efetivamente, colaborar com a administração da Justiça. III - Os honorários do síndico constituem encargo da massa falida e, por isso, podem ser pagos ao síndico mensalmente, para suas despesas e manutenção, descontando-se, ao final do processo falimentar, os valores recebidos observando-se os índices previstos no art. 67 da antiga Lei de Falências. IV - Os interesses dos credores, em razão da atividade diligente do síndico, estarão preservados na medida em que se evitará a dilapidação do patrimônio da massa falida e se identificará eventual irregularidade que possa ocorrer no curso do processo falimentar, o que justifica sua remuneração mensal. VII - Recurso especial parcialmente conhecido e, nessa parte, improvido. (STJ - REsp: 1032960 PR 2008/0036352-7, Rel. Min. Massami Uyeda, $3^{a}$ Turma, j. 01/06/2.010).

${ }^{97}$ Art. 68, Decreto-Lei 7.666/1.945.
} 


\section{O administrador judicial.}

\subsection{Natureza jurídica.}

Apesar das diversas alterações legislativas ocorridas, permanecem incólumes os ensinamentos de Trajano de Miranda Valverde que, ao comentar a LF, reuniu as diversas teorias formuladas sobre a natureza jurídica dos administradores da massa falida em dois grupos: a teoria da representação e a teoria do ofício ou da função judiciária ${ }^{98}$.

\subsubsection{Teoria da representação.}

Na teoria da representação, não há consenso sobre quem o administrador judicial representa. Segundo Trajano de Miranda Valverde, de acordo com alguns autores, ele representa o falido. Já para outros, o administrador judicial é o representante legal do titular do patrimônio separado, representando-o somente nessa qualidade, e não a completa personalidade do falido. Há também o entendimento no sentido de que ele representa o falido e os credores, ora o primeiro, ora estes, ou, ainda, ambos e a lei. Outros, por sua vez, enxergam o administrador como um órgão da massa dos credores que, desse modo, passaria a ser uma pessoa jurídica, isto é, passaria a ser titular de direitos e obrigações diversos dos credores. Outras posições entendem ser o administrador órgão da massa dos credores na sua unidade ou um mandatário judicial, representante da massa dos credores e só acessoriamente do falido. Também se sustenta que a sentença que declara a falência faria surgir um ente jurídico capaz de adquirir e exercer direitos e contrair obrigações e que teria no administrador a figura do seu representante ${ }^{99}$.

A teoria da representação, em qualquer de suas vertentes, traz muitas dificuldades para sua aceitação, sendo, portanto, altamente discutível. Primeiro porque a representação do falido pelo administrador não seria, obviamente, voluntária, mas sim legal, estando, nesta situação, na mesma categoria do titular do pátrio poder. Todavia, a

${ }^{98}$ VALVERDE, Trajano de Miranda. Comentários à Lei das Falências. (Decreto-lei $n^{\circ} 7.661$, de 21 de junho de 1945). Vol. I (arts. $1^{\mathrm{o}}$ a 61). $4^{\mathrm{a}}$ ed. rev. e atualizada por J. A. Penalva Santos e Paulo Penalva Santos. Rio de Janeiro: Revista Forense, Rio de Janeiro: Revista Forense, 1999, p. 441-448.

${ }^{99}$ VALVERDE, Trajano de Miranda. Idem, p. 441. 
representação legal contém, de forma indissociável, a ideia de proteção dos interesses do representado, o que não ocorre no caso em questão. Como poderia o administrador representar o falido, mas agir no interesse da massa, e atuar, em muitas ocasiões, contrariamente ao interesse do representado? ${ }^{100}$

Trajano de Miranda Valverde explica que seria difícil sustentar a representação da coletividade dos credores, já que seria esta elevada a categoria de pessoa jurídica, dotada de direitos e deveres, ficção que não encontraria amparo na realidade e que importaria "a transformação de um objeto de direito, como é o patrimônio autônomo e separado, em sujeito de direito ${ }^{101}$. $\mathrm{O}$ administrador judicial apenas administra o patrimônio falido, mas o titular desse patrimônio continua a ser o falido, que perde a posse direta mas continua responsável pelas obrigações que os oneram. $\mathrm{O}$ sujeito ativo e passivo das relações jurídicas que formam esse patrimônio continua a ser o falido, não havendo, pois, como convertê-lo (o patrimônio) em pessoa jurídica ${ }^{102}$. Concluindo, Trajano de Miranda Valverde assevera que:

Na falência não há nem personalidade, nem representação. O administrador não representa nem o devedor, nem a massa de credores, nem a massa falida, que não constitui pessoa jurídica. Não há representação voluntária, e a representação legal é inconcebível, porque o administrador não tutela o interesse egoístico deste ou daquele, mas age no interesse objetivo da justiça, eventualmente, contra o interesse pessoal do falido ou contra o interesse dos credores. ${ }^{103}$

Não obstante discordarmos da teoria da representação, não podemos deixar de destacar que o entendimento no sentido de que a massa falida não poderia ser sujeito de direitos e obrigações foi alterado com o passar no tempo, não havendo mais discussão sobre a possibilidade de representação de entes desprovidos de personalidade jurídica, como ocorre com os condomínios, fundos de investimentos, etc.

\footnotetext{
${ }^{100}$ VALVERDE, Trajano de Miranda. Comentários à Lei das Falências. (Decreto-lei $n^{\circ} 7.661$, de 21 de junho de 1945). Vol. I (arts. $1^{\circ}$ a 61). $4^{\text {a }}$ ed. rev. e atualizada por J. A. Penalva Santos e Paulo Penalva Santos. Rio de Janeiro: Revista Forense, 1.999, p. 442.

${ }^{101}$ VALVERDE, Trajano de Miranda. Idem, p. 444.

${ }^{102}$ Este também é o entendimento de Francisco Cavalcanti Pontes de Miranda: "Na massa falida não há personalidade; portanto, não há representação. Não se pode pensar em representação voluntária, nem em representação legal.” PONTES DE MIRANDA, Francisco Cavalcanti. Tratado de Direito Privado. Parte Especial. Tomo XXIX. Direito das Obrigações. Atualizado por Manuel Justino Bezerra Filho. São Paulo: Revista dos Tribunais, 2.012, p. 59.

${ }^{103}$ VALVERDE, Trajano de Miranda. Op. cit., p. 444.
} 
Fabio Ulhoa Coelho destaca que os sujeitos de direito podem ser dotados de personalidade jurídica ou não ${ }^{104}$. No primeiro caso, eles podem praticar todo e qualquer ato e/ou negócio jurídico; já os desprovidos de personalidade jurídica podem "praticar apenas os atos inerentes à sua finalidade (se possuírem uma) ou para os quais estejam especificamente autorizados". A massa falida "está autorizada a praticar todos os atos úteis à administração dos bens arrecadados do empresário falido", além de ser "titular de créditos do falido, podendo cobrar os devedores inadimplentes", sucedê-lo nas obrigações e substituí-lo em todas as ações judiciais de que era parte ${ }^{105}$.

Como ressalta Paulo Fernando Campos Salles de Toledo, além de no plano processual a massa falida poder situar-se no polo ativo da relação jurídica, em várias situações jurídicas assume a posição de verdadeiro sujeito de direito. Para tanto, exemplifica com duas situações previstas na lei: o administrador judicial pode transigir sobre dívidas e negócios da massa ${ }^{106}$ e pode executar os contratos bilaterais originalmente firmados pelo falido ${ }^{107}$. Por outro lado, esclarece que a qualificação da massa falida, como um centro de interesses diversos, "a aproxima, até certo ponto, da pessoa jurídica", restando "admitir, pelo menos, a ocorrência da aludida personalidade natural", como ocorre com as sociedades de fato ou irregulares, "até que o Direito reconheça a jurídica" 108.

\subsubsection{Teoria do ofício ou da função judiciária.}

A teoria do oficio ou da função judiciária tem maior aceitação e prevalece no direito pátrio ${ }^{109}{ }_{-}^{110}$.

\footnotetext{
${ }^{104}$ COELHO, Fábio Ulhoa. Curso de Direito Civil, vol. 1. São Paulo: Saraiva. 2.003, p. 139.

${ }^{105}$ COELHO, Fábio Ulhoa. Idem, p. 154.

${ }^{106}$ Art. 22, § $3^{\circ}$, LRE.

${ }^{107}$ Art. 117, "caput", LRE.

${ }^{108}$ TOLEDO, Paulo Fernando Campos Salles de. Da personificação da massa falida. In: Revista de Direito Mercantil, vol. 78. São Paulo: Revista dos Tribunais, 1.990, p.49.

${ }^{109}$ VALVERDE, Trajano de Miranda. Comentários à Lei das Falências. (Decreto-lei n $n^{\circ} 7.661$, de 21 de junho de 1945). Vol. I (arts. $1^{\circ}$ a 61). $4^{\mathrm{a}}$ ed. rev. e atualizada por J. A. Penalva Santos e Paulo Penalva Santos. Rio de Janeiro: Revista Forense, 1.999, p. 444-448. TOLEDO, Paulo Fernando Campos Salles de. In: TOLEDO, Paulo Fernando Campos Salles de, e ABRÃO, Carlos Henrique (coord.). Comentários à Lei de Recuperação de Empresas e Falência. 4a . ed. São Paulo: Saraiva, 2.010, p. 107. VERÇOSA, Haroldo Malheiros Duclerc. In: SOUZA JUNIOR, Francisco Satiro de, e PITOMBO, Antônio Sérgio de A. Moraes. (coord.). Comentários à Lei de Recuperação de Empresas e Falência. Lei 11.101/2005. - Artigo por Artigo. 2 2a ed. São Paulo:
} 
Nos dizeres de Trajano Miranda Valverde, o administrador judicial é "órgão criado pela lei para auxiliar a justiça na realização de seu objetivo"111_112_113. Ele "não representa quem quer se seja, mas cumpre os deveres inerentes ao cargo" e é por esta razão que "pode agir contra ou a favor do falido, contra ou a favor das pretensões dos credores concorrentes" $^{\text {"114 }}$, sempre nos termos da lei.

Renzo Provinciali esclarece que, sob o aspecto processual, o conceito de órgão é contraposto ao de parte porque enquanto "as partes são os sujeitos do processo (na falência, o devedor falido e os credores), os órgãos (pessoas físicas que o compõem) constituem os instrumentos pelos quais o processo e opera e se desenvolve" ${ }^{\text {115 }}$. E, ao tratar especificamente do "curatore" ressalta que é um órgão próprio da execução falimentar, sendo auxiliar da Justiça ${ }^{116}$.

Revista dos Tribunais, 2.007, p. 165. REQUIÃO, Rubens. Curso de direito falimentar. Falência. $1^{\mathrm{o}}$ Vol. $6^{\mathrm{a}}$ ed. São Paulo: Saraiva, 1.981, p. 212/213. PONTES DE MIRANDA, Francisco Cavalcanti. Tratado de Direito Privado. Parte Especial. Tomo XXIX. Direito das Obrigações. Atualizado por Manuel Justino Bezerra Filho. São Paulo: Revista dos Tribunais, 2.012, p. 56-58. DINAMARCO, Candido Rangel. Instituições de Direito Processual Civil. Vol I. 4a ed. São Paulo: Malheiros, 2.004, p. 648-649 e 672. ABRÃO, Nelson. O síndico na falência. $2^{\mathrm{a}}$ ed. São Paulo: Liv. e Ed. Universitária de Direito, 1.999, p. 105. COELHO, Fábio Ulhoa. Comentários à Lei de Falências e de Recuperação de Empresas. $8^{\text {a }}$ ed. São Paulo: Saraiva, 2.011, p. 109.

${ }^{110}$ Este também é o entendimento da jurisprudência pátria: STJ, REsp 1.324.837/SP, Rel. Min. Maria Isabel Gallotti, 4a . Turma, j. 11/12/2012, v.u.: “(...) o síndico exerce munus público, de modo que sua atividade vai além de mero administrador ou representante da massa, possuindo mesmo natureza de órgão auxiliar do juízo (...)”; STJ, REsp 1032960/PR, Rel. Min. Massami Uyeda, 33. Turma, j. 01/06/2010, v.u.: “(...) II - O síndico, assim como seu sucedâneo - administrador judicial - não exerce profissão. Suas atividades possuem natureza jurídica de órgão auxiliar do Juízo, cumprindo verdadeiro múnus público, não se limitando a representar o falido ou mesmo seus credores. Cabe-lhe, desse modo, efetivamente, colaborar com a administração da Justiça. (...)".

${ }^{111}$ VALVERDE, Trajano de Miranda. Comentários à Lei das Falências. (Decreto-lei $n^{\circ} 7.661$, de 21 de junho de 1945). Vol. I (arts. $1^{\text {o }}$ a 61). $4^{\mathrm{a}}$ ed. rev. e atualizada por J. A. Penalva Santos e Paulo Penalva Santos. Rio de Janeiro: Revista Forense, 1.999, p. 446.

112 Erasmo Valladão Azevedo e Novaes França, lembrando as lições de Francesco Carnelutti, lembra que a "idéia de órgão está vinculada à de interesse comum ou coletivo". FRANCA, Erasmo Valladão Azevedo e Novaes. In: SOUZA JUNIOR, Francisco Satiro de, e PITOMBO, Antônio Sérgio de A. Moraes. (coord.). Comentários à Lei de Recuperação de Empresas e Falência. Lei 11.101/2005. - Artigo por Artigo. $2^{\mathrm{a}}$ ed. São Paulo: Revista dos Tribunais, 2.007, p. 203.

${ }^{113}$ Segundo De Plácido e Silva, órgão é "o instrumento, a que se comete o desempenho de uma função determinada (...) exprime a ideia de executor ou realizador, porque por ele se executam ou se realizam as finalidades ou objetivos atribuídos à organização, ou se desempenham as funções que lhe são inerentes." SILVA, De Plácido e. Vocabulário Jurídico. 11ª ed. Rio de Janeiro: Forense, 1.989, p. 294.

${ }^{114}$ VALVERDE, Trajano de Miranda. Op. cit., p. 447.

115 Tradução livre de "le parti sono i soggetti del processo (nel fallimento, il debitore fallito e i creditori); gli organi (persone fisiche a ciò preposte) costituiscono gli strumenti mediante i quali il processo opera e si svolge". PROVINCIALI, Renzo. Trattado di Diritto Fallimentare. Vol. I. Milão, Dott. A. Giuffrè Editore, 1.974, p.659.

${ }^{116}$ PROVINCIALI, Renzo. Idem, p.696. 
Já Nelson Abrão conclui que o administrador judicial é o órgão auxiliar da justiça, o qual permanece equidistante às disputas das partes, "servindo primacialmente aos interesses da Justiça"117.

Dessarte, o administrador judicial auxilia o juízo a atingir os fins previstos na lei e não figura como representante dos credores ou do devedor; na verdade, ele atua em benefício do procedimento de reorganização ou liquidação. Nos termos da LRE, o administrador judicial age, na falência, sempre visando à otimização dos ativos e auxiliando na rápida retirada do mercado das empresas inviáveis e realocação dos ativos destas nas atividades produtivas. Já na recuperação judicial, tutela a salvaguarda dos interesses focados na preservação da empresa que seja economicamente viável, sendo de fundamental importância para a superação de seu estado de crise econômico-financeira. Em ambas exerce a função de auxiliar da justiça em prol do interesse público, o qual, como destaca Haroldo Malheiros Duclerc Verçosa, encontra-se muito mais acentuado do que no diploma legal anterior ${ }^{118}$.

Ele exerce "munus"119 público, mas não é funcionário público ${ }^{120}$ e nem a ele é equiparado para fins penais ${ }^{121}$. $\mathrm{O}$ administrador judicial recebe o encargo de atuar na recuperação judicial ou na falência, em decorrência de disposição legal (daí se falar em "munus" público) e atua com verdadeiro auxiliar da justiça, com todas as funções, deveres e ônus decorrentes.

\footnotetext{
${ }_{117}$ Abrão, Nelson. O síndico na falência. $2^{\mathrm{a}}$ ed. São Paulo: Liv. e Ed. Universitária de Direito, 1.999, p. 34.

${ }^{118}$ VERÇOSA, Haroldo Malheiros Duclerc. In: SOUZA JUNIOR, Francisco Satiro de, e PITOMBO, Antônio Sérgio de A. Moraes. (coord.). Comentários à Lei de Recuperação de Empresas e Falência. Lei 11.101/2005. - Artigo por Artigo. $2^{\mathrm{a}}$ ed. São Paulo: Revista dos Tribunais, 2.007, p. 165.

${ }^{119}$ Waldemar Ferreira ressalta que "Múnus não é expressão de significado preciso na terminologia jurídica. Mesmo em Roma, de onde proveio, tanto por ela se designava o cargo, ofício ou emprego público, quanto os deveres de ordem social, como revelam os léxicos". FERRERA Waldemar. Tratado de Direito Comercial. Vol. $15^{\circ}$. São Paulo: Saraiva, 1.966, p. 314-315.

120 José Xavier Carvalho de Mendonça, ao tratar da figura jurídica dos síndicos e liquidatários da Lei 5.746/29 já assim dizia: "Eles são instituídos no interesse público, para a realização do exercício das funções que lhes são confiadas; não participam, porém, do exercício de poderes públicos, nem fazer parte de ramo da administração pública". MENDONÇA, José Xavier Carvalho de. Tratado de Direito Comercial. Vol. VIII. $2^{\mathrm{a}}$. ed. Rio de Janeiro: Freitas Bastos, 1.962, p. 31.

${ }^{121}$ No tocante à equiparação ou não do administrador judicial ao funcionário público, confira-se o tópico 3.6.2 infra.
} 
Vista essa questão pelo ângulo da doutrina administrativista, pode-se dizer que, ao atuar como auxiliar da justiça, sem ocupar posição que caracterize vínculo de trabalho com a Administração Pública - cargo ou emprego público - o administrador judicial corresponde à figura dita "particular em colaboração com o Poder Público"122 ou "particular em colaboração com a Administração"123.

A terminologia, como se nota, não é exata, eis que decorrente de construção doutrinária. Alguns autores preferem mesmo não recorrer a um nome específico, somente destacando que há agentes estatais em sentido amplo que não são "servidores" ou “empregados públicos" - expressões essas que, desde a Constituição de 1988, substituem, com sentido mais específico, o que anteriormente se dizia, em gênero, "funcionário público". É o caso de Marçal Justen Filho, que até mesmo trabalha com o exemplo dos peritos e síndicos de massa falida ${ }^{124}$

De todo modo, os particulares em colaboração com a Administração, ainda que incluídos por alguns no gênero mais amplo "agentes públicos", ou "agentes estatais", não passam a sofrer automaticamente a incidência de um regime jurídico aplicável aos servidores ou empregados públicos. Como decorre das lições de Odete Medauar, há que se buscar em leis específicas eventual equiparação àquelas figuras, para certos efeitos, conforme o caso ${ }^{125}$.

De resto, como será visto nos itens seguintes, o administrador judicial está sujeito a um regime jurídico que especificamente lhe traça a LRE, independentemente da classificação como "agente público" ou não.

\footnotetext{
${ }^{122}$ DI PIETRO, Maria Sylvia Zanella. Direito Administrativo. $27^{\mathrm{a}}$ ed. São Paulo: Atlas, 2014, p. 603.

${ }^{123}$ BANDEIRA DE MELLO, Celso Antônio. Curso de Direito Administrativo. $30^{\mathrm{a}}$ ed. São Paulo: Malheiros, 2013, p. 255.

${ }^{124}$ JUSTEN FILHO, Marçal. Curso de Direito Administrativo. $9^{a}$ ed. São Paulo: Revista dos Tribunais, 2013, pp. 898-899.

${ }_{125}$ MEDAUAR, Odete. Direito Administrativo Moderno. $18^{\mathrm{a}}$ ed. São Paulo: Revista dos Tribunais, 2014, p. 305.
} 


\title{
3.2 Nomeação.
}

Grande parte do sucesso ou insucesso de uma recuperação judicial ou principalmente de uma falência depende da atuação do administrador judicial, o que, por si só, demonstra a importância dos critérios adotados pelo legislador para a sua escolha.

Rubens Requião, ao discorrer sobre este órgão auxiliar da justiça, destaca que:

\begin{abstract}
Sua importância é ressaltada pelos juristas, tendo Percerou e Desserteaux observado que é o órgão essencial da falência, e ninguém, dentro do processo, tem um lugar comparável ao seu. Não há nada de exagerado, acentual esses autores, em dizer que é sobretudo de seu valor moral e profissional que depende, de fato, o sucesso da instituição (Des Faillites et Banqueroutes, vol II, n. 1083). 126
\end{abstract}

A forma de escolha e nomeação do administrador judicial sempre gerou inúmeras discussões doutrinárias, tanto em solo nacional como internacional. No curso da história, o poder da escolha tende a oscilar das mãos dos credores para as dos magistrados. Em vários países a escolha dos administradores judiciais é feita com base em listas oficiais; em outros, adota-se o critério de livre escolha do magistrado, ou de indicação ou anuência pelos credores, por exemplo.

Analisaremos o método utilizado pela LRE em confrontação com os critérios utilizados por outros sistemas jurídicos, aqui escolhidos por suas características na seleção e nomeação dos administradores. São sistemas que, como regra, selecionam os administradores judiciais previamente inscritos em listas oficiais, após atenderem a requisitos mais extensos do que os exigidos pela legislação pátria. São excepcionais as indicações de administradores judiciais que não estejam inscritos nessa lista, os quais, em qualquer caso, sujeitam-se aos critérios mínimos para a inscrição.

Vejamos, pois, os requisitos legais presentes na LRE e como é feita a escolha do administrador judicial em França, Portugal, Espanha e Estados Unidos. Neste ponto, mister se faz ressaltar que a apresentação dos sistemas jurídicos estrangeiros escolhidos é

${ }^{126}$ REQUIÃO, Rubens. Curso de direito falimentar. Falência. $1^{\text {o }}$ Vol. $6^{\mathrm{a}}$ ed. São Paulo: Saraiva, 1.981, p. 209. 
feita de forma panorâmica, não pretendendo esgotar o assunto aqui tratado. A análise tem por objetivo única e exclusivamente a verificação de alguns aspectos relevantes do administrador judicial nos seus respectivos países, a fim de possibilitar a reflexão sobre a viabilidade ou não de sua aplicação no Brasil, para um aperfeiçoamento deste órgão auxiliar da justiça, respeitando-se as peculiaridades jurídicas, culturais e sócio-econômicas de cada país. Os países foram escolhidos principalmente em face dos critérios adotados para a escolha do administrador judicial e sua manutenção no cargo. A escolha deveu-se também ao fato de os sistemas norte-americano e francês serem os precursores dos modelos de reorganização com ênfase na preservação das empresas, em contrapartida aos ordenamentos espanhol e português que adotaram um sistema de procedimento de insolvência unificado, com cunho nitidamente "pro-credor".

\subsubsection{Requisitos legais e critérios adotados para a nomeação.}

A alteração do enfoque dado às empresas em crise, com a entrada em vigor da LRE, fez com que as características necessárias do administrador judicial também fossem modificadas. Ao contrário do que previa a legislação revogada, o administrador judicial não é mais nomeado entre os maiores credores da falência, nem tampouco precisa ter domicílio na mesma comarca, ou não ter sido nomeado para a função em outro processo nos últimos seis meses, conforme prescrevia o artigo 60 da LF. Trata-se de um grande avanço em nossa legislação, deixando-se de lado os interesses particulares dos credores na satisfação de seus créditos para se buscar o rápido soerguimento da empresa viável, temporariamente em dificuldades, ou a solução das falidas da forma mais breve possível ${ }^{127}$.

A escolha correta do administrador judicial é de suma importância, pois repitase, uma má escolha pode ser a diferença entre um bom ou não resultado obtido principalmente na falência em face das funções por ele exercidas, mas também na

\footnotetext{
${ }^{127}$ Segundo Ecio Perin Júnior: “A tarefa do administrador judicial, numa empresa em crise, consiste em aplicar sua atividade no reerguimento do ente produtivo enfraquecido, não se submetendo a qualquer influência do devedor ou dos credores, agindo sob critérios próprios de convicções." PERIN JÚNIOR, Ecio. O administrador judicial e o comitê de credores. In: PAIVA, Luiz Fernando Valente de (coord.). Direito Falimentar e a nova lei de falências e recuperação de empresas. São Paulo: Quartier Latin, 2005, p. 174.
} 
recuperação judicial. Neste sentido, Paulo Fernando Campos Salles de Toledo, mesmo ao comentar a LF, já ressaltava que:

Do síndico, depende, por isso, em grande parte, o bom ou mau resultado da falência. Um síndico diligente irá trazer, para a massa, bens e recursos que um negligente sequer pensará que possam existir. Saberá fazer ilações, descobrir fatos que se supunham poder ficar ignorados, ganhar causas que a omissão poderia conduzir ao fracasso. ${ }^{128}$

Nos termos da atual legislação, a nomeação deve ser feita de acordo com os requisitos constantes no artigo 21 da LRE, que determina que o administrador judicial deve ser profissional idôneo, preferencialmente advogado, economista, administrador de empresas ou contador, ou pessoa jurídica especializada, observados, ainda, a inexistência dos impedimentos descritos no artigo 30 da LRE, melhor explicitados no tópico 3.3 infra.

Requisito legal, portanto, para assunção do cargo de administrador judicial, é a idoneidade, tanto do profissional pessoa física como da pessoa jurídica. Entendemos que tal característica deva aqui ser tratada em sentido amplo, ou seja, o administrador judicial deve ter idoneidade econômico-financeira e moral, como requeria expressamente a LF $^{129}$. Assim, além da boa reputação, o administrador judicial deve ter patrimônio ou recursos necessários para responder pelos deveres e obrigações decorrentes da sua função, ainda mais porque no Brasil não é obrigatório seguro ou caução para o exercício do cargo, como veremos no tópico 3.5 abaixo ao tratarmos da responsabilidade do administrador judicial.

O rol de profissões elencadas no "caput" do artigo 21 é meramente exemplificativo. Não se trata de imposição legal, mas de mera diretriz orientadora, cabendo exclusivamente ao juiz escolher o melhor profissional que atenda aos reclamos do caso concreto, seja qual for a sua profissão ${ }^{130}$. O que importa é que o administrador judicial detenha conhecimento técnico e prático suficientes para atender às finalidades da sua função.

\footnotetext{
${ }^{128}$ TOLEDO, Paulo Fernando Campos Salles de. A disciplina Jurídica das Empresas em Crise no Brasil: Sua Estrutura Institucional. In: Revista de Direito Mercantil, Industrial, Econômico e Financeiro n. 122, São Paulo: Malheiros, 2001, p. 171.

${ }^{129}$ Art. 60, "caput", "in fine", LF.

${ }^{130}$ VERÇOSA, Haroldo Malheiros Duclerc. In: SOUZA JUNIOR, Francisco Satiro de, e PITOMBO, Antônio Sérgio de A. Moraes. (coord.). Comentários à Lei de Recuperação de Empresas e Falência. Lei 11.101/2005. - Artigo por Artigo. $2^{a}$ ed. São Paulo: Revista dos Tribunais, 2007, p. 165.
} 
Neste sentido, Eduardo Goulart Pimenta aponta que o administrador judicial deve ter o embasamento teórico e prático necessários para fiscalizar o correto cumprimento do plano de recuperação, e, na falência "assumir a própria direção da atividade empresarial a fim de empreender sua liquidação"131.

Já Mauro Rodrigues Penteado alerta que:

O administrador judicial da falência e também o que atua como auxiliar na fiscalização da recuperação judicial são profissionais dos quais depende o bom andamento e mesmo o êxito dos procedimentos, daí o cuidado que deve ser adotado nas suas nomeações, evitando-se a consideração estrita do padrão preferencial referido na Lei, pois a atividade reclama não apenas a titularidade de graus acadêmicos, mas também independência e experiência, particularmente no ramo de negócios em que milita o devedor, pois sua atuação estará voltada para a fiscalização de empresa que enfrenta situação de crise econômico-financeira (art. 47), ou para a administração de empresa insolvente ou insolvável, com vistas à sua liquidação por padrões e mediante soluções empresariais (art. 140). ${ }^{132}$

Muito mais importante do que a profissão do administrador judicial será sua experiência na área de negócios de forma ampla, não só para as falências, como também para atuar nas recuperações judiciais posto que, não obstante não "administrar" a empresa em reorganização, apenas conseguirá fiscalizá-la a contento se tiver domínio do "dia-a-dia" do mercado empresarial. Por isso, o advogado, que geralmente era nomeado durante a vigência da LF, muito possivelmente não será o profissional mais indicado para tal cargo, exceto se além dos conhecimentos jurídicos, detenha também os necessários na área de gestão de empresas.

Além disso, em face da diversidade de áreas negociais existentes, com empresas de todas as áreas e portes, não é possível vislumbrar que o mesmo profissional possa atuar em todo e qualquer caso de recuperação judicial ou falência. Um administrador

${ }^{131}$ PIMENTA, Eduardo Goulart. Atribuições e Perfil do Administrador Judicial, Gestor Judicial e Comitê de Credores no Contexto da Lei n. 11.101/05. In: CASTRO, Moema A. S. De, e CARVALHO, William Eustáquio de (coord.). Direito Falimentar Contemporâneo. $1^{\text {a }}$ Ed. Porto Alegre: Sergio Antonio Fabris, 2008, p. $11 / 13$.

${ }^{132}$ PENTEADO, Mauro Rodrigues. In: CÔRREA-LIMA, Osmar Brina e LIMA, Sérgio Mourão Corrêa (coord.). Comentários à Nova lei de Falência e Recuperação de Empresas: Lei $n^{o} 11.101$, de 09 de fevereiro de 2005. $1^{\mathrm{a}}$ ed. Rio de Janeiro: Forense, 2009, p.162-163. 
judicial que atenda a pequenas e médias empresas poderá não dispor do suporte técnico e material necessário para a atuação em casos de grandes empresas ou grupos econômicos.

Ademais, como será visto no tópico 3.4 infra, as funções deste profissional divergem muito na recuperação judicial e na falência e, por isso mesmo, um ótimo administrador judicial com "expertise" na atuação de recuperações judiciais poderá não ter todas as qualidades necessárias para trabalhar de forma igualmente eficiente em uma falência.

Mauro Rodrigues Penteado vai mais longe e entende que, na recuperação judicial, a experiência e especialização requeridas dizem respeito ao domínio de conhecimentos sobretudo e diretamente no ramo de negócios do devedor e também nas várias modalidades de operações e procedimentos que podem ser adotados no plano de recuperação judicial (indo desde operações de reestruturação societárias e/ou financeiropatrimonais ou a alienação de estabelecimentos até negociações sindicais ou com trabalhadores). Já para a falência, ressalta que o administrador judicial deverá ter experiência e especialização "não só para atuar como verdadeiro e próprio administrador" para que possa preservar e também otimizar os ativos da empresa, como também "estar habilitado a operar as formas empresariais de alienação dos bens do ativo", da forma prevista na lei. Por tais razões, conclui que:

\footnotetext{
Por aí se vê que não há que se falar em uma única especialização, ou em padrão geral de especialização, tanto na recuperação judicial, quanto na falência, pois a qualificação a exigir do administrador judicial dependerá, caso a caso, do ramo de atividades do devedor, de sua situação econômica, financeira e patrimonial, do Plano que submete a juízo e aos credores (que, se simples moratória, poderá até ser fiscalizado por contador), da complexidade das reestruturações societárias ou econômico-financeiras, enfim, na liquidação, pelos meios e formas empresariais e expeditos previstos na Lei. ${ }^{133}$
}

Neste ponto, indagamos sobre a possibilidade e/ou necessidade de nomeação de mais de um administrador judicial no mesmo processo. Com efeito, a LRE não admite expressamente, mas também não proíbe a nomeação múltipla. A legislação pátria, em todos

133 PENTEADO, Mauro Rodrigues. In: CÔRREA-LIMA, Osmar Brina e LIMA, Sérgio Mourão Corrêa (coord.). Comentários à Nova lei de Falência e Recuperação de Empresas: Lei $n^{\circ} 11.101$, de 09 de fevereiro de 2005. $1^{\mathrm{a}}$ ed. Rio de Janeiro: Forense, 2.009, p.164-165. 
os artigos em que se refere ao administrador judicial, o faz no singular, seja ele pessoa física ou jurídica. O que a LRE faculta de forma expressa é a contratação de profissionais ou empresas especializados, mediante autorização judicial, para auxiliar o administrador judicial no exercício de suas funções, consoante se infere da leitura de seus artigos $7^{\circ}$ e 22 , inciso I, alínea "h", inciso III, alínea "h" e parágrafo $1^{\text {․ }}$

Caso um administrador judicial seja insuficiente para exercer todas as suas funções em uma recuperação judicial ou em uma falência, muito provavelmente não será o profissional mais competente e eficaz para a atuação no caso concreto. Dentro do espírito do artigo 21 da LRE, mais correta será a nomeação de outro profissional, pessoa física ou pessoa jurídica, que tenha a estrutura e a "expertise" mais adequadas e suficientes para a recuperação judicial ou falência em questão.

A possibilidade de nomeação múltipla deve ocorrer em caráter excepcional, única e exclusivamente para as hipóteses de recuperações judiciais ou falências de grande complexidade ou volume, nas quais não seja possível que um administrador judicial (mesmo que amparado por uma equipe) consiga conduzir suas funções e obter resultados da forma desejada ${ }^{134}{ }^{135}$, como já ocorre em outros países, como França, Espanha e Portugal, por exemplo. Note-se que para essas hipóteses de nomeação múltipla, é de extrema importância que o magistrado descrimine a esfera de atuação de cada profissional, inclusive para efeitos de responsabilidade. Para todos os demais casos, vale repetir, o administrador judicial, seja pessoa física ou jurídica, deve contar com uma equipe que

\footnotetext{
${ }^{134}$ Neste sentido, Alfredo Luiz Kulgemas e Gustavo Henrique Sader de Arruda Pinto: "Possível é, também, impedimento não havendo na lei, a nomeação pelo juiz de 2 (dois) administradores judiciais para atuarem em conjunto na condução do processo de falência, repartindo entre si os honorários, sem nenhum ônus adicional para a massa, em casos tais em que, devido ao seu porte e complexidade, a divisão de tarefas entre os administradores possa vir a contribuir para a maior celeridade no andamento do processo e na tomada das providências necessárias no interesse da massa, sendo que, na eventual falta de um, não sofreria o processo solução de continuidade, pois inteirado já estaria o outro do caso." KUGELMAS, Alfredo Luiz, e ARRUDA PINTO, Gustavo Henrique Sader de. Administrador judicial na recuperação judicial: Aspectos Práticos. In: DELUCCA, Newton de, e DOMINGUES, Alessandra de Azevedo (coord.). Direito Recuperacional. Aspectos teóricos e práticos. $1^{\mathrm{a}}$ ed. São Paulo: Quartier Latin, 2.009, p. 228.

${ }^{135}$ A jurisprudência não é uníssona neste sentido. Verificamos posicionamentos favoráveis cf. TJSP, AI n. 990.10.141195-4, Rel. Des. Sebastião Carlos Garcia, 6a Câmara de Direito Privado, v.u., j. 07/10/10; e contrários cf. TJSP, AI n. 449.290-4/1-00, Rel. Des. José Roberto Lino Machado, Câmara de Falências e Recuperações Judiciais de Direito Privado, v.u., j. 20/09/06.
} 
consiga atuar da forma completa e consistente e que onere a empresa em recuperação judicial ou a massa falida o menos possível para atender às finalidades da $\operatorname{LRE}^{136}$.

Alberto Camiña Moreira destaca a importância da profissionalização da atividade do administrador judicial, que deve ser dotado de equipe de profissionais:

\begin{abstract}
A atividade do administrador é uma atividade que precisa ser profissionalizada. Não pode ser pessoa da confiança do juiz que ele escolha segundo seu agrado. As funções do administrador deveriam ser assumidas por um corpo de profissionais. Ainda que seja pessoa de sua confiança, deveria ser pessoa constante de um elenco, de alguma maneira, profissional para essa administração da falência. ${ }^{137}$
\end{abstract}

Destarte, a escolha do administrador judicial pelo magistrado deverá ser feita tomando-se em conta o caso concreto: o administrador judicial adequado não será somente o profissional idôneo e de confiança do juiz, mas aquele que, além disso, igualmente detenha conhecimentos práticos e técnicos na área de empresas, para que possa acompanhar a recuperação judicial ou falência da forma mais completa possível.

O administrador judicial poderá ser pessoa física ou pessoa jurídica especializada, devendo, nesta última hipótese, declarar o nome do profissional responsável pela condução do processo de recuperação judicial ou de falência, o qual não poderá ser substituído sem autorização do juiz ${ }^{138}$. Desta forma, resta preservado o princípio da identidade física da pessoa responsável pela condução das funções legalmente previstas, assumindo pessoalmente todas as responsabilidades inerentes ao encargo.

Ao determinar que a pessoa jurídica deve ser "especializada", a intenção da lei foi restringir o acesso a este órgão a pessoas jurídicas voltadas justamente para o ramo de recuperação judicial ou falência, ainda que não seja condição "sine qua non" para a sua atuação ter como seu objeto social "a prestação de serviços de administração judicial de

\footnotetext{
${ }^{136}$ Nelson Abrão, ainda quando em vigor a LF, já alertava para a delegação abusiva das funções dos síndicos aos seus prepostos que como "longa manus" exerciam grande parte das atividades privativas do profissional e ressaltava a importância de o síndico dispor de equipe técnica, eficaz e competente para evitar prejuízos à massa e, consequentemente, aos credores. ABRÃO, Nelson. $O$ síndico na falência. $2^{\mathrm{a}}$ ed. São Paulo: Liv. e Ed. Universitária de Direito, 1.999, p. 107.

${ }^{137}$ MOREIRA, Alberto Camiña. In: CASTRO, Rodrigo R. Monteiro de e ARAGÃO, Leandro Santos de (coord.). Direito Societário e a Nova Lei de Falências e Recuperação de Empresas. São Paulo: Quartier Latin, 2.006, p. 408.

${ }^{138}$ Art. 21, § único, LRE.
} 
recuperação judicial e/ou falência" de forma expressa ${ }^{139}$. Desta forma, poderão atuar como administradores judiciais sociedades dotadas de profissionais de formação diversa, como administradores de empresas, contadores, economistas, advogados ${ }^{140}$, dentre outros.

A atividade do administrador judicial, sob a ótica dada pela LRE, é tipicamente empresarial, nos termos do artigo 966 do CC, já ele que exerce, de forma profissional, atividade econômica, organizada, para a produção de serviços. Com efeito, verificamos que o administrador judicial se enquadra em todos os requisitos constantes do clássico "Perfil Subjetivo da Empresa - Empresa como Empresário" de Alberto Asquini, a saber: i) "quem exerce": necessidade de existência de uma pessoa (física ou júridica); ii) "atividade": prática de atos seriados coordenados entre si com continuidade indeterminada, com finalidade lícita; iii) "econômica": atividade criadora de riqueza (bens ou serviços); iv) "organizada": organização do trabalho alheio e do capital próprio e alheio, adicionada à assunção do risco do empresário, independentemente da existência de um estabelecimento; v) "profissionalmente": caráter de continuidade e constância; vi) "para a produção ou a circulação de bens ou de serviços": escopo da atividade, que deve ser dirigida ao mercado $^{141}$. Assim, o administrador judicial só não será considerado empresário em hipóteses excepcionais, como por exemplo, no caso dos advogados por vedação expressa dos artigos 16 e seguintes da Lei 8.906/94 (Estatuto da Advocacia e da Ordem dos Advogados do Brasil).

Além dos requisitos estabelecidos na LRE, outras exigências formais poderão ser acrescidas pelos tribunais de justiça de cada Estado, como ocorre, por exemplo, em São Paulo. Segundo o Provimento 797/2003 do Conselho Superior de Magistratura do Tribunal

\footnotetext{
${ }^{139}$ Neste sentido Sérgio Campinho alerta que “(...), a alusão contida no texto legal a que seja 'especializada' funciona como elemento de restrição à sua eleição. Assim, não pode uma sociedade, cujo objeto consista na prestação de serviços médicos, por exemplo, ser indicada para a função. São consideradas 'especializadas', dentre outras, aquelas pessoas jurídicas cujos respectivos objetos se voltem para a realização de auditorias, administração de patrimônio de terceiros e consultorias econômica financeira." CAMPINHO, Sérgio. Falência e Recuperação de Empresa: O novo regime da insolvência empresarial. $6^{\mathrm{a}}$ ed. Rio de Janeiro: Renovar, 2.012, p. 59.

${ }^{140}$ Os advogados sócios das sociedades multidisciplinares não poderão, no entanto, prestar serviços jurídicos em nome dessas pessoas jurídicas, em face do disposto no art. 16, caput, da Lei 8.906/94 (Estatuto da Advocacia e da Ordem dos Advogados do Brasil). Os serviços jurídicos, neste caso, deverão ser prestados por terceiros contratados, que podem ser, inclusive, esses mesmos advogados, por sua pessoa física ou através de uma sociedade de advogados da qual faça parte.

${ }^{141}$ ASQUINI, Alberto. Profili dell'impresa, in Rivista del Diritto Commerciale, 1943, v. 41, I. Trad. Fábio Konder Comparato. Perfis da empresa. Revista de Direito Mercantil, Industrial, Econômico e Financeiro. São Paulo. Malheiros. Ano XXXV, n. 104, Outubro-Dezembro/1.996, p. 109-126.
} 
de Justiça do Estado de São Paulo ${ }^{142}$, o administrador judicial deve, quando nomeado pela primeira vez, apresentar no respectivo cartório, no prazo de dez dias: i) “curriculum vitae”, com informações sobre sua formação profissional, qualificação técnica ou científica, experiência e áreas de atuação para as quais esteja apto, bem como o email por meio do qual será intimado; ii) declaração de que não possui vinculo de parentesco sanguíneo, por afinidade ou civil por linha ascendente, descendente ou colateral, até quarto grau, com juízes e servidores da unidade judiciária na qual atuará; iii) cópia de certidões de distribuidores cíveis e criminais das comarcas da capital e de seu domicilio dos últimos dez anos; iv) declaração de que não se opõe à vista de seu prontuário pelas partes e demais interessados; v) "outros documentos”, a critério do juiz.

Desde que obedecidos os requisitos constantes no artigo 21 da LRE, ou seja, desde que seja profissional, pessoa física ou pessoa jurídica, idôneos e especializados e, eventualmente, algum outro pressuposto formal exigido por cada Estado, a escolha do administrador judicial fica a critério exclusivo do magistrado, sem a prévia oitiva de credores, do devedor e/ou de terceiros, visto tratar-se de cargo de confiança ${ }^{143}$.

Note-se que a redação original da LRE previa no artigo 35, inciso I, alínea "c" e inciso II, alínea "a", a possibilidade de substituição do administrador judicial e indicação do substituto pela assembleia-geral de credores. $\mathrm{O}$ veto presidencial a tais dispositivos deuse sob os argumentos de que: i) estar-se-ía conferindo atribuições de competências idênticas a órgãos distintos (juiz e assembleia de credores) em evidente confronto entre estes dispositivos e o artigo 52, inciso I (que estabelece a nomeação do administrador judicial pelo juiz no ato do deferimento do processamento da recuperação judicial) e o artigo 23, parágrafo único (que dispõe sobre a destituição do administrador judicial pelo

\footnotetext{
142 TRIBUNAL DE JUSTIÇA DO ESTADO DE SÃO PAULO. Conselho Superior de magistratura. Disponível em: http://esaj.tjsp.jus.br/gcnPtl/abrirDetalhesLegislacao.do?cdLegislacaoEdit=34732\&flBtVoltar=N. Acesso em 01/10/2.013.

${ }^{143}$ Segundo David Giansante, na Comarca da Capital de São Paulo, alguns juízes adotam o critério da "confiança pura, nomeando apenas aqueles profissionais, que no seu ponto de vista, possuem capacidade profissional e idoneidade para o encargo", enquanto outros nomeiam novos profissionais em "casos pequenos, para depois, em sendo demonstrada a competência e merecimento, nomeá-lo em grandes casos" enquanto que os profissionais "renomados serão nomeados simultaneamente, em pequenos e grandes casos, auxiliando o Poder Judiciário nos pequenos, com baixa ou nenhuma remuneração e sendo 'premiados' ou 'compensados' com as falências de grande repercussão”. GIANSANTE, David C. O administrador judicial no processo falimentar. In: LAZZARINI, Alexandre A., KODAMA, Thais e CALHEIROS, Paulo (coord.). Recuperação de Empresas e Falência. Aspectos práticos e relevantes da Lei 11.101/05. $1^{\text {a }}$ ed. São Paulo: Quartier Latin, 2.014, p. 284.
} 
juiz); ii) teria havido um equívoco do legislador ao mencionar o "administrador judicial" no lugar de "gestor judicial" previsto no artigo 65 da LRE; e iii) com o veto se afastaria a possibilidade de que seja nomeada para o encargo pessoa que não seja da confiança do juízo ${ }^{144}$.

Atualmente verificamos nova tentativa de alteração legal, com o anteprojeto do Novo Código Comercial $^{145}$ que prevê a possibilidade de o devedor em recuperação judicial indicar o administrador judicial de sua preferência (artigo 51, inciso X), devendo ser ratificado ou substituído em assembleia-geral de credores (artigo 35, inciso I, alínea "g”). Referido anteprojeto também prevê a necessidade de ratificação ou substituição do administrador judicial pela assembleia-geral de credores, nomeado pelo magistrado na sentença de decretação da falência (artigo 99, inciso IX c/c artigo 35, inciso I, alínea “e”).

Justamente pelo fato de o administrador judicial dever gozar de ampla e total confiança do juízo, a escolha de forma discricionária do magistrado não poderá questionada exceto nas hipóteses de falta de idoneidade ou profissionalismo do escolhido ou, ainda, na ocorrência de alguma das hipóteses de impedimento previstas no artigo 30 da LRE, conforme será discutido de forma mais detalhada no tópico 3.3 infra. Mesmo assim, o administrador judicial está sujeito à fiscalização do comitê de credores, quando houver, nos termos do art. 27, inciso I, alínea "a" da LRE.

Não obstante tratar-se de encargo de confiança, questiona-se se a escolha deve ficar a critério discricionário do juiz, sendo suficiente apenas a aplicação dos requisitos constantes da LRE ou se outros devem ser adotados. Embora saibamos que a comparação de sistemas legislativos deva ser feita com cautela, posto que cada país adota a legislação falimentar melhor adaptada ao seu "contexto econômico, empresarial, jurídico e cultura local" ${ }^{146}$, acreditamos que o estudo do direito comparado, seja produtivo para a discussão em questão.

\footnotetext{
${ }^{144}$ Mensagem n. 59, de 9 de janeiro de 2.005, da Subchefia para Assuntos Jurídicos da Casa Civil da Presidência da República, com veto parcial ao Projeto de Lei n. 4.376/93 (PL n. 71/2003 no Senado Federal). ${ }_{145}$ Projeto de Lei do Senado Federal n. 487/2013.

146 PENTEADO, Mauro Rodrigues. In: CÔRREA-LIMA, Osmar Brina e LIMA, Sérgio Mourão Corrêa (coord.). Comentários à Nova lei de Falência e Recuperação de Empresas: Lei $n^{o} 11.101$, de 09 de fevereiro de 2005. $1^{\mathrm{a}}$ ed. Rio de Janeiro: Forense, 2.009, p.127; e LISBOA, Marcos de Barros, DAMASO, Otávio Ribeiro, SANTOS, Bruno Carazza dos, COSTA, Ana Carla Abrão. A Racionalidade Econômica da Nova Lei
} 
$\mathrm{Na}$ França, encontramos um dos mais rígidos e estruturados sistemas de ingresso e também de manutenção nos quadros de administradores judiciais, lá chamados de "administrateurs judiciaires"147, disciplinado pelo "Code de Commerce" (Código de Comércio).

O administrador judicial executa várias tarefas, dentre as quais destacamos: i) o acompanhamento dos negócios e do funcionamento da empresa, podendo assistir ou substituir a gestão; ii) a preparação de relatórios sobre a situação econômica e social do devedor, que servirão de base para o tribunal pronunciar-se sobre o plano de salvaguarda ou se a empresa deve ser reorganizada, vendida ou liquidada e como isto deve acontecer; iii) a elaboração de um projeto de plano nos procedimentos concursais, denominados "sauvegard" e "redressement judiciaire"148. Ele também pode ser nomeado em processo de liquidação judicial, a fim de gerenciar o devedor, no caso de manutenção provisória de suas atividades para posterior liquidação, por exemplo ${ }^{149}$.

A presença dos administradores judiciais apenas não é obrigatória para as companhias que possuem menos de 20 (vinte) empregados e volume de negócios abaixo de 3 (três) milhões de euros ${ }^{150}$.

Além das diferenças nas atividades exercidas pelo administrador judicial francês em comparação com o brasileiro, outro grande fator distintivo é que, na França, ele é profissional liberal ${ }^{151}$, sendo sua profissão reconhecida legalmente.

O acesso à profissão é feito por nomeação do tribunal, não havendo, no entanto, livre discricionariedade do juiz para tal escolha. Ninguém poderá ser nomeado administrador ou mandatário judicial se não estiver inscrito na lista estabelecida pelo Conselho Nacional de Administradores e de Mandatários Judiciais ("Conseil National des

de Falências e de Recuperação de Empresas. In: PAIVA, Luiz Fernando Valente de (coord.). Direito Falimentar e a nova lei de falências e recuperação de empresas. São Paulo: Quartier Latin, 2.005, p. 37.

${ }^{147}$ Cumpre esclarecer que na França, além dos "administrateurs judiciaires", atuam também os "mandataires judiciaires". O mandatário judicial é nomeado para, no processo de recuperação, proceder à verificação dos créditos e só agir em nome e no interesse dos credores; e, na falência, além de representar os credores, exercer a função de liquidante, realizando dos ativos para pagamento de credores. Na verdade, como ressalta Márcio Souza de Guimarães, representar os credores não significa ser seu advogado, mas sim ser responsável pelo manejo eficaz dos créditos. GUIMARÃES, Márcio Souza. Le role du ministère public dans lês procédures collectives (approche de droit compare français et brésilien). Villeneuve d'Ascq: Atelier National de Reproduction des Thèses: 2011, p. 413-421.

${ }_{148}$ Art. L626-2 e ss e art. L631-19 e ss., respectivamente, Code de Commerce.

${ }^{149}$ Art. L641-10, Code de Commerce.

${ }^{150}$ Art. R626-52 c/c R621-11, Code de Commerce.

151 Disponível em http://www.metiers.justice.gouv.fr/la-justice-hors-de-la-fonction-publique$\underline{12684 / \text { administrateur-judiciaire-et-mandataire-judiciaire-26864.html. Acesso 20/02/2014. }}$. 
Administrateurs Judiciaires et Mandataires Judiciaires - CNAJM"), salvo em situações excepcionais, nas quais será nomeada uma pessoa com comprovada experiência e qualificação especial com relação a determinadas matérias, mas que deverá atender aos demais requisitos legais e cumprir as mesmas obrigações impostas aos administradores judiciais e não terá o direito de exercer tal profissão de maneira habitual ${ }^{152}$.

Além da necessidade de estar o profissional inscrito na supracitada lista, o Código Comercial francês também estabelece requisitos de nacionalidade, competência, moralidade e qualificação técnica. São eles: (i) ser francês ou cidadão de um EstadoMembro da Comunidade Europeia ou de Estado-parte do Acordo sobre o Espaço Econômico Europeu (EEE); (ii) não ter cometido atos contrários à honra ou que levaram a uma condenação criminal; (iii) não ter cometido atos que resultaram em sanção disciplinar ou administrativa de demissão, cancelamento, revogação, rescisão de acordo ou retirada de autorização; (iv) não ter sofrido falência pessoal ou uma das medidas de interdição ou de perda de poder previstas na legislação; (v) ter sido aprovado no exame de acesso ao estágio profissional, cumprir esse estágio por três anos e ser aprovado com sucesso no exame de aptidão às funções de administrador judicial, devendo, para tanto, ser detentor de certificados ou diplomas previstos por decreto. Somente estão dispensadas dos exames e/ou do estágio as pessoas que preencham as condições de competência e de experiência profissional fixadas por decisão do Conselho de Estado ou que tenham adquirido em outro Estado membro da Comunidade Europeia ou de um Estado-parte do Acordo sobre o Espaço Econômico Europeu uma condição suficiente para o exercício da profissão de administrador judicial. As pessoas jurídicas não podem exercer a função de administrador judicial senão por intermédio de um dos seus membros inscritos na lista ${ }^{153}$.

Normalmente a escolha pelo tribunal de uma pessoa física ou de uma pessoa jurídica (com a indicação expressa de uma ou mais pessoas físicas que irão atuar no caso) é feita com base na localização, experiência ou qualificação peculiar relacionada à natureza do caso. Os administradores têm uma jurisdição nacional ${ }^{154}$, mas, na prática, atuam em distritos específicos de acordo com o estabelecido pelo tribunal mais próximo ${ }^{155}$.

\footnotetext{
${ }^{152}$ Art. L811-2, Code de Commerce.

${ }^{153}$ Art. L811-5, Code de Commerce.

${ }^{154}$ Art. L811-9, Code de Commerce.

155 DUPOUX, Cécile e NERGUARARIAN, Carole. National Report for France. In: FABER, Dennis, VERMUT, Niels, KILBORN, Jason e RICHTER, Tomás. Commencement of Insolvency Proceedings. Oxford: Oxford University Press, 2.012, p. 298.
} 
$\mathrm{O}$ direito francês detém, assim, um sistema rígido de acesso à profissão de administrador judicial. A doutrina ressalta que o exame de acesso ao estágio profissional é competitivo, além de ser necessário o cumprimento de três anos de estágio com um administrador judicial, além da aprovação final do exame de aptidão. Segundo Cécile Dupoux e Carole Nerguararian, o difícil processo seletivo permite somente que poucas pessoas possam exercer a profissão ${ }^{156}$.

Além disso, os administradores judiciais franceses são constantemente monitorados, posto estarem sob a supervisão direita do Ministério Público ${ }^{157}$. Eles igualmente estão sujeitos às inspeções realizadas pela autoridade pública e são obrigados a fornecer todas as informações ou documentos relevantes sem poder invocar o sigilo profissional $^{158}$. Não obstante essa fiscalização, os administradores judiciais também são obrigados a indicar um auditor de contas encarregado de supervisionar a contabilidade e exercer um controle do conjunto de ativos pertencentes a terceiros e que estejam com o administrador judicial em decorrência de mandato conferido no exercício de suas funções ${ }^{159}$.

Os administradores judiciais franceses, regularmente inscritos nas listas de profissionais habilitados ao exercício da respectiva função, devem observar também às regras de conduta (charte qualité des administrateurs et des mandataires judiciaires ${ }^{160}$ ) reguladas pelo Conselho Nacional de Administradores e de Mandatários Judiciais, órgão de representação nacional por meio do qual se compatibiliza a atuação dos administradores e mandatários judiciais a regras profissionais, éticas e deontológicas para o exercício da profissão, das quais se ressalta principalmente o compromisso com a divulgação de informação e transparência e os padrões de eficiência e de desempenho econômico. $\mathrm{O}$ Código de Comércio francês é expresso no sentido de que referido Conselho Nacional deve velar pela defesa dos interesses coletivos dos administradores e mandatários judiciais, mas também é responsável pelo cumprimento das obrigações profissionais de seus membros, inclusive de atualização de seus conhecimentos ${ }^{161}$.

\footnotetext{
156 DUPOUX, Cécile e NERGUARARIAN, Carole. National National Report for France. In: FABER, Dennis, VERMUT, Niels, KILBORN, Jason e RICHTER, Tomás. Commencement of Insolvency Proceedings. Oxford: Oxford University Press, 2.012, p. 298.

${ }^{157}$ Art. L811-11, Code de Commerce.

${ }^{158}$ Art. L811-11, Code de Commerce.

${ }^{159}$ Art. L811-11-1, Code de Commerce.

${ }^{160}$ Disponível em: http://www.cnajmj.fr/presentation/charte-qualite; acesso em 25/04/2.014.

${ }^{161}$ Art. L814-2, "Code de Commerce".
} 
Ainda que não detenha um sistema tão eficiente e organizado como a França, Portugal possui também interessantes critérios para a nomeação do administrador judicial, no Código de Insolvência e da Recuperação de Empresas (Decreto-lei 53/04) e, principalmente para o acesso a tal atividade, no recém atualizado Estatuto do Administrador Judicial (Lei 22/2013).

Em Portugal, face à adoção de sistema de insolvência comprometido primordialmente com a satisfação dos credores, o administrador judicial possui várias competências, além de um poder de discricionariedade e "verdadeira força de orientação quanto ao destino da empresa" ${ }^{162}$, cabendo a ele proceder a um inventário dos bens e direitos da "massa insolvente", a relação de credores, e um relatório contendo a análise dos registros contábeis do devedor e indicando as perspectivas de manutenção da empresa e da conveniência ou não de aprovação do plano de insolvência ${ }^{163}$. Também compete a ele a verificação dos créditos e a administração da "massa insolvente", via de regra, desde a declaração de insolvência ${ }^{164}{ }^{165}$.

Ao disciplinar sobre os "órgãos da insolvência", o Código de Insolvência e da Recuperação de Empresas (CIRE) dispõe ser de competência do juiz a escolha e nomeação do "administrador judicial provisório", dentre os membros inscritos na "lista oficial de administradores de insolvência" ${ }^{166}$. Este administrador judicial exercerá suas funções até que seja proferida a sentença, ocasião em que será nomeado o "administrador de insolvência" "167, dando-se preferência para o já nomeado administrador judicial provisório $^{168}$.

A lei portuguesa permite que, após a designação do "administrador da insolvência”, os credores escolham, em assembleia de credores, outra pessoa para o cargo, bem como determinem sua remuneração ${ }^{169}$. A possibilidade de escolha de nomes não

\footnotetext{
162 PUGLIESI, Adriana Valéria. Direito Falimentar e Preservação da Empresa. São Paulo: Quartier Latin, 2.013, p. 101-109.

${ }^{163}$ Art. 153 a 155 , CIRE.

${ }^{164}$ Art. 81, CIRE.

${ }^{165}$ A administração da "massa insolvente" pelo devedor somente ocorre em caráter excepcional, cf. art. 36, al. "e" e art. 223 e ss., CIRE.

${ }^{166}$ Art. 32, 1, CIRE.

${ }^{167}$ Art. 32, 2, c/c art. 52, 2, CIRE.

${ }^{168}$ Art. 52, 2, CIRE.

${ }^{169}$ Art. 53, 1, CIRE.
} 
inscritos nas listas oficiais é excepcional e somente admitida para as hipóteses justificadas pela "especial dimensão da empresa", pela "especificidade do ramo de atividade" ou em face da "complexidade do processo"170. O juiz somente não aceitará o nome escolhido pelos credores se entender pela falta de aptidão ou idoneidade, que a remuneração é excessiva, ou, no caso de pessoa não inscrita na lista oficial, se não verificar nenhuma das três exceções acima descritas ${ }^{171}$.

O devedor poderá indicar o nome do administrador judicial apenas nos casos de processos em que seja "previsível a existência de atos de gestão que requeiram procedimentos especiais" ${ }^{\text {"172 }}$, cabendo ao juiz aceitar ou não.

A atividade dos administradores judiciais está regulada de forma minuciosa pelo Estatuto do Administrador Judicial Português. A Lei 22, em vigor desde 26 de março de 2013, regulamenta o acesso à atividade, os direitos e devedores desses profissionais, sua remuneração, além de detalhar seu regime sancionatório, dotado, inclusive de processo disciplinar.

No que diz respeito à nomeação, referido Estatuto não deixa dúvidas de que apenas poderão ser nomeados "administradores judiciais" (englobando neste termo, os administradores provisórios, os administradores de insolvência ou fiduciários ${ }^{173}$ ) aqueles que constem das listas oficiais, salvo as hipóteses acima já descritas.

Sem prejuízo de a nomeação ser feita pelo juiz da forma acima descrita, o Estatuto prevê que a escolha deverá ser feita por meio de "sistema informático" para assegurar a "aleatoriedade da escolha e a distribuição em idêntico número dos administradores nos processos" ${ }^{174}$, o que, quando em vigor, acabará por reduzir substancialmente o critério discricionário do magistrado.

Apenas podem ser administradores judiciais em Portugal, as pessoas que, cumulativamente: i) tenham "licenciatura e experiência profissional adequada ao exercício

\footnotetext{
170 Art. 53, 2, CIRE.

${ }^{171}$ Art. 53, 3, CIRE.

${ }^{172}$ Art. 32, 1, CIRE.

${ }^{173}$ Art. $2^{\circ}, 2$, Lei $22 / 13$.

${ }^{174}$ Art. 13, 2, Lei 22/13.
} 
da atividade", consideradas pelo Estatuto como "aquelas que, apreciadas conjuntamente, atestem a existência de formação de base e experiência do candidato na generalidade das matérias sobre que verba o exame de admissão; ii) tenham feito o estágio profissional; iii) tenham sido aprovados no exame de admissão; iv) não se encontrem em nenhuma situação de incompatibilidade e sejam pessoas idôneas para o exercício da atividade ${ }^{175}$.

Para a inscrição no estágio, o candidato deve apresentar uma série de documentos, em especial: i) "curriculum vitae"; ii) certificado de licenciatura, iii) certidão de antecedentes criminais; iv) declarações de idoneidade, sobre o exercício de qualquer outra atividade remunerada e sobre a inexistência de incompatibilidades; v) declaração sobre sua situação financeira, com discriminação de proventos auferidos e encargos suportados; vi) atestado médico, caso o candidato tiver 70 (setenta) anos completos; vii) esclarecimentos sobre quais listas de administradores judiciais pretende integrar $\left(\operatorname{artigo} 7^{\circ}\right.$ ). O estágio profissional tem duração de seis meses, contando com parte teórica (2 meses) e prática $(4 \text { meses })^{176}$.

O exame de admissão engloba relação extensa de matérias não exclusivamente jurídicas: i) direito comercial e o Código de Insolvência e da Recuperação de Empresas; ii) direito processual civil; iii) direito do trabalho; iv) contabilidade; v) economia e gestão de empresas; vi) regras de ética e deontológicas; vii) prática da atividade de administrador judicial.

Já a Espanha, da mesma forma que o Brasil, não possui um código de conduta específico para o administrador judicial, contando somente com a "Ley Concursal" (Lei $22 / 2003)^{177}$. O sistema de nomeação dos administradores judiciais também sofreu grandes alterações com a entrada em vigor da Lei 22/2003, a qual, aliás, foi sendo alterada ao longo desta última década. Em sua redação original, o administrador judicial era um órgão colegiado integrado com um advogado, um economista, "titulado mercantil" ou auditor de contas, e um credor "ordinário" ou "com privilégio geral sem garantia".

\footnotetext{
${ }^{175}$ Art. $3^{\circ}$, Lei $22 / 13$.

${ }^{176}$ Art. $9^{\circ}$, Lei $22 / 13$.

${ }^{177}$ TIRADO, Ignácio. National Report for Spain. In: FABER, Dennis, VERMUT, Niels, KILBORN, Jason e RICHTER, Tomás. Commencement of Insolvency Proceedings. Oxford: Oxford University Press, 2.012, p. 641.
} 
Com a finalidade de reduzir os gastos processuais, a Lei 38/2011 reduziu para uma única pessoa tal cargo, passando a administração concursal a ser exercida por: i) um advogado em exercício com experiência profissional de 5 (cinco) anos e formação especializada em direito concursal; ou ii) um economista, "titulado mercantil" ou auditor de contas com o mesmo tempo de experiência profissional e com especialização na área concursal. Poderá também ser pessoa jurídica desde que composta de pelo menos um advogado e um economista, "titulado mercantil" ou auditor de contas ${ }^{178}$.

Apenas fará parte da administração concursal um credor "ordinário" ou "com privilégio geral sem garantia" nas hipóteses de "concursos ordinarios de especial trascedencia" assim designados aqueles que detenham um dos seguintes pressupostos: i) o número de trabalhadores seja ou tenha sido em algum dos 3 (três) exercícios anteriores ao do concurso superior a 100 (cem); ii) o número de credores declarados pelo devedor seja superior a 1000 (hum mil); iii) o valor da dívida declarada pelo devedor seja superior a cem milhões de euros; iv) a receita anual do devedor tenha sido cem milhões de euros ou valor superior em qualquer um dos 3 (três) exercícios anteriores ao do exercício do concurso $^{179}$. A nomeação também é feita de forma distinta nos casos de concursos de uma entidade emissora de valores mobiliários, em cujo caso o administrador judicial será um membro do pessoal técnico da Comissão Nacional do Mercado de Valores ou pessoa com qualificação idêntica, indicada por esta; e nos casos de entidades de crédito ou seguradoras, nos quais o juiz nomeará o administrador judicial entre os indicados pelo Fundo de Garantia de Depósitos e o Consorcio de Compensação de Seguros, respectivamente ${ }^{180}$.

Os profissionais que desejarem atuar como administradores judiciais e que preencham os requisitos descritos acima devem se inscrever no Registro Oficial de Auditores de Contas ou nos órgãos profissionais respectivos, os quais apresentam, sempre no mês de dezembro, aos tribunais (“decanato de juzgados") as listas de administradores judiciais que entrarão em vigor para o ano seguinte ${ }^{181}$.

\footnotetext{
${ }^{178}$ Art. 27, 1, Lei 22/2003.

${ }^{179}$ Art. $27,2,3^{\circ} \mathrm{c} / \mathrm{c}$ art. 27, bis, Lei 22/2003.

${ }^{180}$ Art. $27,2,1^{\circ}$ e $2^{\circ}$, Lei $22 / 2003$.

${ }^{181}$ Art. 27, 3, Lei 22/2003.
} 
O juiz nomeará os administradores judiciais, "buscando uma distribuição equitativa das designações entre os incluídos nas listas acima referidas", com exceção de casos específicos nos quais seja exigida experiência ou formação especial ${ }^{182}$.

Segundo Ignácio Tirado, a introdução do sistema de nomeação dos administradores judiciais baseadas em listas oficiais teve por objetivo acabar com as “corruptelas" derivadas da concentração das nomeações judiciais de poucos profissionais. Por outro lado, tal sistema não retirou a discricionariedade do magistrado no exercício de suas competências, haja vista que ficará a seu critério a escolha após a ponderação de todas as características subjetivas dos integrantes das listas e sua adequação ao caso concreto. $\mathrm{O}$ juiz nomeará, assim, os sujeitos com melhor nível de formação e prática mais adequados às características do devedor, tendo como única limitação imposta pela lei o número máximo de 3 (três) nomeações do profissional por juiz em um período de 2 (dois) anos ${ }^{183}$, sendo certo que esta limitação não vigora para as pessoas jurídicas. Para os casos de "concurso ordinário"184, há ainda a exigência de o administrador judicial ter participado como administrador ou "auxiliar delegado" em outros "concursos ordinários" ou, ao menos, em três "concursos abreviados 185 " já encerrados, exceto se o magistrado considerar "de maneira motivada, idônea a formação e experiência dos que designe" em atenção às características do caso concreto $^{186}$.

Nos Estados Unidos, os administradores judiciais, denominados “trustees", não são escolhidos e fiscalizados pelos "United States Trustees".

Os "U.S. Trustees" são oficiais do governo federal nomeados pelo Procurador geral de Justiça ("U.S. Attorney General”) em cada uma das regiões geográficas nos

\footnotetext{
${ }^{182}$ Art. $27,4,1^{\circ}$, Lei 22/2003.

183 TIRADO, Ignácio. Del nombramiento de los administradores concursales. In: Comentario de la Ley Concursal. ROJO, Ángel e BELTRÁN, Emilio. Tomo I. $1^{a}$ ed. Madrid: Civitas Ediciones, SL, 2.004, p. 586587.

${ }^{184}$ A Espanha adotou o procedimento único de "concurso", o qual pode resultar em um acordo para pagamentos dos credores chamado de "convenio" ou em "liquidación".

${ }_{185}$ Os chamados "concursos abreviados" são procedimentos especiais que podem ser aplicados pelo juiz para os casos em que o devedor tenha menos de 50 (cinquenta) credores e que tanto o ativo como o passivo seja inferior a 5 (cinco) milhões de euros. Este procedimento é utilizado também quando o devedor apresente proposta antecipada de reorganização ou proposta que inclua uma modificação estrutural pela qual se transmita todo seu ativo e passivo para um terceiro, ou, ainda, apresente um plano de liquidação que contenha uma proposta escrita vinculante de compra de unidade produtiva em funcionamento ou quando o devedor tenha cessado completamente sua atividade e não tenha contratos de trabalho em vigor, conforme art. 190 e seguintes da Lei 22/2003.

${ }^{186}$ Art. 27, 4, $2^{\circ}$, Lei 22/2003.
} 
Estados Unidos para um mandato de cinco anos. Em geral, são os "U.S. Trustees" que atuam na seleção do administrador judicial da falência, a não ser nos casos da Carolina do Norte e do Alabama, nos quais existe a figura do "Bankruptcy Administrator". Os "U.S.Trustees" e os "Bankruptcy Admnistrators" desempenham funções semelhantes; são responsáveis por nomear os administradores judiciais e outras tarefas administrativas, tais como a administração dos processos de falência, a manutenção da lista de pessoas qualificadas para o exercício da função de administrador judicial em cada caso específico, o monitoramento das transações e a condução das partes. Devem aprovar e manter uma lista de agências de consultoria de crédito e de instituições para a formação técnicoprofissional dos administradores.

Em todos os casos de falência ("Chapter 7"), um "trustee" é nomeado. Também conhecido como "panel trustee" é escolhido dentre uma lista de administradores judiciais particulares ("panel of private trustees") sob a responsabilidade do U.S. Trustee da região de cada jurisdição e supervisão do Procurador Geral (Attorney General) ${ }^{187}$.

Segundo o "Handbook for Chapter 7 Trustees" do Departamento de Justiça Norte-Americano, o U.S. Trustee deve escolher um "panel trustee" utilizando o "critério cego" ("blind rotation system") de escolha para evitar o favoritismo e que o devedor tente ajuizar a petição em data certa para ter ou evitar determinado administrador judicial, além de eliminar a necessidade de fazer julgamentos individuais sobre as atribuições de caso. A escolha não seguirá tal critério apenas em casos excepcionais, tais como características específicas do caso; necessidade de se alcançar a equidade na distribuição dos processos entre os membros do painel; considerações geográficas, dentre outras ${ }^{188}$.

Jason Kilborn destaca que além de "integridade e bom caráter" e os requisitos gerais a seguir descritos, a única qualificação exigida é que o requerente possua pelo menos um grau de bacharel relacionado à área de negócios ou equivalente, embora os administradores judiciais nomeados quase sempre sejam advogados ou contabilistas ${ }^{189}$. Os requisitos determinados em lei são; i) possuir integridade e bom caráter moral; ii) ser física e mentalmente capaz de executar satisfatoriamente os deveres do administrador judicial;

\footnotetext{
18728 U.S.C. $\$ \S 586(\mathrm{a})(1)$.

${ }^{188}$ U.S. DEPARTMENT OF JUSTICE. Handbook for Chapter 7 Trustees, pag. 2-4/2-5. Disponível em http://www.justice.gov/ust/eo/private trustee/library/chapter07/docs/7handbook0301/Ch7hb0702.pdf. Acesso em 02/05/2.014.

189 KILBORN, Jason. National Report for the United States. In: FABER, Dennis, VERMUT, Niels, KILBORN, Jason e RICHTER, Tomás. Commencement of Insolvency Proceedings. Oxford: Oxford University Press, 2.012, p. 770.
} 
iii) ser cortês e acessível a todas as partes; iv) ser livre de preconceitos contra qualquer indivíduo, entidade, ou grupo de pessoas físicas ou jurídicas; v) não ser relacionado por afinidade ou consanguinidade até primo de primeiro de grau com qualquer funcionário da Secretaria Executiva do "U.S. Trustees" do Departamento de Justiça, ou com qualquer funcionário do escritório do "U.S. Trustees" do distrito em que ele estará atuando; vi) ser membro com uma boa reputação na Ordem dos Advogados ("bar") da alta corte Estado ou do Distrito de Columbia; ou ser um contador público certificado ou titular de um diploma de bacharel de um curso completo de quatro anos de estudo (ou o equivalente) de uma faculdade ou universidade com especialização na área de negócios ou de pelo menos 20 horas semestrais de cursos ligados a negócios, ou possuir um diploma de mestrado ou doutorado em áreas ligadas a negócios; ou ser um estudante de direito sênior (ou seja, do último ano de curso) ou candidato a um mestrado em administração de empresas recomendado pelo reitor da faculdade de direito ou de administração de empresas sob a supervisão direta de um membro de uma faculdade de direito ou de um membro da lista dos "trustees" ou de um membro de um programa estabelecido pela ordem dos advogados local; ou ter experiência equivalente considerada aceitável pelos "U.S. Trustees"; vii) esteja disposto a fornecer relatórios conforme exigido pelos "U.S. Trustees"; e viii) já tenha apresentado uma candidatura, sob juramento, exceto se liberado pelo "U.S. Trustee" ${ }^{\prime 190}$.

Na prática, a atuação dos "trustees" é feita na maioria dos casos por pessoas físicas. Todavia, pessoas jurídicas também poderão atuar como "trustees", desde que as pessoas que forem atuar diretamente no caso concreto atendam os requisitos exigidos para as pessoas físicas ${ }^{191}$.

Nos casos previstos no Capítulo 7, imediatamente após a ordem judicial de sujeição ao procedimento de falência, o "U.S. Trustee" nomeia um administrador interino (“ínterim trustee"), que resida ou tenha escritório no distrito ontem o caso foi ajuizado e que seja qualificado para desempenhar de suas funções, conforme acima já exposto. Jason Kilborn esclarece que, teoricamente, os credores podem eleger outro administrador judicial que não seja o apontado pelo "US Trustee", na eleição conhecida como "341 meeting";

\footnotetext{
19028 Code of Federal Regulations $§ 58.3$ c/c 11 U.S.C. $§ 322$.

191 KILBORN, Jason. National Report for the United States. In: FABER, Dennis, VERMUT, Niels, KILBORN, Jason e RICHTER, Tomás. Commencement of Insolvency Proceedings. Oxford: Oxford University Press, 2.012, p. 770.
} 
todavia, na prática isso não ocorre pela falta dos requisitos previstos em lei ${ }^{192}$ (devem solicitar a eleição os credores que detenham $20 \%$ dos créditos quirografários; pelo menos $20 \%$ desses credores devem comparecer e votar; e uma pessoa qualificada deve receber a maioria dos votos), razão pela qual mantém-se o administrador interino escolhido ${ }^{193}$. Tal administrador será responsável pela verificação preliminar dos bens e negócios do devedor. A função do administrador interino cessará quando for designado ou eleito um administrador permanente ${ }^{194}$, podendo aquele mesmo administrador interino tornar-se administrador permanente se não for eleito ou nomeado outro administrador.

Já para os casos de recuperação judicial (Chapter 11), a designação de um administrador judicial é feita apenas em caráter excepcional ${ }^{195}$, já que, via de regra, o devedor é mantido na posse dos bens (“debtor in possession”), ou seja, detém o controle dos negócios e dos ativos e pode operar no curso ordinário dos negócios sem a prévia aprovação judicial $^{196}$ - ele possui deveres fiduciários em relação aos acionistas e aos credores ${ }^{197}$, sendo um "trustee" de seus próprios ativos ${ }^{198}$. O capítulo da escolha do administrador judicial ("Chapter 11 Trustee Handbook"199) do Departamento de Justiça Norte-Americano é claro no sentido de que o "U.S. Trustee" não escolhe o "chapter 11 trustee" sozinho; é necessária a consulta das envolvidas e a aprovação do nome pelo magistrado ${ }^{200}$. Todavia, o manual também deixa claro que o "U.S. Trustee" fará todas as considerações necessárias e examinará as qualificações individuais de cada candidato. Também é possível a eleição do administrador judicial pelos credores para os casos de recuperação judicial, que será feita nos termos e com os mesmos requisitos previstos para a eleição no caso de falências acima já relacionados ${ }^{201}$. São hipóteses de nomeação de administrador judicial no Capítulo 11 os casos de fraude, incompetência, desonestidade,

\footnotetext{
19211 U.S.C. $\$ \$ 702$.

193 KILBORN, Jason. National Report for the United States. In: FABER, Dennis, VERMUT, Niels, KILBORN, Jason e RICHTER, Tomás. Commencement of Insolvency Proceedings. Oxford: Oxford University Press, 2.012, p. 770-771.

194 11 U.S.C. $\$ \$ 701$.

19511 U.S.C. $\$ \S 1107$.

196 ALBERGOTTI, Robert. Understanding Bankruptcy in the US - a handbook of law and practice. Massachuttes: Blackwell Finance, 1.992, p. 11.

197 SCARBERRY, Mark S., KLEE, Kenneth N., NEWTON, Grant W., e NICKLES, Steve H. Business Reorganization in Bankruptcy: Cases and Materials. 2a . ed. Minnesota: West Group, 2.001, p. 220.

${ }^{198}$ ALBERGOTTI, Robert. Op cit., p. 22.

199 U.S. DEPARTMENT OF JUSTICE. Chapter 11 Trustee Handbook, p. 8. Disponível em http://www.justice.gov/ust/eo/private trustee/library/chapter11/docs/Ch11Handbook-200405.pdf Acesso em $02 / 05 / 2.014$

20011 U.S.C. $\S \S 1104$.

201 U.S.C. $\$ \S 1104$ (b).
} 
má gestão ou por interesse do credor, detentores de participação ou de capital ${ }^{202}$. Ressalta a doutrina que os casos enumerados pelo código são meramente exemplificativos e não exaustivos, podendo o tribunal determinar a nomeação com base em uma razão não prevista no Código. Todavia, não basta a mera evidência de má gestão ou de qualquer outra hipótese; é fundamental a perda da confiança dos credores que, em seus esforços de boa fé, teriam permitido ao devedor a condução de sua própria reorganização ${ }^{203}$.

Outro sujeito que pode estar presente nos casos de reorganização norteamericanos é o inspetor ("examiner") ${ }^{204}{ }^{205}$. Segundo Jason Kilborn, mesmo nos casos de fraude ou má administração, a escolha pelo "examiner" é uma opção mais simples e mais barata do que a nomeação de "trustees" em recuperações judiciais ${ }^{206}$. Ele será sempre nomeado quando não tiver sido um "trustee" na hipótese de o passivo do devedor foi superior a US \$ 5.000.000 (cinco milhões de dólares norte-americanos), excluindo-se alguns créditos ${ }^{207}$ ou a pedido de qualquer parte interessada ou do "U.S. Trustee", com o fim de investigar suspeitas de fraude, desonestidade, incompetência, má conduta, má gestão, ou irregularidade na gestão ${ }^{208}$. Quando designado, incumbirá a ele também qualquer outra obrigação que caiba ao "trustee", desde que assim determinado pelo magistrado $^{209}$.

Embora não seja requisito para a nomeação, o programa do "U.S. Trustee" oferece treinamento contínuo para os "trustees", inclusive para novos administradores, que podem participar de um programa de tutoria com membros mais experientes das listas. Em nível nacional, o programa realiza periodicamente seminários ministrados por "trustees"

\footnotetext{
20211 U.S.C. $\S \S 1104$ (a).

${ }^{203}$ SCARBERRY, Mark S., KLEE, Kenneth N., NEWTON, Grant W., e NICKLES, Steve H. Business Reorganization in Bankruptcy: Cases and Materials. 2a . ed. Minnesota: West Group, 2.001, p. 229-230. 20411 U.S.C. $\$ \S 1104$ (c).

205 O "Bankrupcty Code" ainda prevê a figura do "standing trustee" para os casos do Capítulo 12 (reorganização ou falência de agricultores e pescadores) e Capítulo 13 (reorganização de pessoas físicas). Eles não estão relacionados nas listas como os "panel trustees" e detém um compromisso permanente ("standing appointment") de atuar dentro de uma área geográfica.

206 KILBORN, Jason. National Report for the United States. In: FABER, Dennis, VERMUT, Niels, KILBORN, Jason e RICHTER, Tomás. Commencement of Insolvency Proceedings. Oxford: Oxford University Press, 2.012, p. 771.

207 11 U.S.C. $\S \S 1104$ (b) (2)

${ }^{208} 11$ U.S.C. $\$ \S 1104$ (b) (1)

20911 U.S.C. $\$ \$ 1106$ (b)
} 
mais experientes em seu "National Bankrupcty Training Institute", localizado na Universidade da Carolina do $\mathrm{Sul}^{210}$.

Outro ponto que merece destaque nas legislações estrangeiras analisadas é a necessidade de seguro ou caução a ser prestado pelo administrador judicial, o qual ainda que não seja requisito obrigatório para o acesso, assim é para a investidura e manutenção no cargo, diferentemente do que ocorre na legislação brasileira.

$\mathrm{Na}$ França os administradores judiciais inscritos nas listas estão obrigados a possuir um seguro por meio da "Caixa de Garantia" para os casos de responsabilidade civil em que incorram por negligência ou erros cometidos no exercício de suas funções ${ }^{211}$. No caso do administrador judicial deixar de pagar o seguro, ele é automaticamente expulso da $\operatorname{lista}^{212}$.

O seguro de responsabilidade civil também é obrigatório em Portugal, nos termos do artigo $12^{\circ}, 8$, do Estatuto do Administrador Judicial. O montante do risco coberto deve ser definido em portaria governamental e os administradores judiciais devem remeter cópia dos contratos e respectivas renovações à entidade responsável pelo acompanhamento, fiscalização e disciplina da atividade.

$\mathrm{Na}$ Espanha, o administrador judicial deve comprovar ter "seguro de responsabilidade civil" ou uma "garantia equivalente", no prazo de 05 (cinco) dias seguintes da nomeação ${ }^{213}$. Em 2012, o Decreto Real 1333 regulou de maneira específica, o seguro ou garantia equivalente, merecendo destaque: i) que o dever de seguro recai sobre pessoa física e jurídica (devendo, neste ultimo caso, a cobertura incluir a responsabilidade dos profissionais que atuem em nome da sociedade $)^{214}$; ii) que a soma mínima assegurado deve ser de trezentos mil euros, podendo atingir a cifra de três milhões de euros ${ }^{215}$; iii) a

\footnotetext{
${ }^{210}$ U.S. DEPARTMENT OF JUSTICE. Handbook for chapter 7 Trustees, p. 6-1/6-2. Disponível em http://www.justice.gov/ust/eo/private trustee/library/chapter07/docs/7handbook0301/Ch7hb0702.pdf. Acesso em 02/05/2.014.

${ }^{211}$ Art. L814-3 c/c art. L814-4, "Code de Commerce".

212 DUPOUX, Cécile e NERGUARARIAN, Carole. National Report for France. In: FABER, Dennis, VERMUT, Niels, KILBORN, Jason e RICHTER, Tomás. Commencement of Insolvency Proceedings. Oxford: Oxford University Press, 2.012, p. 298.

${ }^{213}$ Art. 29, 1, Lei 22/2003.

${ }^{214}$ Art. $2^{\circ}$, Decreto Real 1.333/2.012.

${ }^{215}$ Art. $8^{\circ}$, Decreto Real 1.333/2.012.
} 
delimitação temporal (durante o exercício da função ou nos quatro anos seguintes do fim do cargo $)^{216}$, dentre outros.

Nos Estados Unidos, antes de iniciar funções oficiais, o "trustee" deve prestar a caução determinada pelo "U.S. Trustee", perante o tribunal em favor dos Estados Unidos da América, para garantir o fiel cumprimento de suas obrigações ${ }^{217}$.

Por fim, de fundamental importância ressaltarmos também os "Princípios dos Administradores Judiciais" (“Office Holder Principles”) divulgados pelo "European Bank for Reconstruction and Development" (EBRD) com o escopo de "aperfeiçoar a integridade, imparcialidade e eficiência do sistema da lei de insolvência" através de profissionais devidamente qualificados para o exercício do cargo de administradores judiciais, posto que são figuras essenciais no processo e deles depende um bom funcionamento dos sistemas jurídicos, apesar das diferenças existentes entre estes ${ }^{218}$.

Segundo o princípio 1, denominado "Qualificações e Licenças em Geral”, toda legislação deve prever: i) as qualificações do titular do cargo, com "padrões educacionais apropriados, experiência relevante e bons elementos de caráter"; ii) um exame, que englobe a legislação, a prática e outros assuntos relevantes para os candidatos a titular de cargo, como contabilidade, por exemplo; iii) o respectivo licenciamento do candidato, a ser conferido pelo governo ou por um organismo profissional autônomo; iv) um registro público dos titulares licenciados/registrados, com acesso disponível ao público e a todos os tribunais; v) a exigência de educação continuada para os titulares de cargos; vi) a necessidade de renovação periódica da licença; e vii) o licenciamento de pessoas jurídicas. Além disso, o princípio 11 ("Seguro e Caução") estabelece que a lei deva exigir que o titular de cargo mantenha sempre uma caução ou seguro de responsabilidade civil profissional para cobrir terceiros em casos de negligência ou violação do dever ou fraude.

\footnotetext{
${ }^{216}$ Art. $9^{\circ}$, Decreto Real 1.333/2.012.

217 11 U.S.C. $\$ \$ 322$ (a)

${ }^{218}$ EUROPEAN BANK FORM RECONSTRUCTION AND DEVELOPMENT. EBRD Insolvency Office Holder Principles. Disponível em http://www.ebrd.com/downloads/legal/insolvency/ioh_principles.pdf. Acesso em 05/01/2.014.
} 
Destarte, diante da análise do direito comparado, verificamos que os requisitos necessários constantes da LRE estão aquém dos exigidos pelos países com mais sólida e reconhecida experiência em reorganização e liquidação judicial de empresas.

Não obstante a adequada e aplaudida alteração da forma de escolha do administrador judicial feita pela LRE, em comparação com a LF, melhor seria a adoção de critérios mais rígidos para a sua eleição, com a aplicação de listas oficiais composta de profissionais $^{219}$, previamente aprovados por meio de estágios e provas que realmente atestassem os conhecimentos e a prática necessários para a atuação, a fim de que se diminuísse a diferença de qualidade existente entre os nomeados e também se eliminasse a concentração dos casos de maior repercussão financeira nas mãos de poucos e com maior experiência e a escassez (para não se dizer inexistência) de interessados para os processos concursais com poucos ou sem nenhum ativo, como acabamos por ver na prática. A aplicação de treinamentos contínuos, para aperfeiçoamento e atualização de conhecimentos $^{220}$, e a criação de associações de administradores judiciais que visem à defesa, à divulgação e ao controle de regras profissionais e de conduta, também são recomendáveis.

Da mesma forma é desejável a alteração legislativa que preveja a obrigatoriedade de seguro ou caução para as hipóteses da responsabilidade civil por atos do administrador judicial, além do requisito da "idoneidade" financeira, em consonância com as legislações estrangeiras.

\footnotetext{
${ }^{219}$ No Rio de Janeiro, através o Ato Executivo conjunto $\mathrm{n}^{\circ} 52$ de 01 de novembro de 2013 , o Tribunal de Justiça e a Corregedoria Geral de Justiça determinaram que os juízes das varas empresariais juízes enviem à presidência do tribunal "uma lista com nomes de profissionais aptos a exercer a função de administrador judicial, devidamente qualificados, com a comprovação de certificação de conclusão de 'Curso de Especialização em Administração Judicial"”. O primeiro desses cursos (com carga horária total de apenas 24 horas) foi realizado pela Escola Superior de Administração Judiciária (ESAJ) no inicio do ano de 2014, tendo certificado 65 (sessenta e cinco) alunos. Embora seja louvável a precursora tentativa carioca em adotar novas exigências para o ingresso no quadro de administradores judiciais, entendemos que a inclusão de nomes em uma lista após a realização de um curso tão sucinto não conferirá a aptidão total e necessária que o administrador judicial requer. Como já exposto, estágios comprobatórios e exames para admissão nas citadas listas são essenciais, sob pena de mais uma vez repetirmos a malfadada experiência que tivemos com as listas de síndicos conforme determinava a Lei 859 de 1.902.

${ }^{220}$ Neste sentido, destacamos a criação do primeiro instituto com a finalidade de aperfeiçoamento de administradores judiciais e profissionais da área, "IBAJUD - Instituto Brasileiro de Administração Judicial", com sede em São Paulo, em 07/06/13.
} 


\subsubsection{Investidura.}

O administrador judicial deve ser nomeado pelo juiz, no momento do deferimento do processamento da recuperação judicial ${ }^{221}$ ou na sentença que decretar a falência ${ }^{222}$.

Dispõe o artigo 33 da LRE que "logo que nomeado", o administrador judicial será intimado pessoalmente para, em quarenta e oito horas, assinar, na sede do juízo, o termo de compromisso. Não cumprido o prazo estipulado em lei, o juiz deverá nomear outro profissional ou empresa especializada.

Conforme destaca Paulo Fernando Campos Salles de Toledo, embora seja um ato simples, não se trata de formalismo inútil. A assinatura do termo confere o marco inicial a partir do qual o administrador passa a desempenhar o cargo e assumir todas as responsabilidades a ele inerentes ${ }^{223}$.

$\mathrm{Na}$ hipótese de o encargo ser exercido por pessoa jurídica, deverá constar no termo o nome do profissional responsável pela condução do processo, que não poderá ser substituído sem autorização judicial ${ }^{224}$, haja vista que o exercício da função é de caráter essencialmente individual $^{225}$.

\subsection{Impedimentos.}

Ao lado dos requisitos de nomeação explicitados no "caput" do artigo 21, a LRE também traz as hipóteses de impedimentos, que devem ser verificadas pelo magistrado para que proceda à nomeação do administrador judicial.

\footnotetext{
${ }^{221}$ Art. 52, inc. I, LRE.

${ }^{222}$ Art. 99, inc. IX, LRE.

${ }^{223}$ TOLEDO, Paulo Fernando Campos Salles de. In: TOLEDO, Paulo Fernando Campos Salles de, e ABRÃO, Carlos Henrique (coord.). Comentários à Lei de Recuperação de Empresas e Falência. $4^{\mathrm{a}}$. ed. São Paulo: Saraiva, 2.010, p. 139.

${ }^{224}$ Art. 21, § único, LRE.

${ }^{225}$ TOLEDO, Paulo Fernando Campos Salles de. In: TOLEDO, Paulo Fernando Campos Salles de, e ABRÃO, Carlos Henrique (coord.). Comentários à Lei de Recuperação de Empresas e Falência. 4a. ed. São Paulo: Saraiva, 2.010, p. 104.
} 
Consoante determina o artigo 30, "caput", da LRE, a nomeação do administrador judicial não poderá recair sobre aquele que no exercido o cargo de administrador nos últimos cinco anos: i) foi destituído ${ }^{226}$; ii) deixou de prestar contas dentro dos prazos estipulados pela lei; ou iii) teve a prestação de contas desaprovada. As mesmas situações impeditivas também estavam presentes na legislação anterior; todavia a novidade está na limitação temporal dos cinco anos a contar da ocorrência dos fatos supra descritos. Também não poderá ser nomeado para o cargo aquele que tiver relação de parentesco ou afinidade até o terceiro grau com o devedor, seus administradores (e não só representantes legais, como dispunha a LF), controladores ou representantes legais ou deles for amigo, inimigo ou dependente, conforme estipula o parágrafo primeiro do supra citado dispositivo legal.

Note-se que da leitura do Provimento 797/03 do Conselho Superior de Magistratura do Tribunal de Justiça de São Paulo, verificamos, ainda, que o administrador judicial atuante no estado bandeirante não poderá ter vinculo de parentesco sanguíneo, por afinidade ou civil por linha descendente, ascendente ou colateral, até quarto grau, com o juiz e servidores da unidade judiciário em que $\operatorname{atuar}^{227}$.

A legislação brasileira silencia sobre a possibilidade ou não de o administrador judicial ser estrangeiro. Tampouco dispõe se os impedimentos existentes para os administradores nas sociedades de responsabilidade limitada ${ }^{228}$ e nas sociedades anônimas $^{229}$ são aplicáveis aos administradores judiciais. Da mesma forma, não há dispositivo legal que esclareça sobre a possibilidade ou não de o administrador judicial exercer outra função (como, por exemplo, ser comerciante, ou administrador ou diretor de sociedades em geral), ou, ainda atuar neste cargo em empresas concorrentes do mesmo ramo, tendo acesso a informações privilegiadas.

Não obstante o silêncio da LRE, caberá ao magistrado ponderar as características de cada candidato a administrador judicial a fim de garantir a imparcialidade e independência do órgão.

\footnotetext{
${ }^{226}$ Note-se que o impedimento é apenas para a hipótese de destituição e não de substituição.

${ }_{227}$ Art. $2^{\circ}$, 2, Provimento 797/03 do Conselho Superior de Magistratura do Tribunal de Justiça de São Paulo.

${ }^{228}$ Art. $1011, \S 1^{\circ}, \mathrm{CC}$.

229 Art. 146 e 147, LSA.
} 
Vera Helena de Mello Franco e Rachel Sztajn destacam que "o elenco arrolado nesta norma [art. 30] não é taxativo". Desta forma, mesmo não havendo proibição expressa na LRE, não podem ser administradores judiciais os incapazes, de acordo com os artigos $3^{\circ}$ e $4^{\text {o e }}$ 972, todos do Código Civil; os insolventes (pela falta de idoneidade financeira); os credores ou terceiros com interesses contrários ao devedor em recuperação ou à massa falida; ou, ainda, que ocupem cargos públicos ${ }^{230}$. Também não poderão exercer a função de administrador judicial, pelos menos quando assumirem atos de gestão da empresa em recuperação judicial ou mantiverem as atividades da falida, aqueles que estejam impedidos por lei de serem administradores de sociedade.

Na hipótese de o administrador judicial ser pessoa jurídica, os impedimentos de ordem pessoal deverão ser aplicados aos seus administradores, controladores ou representantes legais, e também ao profissional que assinou o termo de compromisso ${ }^{231}$.

No estudo do direito comparado, verificamos um rigor muito maior no tratamento dado às incompatibilidades e aos impedimentos do exercício do cargo de administrador judicial.

O Código de Comércio francês estabelece que o exercício da atividade administrador judicial é incompatível com o exercício de qualquer outra profissão (com exceção da profissão de advogado) e de todas as atividades de natureza comercial. Também não poderá ser sócio solidário em qualquer tipo de sociedade, a menos, obviamente, que essas sociedades tenham por objeto o exercício da função de administrador judicial. Somente é permitido o exercício da atividade de consultoria, desde que exercidas em caráter acessório, além das funções de "mandataire ad hoc" e “conciliateur" previstas nos artigos L 611-3 e L611-6 do "Code de Commerce"232.

$\mathrm{Na}$ França, além dos impedimentos por parentesco, o administrador judicial não pode, nos cinco últimos anos precedentes, ter recebido a qualquer título, direta ou

\footnotetext{
${ }^{230}$ FRANCO, Vera Helena de Mello e SZTAJN, Rachel. Falência e Recuperação da Empresa em Crise. $1^{\text {a }}$. ed. Rio de Janeiro: Elsevier, 2008, p. 61.

${ }^{231}$ CAMPINHO, Sérgio. Falência e Recuperação de Empresa: O novo regime da insolvência empresarial. $6^{\mathrm{a}}$ ed. Rio de Janeiro: Renovar, 2.012, p. 61

${ }^{232}$ Artigo L811-10, "Code de Commerce".
} 
indiretamente, retribuição ou pagamento da pessoa em crise ou de qualquer pessoa a ela ligada, nem ter nenhum interesse no mandato de administrador judicial ${ }^{233}$.

O Estatuto português do administrador judicial (Lei 22/13) estabelece de maneira pormenorizada, em seu artigo $4^{\circ}$, as “incompatibilidades, impedimentos e suspeições”. O administrador judicial português está sujeito aos impedimentos e suspeições aplicáveis aos juízes e às regras gerais sobre incompatibilidades aplicáveis aos "titulares de órgãos sociais das sociedades". Ele também não pode integrar, durante o exercício de suas funções, órgãos sociais ou ser dirigente de empresas que tenham atividades semelhantes às das empresas em recuperação (processo especial de revitalização ${ }^{234}$ ) ou da massa falida. Igualmente não pode, por si ou através de terceiro, atuar como "membro de órgãos sociais ou dirigentes" de empresas em que tenham exercido as suas funções ou ter desempenhado alguma função na dependência hierárquica ou funcional dos gerentes da sociedade, antes do período de três anos do exercício daquelas funções ou atividades. Por fim, o administrador judicial, seus cônjuges e parentes consanguíneos ou por afinidade até o $2^{\circ}$ (segundo) grau em linha reta ou colateral não podem ser titulares de participações societárias das empresas em recuperação ou falidas.

O direito espanhol também trata de forma minuciosa as causas de inelegibilidade igualmente estabelecendo uma divisão em três categorias: incapacidades, incompatibilidades e proibições, conforme dispõe o artigo 28 da Lei 22/2003. Referido dispositivo legal é expresso no sentido de proibir a nomeação de administradores judiciais daqueles que: i) não possam ser administradores ou diretores de responsabilidade limitada ou anônima; ii) hajam prestado qualquer tipo de serviço profissional ao devedor ou a pessoas especialmente relacionadas com este nos últimos 3 (três) anos; iii) já tenham sido designados administradores judiciais pelo mesmo juiz em 3 (três) processos nos últimos 2 (dois) anos anteriores, sempre que hajam mais profissionais disponíveis nas listas oficiais $^{235}$; v) tiverem sido afastados do cargo de administrador judicial nos 2 (dois) anos

${ }^{233}$ FRANCO, Vera Helena de Mello e SZTAJN, Rachel. FRANCO, Vera Helena de Mello e SZTAJN, Rachel. Falência e Recuperação da Empresa em Crise. 1ª ed. Rio de Janeiro: Elsevier, 2.008, p. 58.

${ }^{234}$ Art. $1^{\circ}, 2$, e art. 17 e ss., CIRE.

${ }^{235}$ Esta proibição não se aplica às pessoas jurídicas, cf. art. 28, 2, Lei 22/2.003. 
anteriores; vi) foram inabilitados por sentença de desaprovação de contas em processo anterior $^{236}$; dentre outros.

Nos Estados Unidos da América, não poderá ser administrador judicial aquele que tenha conflito de interesses ("conflict of interest") ou ausência de desinteresse ("lack of disinterestedness"). Da leitura do seção 101 (14) do "Bankrupcty Code", que define "pessoa desinteressada" (“disinterested person”), podemos concluir que não poderá ser "trustee" aquele: (i) que seja credor, detentor de participação societária ou um insider; (ii) que é ou tenha sido no prazo de dois anos antes da apresentação do inicio da ação um conselheiro, diretor ou empregado do devedor; e (iii) que tenha interesse materialmente adverso ao interesse da companhia ou de qualquer classe de credor ou detentor de participação societária, decorrente de qualquer direta ou indireta relação, conexão ou interesse ligado ao investidor ou qualquer outra possível razão. Todavia, referido artigo não contempla um rol fechado, podendo também ser considerado conflito de interesses ou ausência de desinteresse qualquer outra hipótese, inclusive no que diz respeito a sócios ou a sociedade da qual pertença o administrador judicial ${ }^{237}$.

\subsection{Deveres e atribuições.}

A exemplo da antiga LF, a legislação atual enumera uma longa série de atribuições e deveres impostos ao administrador judicial. Grande parte de suas funções estão elencadas no artigo 22 da LRE, tanto para a recuperação judicial como para a falência. Todavia, o rol não é taxativo já que também toma o cuidado de enunciar a existência de "outros deveres", previstos em artigos diversos da LRE.

Além disso, como se verá no presente estudo, as atribuições do administrador judicial não se limitam às constantes de forma explícita na LRE, eis que este órgão auxiliar da justiça e de confiança do juiz deve exercer todas as funções necessárias para

\footnotetext{
${ }^{236}$ Trata-se de uma inabilitação temporal, durante o período determinado na sentença judicial, que não poderá ser inferior a 6 (seis) meses e nem superior a 2 (dois) anos, nos termos do art. 181 da Lei 22/2.003.

${ }^{237}$ U.S. DEPARTMENT OF JUSTICE. Handbook for chapter 7 Trustees, pag. 5-1/5-2. Disponível em http://www.justice.gov/ust/eo/private trustee/library/chapter07/docs/7handbook0301/Ch7hb0702.pdf. Acesso em 02/05/2.014.
} 
desempenhar o cargo assumido da maneira mais eficaz e completa possível. Consoante ensina Paulo Fernando Campos Salles de Toledo, "o administrador judicial, ao assumir suas funções, comprometeu-se a 'bem e fielmente desempenhar o cargo', com 'as responsabilidades a ele inerentes'. Assim, tudo o que estiver compreendido no bom exercício das funções, insere-se nos deveres do administrador judicial"238_ ${ }^{239}$.

Verifiquemos, pois, as principais atribuições do administrador judicial constantes na LRE.

\subsubsection{Deveres e atribuições legais comuns.}

Podemos dividir em três grupos as competências comuns do administrador judicial $^{240}$. O primeiro grupo refere-se ao direito à informação dos credores e do administrador $^{241}$, melhor explicitado nos tópicos 3.4.1.1 a 3.4.1.4 infra. O segundo diz respeito à verificação e organização dos $\operatorname{créditos}^{242}$, conforme tópico 3.4.1.5 infra. E o terceiro se traduz na competência de zelar pela regularidade do processo e de adotar as medidas necessárias para que suas funções sejam exercidas da forma mais eficiente possível $^{243}$, como será demonstrado nos tópicos 3.4.1.6 a 3.4.1.8 infra.

\subsubsection{Envio de correspondências aos credores.}

${ }^{238}$ TOLEDO, Paulo Fernando Campos Salles de. In: TOLEDO, Paulo Fernando Campos Salles de, e ABRÃO, Carlos Henrique (coord.). Comentários à Lei de Recuperação de Empresas e Falência. $4^{\mathrm{a}}$. ed. São Paulo: Saraiva, 2.010, p. 107.

${ }^{239}$ Também neste sentido, Waldo Fazzio Júnior: “Também, é muito modesto o artigo referido ao rezar que o administrador judicial deve exercer as funções que lhe são atribuídas pela LRE. Deveria, para ser fiel à exata dimensão da administração da falência, dizer que o administrador judicial deve exercer todas as funções necessárias para que a execução concursal realize as finalidades legais. É que, em diversas situações, o administrador judicial terá algumas margens de discricionariedade para eleger a conduta mais adequada, no interesse da massa. É certo que o fará, sob supervisão judicial, mas esta não tem o poder de vinculação capaz de prever todas as possibilidades de solução para os problemas emergentes dos conflitos naturais entre os interesses dos credores, o interesse do devedor e o interesse público. Por isso, o administrador judicial não é singelo executor material, mas qualificado regente da falência." FAZZIO JÚNIOR, Waldo. Lei de Falência e Recuperação de Empresas, 4ª ed., São Paulo: Atlas, 2.008, p. 329.

240 PENTEADO, Mauro Rodrigues. In: CÔRREA-LIMA, Osmar Brina e LIMA, Sérgio Mourão Corrêa (coord.). Comentários à Nova lei de Falência e Recuperação de Empresas: Lei $n^{\circ} 11.101$, de 09 de fevereiro de 2005. $1^{\mathrm{a}}$ ed. Rio de Janeiro: Forense. 2.009, p.176 e ss.

${ }^{241}$ Art. 22, inc. I, al. "a" a "d", LRE.

${ }^{242}$ Art. 22, inc. I, al. "e" e "f", LRE.

${ }^{243}$ Art. 22, inc. I, al. "g" a "i", LRE. 
O administrador judicial deve encaminhar aos credores constantes das listas

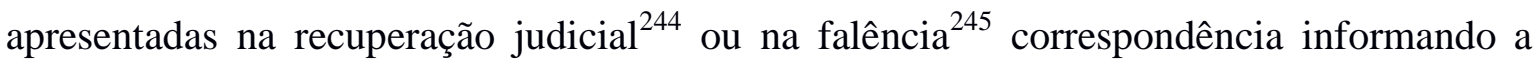
data do pedido de recuperação judicial ou da decretação da falência, bem como a natureza, o valor e a classificação de seu crédito ${ }^{246}$. Deverá, obviamente, informar, ainda que não seja uma determinação legal, o número do processo, a vara e o foro e fórum no qual se encontra, sendo também conveniente declinar o endereço e telefone do administrador judicial.

Tal correspondência é a única obrigatória a ser feita pelo administrador judicial e tem como finalidade dar conhecimento aos credores da recuperação judicial ou da falência do devedor, para que venham tomar as medidas necessárias à defesa de seus interesses $^{247}$.

Embora não seja exigência legal, entendemos ser conveniente que a correspondência também indique o prazo de quinze dias para a interposição de eventual divergência na hipótese de o credor discordar da forma que seu crédito foi apresentado pelo devedor, conforme prescreve o artigo $7^{\circ}$, parágrafo $1^{\circ}$ da LRE. Note-se que a contagem do prazo aqui citado inicia-se da publicação do edital, possuindo a correspondência enviada pelo administrador judicial caráter unicamente informativo.

Um grande problema prático com o qual se deparam os administradores judiciais é o fato de os devedores não fornecerem a relação integral de todos os seus credores e/ou seus endereços corretos e atualizados. Não compete ao administrador judicial a busca de novos credores e/ou endereços, até porque não há exigência legal de recebimento da correspondência por todos os credores, tendo em vista às publicações dos editais previstos em lei.

A legislação não determina a forma de envio da correspondência, mas tendo em vista que cabe ao devedor indicar apenas o "endereço" do credor ("ex vi" do disposto no artigo 51, inciso III e artigo 99, caput, inciso III, LRE), entende-se que a

\footnotetext{
${ }^{244}$ Art. 51, "caput", inc. III, LRE.

${ }^{245}$ Art. 99, "caput", inc. III e art. 105, “caput”, inc. II, LRE.

${ }^{246}$ Art. 22, inc. I, al. "a”, LRE.

${ }^{247}$ VERÇOSA, Haroldo Malheiros Duclerc. In: SOUZA JUNIOR, Francisco Satiro de, e PITOMBO, Antônio Sérgio de A. Moraes. (coord.). Comentários à Lei de Recuperação de Empresas e Falência. Lei 11.101/2005. - Artigo por Artigo. $2^{\mathrm{a}}$ ed. São Paulo: Revista dos Tribunais, 2.007, p. 169.
} 
correspondência deva ser enviada por carta e, de preferência, com aviso de recebimento. Note-se que para os processos que tramitam exclusivamente pelo meio eletrônico, nos termos da Lei 11.419/06, questiona-se a possibilidade de envio dessa correspondência por “email". Desconhecemos, na prática, a existência de processos concursais com intimações aos credores por via eletrônica. Não obstante a rapidez e a agilidade conferidas pela “internet”, acreditamos que ainda por um longo período as intimações deverão ser feitas por carta e com aviso de recebimento, inclusive em prol da segurança jurídica, até porque não podemos olvidar que a LRE vige para todo o País e o acesso à tecnologia não é uma realidade para toda população brasileira.

A LRE também não dispõe sobre o prazo para o envio dessa correspondência. Todavia, entende-se que ela deva ser recebida antes do edital de convocação previsto no artigo $52^{\circ}$, parágrafo $1^{\circ}$ e no artigo 99 , parágrafo único, ambos da LRE, para as hipóteses de recuperação judicial e de falências, respectivamente.

\subsubsection{Fornecimento de informações solicitadas pelos credores interessados.}

A LRE não estabelece o prazo, mas é clara no sentido de que o administrador judicial deve, com presteza, fornecer as informações solicitadas pelos credores interessados ${ }^{248}$.

Note-se que não é qualquer credor que deve ser atendido; a LRE é expressa ao falar em "credor interessado", ou seja, as informações devem ser dadas apenas para aqueles que tenham algo a reclamar na recuperação judicial ou na falência, detendo, pois, interesse jurídico no processo.

Da mesma forma, não é qualquer informação que deve ser prestada pelo administrador judicial: somente as "informações pertinentes aos interesses em jogo"249 devem ser fornecidas, estando totalmente excluídos demais esclarecimentos, como por exemplo, dados confidenciais do devedor em recuperação judicial ou falido. Ademais, o

\footnotetext{
${ }^{248}$ Art. 22, inc. I, al. "b”, LRE.

${ }^{249}$ VERÇOSA, Haroldo Malheiros Duclerc. In: SOUZA JUNIOR, Francisco Satiro de, e PITOMBO, Antônio Sérgio de A. Moraes. (coord.). Comentários à Lei de Recuperação de Empresas e Falência. Lei 11.101/2005. - Artigo por Artigo. $2^{\mathrm{a}}$ ed. São Paulo: Revista dos Tribunais, 2.007, p. 168.
} 
administrador judicial não é responsável por informar mero andamento processual, competindo aos credores a busca dessas informações seja através do site do tribunal competente, seja mediante a contratação de assessoria jurídica adequada para tal fim caso não detenham conhecimentos jurídicos necessários para tanto.

\subsubsection{Fornecimento de extratos de livros do devedor.}

Para fundamentarem suas habilitações ou impugnações de crédito, os credores que assim entenderem necessário podem solicitar extratos contábeis ao administrador judicial $^{250}$; e, como ressaltam Vera Helena de Mello Franco e Raquel Sztajn, “(...) aqui têm-se em vista não somente os livros comerciais obrigatórios (artigos 1.180 e 1.185 do CCB), mas, igualmente, os facultativos, os fiscais e aqueles cuja existência se impõe em virtude da Justiça do Trabalho)." ${ }^{251}$. Referidos extratos também deverão ser utilizados pelo próprio administrador judicial em suas manifestações, nas impugnações de crédito ou habilitações retardatárias, nos termos do artigo 12, parágrafo único da LRE.

Tendo em vista que na recuperação judicial o administrador judicial apenas fiscaliza as atividades do devedor, sendo a sua gestão excepcional e "pro tempore", os livros contábeis não estarão sob sua guarda. Por isso, consoante alerta Mauro Rodrigues Penteado, deve-se interpretar o mandamento contido no artigo 22, inciso I, alínea "c", da LRE, "no sentido de que o administrador judicial pode exigir do devedor que cumpra a providência, a fim de que possa ele conferir e entregar os extratos aos credores", sob pena de ser afastado da condução de sua atividade empresarial, nos termos do artigo 64, inciso $\mathrm{V}$, da lei.

Já na falência, esta função ressalta ainda mais a importância do administrador judicial ser "pessoa jurídica especializada" ou, ainda que pessoa física, a necessidade de contar com prepostos ou auxiliares aptos e com conhecimento e experiência nas áreas empresarial e contábil. Explica-se: a realização de extratos dos livros da sociedade

\footnotetext{
${ }^{250}$ Art. 22, inc. I, al. “c”, LRE.

251 FRANCO, Vera Helena de Mello e SZTAJN, Rachel. FRANCO, Vera Helena de Mello e SZTAJN, Rachel. Falência e Recuperação da Empresa em Crise. 1ª ed. Rio de Janeiro: Elsevier, 2.008, p. 62.
} 
demanda da análise de livros contábeis, a qual muito provavelmente não poderá ser feita por administrador judicial que não detenha conhecimentos contábeis para tanto, além de ser esta prerrogativa dos profissionais de contabilidade, de acordo com a Resolução do Conselho Federal de Contabilidade $\mathrm{n}^{\mathrm{o}}$ 560/83 $3^{252}$.

\subsubsection{Prerrogativa de exigir informações.}

Se, por um lado, a LRE determina que o administrador preste as devidas informações aos interessados, de outro lhe confere o direito de exigir todas as informações dos credores ou do próprio devedor (ou de seus administradores), que sejam necessárias ao deslinde da recuperação judicial ou da falência ${ }^{253}$.

Trata-se de prerrogativa do administrador judicial para que possa desempenhar com a eficácia necessária as suas funções; e, se houver recusa, poderá solicitar que o juiz intime aquelas pessoas para que compareçam à sede do juízo, e prestem as informações pessoalmente na sua presença e por escrito, sob pena de desobediência ${ }^{254}$. A falta da prestação das informações solicitadas pelo administrador judicial é causa de afastamento do devedor e de seus administradores da administração da empresa, nos termos do artigo 64, inciso V, da LRE.

\subsubsection{Verificação dos créditos, elaboração da relação de credores, consolidação do quadro-geral de credores e publicação de editais.}

$\mathrm{Na}$ tentativa de agilizar os andamentos dos processos concursais, a LRE inovou ao atribuir ao administrador judicial o dever de verificar os créditos contra a empresa em recuperação judicial ou falida, com base nos livros contábeis e documentos

\footnotetext{
252 SANTOS, José Vanderlei Masson dos. Da atuação do perito contador na Nova lei de Falências e Recuperação de Empresas. In: DELUCCA, Newton, e DOMINGUES, Alessandra de Azevedo (coord.). Direito Recuperacional. Aspectos teóricos e práticos. 1a ed. São Paulo: Quartier Latin, 2.012, p. 348. ${ }^{253}$ Art. 22, inc. I, al. “d”, LRE.

${ }^{254}$ Art. $22, \S 2^{\circ}$, da LRE.
} 
comerciais e fiscais do devedor, além dos fornecidos pelos credores, com o auxilio de profissionais especializados, caso seja necessário e com a prévia autorização judicial ${ }^{255}$.

No ato da interposição do pedido de recuperação judicial ${ }^{256}$ e 05 (cinco) dias após a decretação da sentença de falência ${ }^{257}$, o devedor deverá apresentar relação nominal dos seus credores, com a indicação de seus endereços, natureza, classificação e valores dos créditos $^{258}$.

Referida lista de credores será publicada por edital, nos termos do artigo 52, parágrafo $1^{\circ}$ e do artigo 99, parágrafo único, respectivamente, ambos da LRE, quando, então, terá inicio o que a doutrina passou a chamar de "fase administrativa" da verificação dos créditos pelo administrador judicial. Os credores terão prazo de 15 (quinze) dias para apresentar suas habilitações ou divergências, diretamente ou através de advogado, ao administrador judicial $^{259}$.

Verificamos aqui um dos grandes momentos de atuação do administrador judicial ao qual, muitas vezes, não é dada a devida importância. O administrador judicial deverá analisar de forma minuciosa, individual e pormenorizada tanto a contabilidade, a relação de débitos e a documentação do devedor, como as habilitações e divergências e respectivos documentos apresentados pelo credor. Ele será o responsável pela conferência, ao menos nesta primeira fase, da regularidade e também licitude ${ }^{260}$ dos créditos listados, para futura consolidação de um quadro geral de credores que expresse a verdadeira situação do passivo do devedor.

Ainda que caiba ao administrador judicial a análise e a classificação dos créditos, nesta fase administrativa não conseguimos vislumbrar nenhum ato de discricionariedade deste órgão auxiliar da justiça. Ele deverá analisar de forma técnica, objetiva e detalhada todos os documentos apresentados e a contabilidade do devedor, e poderá, inclusive, vir a responder pelos prejuízos causados aos credores, ao devedor e à

\footnotetext{
${ }^{255}$ Art. $7^{\circ}$, “caput”, LRE.

${ }^{256}$ Art. 51, LRE.

${ }^{257}$ Art. 99, inc. III, LRE.

${ }^{258} \mathrm{Na}$ hipótese de o falido não apresentar a relação (passível, inclusive, de ser apenado por crime de desobediência), deverá o administrador judicial fazê-la, com base na documentação e livros disponíveis. ${ }^{259}$ Art. $7^{\circ}, \S 1^{\circ}$, LRE.

${ }^{260}$ Dizemos licitude já que é possível a inclusão de créditos falsos, que poderão vir a caracterizar a pratica de crimes falimentares (artigos 168, 171, 175, dentre outros, da LRE).
} 
massa falida ${ }^{261}$, caso não apure ou admita “créditos não condizentes com os livros e documentos sobre os quais se baseiam" ${ }^{262}$. Por tais razões, discordamos do entendimento de Alfredo Luiz Kugelmas e Gustavo Henrique Sauer de Arruda Pinto, que defendem a possibilidade de verificação dos créditos por amostragem nos casos em que o número de credores seja expressivo ${ }^{263}$.

Com base nessa análise e em 45 (quarenta e cinco) dias contados do fim do prazo de apresentação de habilitações ou divergências, o administrador judicial deverá apresentar "parecer" 264 (geralmente acompanhado do parecer técnico de seus auxiliares contábeis) com suas justificativas pela aceitação ou não das habilitações e/ou divergências, bem como uma nova relação de credores, com as alterações que entender necessárias. Deverá publicar novo edital, incluindo nele a indicação do local, horário e prazo comum para que os credores, o devedor e/ou seus sócios, e o Ministério Público ${ }^{265}$ tenham acesso aos documentos que serviram de fundamento para a elaboração dessa nova lista ${ }^{266}$. Com a publicação deste novo edital com a lista nominativa de credores, encerra-se a fase administrativa de verificação dos créditos.

A fase contenciosa inicia-se com a apresentação de impugnação à lista de credores pelas pessoas acima arroladas ${ }^{267}$ diretamente ao magistrado do processo concursal, no prazo de 10 (dez) dias contados da publicação do edital. Também poderão ser apresentadas ao juízo habilitações de crédito que não foram apresentadas na fase administrativa ${ }^{268}$. As habilitações e as impugnações serão julgadas nos termos dos artigos

\footnotetext{
${ }^{261}$ Art. 32, LRE.

${ }^{262}$ BALBINO, Paulo de Carvalho. In: CÔRREA-LIMA, Osmar Brina e LIMA, Sérgio Mourão Corrêa (coord.). Comentários à Nova lei de Falência e Recuperação de Empresas: Lei $n^{\circ} 11.101$, de 09 de fevereiro de 2005. $1^{\mathrm{a}}$ ed. Rio de Janeiro: Forense, 2.009, p.119.

${ }^{263}$ KUGELMAS, Alfredo Luiz, e ARRUDA PINTO, Gustavo Henrique Sauer de. Administrador judicial na recuperação judicial: Aspectos Práticos. In: DELUCCA, Newton de, e DOMINGUES, Alessandra de Azevedo (coord.). Direito Recuperacional. Aspectos teóricos e práticos. $1^{\mathrm{a}}$ ed. São Paulo: Quartier Latin, 2.009, p. 207-208.

${ }^{264}$ Segundo Paulo Fernando Campos Salles de Toledo, a LRE se refere a "parecer" pois "espera-se que o administrador, como auxiliar do juízo, seja isento". TOLEDO, Paulo Fernando Campos Salles de. In: TOLEDO, Paulo Fernando Campos Salles de, e ABRÃO, Carlos Henrique (coord.). Comentários à Lei de Recuperação de Empresas e Falência. 4a. ed. São Paulo: Saraiva, 2.010, p. 87

${ }^{265}$ Note-se que o prazo para o Ministério Público não é o comum previsto nesse art. $8^{\circ}$ e também não dispensa intimação pessoal. Da mesma forma, não precisa o "Parquet" deslocar-se até o administrador judicial como faz parecer o dispositivo legal citado. $\mathrm{O}$ administrador judicial deve encaminhar ao Ministério Público toda a documentação necessária, em face de suas prerrogativas funcionais.

${ }^{266}$ Art. $7^{\circ}, \S 2^{\circ}$, LRE.

${ }^{267}$ Art. $8^{\circ}$, LRE.

${ }^{268}$ As habilitações e impugnações apresentadas fora dos prazos dos arts. $7^{\circ}$ e $8^{\circ}$ da LRE, serão recebidas como retardatárias, com restrição ao direito de voto na assembleia-geral de creditos nos casos de
} 
10 e 15, respectivamente, da LRE, encerrando-se, assim, esta segunda fase de verificação dos créditos.

Com base na segunda lista de credores apresentada ${ }^{269}$ e nas decisões judiciais proferidas nas impugnações e habilitações ${ }^{270}$ proferidas, o administrador judicial deverá elaborar a consolidação do quadro-geral de credores, a ser homologado pelo magistrado, mencionando a importância e a classificação de cada crédito na data do requerimento da recuperação judicial ou da decretação da falência.

Devidamente assinado pelo juiz e pelo administrador judicial, o quadro-geral de credores deverá ser juntado aos autos. Competirá, ainda, ao administrador judicial a publicação do referido quadro-geral de credores, no órgão oficial, no prazo de 05 (cinco) dias, "contado da data da sentença que houver julgado as impugnações" (artigo 18, parágrafo único $)^{271}$. Note-se que o administrador judicial dificilmente conseguirá cumprir prazo tão exíguo haja vista: i) que cada impugnação será objeto de uma sentença e, muito dificilmente, todas as sentenças serão prolatadas em um único dia; ii) que muitas dessas sentenças serão objeto de recurso e, portanto, não terão transitado em julgado no prazo acima referido; iii) os trâmites burocráticos e o acúmulo de serviços dos cartórios judiciais. Por isso, o melhor entendimento dado pela doutrina é no sentido de que este prazo apenas passa a contar da data do julgamento da última impugnação transitada em julgado ${ }^{272}$.

O quadro-geral de credores somente será alterado com a exclusão ou alteração de classificação ou valor de qualquer crédito, na hipótese de descoberta de falsidade, dolo, simulação, fraude, erro essencial ou do aparecimento de documentos ignorados na época do julgamento do crédito ou da inclusão no quadro-geral de credores, mediante ação própria (ação rescisória ou de anulação de atos judiciais). Verifica-se, assim, mais uma

recuperações judicial e com a perda de direito a rateios eventualmente realizados e sujeitos ao pagamento de custas, nos termos do art. 10 da LRE.

${ }^{269}$ Art. $7^{\circ}, \S 2^{\circ}$, LRE.

${ }^{270}$ As habilitações de crédito retardatárias, desde que apresentadas antes da homologação do quadro-geral de credores, serão recebidas como impugnação e serão processadas nos termos dos art. 13 a 15 da LRE, conforme dispõe o art. $10, \S 5^{\circ}$, do referido diploma legal.

${ }^{271}$ A única hipótese de dispensa da publicação deste edital se dá na hipótese de inexistência de habilitações ou impugnações, ocasião em que o juiz homologará a segunda relação de credores apresentada pelo administrador judicial, como quadro-geral de credores (art. 14, LRE).

${ }^{272}$ TOLEDO, Paulo Fernando Campos Salles de. In: TOLEDO, Paulo Fernando Campos Salles de, e ABRÃO, Carlos Henrique (coord.). Comentários à Lei de Recuperação de Empresas e Falência. $4^{\mathrm{a}}$ ed. São Paulo: Saraiva, 2.010, p. 97. 
atribuição do administrador judicial: requerer a alteração ou exclusão do crédito, caso constate qualquer uma das hipóteses acima arroladas, conforme comando expresso da $\mathrm{LRE}^{273}$.

\subsubsection{Requerimento de convocação e presidência da assembleia-geral de credores.}

O administrador judicial deverá requerer ao juiz a convocação de assembleiageral dos credores, prevista no artigo 35 da LRE ${ }^{274}{ }_{-}^{275}$. Todavia, outras assembleias podem vir a ocorrer já que a parte final da alínea "g" do inciso I do artigo 22 da LRE faculta ao administrador judicial a solicitação de sua convocação sempre que "entender necessária", cabendo ao juiz decidir pelo deferimento ou não.

Caberá ao administrador judicial presidir as assembleias previstas na $\mathrm{LRE}^{276}$, exceto nas hipóteses de deliberação sobre o pedido de seu afastamento ou em que haja incompatibilidade deste, ocasiões em que serão presididas pelo credor presente que seja titular de maior crédito $^{277}$. Note-se que o pedido de substituição do administrador judicial pode ser feito por qualquer credor, independentemente de realização de assembleia, cabendo única e exclusivamente ao magistrado a decisão final. Aliás, como aponta Erasmo Valladão Azevedo e Novaes França, a hipótese de deliberação em assembleia sobre o afastamento do administrador remanesceu na lei "em razão de um cochilo do Executivo, ao exercer o direito e veto com relação aos incs. I, alínea $c$, e II, alínea $a$, do art. 35, que previam ser da competência da Assembleia-geral de Credores a substituição do administrador judicial e a eleição de seu substituto, na recuperação judicial e na falência, respectivamente." $278-279$

\footnotetext{
${ }^{273}$ Art. 19, LRE.

274 Art. 22, inc. I, al. "g”, LRE.

275 Poderão também requerer ao juiz a convocação de assembleia-geral os credores que representem no mínimo $25 \%$ (vinte e cinco por cento) do valor total dos créditos de uma determinada classe, nos termos do art. $36, \S 2^{\circ}$, LRE.

${ }^{276}$ Art. 37, caput, LRE.

277 Art. $37, \S 1^{\circ}$, LRE.

${ }^{278}$ FRANÇA, Erasmo Valladão Azevedo e Novaes. In: SOUZA JUNIOR, Francisco Satiro de, e PITOMBO, Antônio Sérgio de A. Moraes. (coord.). Comentários à Lei de Recuperação de Empresas e Falência. Lei 11.101/2005. - Artigo por Artigo. $2^{\mathrm{a}}$ ed. São Paulo: Revista dos Tribunais, 2.007, p. 205.

${ }^{279}$ Em sentido contrário, entendendo ser possível a destituição do administrador judicial em assembleia de credores, apenas competindo ao juiz a nomeação de outra pessoa para exercer o cargo, cf. CARVALHOSA,
} 
A cautela do administrador judicial deve iniciar-se antes mesmo da instalação e funcionamento da assembleia ${ }^{280}$. Como ressalta Modesto Carvalhosa, nos caso da assembleia-geral de credores, ele deverá examinar os documentos de legitimação dos credores; verificar os poderes de representação ${ }^{281}$, formar a lista de presença ${ }^{282}$ e solicitar a aposição da assinatura dos credores, além de resolver eventuais dúvidas que surgirem ${ }^{283}$. Ato contínuo, deverá declarar a instalação da assembleia ${ }^{284}$, com a composição da mesa, que contará com ele como presidente (exceto na hipótese de assembleia que vise à alteração do administrador judicial ou em outras em que haja incompatibilidade deste), e designar um secretário dentre qualquer um dos credores presentes ${ }^{285}$. Deverá, então, verificar a existência ou não de quorum legal para o prosseguimento ${ }^{286} \mathrm{e}$, em caso positivo, declarar a assembleia-geral regularmente instalada.

O administrador judicial determinará, então, que o secretário faça a leitura da ordem do dia, e colocará em discussão as matérias constantes do edital de convocação. Com efeito, é com a instalação da assembleia que começamos a ver certo poder

Modesto. In: CÔRREA-LIMA, Osmar Brina e LIMA, Sérgio Mourão Corrêa (coord.). Comentários à Nova lei de Falência e Recuperação de Empresas: Lei $n^{o}$ 11.101, de 09 de fevereiro de 2005. $1^{\mathrm{a}}$ ed. Rio de Janeiro: Forense, 2.009, p. 270.

${ }^{280}$ Alfredo Luiz Kugelmas e Gustavo Henrique Sader de Arruda Pinto ressaltam a complexidade que a organização para a realização de uma assembleia-geral de credores, principalmente nas recuperações judiciais de grande porte, pode requerer: "Para que o leitor tenha uma ideia do que significa preparar uma assembleiageral de credores, informa o primeiro autor dessas linhas que para a primeira assembleia que presidiu na recuperação judicial de sociedade que tinha mais de 13.000 (treze mil credores sic) credores arrolados, despendida foi por ele uma equipe composta por profissionais da área jurídica e contábil que contaram com o apoio de especialistas em informática, 4 (quatro) dias para preparar a lista dos credores que se fariam presentes na falência, separando pelas classes mencionadas no artigo 41 da Lei 11.101/05, com a apuração do percentual do crédito." KUGELMAS, Alfredo Luiz e ARRUDA PINTO, Gustavo Henrique Sader de. Administrador judicial na recuperação judicial: Aspectos Práticos. In: DELUCCA, Newton de, e DOMINGUES, Alessandra de Azevedo (coord.). Direito Recuperacional. Aspectos teóricos e práticos. $1^{\mathrm{a}} \mathrm{ed}$. São Paulo: Quartier Latin, 2.009, p. 207-208.

281 Os credores participar através de mandatários ou de seus representantes legais, desde que entreguem ao administrador judicial documento comprobatório de seus poderes ou indiquem as folhas dos autos do processo em que se encontre tal documento, até 24 (vinte e quatro) horas antes da data prevista no aviso de convocação (art. 37, § 4, LRE). Os sindicatos de trabalhadores poderão representar seus associados que sejam titulares de créditos do devedor desde que apresentem a relação de associados que pretendem representar em até 10 (dez) dias antes da data da assembleia (art. 37, § $6^{\circ}$, LRE).

${ }^{282}$ Para facilitar o computo do quorum, aconselha-se que ao lado da assinatura de cada credor, conste o valor de seu crédito. FRANÇA, Erasmo Valladão Azevedo e Novaes. In: SOUZA JUNIOR, Francisco Satiro de, e PITOMBO, Antônio Sérgio de A. Moraes. (coord.). Comentários à Lei de Recuperação de Empresas e Falência. Lei 11.101/2005. - Artigo por Artigo. $2^{\text {a }}$ ed. São Paulo: Revista dos Tribunais, 2007, p. 203.

283 CARVALHOSA, MODESTO. In: CÔRREA-LIMA, Osmar Brina e LIMA, Sérgio Mourão Corrêa (coord.). Comentários à Nova lei de Falência e Recuperação de Empresas: Lei $n^{o} 11.101$, de 09 de fevereiro de 2005. $1^{\mathrm{a}}$ ed. Rio de Janeiro: Forense, 2.009, p. 269.

${ }^{284}$ Art. 37, § $3^{\circ}$, LRE.

${ }^{285}$ Art. 37, "caput", LRE.

${ }^{286}$ A assembleia será instalada com a presença dos credores detentores de mais da metade dos créditos de cada classe, computados pelo valor, e, em qualquer número em segunda convocação (art. 37, § $2^{\circ}$, LRE). 
discricionário do administrador judicial, já que ele poderá, por exemplo, alterar a ordem das matérias a serem debatidas contanto que tal inversão não resulte prejuízo a nenhum dos participantes; ou determinar a exclusão do recinto daqueles que pratiquem "atos que puderem ser caracterizados como crimes ou contravenções, ou atentarem contra o decoro, inclusive por motivos de embriaguez, ou manifesta insanidade mental, mas não por excessos verbais ou pela apresentação de protestos veementes" 287 . Dizemos "certo poder discricionário" porque, ainda que existente, não é ilimitado. Assim, como ressalta Erasmo Valladão Azevedo e Novaes França, o administrador judicial não poderá deixar de computar "os votos dos credores em razão de seu conteúdo - sujeito, exclusivamente, ao controle judicial",288.

Findas as discussões, o administrador judicial submeterá as matérias à votação e proclamará o resultado.

Determinará, em seguida, que o secretário lavre a ata, que deverá necessariamente conter o nome dos presentes e as assinaturas do presidente, do devedor e de dois membros de cada uma das classes votantes.

O administrador judicial declarará o encerramento da assembleia-geral de credores e deverá entregar o ato lavrado ao juiz, juntamente com a lista de presença, no prazo de 48 (quarenta e oito) horas ${ }^{289}$.

\subsubsection{Contratação de auxiliares.}

Apesar de não haver previsão expressa neste sentido, como havia no artigo 61 da $\mathrm{LF}^{290}$, a função do administrador judicial é pessoal e indelegável ${ }^{291}$. Trata-se de cargo de

\footnotetext{
${ }^{287}$ FRANÇA, Erasmo Valladão Azevedo e Novaes. In: SOUZA JUNIOR, Francisco Satiro de, e PITOMBO, Antônio Sérgio de A. Moraes. (coord.). Comentários à Lei de Recuperação de Empresas e Falência. Lei 11.101/2005. - Artigo por Artigo. $2^{\mathrm{a}}$ ed. São Paulo: Revista dos Tribunais, 2.007, p. 203.

${ }^{288}$ FRANÇA, Erasmo Valladão Azevedo e Novaes. In: SOUZA JUNIOR, Francisco Satiro de, e PITOMBO, Antônio Sérgio de A. Moraes. (coord.). Idem, p. 204.

${ }^{289}$ Art. $37, \S 7^{\circ}$, LRE.

${ }^{290}$ Art. 61, "caput", LF: "A função do síndico é indelegável, podendo ele, entretanto, constituir advogado quando exigida a intervenção deste em juízo."

${ }^{291}$ PENTEADO, Mauro Rodrigues. In: CÔRREA-LIMA, Osmar Brina e LIMA, Sérgio Mourão Corrêa (coord.). Comentários à Nova lei de Falência e Recuperação de Empresas: Lei $n^{\circ} 11.101$, de 09 de fevereiro de 2005. $1^{\mathrm{a}}$ ed. Rio de Janeiro: Forense, 2.009, p.180.
} 
confiança absoluta do magistrado, o que impede o seu exercício por outra pessoa. Aliás, ainda que o administrador judicial seja pessoa jurídica, deverá, no ato da investidura no cargo, constar do termo de compromisso o nome do profissional responsável pela condução do processo, o qual não poderá ser substituído sem autorização judicial ${ }^{292}$.

Tal fato não obsta, no entanto, que, em determinadas hipóteses, o administrador judicial conte com assessoria especializada e contrate auxiliares para o desempenho de suas funções ${ }^{293}$. Como exemplos clássicos podemos citar os contadores, economistas, peritos, e advogados ${ }^{294}$, que auxiliam os administradores judiciais.

Em todas as hipóteses, o administrador judicial deverá levar ao juízo da recuperação judicial ou da falência a proposta de contrato de prestação de serviços apresentada por essas empresas ou auxiliares, a fim de obter a necessária autorização judicial para fazer tal contratação. Aqui merece destaque a posição de Haroldo Malheiros Duclerc Verçosa no sentido de que seria possível dispensar tal formalidade, permitindo-se a contratação direta dos auxiliares pelo administrador judicial, e a sua responsabilização direta no caso de abuso de direito ${ }^{295}$.

A remuneração dos auxiliares será fixada pelo magistrado, de acordo com os mesmos critérios legais utilizados para a estipulação da remuneração do administrador judicial, observando-se, assim, tanto o grau de complexidade do trabalho e os valores praticados no mercado como também a capacidade de pagamento da empresa em recuperação judicial ou pela massa falida ${ }^{296}$.

Os auxiliares não se confundem com os prepostos do administrador judicial. Admite-se o trabalho dos prepostos, em casos específicos com o escopo de garantir maior

\footnotetext{
${ }^{292}$ Art. $21, \S$ único, LRE.

293 Art. 22, inc. I, al. "h", LRE.

${ }^{294}$ Entenda-se aqui advogados contratados para representar a massa falida. Advogados que representem ou defendam os interesses do administrador judicial, devem, obviamente ser contratados diretamente pelo próprio, o qual também deverá arcar pessoalmente com seus honorários. PENTEADO, Mauro Rodrigues. In: CÔRREA-LIMA, Osmar Brina e LIMA, Sérgio Mourão Corrêa (coord.). Op cit., p.180. FAZZIO JÚNIOR, Waldo. Lei de Falência e Recuperação de Empresas, $4^{\text {a }}$ ed., São Paulo: Atlas, 2.008, p. 330.

${ }^{295}$ VERÇOSA, Haroldo Malheiros Duclerc. In: SOUZA JUNIOR, Francisco Satiro de, e PITOMBO, Antônio Sérgio de A. Moraes. (coord.). Comentários à Lei de Recuperação de Empresas e Falência. Lei 11.101/2005. - Artigo por Artigo. $2^{\mathrm{a}}$ ed. São Paulo: Revista dos Tribunais, 2.007, p. 170.

${ }^{296}$ Art. 22, § 1" , c/c art. 24, "caput", LRE.
} 
celeridade nos processos de recuperação judicial ou falência ${ }^{297}$. Estes também devem ser previamente indicados e aceitos pelo juízo concursal. Todavia, os prepostos agem em nome do administrador judicial e são remunerados diretamente por este. $\mathrm{O}$ administrador judicial é responsável, de forma objetiva, pela atuação de seus prepostos, nos termos do artigo 932 e 933 do Código Civil, sendo o preposto apenas responsabilizado quando se exceder nas atribuições que lhe foram conferidas, conforme prescrevem os artigos 1.169 a 1.171, também do CC.

O mesmo não ocorre com os auxiliares acima citados, descritos na aliena "h" do inciso I do artigo 22 da LRE. Como acima exposto, sua remuneração competirá à empresa em recuperação ou à massa falida e a responsabilidade por seus atos não recairá na pessoa do administrador judicial, exceto se este também agir (ou deixar de agir, quando na verdade assim deveria ter feito) pessoalmente, com culpa ou dolo.

\subsubsection{Manifestação nos casos previstos em lei e sempre que necessário.}

O administrador judicial deverá se manifestar no processo nas hipóteses previstas na LRE e também sempre que necessário. Com efeito, a pronta manifestação do administrador judicial é condição "sine qua non" para uma célere e eficaz recuperação judicial ou falência.

Outrossim, é dever do administrador judicial levar à apreciação do magistrado toda e qualquer suposta fraude que possa vir a ocorrer durante o decorrer do processo da recuperação judicial e também da falência. Assim, deverá relatar os fatos presenciados de forma minuciosa, a fim de amparar o juiz e o Ministério Público na apuração de eventual abuso de direito de voto, manipulação de votos nas assembleias por meio de cessões de crédito ou outorga de procurações; desvio de bens; desvio de faturamento e clientela para outras empresas; confusão patrimonial, dentre outros.

\footnotetext{
${ }^{297}$ Tomemos como exemplo, a hipótese de o administrador judicial dever comparecer pessoalmente em um ato essencial do processo (ex: leilão judicial dos bens da massa falida) e necessitar também que estar presente em outra comarca para retirada de um oficio ou realização de uma audiência trabalhista da mesma falência.
} 


\subsubsection{Deveres e atribuições legais exclusivos da recuperação judicial.}

As principais atividades do administrador judicial que são exclusivas da recuperação judicial podem ser agrupadas em 2 (duas) frentes: i) fiscalização das condutas do devedor e do cumprimento do seu plano de recuperação, com a apresentação dos devidos relatórios, em ambos os casos; e ii) gestão da empresa, em caráter excepcional.

\subsubsection{Fiscalização das atividades do devedor, com a apresentação de relatórios mensais.}

Uma das principais atividades do administrador judicial na recuperação é a fiscalização das atividades do devedor ${ }^{298}$. Todavia, os limites de tal atividade exercida pelo administrador judicial geram polêmica na doutrina e na jurisprudência, como se passa a expor.

O único ponto inconteste, seja na doutrina, seja na jurisprudência, é que o administrador não administra a empresa em crise. Foi infeliz o legislador ao alterar a anterior denominação de comissário e sindico para administrador judicial. De uma leitura rápida e despreparada, é possível entender que com o deferimento do processamento da recuperação judicial a administração da empresa passará das mãos dos administradores ou diretores nomeados para o administrador judicial. Ledo engano. A LRE é clara no sentido de que durante o processo de recuperação judicial, a regra é a condução da atividade empresarial pelo devedor ou por seus administradores, na forma do estatuto ou contrato social $^{299}$.

A administração permanecerá da forma que está e não haverá desapossamento dos bens, como ocorre na falência; não haverá ingerência nos negócios da empresa ou em substituição de seus administradores. O afastamento do devedor ou de seus diretores da administração ocorre apenas em caráter excepcional e "pro tempore", nas situações

\footnotetext{
${ }^{298}$ Art. 22, inc. II, al. “a”, c/c art. 64, “caput”, LRE.
}

${ }^{299}$ Art. 64, LRE. 
descritas no artigo 64 da LRE, ou caso o plano de recuperação judicial assim o preveja, contemplando a hipótese prevista no inciso IV do artigo 50 da $\mathrm{LRE}^{300}$.

Caberá, portanto, ao administrador judicial, a fiscalização das atividades exercidas pela empresa, juntamente com o comitê de credores, se houver, além da verificação do cumprimento do plano, para, se for o caso, informar o juízo sobre o que tiver constatado. Com efeito, o administrador judicial tem o dever de informar todo e qualquer fato que seja relevante para o processo, em especial se o devedor descumprir a lei ou o plano, prejudicar credores, ou violar deveres, sob pena de responder por negligência, nos termos do artigo 32 da LRE $^{301}$.

Mas qual seriam os limites de tal fiscalização?

Paulo Fernando Campos Salles de Toledo ensina que o administrador judicial deverá, para a sua eficaz atuação, "ter acesso pleno aos estabelecimentos da devedora e a seus livros e documentos, mas sempre com o cuidado de não atrapalhar o fluxo normal de suas atividades negociais". ${ }^{302}$ Também neste sentido David Giansante, que entende que a "fiscalização deve ser exercida com parcimônia, sob pena de constrangimento ilegal"; administrador judicial pode comparecer na empresa e ter acesso a seus livros e documentos "quando bem lhe aprouver, desde que exista alguma razão para tanto",303.

Alfredo Luiz Kugelmas e Gustavo Henrique Sauer de Arruda Pinto vão mais longe. Embora deixem claro que o administrador judicial não pratica atos de gestão do devedor em recuperação judicial e, via de consequência, não decide sobre os negócios da empresa, entendem ser possível que o administrador judicial e seus assessores

\footnotetext{
${ }^{300}$ Note-se que a redação original do Projeto de Lei n. $4.376 / 93$ enviado ao Congresso Nacional previa o afastamento automático do administrador da empresa no momento do deferimento da recuperação e a nomeação do administrador judicial, com exceção para as hipóteses do devedor individual em recuperação judicial ou das empresas de pequeno e médio porte com receita que não comportasse o pagamento do administrador judicial.

${ }^{301}$ FONSECA, Humberto Lucena Pereira. In: CÔRREA-LIMA, Osmar Brina e LIMA, Sérgio Mourão Corrêa (coord.). Comentários à Nova lei de Falência e Recuperação de Empresas: Lei no 11.101, de 09 de fevereiro de 2005. $1^{\mathrm{a}}$ ed. Rio de Janeiro: Forense, 2.009, p. 431.

${ }^{302}$ TOLEDO, Paulo Fernando Campos Salles de. In: TOLEDO, Paulo Fernando Campos Salles de, e ABRÃO, Carlos Henrique (coord.). Comentários à Lei de Recuperação de Empresas e Falência. 4a. ed. São Paulo: Saraiva, 2.010, p. 109.

${ }^{303}$ GIANSANTE, Gilberto. Um ensaio prático sobre a recuperação judicial especial: a visão do advogado e do administrador judicial. In: DELUCCA, Newton, e DOMINGUES, Alessandra de Azevedo (coord.). Direito Recuperacional. Aspectos teóricos e práticos. 1ª ed. São Paulo: Quartier Latin, 2.012, p. 312.
} 
especializados em estratégia, reestruturação e recuperação de empresas, orientem a sociedade em recuperação para que ela possa superar as suas dificuldades e se soerguer, "buscando novos mercados, apresentando-lhe sugestões relativas às estratégias de marketing e vendas, criação de novos produtos, dentre outras (...)"304. Ressalvam, porém, que por ser um procedimento de alto custo monetário, tal prática de assessoramento apenas poderia ser viável para as empresas de grande porte.

Já Julio Kahan Mandel, em posição oposta, ressalta que a atividade de fiscalização pelo administrador "não lhe dá poderes para interferir nos atos administrativos sem o devido processo legal e autorização judicial, nem ao menos ter livre acesso à sede da empresa e reuniões internas ou externas dos administradores com acionistas, fornecedores, clientes e até credores." ${ }^{\text {,305 }}$ Para ele, a físcalização, exceto se houver disposição em contrário, deverá ocorrer por meio da análise dos balancetes mensais e/ou relatórios apresentados pelo devedor. Qualquer visita deve ser previamente solicitada à empresa ou efetuada apenas com autorização judicial.

Entendemos ser mais coerente com o espírito da LRE, a posição de Paulo Fernando Campos Salles de Toledo e David Giansante, sendo, assim, possível o ingresso do administrador judicial nos estabelecimentos do devedor para a verificação da situação fática na qual se encontra e a análise de seus documentos. A necessidade de autorização judicial para tanto iria contra o escopo da lei de dar celeridade ao processo de recuperação judicial. Apenas para a hipótese de a devedora ter negado o acesso do administrador judicial às suas dependências, é imprescindível a competente ordem judicial.

A fiscalização da empresa em recuperação não deve ser feita apenas pela leitura dos balancetes mensais para a apresentação do relatório mensal de atividades. A elaboração do relatório mensal atividades do devedor é um dever imposto ao administrador judicial, sob pena de destituição ${ }^{306}$. Ele não deve conter informações que simplesmente reflitam o dia a dia da empresa, mas sim aquelas que sejam pertinentes à recuperação

\footnotetext{
${ }^{304}$ KUGELMAS, Alfredo Luiz e ARRUDA PINTO, Gustavo Henrique Sauer de. Administrador judicial na recuperação judicial: Aspectos Práticos. In: DELUCCA, Newton de, e DOMINGUES, Alessandra de Azevedo (coord.). Direito Recuperacional. Aspectos teóricos e práticos. 1a ed. São Paulo: Quartier Latin, 2.009, p. 203-204.

${ }^{305}$ MANDEL, Julio Kahan. Nova Lei de Falências e Recuperação de Empresas anotada. Lei n. 11.101, de 9 de fevereiro de 2005. $1^{\mathrm{a}}$ ed. São Paulo: Saraiva, 2.005, p. 51-52.

${ }^{306}$ Art. 22, inc. II, al. $c$ c/c art 23, LRE.
} 
judicial, como por exemplo, cumprimento ou não de obrigações constantes do plano ou contraídas após o ajuizamento da recuperação, venda de ativo relevante, remoção de bens, dentre outros, e o que, necessariamente, demandará de visitas nas dependências do devedor em recuperação judicial ${ }^{307}$.

A emissão de relatório mensal não é muito bem vista por parte da doutrina, que, como Haroldo Malheiros Duclerc Verçosa ${ }^{308}$ e Ecio Perin Júnior ${ }^{309}$ entendem que tal obrigação poderá tornar o processo excessivamente moroso e desviar a atenção do administrador judicial de outras atividades de maior importância.

Os relatórios mensais a serem apresentados pelo administrador judicial devem conter todas as informações pertinentes à "saúde" de empresa em recuperação judicial. O administrador judicial, além da constatação de cumprimento ou não do plano, deverá ser diligente, por exemplo, na verificação de eventuais irregularidades e/ou ilegalidades praticadas pelo devedor. Tais procedimentos, evidentemente, não poderão ser feitos com a exatidão necessária da leitura de um simples balancete, dependendo de uma atuação eficaz do administrador judicial.

Por outro lado, nunca é demais lembrar que a fiscalização a ser exercida pelo administrador judicial em hipótese alguma pode se transformar em ingerência e/ou intervenção, exceto nos casos de gestão acima citados. Justamente por isso, entendemos que a orientação sobre os rumos a serem tomados pela devedora, conforme sugerem Alfredo Luiz Kugelmas e Gustavo Henrique Sauer de Arruda Pinto, não se enquadra nas competências desse órgão auxiliar da Justiça. Como os próprios autores afirmam, para as pequenas e médias empresas o custo da recuperação judicial (incluindo-se, aí, os

\footnotetext{
${ }^{307}$ Neste sentido, vide sentença de decretação de falência de Natan Jóias Ltda., proferida pela $7^{\text {a }}$ Vara Empresarial do Foro da Comarca do Rio de Janeiro, processo 0209874-03.2012.8.19.0001, em 30/04/2013, no qual resta demonstrado de maneira clara e inequívoca a importância de uma atuação efetiva do administrador judicial, na verificação "in locu" dos atos praticados pela empresa. Neste caso, o administrador judicial pode verificar a falta de um gerenciamento efetivo, o fechamento de diversos pontos comerciais, a falta de pagamento de funcionários, além de outros dados omitidos nas informações prestadas pela empresa e em seus demonstrativos contábeis.

${ }^{308}$ VERÇOSA, Haroldo Malheiros Duclerc. In: SOUZA JUNIOR, Francisco Satiro de, e PITOMBO, Antônio Sérgio de A. Moraes. (coord.). Comentários à Lei de Recuperação de Empresas e Falência. Lei 11.101/2005. - Artigo por Artigo. $2^{\mathrm{a}}$ ed. São Paulo: Revista dos Tribunais, 2.007, p. 171.

${ }^{309}$ PERIN JÚNIOR, Ecio. O administrador judicial e o comitê de credores. In: PAIVA, Luiz Fernando Valente de (coord.). Direito Falimentar e a nova lei de falências e recuperação de empresas. São Paulo: Quartier Latin, 2.005, p. 184.
} 
honorários de seus advogados e do administrador judicial, os custos de editais, dentre outros) por si só, já é deveras elevado e, por muitas vezes, acaba por inviabilizar a recuperação como um todo. Ademais, o projeto de reestruturação da sociedade é ônus da própria empresa que pretende socorrer-se da recuperação judicial (e outro não poderia ser o entendimento já que a LRE confere única e exclusivamente ao devedor a possibilidade de requerer sua recuperação judicial, nos termos dos artigos 48 e 95 da LRE). Caso assim fosse, não seria necessária a apresentação de plano de recuperação com a discriminação pormenorizada dos meios de recuperação a serem empregados, a demonstração de sua viabilidade econômica e a apresentação de laudo econômico-financeiro, conforme prescreve o artigo 53 da LRE.

\subsubsection{Fiscalização do cumprimento do plano, com requerimento de falência no caso de descumprimento de obrigação ali assumida.}

A fiscalização feita pelo administrador judicial (juntamente com o comitê de credores, se houver) permanecerá mesmo após a aprovação do plano de recuperação pela assembleia-geral de credores, até o encerramento da recuperação judicial ${ }^{310}$.

Note-se que a função do administrador judicial aqui discutida é a fiscalização do cumprimento do plano previamente aprovado pelos credores. Não cabe ao administrador judicial manifestar-se sobre o plano ${ }^{311}{ }_{-}^{312}$ antes ou durante a assembleia, salvo se verificar alguma ilegalidade ou fraude, fato este que deverá ser comunicado ao juízo concursal.

Caso a empresa em recuperação judicial descumpra obrigação assumida no plano, a LRE confere ao administrador judicial legitimidade processual ativa para requerer

\footnotetext{
${ }^{310}$ Art. 22, inc. II, al. "a" e "b" c/c art. 61, da LRE.

311 COELHO, Fábio Ulhoa. Comentários à Lei de Falências e de Recuperação de Empresas. $8^{\mathrm{a}}$ ed. São Paulo: Saraiva, 2.011, p. 242.

312 TJSP, AI n. 574.851-4/0-00, Rel. Des. José Roberto Lino Machado, Câmara Especial de Falências e Recuperações Judiciais de Direito Privado, j. 29/10/08, v.u.
} 
a sua falência ${ }^{313}$. Na hipótese de acolhimento de sua petição, a recuperação judicial será convolada em falência, conforme dispõe o artigo 73, inciso IV, da LRE.

A LRE é clara no sentido de ser uma obrigação do administrador judicial, não competindo a ele transigir com o devedor sobre o inadimplemento. Desta forma, o administrador judicial apenas estará isento de requerer a falência caso haja autorização em sentido contrario em eventual nova assembleia de credores.

No prazo de quinze dias contados da publicação da sentença, deverá o administrador judicial entregar ao juízo o seu relatório final, versando sobre a execução do plano de recuperação judicial até então ${ }^{314}$. Como ressalta Eduardo Secchi Munhoz, este relatório é de "pouca valia”, já que a sentença de encerramento da recuperação judicial já estará decretada quando da sua apresentação ${ }^{315}$.

\subsubsection{Gestão do devedor.}

Como exposto no tópico 3.4.2.1 supra, na recuperação judicial a administração da empresa caberá ao devedor ou a seus administradores ou diretores (de forma semelhante ao "debtor-in-possession" do "Bankruptcy Code" norte-americano ${ }^{316}$ ).

Todavia, na hipótese de configuração de alguma das exceções previstas nos incisos I a IV do artigo 64 da LRE, o devedor será destituído da administração e enquanto a assembleia-geral de credores não deliberar sobre a escolha do nome do gestor judicial, esta função será exercida pelo administrador judicial ${ }^{317}$.

Inicialmente cumpre esclarecer o que deve ser entendido por "devedor" nos termos da LRE. Como explica Eduardo Secchi Munhoz, o artigo 64 da LRE reflete ainda a grande confusão existente tanto na lei, como na doutrina e na jurisprudência pátrias entre

\footnotetext{
${ }^{313}$ Art. 22, inc. II, al. "b”, LRE.

${ }^{314}$ Art. 63, inc. III, LRE.

${ }^{315}$ MUNHOZ, Eduardo Secchi. In: SOUZA JUNIOR, Francisco Satiro de, e PITOMBO, Antônio Sérgio de A. Moraes. (coord.). Comentários à Lei de Recuperação de Empresas e Falência. Lei 11.101/2005. - Artigo por Artigo. $2^{\mathrm{a}}$ ed. São Paulo: Revista dos Tribunais, 2.007, p. 300.

${ }^{316} 11$ U.S.C. $\$ 1107$.

${ }^{317}$ Art. 65, LRE.
} 
as figuras do "empresário" e da "empresa" e da "sociedade" e dos "sócios e seus administradores", em face da elevada concentração de poder empresarial que impera no Brasil. Além disso, muitas das condutas relacionadas no artigo 64, como, por exemplo, os crimes previstos no inciso I, apenas podem ser praticadas pelos sócios controladores ou administradores, mas nunca pela própria sociedade. Por tais razões, defende posição com a qual concordamos, no sentido de que em se tratando de sociedade de responsabilidade limitada, deve-se interpretar os artigo 64 e 65 da LRE lendo-se "sócio controlador" ao invés de "devedor" ${ }^{318}{ }^{319}$. Caso contrário, estar-se-ía afastando indevidamente os sócios nãos controladores, que têm legítimo interesse no processo de recuperação judicial.

O rol previsto no artigo 64 é taxativo ${ }^{320}$. Apenas pode ser destituído o “devedor" que: i) tiver sido condenado em sentença penal transitada em julgado, por crime cometido em recuperação judicial ou falências anteriores ou por crime contra o patrimônio, a economia popular ou a ordem econômica previstos na legislação; ii) tiver indícios veementes de ter cometido crime previsto na LRE (não sendo necessário, pois, o transito em julgado); iii) tiver agido com dolo, simulação ou fraude contra os interesses dos credores (artigo 145, 158 e 167, todos do CC, respectivamente); iv) tiver praticado condutas que caracterizam má administração ou confusão patrimonial ${ }^{321}$; v) deixar de prestar as informações solicitadas pelo administrador judicial ou pelo comitê de credores; vi) tiver seu afastamento previsto no plano de recuperação judicial.

\footnotetext{
${ }^{318}$ MUNHOZ, Eduardo Secchi. In: SOUZA JUNIOR, Francisco Satiro de, e PITOMBO, Antônio Sérgio de A. Moraes. (coord.). Comentários à Lei de Recuperação de Empresas e Falência. Lei 11.101/2005. - Artigo por Artigo. $2^{\text {a }}$ ed. São Paulo: Revista dos Tribunais, 2.007, p. 307-315.

${ }^{319}$ Em sentido contrário, entendendo que por falta de previsão legal, os impedimentos do art. 64 não são aplicáveis aos controladores, cf. FONSECA, Humberto Lucena Pereira. In: CÔRREA-LIMA, Osmar Brina e LIMA, Sérgio Mourão Corrêa (coord.). Comentários à Nova lei de Falência e Recuperação de Empresas: Lei $n^{o}$ 11.101, de 09 de fevereiro de 2005. $1^{\text {a }}$ ed. Rio de Janeiro: Forense. 2.009, p. 423.

${ }^{320}$ Eduardo Secchi Munhoz tece severas criticas ao tratamento restritivo das hipóteses para afastamento. Segundo ele, a LRE foi “tímida", o que poderá "salvar o empresário, mas punir a empresa”. Deveria ter permitido o afastamento, por exemplo, "pela vontade de parcela significativa dos credores, ou ainda por atos praticados em sentido contrario aos objetivos da recuperação”. MUNHOZ, Eduardo Secchi. In: SOUZA JUNIOR, Francisco Satiro de, e PITOMBO, Antônio Sérgio de A. Moraes. (coord.). Comentários à Lei de Recuperação de Empresas e Falência. Lei 11.101/2005. - Artigo por Artigo. $2^{\mathrm{a}}$ ed. São Paulo: Revista dos Tribunais, 2.007, p. 315 .

${ }^{321} \mathrm{O}$ rol dessas condutas também é taxativo, cf. art. 64, inc. IV, al. "a" a "d", da LRE: efetuar gastos pessoais manifestamente excessivos; fizer despesas injustificáveis por sua natureza ou vulto em relação à natureza ou gênero do negócio; descapitalizar de forma injustificada a empresa ou realizar operações prejudicais ao seu funcionamento; e simular ou omitir créditos na relação de credores apresentadas com a petição inicial.
} 
Na ocorrência de qualquer uma das hipóteses acima descritas, o juiz destituirá o "devedor ou seus administradores", que deverão ser substituídos "na forma prevista nos autos constitutivos do devedor ou do plano de recuperação judicial”322.

Enquanto a assembleia-geral de credores não deliberar sobre a escolha do gestor judicial, ou nas hipóteses de o gestor indicado se recusar ou estiver impedido de assumir o encargo, caberá ao administrador judicial exercer as suas funções ${ }^{323}$.

Note-se que o gestor judicial não representa nenhuma classe de credores nem tampouco a sociedade em recuperação ou seus sócios. Ele exerce a administração de forma ampla, devendo "proteger todos os interesses em jogo, buscando a consecução do interesse público que preside a recuperação da empresa" ${ }^{324}$. Em outras palavras, durante o período que o administrador judicial atuar no lugar do gestor assumirá a posição de controle e deverá exercer a gestão da sociedade seguindo as mesmas observações e objetivos constantes do artigo 47 da $\operatorname{LRE}^{325}$.

Ainda que seja por um período breve e por motivos excepcionais, a designação do administrador judicial para a gestão da empresa parece não ser a melhor solução para esta hipótese. Em primeiro lugar, nem sempre o administrador judicial será o melhor gestor, ainda que temporariamente, para o caso concreto: seria necessário questionar se o administrador judicial teria a experiência e conhecimento necessários para administrar a empresa de fato, com todas as suas peculiaridades, ainda que por período exíguo. Ademais, tal atribuição acaba por gerar um verdadeiro conflito de competência para não se dizer patente incompatibilidade, haja vista que a função primordial do administrador judicial na reorganização da devedora em recuperação é de fiscalização justamente das atividades empresariais e o cumprimento do plano. Se o fiscal do cumprimento da lei, das atividades do devedor e do plano se torna gestor da empresa, quem fiscalizará sua atuação? A

\footnotetext{
${ }^{322}$ Art. 64, §. único, LRE.

${ }^{323}$ Art. 65 , par. $1^{\circ}$ e $2^{\circ}$, LRE.

${ }^{324}$ MUNHOZ, Eduardo Secchi. In: SOUZA JUNIOR, Francisco Satiro de, e PITOMBO, Antônio Sérgio de A. Moraes. (coord.). Comentários à Lei de Recuperação de Empresas e Falência. Lei 11.101/2005. - Artigo por Artigo. $2^{\mathrm{a}}$ ed. São Paulo: Revista dos Tribunais, 2.007, p. 315.

${ }^{325}$ Fábio Ulhoa Coelho, em posição discordante, entende que a representação da sociedade "nos atos relativos à tramitação do processo de recuperação judicial continuará sendo representada nos termos de seus atos constitutivos" .COELHO, Fábio Ulhoa. Comentários à Lei de Falências e de Recuperação de Empresas. $8^{\text {a }}$ ed. São Paulo: Saraiva, 2.011, p. 259. Também neste sentido, MANGE, Renato. O administrador judicial, o gestor judicial e o comitê de credores na Lei n. 11.101/05. In: SANTOS, Paulo Penalva (coord.). A Nova Lei de Falências e Recuperação de Empresas. Lei 11.101/05. $1^{\mathrm{a}}$ ed. Rio de Janeiro: Forense, 2007, p. 71.
} 
fiscalização será feita somente pelo comitê de credores, que geralmente inexiste nas recuperações judiciais, e pelo juiz, que em face de sua própria atuação não poderá acompanhar "in loco" a atividade do gestor-administrador judicial. Por tais motivos, esta situação, ainda que excepcional deve ser resolvida com a maior brevidade a fim de "evitar prejuízos aos procedimentos e à eficiência da recuperação"326.

Por fim, note-se que por exercer duas funções distintas (fiscalização e gestão), o administrador judicial fará jus a uma dúplice remuneração.

\subsubsection{Prestação de contas.}

Na recuperação judicial, a prestação das contas do administrador judicial não é obrigatória $^{327}$, exceto na hipótese de assumir a função de gestor judicial ou ter arcado diretamente com custos pelos quais deverá ser reembolsado. Ele somente está obrigado a apresentar o relatório mensal das atividades do devedor (conforme tópico 3.4.2.1 supra) e o relatório sobre a execução do plano de recuperação (vide tópico 3.4.2.2 supra).

\subsubsection{Deveres e atribuições legais exclusivos da falência.}

Ao contrário do que ocorre na recuperação judicial, na falência o administrador judicial assume a postura de verdadeiro administrador e representante da massa falida - em juízo ou fora dele, sendo o responsável pela arrecadação, avaliação, guarda e venda dos ativos, para posterior pagamento aos credores, como se verá a seguir.

\footnotetext{
${ }^{326}$ FONSECA, Humberto Lucena Pereira. In: CÔRREA-LIMA, Osmar Brina e LIMA, Sérgio Mourão Corrêa (coord.). Comentários à Nova lei de Falência e Recuperação de Empresas: Lei $n^{o}$ 11.101, de 09 de fevereiro de 2005. $1^{\mathrm{a}}$ ed. Rio de Janeiro: Forense, 2.009, p. 450.

${ }^{327}$ Cf. Sérgio Campinho, "no processo de recuperação judicial não há, como regra, procedimento de prestação de contas propriamente dito pelo administrador, mas sim a apresentação de relatório mensal das atividades do devedor (artigo 22, inciso II, alínea 'c') e relatório sobre a execução do plano de recuperação, quando de seu encerramento (artigo 22, inciso II, alínea 'd'). Isto porque o seu papel consiste na fiscalização das atividades do devedor e do cumprimento do plano de recuperação judicial (artigo 22, inciso II, aliena 'a')". CAMPINHO, Sérgio. Falência e Recuperação de Empresa: O novo regime da insolvência empresarial. $6^{\mathrm{a}}$ ed. Rio de Janeiro: Renovar, 2.012, 2012, p. 74-75.
} 


\subsubsection{Aviso aos credores sobre o acesso aos livros e documentos do falido.}

Na busca da transparência, compete ao administrador judicial requerer ao juiz a publicação gratuita na imprensa oficial, do aviso do local e da hora em que os credores poderão acessar os livros e documentos do falido, diariamente ${ }^{328}$.

Em obediência ao disposto no "caput" do artigo 191 da LRE, a publicação em tela não deve ser feita somente no órgão oficial, mas também em jornais ou revistas de circulação regional ou nacional e em periódicos que circulem em todo país, desde que a massa falida possa comportar ${ }^{329}$.

\subsubsection{Exame da escrituração do devedor.}

Apesar de não haver dúvidas sobre a necessidade de realização e da contabilidade de acordo com o previsto no artigo 1.179 e seguintes do CC, é comum que na grande maioria das empresas falidas, a escrituração da devedora não esteja completa ou seu estado de conversação não seja o desejável ${ }^{330}$. A falta de livros ou ainda a falta de lançamentos necessários, pode vir a acarretar ao falido a imputação de crime falimentar, conforme previsto no artigo 168 e seguintes da LRE.

Mesmo assim, o exame da escrituração ${ }^{331}$ existente é de suma importância, pois possibilitará ao administrador judicial tomar conhecimento da situação do devedor e das causas da falência e verificar as irregularidades que porventura tenham ocorrido, servindo de suporte para o relatório previsto na alínea “e”, do inciso III, do artigo 22 da LRE ${ }^{332}$.

\footnotetext{
${ }^{328}$ Art. 22, inc. III, al. "a”, LRE.

${ }^{329}$ VERÇOSA, Haroldo Malheiros Duclerc. In: SOUZA JUNIOR, Francisco Satiro de, e PITOMBO, Antônio Sérgio de A. Moraes. (coord.). Comentários à Lei de Recuperação de Empresas e Falência. Lei 11.101/2005. - Artigo por Artigo. $2^{\mathrm{a}}$ ed. São Paulo: Revista dos Tribunais, 2.007, 171.

${ }^{330}$ SANTOS, José Vanderlei Masson dos. Da atuação do perito contador na Nova lei de Falências e Recuperação de Empresas. In: DELUCCA, Newton, e DOMINGUES, Alessandra de Azevedo (coord.). Direito Recuperacional. Aspectos teóricos e práticos. 1ª ed. São Paulo: Quartier Latin, 2.012, p. 351.

${ }^{331}$ Art. 22, inc. III, al. "b", LRE.

${ }^{332}$ TOLEDO, Paulo Fernando Campos Salles de. In: TOLEDO, Paulo Fernando Campos Salles de, e ABRÃO, Carlos Henrique (coord.). Comentários à Lei de Recuperação de Empresas e Falência. $4^{\mathrm{a}}$. ed. São Paulo: Saraiva, 2.010, p. 111.
} 
Em regra, a escrituração é examinada por auxiliares ${ }^{333}$ do administrador judicial (contadores), cujo contrato de prestação de serviços deverá ter sido previamente aprovado pelo juízo falimentar, conforme já exposto no tópico 3.4.1.7 supra. A análise, segundo José Vanderlei Masson dos Santos, inicia-se "do ponto de vista estritamente formal", verificando-se a existência de escrituração durante todo o período de atividades da falida, a existência de registro dos mesmos nos órgãos devidos, a regularidade e legalidade dos lançamentos apostos nos livros, dentre outros. Prossegue com o estudo material, com a verificação dos balancetes e balanços de encerramento dos exercícios mais próximos à decretação da falência, para se apurar eventuais "variações bruscas nos saldos de cada uma das contas" que possam vir a confirmar a ocorrência de alguma anormalidade; o exame de extratos bancários para detectar a existência ou não de operações não lançadas na contabilidade; e a confrontação dos ativos arrecadados com os registrados na contabilidade, por exemplo. Com o término de suas análises, deverá o contador apresentar seu laudo pericial, "apontando se houve ou não irregularidade, discriminado-as e informando onde se encontram as evidencias que o levaram a tais conclusões", e que, como já exposto acima, servirão de base para que o administrador judicial apresente o seu relatório sobre as causas e circunstâncias que conduziram à falência ${ }^{334}$.

\subsubsection{Recebimento da correspondência dirigida ao devedor.}

Para dar mais celeridade ao processo falimentar, o legislador alterou a exigência da lei anterior, no sentido de que a correspondência somente poderia ser aberta na presença do falido ou de alguém que o representasse para tanto ${ }^{335}$.

A possibilidade agora conferida ao administrador judicial de receber e abrir todas as correspondências ${ }^{336}$ chegou a ter sua constitucionalidade questionada pela

\footnotetext{
${ }^{333}$ Mas nada impede que sejam prepostos do administrador judicial.

${ }^{334}$ SANTOS, José Vanderlei Masson dos. Da atuação do perito contador na Nova lei de Falências e Recuperação de Empresas. In: DELUCCA, Newton, e DOMINGUES, Alessandra de Azevedo (coord.). Direito Recuperacional. Aspectos teóricos e práticos. $1^{\mathrm{a}}$ ed. São Paulo: Quartier Latin, 2.012, p. 350-354.

335 “Art. 63, LF: "Cumpre ao síndico, além de outros deveres que a presente lei lhe impõe:

(...)

II - receber a correspondência dirigida ao falido, abri-la em presença deste ou de pessoa por ele designada, fazendo entrega daquela que se não referir a assunto de interesse da massa; (...)"

${ }^{336}$ Art. 22, inc. III, al. “d”, LRE.
} 
doutrina já que o sigilo da correspondência é inviolável por determinação constitucional. Entretanto, o sigilo protegido é estritamente pessoal, não incluindo a correspondência de interesse da empresa. A correspondência endereçada ao devedor não poderia, a princípio, ser aberta por outra pessoa que não por ele mesmo. Ora, o destinatário da correspondência é um empresário ou uma sociedade empresária cuja falência foi decretada. Não mais pode, por isso, administrar seus bens. Desse modo, a correspondência empresarial só pode mesmo ser aberta por quem tenha poderes para cuidar dos interesses nela consignados, e esta pessoa é o administrador judicial, não o falido.

Ademais, a própria LRE, na parte final do inciso ora analisado, preocupou-se em preservar tal garantia insculpida da Constituição Federal ao ressaltar que toda a correspondência que não for assunto de interesse da massa, deverá ser entregue ao devedor, não havendo, assim, que se falar em quebra de sigilo. Conclui-se, portanto, que não está sendo desrespeitada a garantia constitucional ${ }^{337}$.

\subsubsection{Apresentação de relatório sobre as causas e circunstâncias que conduziram à situação de falência.}

$\mathrm{O}$ administrador judicial deve apresentar relatório sobre as causas da falência da empresa, apontando, inclusive, a responsabilidade civil e penal dos envolvidos, no prazo máximo de oitenta dias contados da assinatura do termo de compromisso (na verdade, quarenta dias prorrogáveis por mais quarenta ${ }^{338}$. Nos termos do artigo 186 da LRE: deverá o administrador judicial expor de forma circunstanciada o procedimento do falido, antes e depois da sentença, levando em consideração as causas da quebra, bem como dar "outras informações detalhadas" sobre a conduta do devedor e eventuais outros responsáveis, "por atos que possam constituir crime relacionado com a recuperação judicial ou com a falência, ou outro delito conexo a estes".

\footnotetext{
${ }^{337}$ A doutrina, no entanto, não é uníssona neste sentido. Vera Helena de Mello Franco e Rachel Sztajn criticam a redação dada ao supra referido dispositivo legal: "Ressalte-se que a atual não repetiu a exigência no que andou mal, tendo em vista a possibilidade de abusos, já que não é facultado ao administrador judicial estender-se, por pura curiosidade, sobre o teor das missivas que versem interesses particulares do devedor." FRANCO, Vera Helena de Mello e SZTAJN, Rachel. Falência e Recuperação de Empresa em Crise. $1^{\mathrm{a}}$ ed. Rio de Janeiro. Elsevier, 2.008, p. 64.

${ }^{338}$ Art. 22 , inc. III, al. "e", da LRE.
} 
Com base nesse relatório, o Ministério Público oferecerá, se for o caso, a devida denúncia, conforme determina o parágrafo $1^{\circ}$ do artigo 187 do mesmo diploma legal.

Ocorre que, na grande maioria das vezes, por mais diligentes que o administrador judicial e a sua equipe sejam, o prazo legal concedido é exíguo já que a análise de eventuais fraudes praticadas pelo falido e terceiros geralmente dependem de respostas de ofícios e órgãos públicos e privados, intimação e oitiva de terceiros em diversas comarcas, etc., procedimentos esses que acabam por ultrapassar o prazo de 80 dias. Nestes casos, como ressalta Haroldo Malheiros Duclerc Verçosa, "não terá o juiz como deixar de conceder prazos excepcionais, a seu critério, uma vez demonstrada a necessidade, neste sentido, pelo administrador judicial" 339 .

As críticas a este dispositivo legal não se encerram no prazo concedido e dizem respeito à atribuição conferida ao administrador judicial de apresentar a responsabilidade penal dos envolvidos, com a consequente intimação do Ministério Público, nos termos do parágrafo $4^{\circ}$ do artigo 22. Melhor seria se a LRE tivesse determinado ao administrador judicial a apresentação dos fatos que entendesse serem relevantes, cabendo ao Ministério Público apontar se as condutas praticadas são tipificadas ou não ${ }^{340}$. Neste sentido, ao discorrer sobre a matéria, Paulo Fernando Campos Salles de Toledo ressalta que:

(...) a fragilidade do dispositivo não é apenas topológica. Também seu conteúdo é criticável. Nele se lê que o Ministério Público será intimado quando o relatório em foco "apontar responsabilidade penal de qualquer dos envolvidos". Dois motivos de perplexidade desde logo se evidenciam. O primeiro é o de que se cuida de peça processual relevante, em que se indicam "as causas e circunstâncias que conduziram à situação de falência", justificando-se plenamente, pois, que o Ministério Público seja cientificado de seu teor, que se aponte responsabilidade penal, que não. Em segundo lugar, estar-se-á dando ao administrador judicial o poder de sumariamente impedir a responsabilização

\footnotetext{
${ }^{339}$ VERÇOSA, Haroldo Malheiros Duclerc. In: SOUZA JUNIOR, Francisco Satiro de, e PITOMBO, Antônio Sérgio de A. Moraes. (coord.). Comentários à Lei de Recuperação de Empresas e Falência. Lei 11.101/2005. - Artigo por Artigo. $2^{\mathrm{a}}$ ed. São Paulo: Revista dos Tribunais, 2.007, p. 173.

${ }^{340}$ MANDEL, Julio Kahan. Nova Lei de Falências e Recuperação de Empresas anotada. Lei n. 11.101, de 9 de fevereiro de 2005. $1^{\mathrm{a}}$ ed. São Paulo: Saraiva, 2.005, p. 54-55.
} 
penal de quem tenha, em tese, cometido um crime. Basta, para tanto, que ele, por falha involuntária ou por qualquer outro motivo, deixe de referir-se a "atos que possam constituir crime relacionando com a recuperação judicial ou com a falência", e, consequentemente, de imputá-los a alguém. ${ }^{341}$

\subsubsection{Arrecadação, avaliação e guarda dos bens do falido.}

Uma das funções de suma importância conferida ao administrador judicial consiste na arrecadação de bens e documentos do falido ${ }^{342}$. Com a decretação da quebra, o falido não perde imediatamente a propriedade de seus bens e direitos (que ocorrerá quando da alienação dos mesmos), mas sim a sua posse, e, consequentemente, o direito de administrá-los ou deles dispor ${ }^{343}$. Justamente por isso, ato contínuo à assinatura do termo de compromisso, o administrador judicial é imitido na posse dos bens e documentos ${ }^{344}$. A necessidade de rapidez na imissão e arrecadação se justifica para se evitar possíveis depredações, furtos, perecimento de bens, dentre outros.

Note-se que, inclusive nos casos em que o juiz falimentar determinar a continuação provisória das atividades do falido ${ }^{345}$, a arrecadação e consequente avaliação dos bens devem ser feitas pelo administrador judicial ${ }^{346}$.

Como em grande parte das falências os bens e/ou documentos encontram-se guardados em locais fechados ou em bens imóveis de terceiros, o administrador judicial poderá estar acompanhado de oficial de justiça, e ainda, se a situação exigir, de força policial.

No momento da arrecadação, o administrador judicial deverá fazer o inventário de todo o "patrimônio falimentar", isto é, dos bens ${ }^{347}$ (sejam eles corpóreos ou incorpóreos,

\footnotetext{
341 TOLEDO, Paulo Fernando Campos Salles de. In: TOLEDO, Paulo Fernando Campos Salles de, e ABRÃO, Carlos Henrique (coord.). Comentários à Lei de Recuperação de Empresas e Falência. $4^{\mathrm{a}}$. ed. São Paulo: Saraiva, 2.010, p. 117-118.

${ }^{342}$ Art. 22, inc. III, al. "f”, c/c art. 108, LRE.

${ }^{343}$ Art. 103, "caput", LRE.

${ }^{344}$ Art. 108, "caput", LRE.

${ }^{345}$ Art. 99, inc. XI, LRE.

346 BERTOLDI, Marcelo. In: CÔRREA-LIMA, Osmar Brina e LIMA, Sérgio Mourão Corrêa (coord.). Comentários à Nova lei de Falência e Recuperação de Empresas: Lei no 11.101, de 09 de fevereiro de 2005. $1^{\mathrm{a}}$ ed. Rio de Janeiro: Forense. 2.009, p. 816.
} 
móveis ou imóveis, direitos e/ou também ações) ${ }^{348}$ e dos documentos encontrados (incluindo-se aí todos os livros sociais).

Deverão ser arrecadados os bens penhorados, os bens indicados como propriedade de terceiros ou reclamados por estes, que deverão ser objeto de pedido de restituição, conforme previsto no artigo 85 da $\mathrm{LRE}^{349}$; e os bens da massa falida em poder de terceiros. Somente não serão arrecadados os bens absolutamente impenhoráveis ${ }^{350 \_}{ }^{351}$ e os que constituam patrimônio de afetação, constituídos para cumprimento de destinação especifica, nos termos do artigo 119 , inciso IX da LRE ${ }^{352}$.

Consoante acima exposto, além dos bens corpóreos, o administrador judicial deve arrecadar e avaliar os bens incorpóreos da massa falida (marcas, patentes, modelos de utilidades e desenhos industriais), quando existentes. Caso não tenha a "expertise" necessária para tanto, o administrador judicial deverá contar com o trabalho de um auxiliar especializado em avaliação de bens incorpóreos, haja vista que não obstante o decréscimo econômico que tais bens possam sofrer em razão da quebra de seu detentor, em muitos casos poderão ser avaliados e alienados judicialmente por valores significativos ${ }^{353}$.

Se o falido detiver quotas de outras sociedades, o administrador judicial deverá providenciar a sua arrecadação e a apuração de haveres de forma amigável (isto é, solicitando que os sócios do falido realizem a apuração de haveres) ou judicial (quando a

\footnotetext{
${ }^{347}$ Segundo Trajano de Miranda Valverde, "o termo 'bens' exprime aqui todos os valores econômicos que formam o ativo do patrimônio do falido, compreendendo, assim, os direitos e ações." VALVERDE, Trajano de Miranda. Comentários à Lei das Falências. (Decreto-lei n ${ }^{\circ}$ 7.661, de 21 de junho de 1945). Vol. II (art. 62 a 176). $4^{a}$ ed. rev. e atualizada por J. A. Penalva Santos e Paulo Penalva Santos. Rio de Janeiro: Revista Forense, 1999, p. 18.

${ }_{348}$ TEPEDINO, Ricardo. In: TOLEDO, Paulo Fernando Campos Salles de, e ABRÃO, Carlos Henrique (coord.). Comentários à Lei de Recuperação de Empresas e Falência. $4^{\mathrm{a}}$ ed. São Paulo: Saraiva, 2.010, p. 404.

${ }^{349}$ BERTOLDI, Marcelo. In: CÔRREA-LIMA, Osmar Brina e LIMA, Sérgio Mourão Corrêa (coord.). Comentários à Nova lei de Falência e Recuperação de Empresas: Lei no 11.101, de 09 de fevereiro de 2005. $1^{\mathrm{a}}$ ed. Rio de Janeiro: Forense. 2.009, p.815.

${ }^{350}$ Art. $108, \S 3^{\circ}$, LRE.

${ }^{351}$ Sobre bens impenhoráveis, vide art. 649 do CPC e art. $1^{\circ}$ da Lei 8.009/90.

$352 \mathrm{O}$ administrador apenas arrecadará o saldo a favor da massa falida ou inscreverá na classe própria o crédito que contra ela remanescer, quando do cumprimento de sua finalidade. Sobre esta matéria, cf. Sérgio CAMPINHO. Falência e Recuperação de Empresa: O novo regime da insolvência empresarial. $6^{\mathrm{a}}$ ed. Rio de Janeiro: Renovar, 2.012, p. 368.

${ }^{353}$ A respeito dos procedimentos adotados para a avaliação de bens intangíveis na falência e na recuperação judicial, cf. LUCENA, Adriana. $\mathrm{O}$ tratamento legal da propriedade intelectual na falência e na recuperação de empresas. In: TOLEDO, Paulo Fernando Campos Salles de; e SOUZA JUNIOR, Francisco Satiro de (coords.). Direito das Empresas em Crise: Problemas e Soluções. 1a ed. São Paulo: Quartier Latin, 2.012, p. 27-30.
} 
via amigável não surtir efeitos ou quando o contrato social não discipline a matéria) $)^{354}$. Este raciocínio é aplicável para os sócios comanditários e os sócios quotistas, por determinação expressa do artigo 123 da LRE, e também aos sócios comanditados, aos sócios de sociedades em nome coletivo e aos de sociedades simples ${ }^{355}$. Em se tratando de ações de sociedades anônimas ou de comanditas por ações, o administrador judicial deverá arrecadá-las e providenciar a sua venda em Bolsa, na hipótese de sociedades abertas e, no caso das companhias de capital fechado, serão arrecadadas e vendidas da mesma forma prevista em lei para a alienação de outros ativos (artigos 139 e seguintes da LRE).

Quanto à arrecadação ou não dos bens particulares dos sócios, deveremos analisar o tipo societário em cada caso concreto. A regra é não serem arrecadados os bens dos sócios das falidas, haja vista que o patrimônio pessoal daqueles se distingue e não se mistura com os bens destas. Somente serão arrecadados os bens dos sócios de sociedade em nome coletivo ${ }^{356}$, dos sócios comandidatos de sociedades em comandante simples ${ }^{357}$, e dos empresários individuais, haja vista a responsabilidade ilimitada delas decorrente ${ }^{358}$.

Tanto o falido $^{359}$ como do Ministério Público ${ }^{360}$ podem acompanhar a arrecadação e a avaliação dos bens.

Note-se que a arrecadação deve ser feita em todo o território nacional e também no exterior, sem ser necessária a expedição de carta precatória para tal ato, em face da competência universal do juízo falimentar. E não obstante saibamos da dificuldade existente principalmente em falências de grande porte para a localização de bens, compete também ao administrador judicial a busca e arrecadação dos bens e documentos situados no exterior, com o auxilio, inclusive, de empresas estrangeiras especializadas no rastreamento e recuperação de ativos em falências.

\footnotetext{
${ }^{354}$ Art. 123, LRE.

${ }^{355}$ FRONTINI, Paulo Salvador. In: SOUZA JUNIOR, Francisco Satiro de, e PITOMBO, Antônio Sérgio de A. Moraes. (coord.). Comentários à Lei de Recuperação de Empresas e Falência. Lei 11.101/2005. - Artigo por Artigo. $2^{\mathrm{a}}$ ed. São Paulo: Revista dos Tribunais, 2.007, p. 457.

${ }^{356}$ Art. 1039, CC.

${ }^{357}$ Art. $1045, \mathrm{CC}$.

${ }^{358}$ Art. 81, LRE.

${ }^{359}$ Art. 108, § $2^{\circ}$, LRE.

${ }^{360} \mathrm{Na}$ LF, a presença do Ministério Público era obrigatória (art. 70).
} 
A arrecadação deve ser acompanhada da devida avaliação dos bens, sempre que possível, de forma individualizada ${ }^{361}$. Caso não seja factível a apresentação do respectivo laudo de avaliação dos bens no ato da arrecadação, o administrador judicial deverá apresentá-lo no prazo máximo de trinta dias. Referido auto de arrecadação deverá ser assinado pelo administrador judicial, pelo falido ou seus representantes e por terceiros que auxiliarem ou presenciarem o ato. Com relação aos bens imóveis, o administrador judicial terá o prazo de quinze dias contados da arrecadação para apresentar as devidas certidões imobiliárias atualizadas.

Ele deverá avaliar os bens arrecadados e, caso não tenha condições técnicas para tanto, poderá contratar avaliadores para este mister ${ }^{362}$, sempre com devida autorização judicial (cf. tópico 3.4.1.7). Para Paulo Fernando Campos Salles de Toledo, a preferência por avaliadores oficiais não tem justificativa; afinal seriam melhores os avaliadores apenas por exercerem oficialmente essa função ${ }^{363}$ Realmente, não nos parece ter muita importância na prática ser "oficial” ou não - o que deve contar é a especialização do avaliador e a real contribuição que possa vir a dar ao caso concreto.

Embora a LRE preveja preferencialmente a alienação da empresa em bloco ${ }^{364} \mathrm{e}$ a consequente avaliação em bloco ${ }^{365}$, a avaliação dos bens deve ser feita de forma individual obrigatoriamente no que diz respeito aos bens gravados com garantia real, haja vista que os créditos deste tipo de garantia concorrem nesta classe até o limite do valor do bem gravado ${ }^{366}$.

\footnotetext{
${ }^{361}$ Art. $110, \S 3^{\circ}$, LRE.

${ }^{362}$ Art. 22, inc. III, al. "g" e "h', LRE.

${ }^{363}$ Conforme Paulo Fernando Campos Salles de Toledo: "Inexiste experiência prática a respeito, uma vez que, normalmente, os avaliadores, nos diversos processos em que atuam, são peritos de confiança do juízo. A alusão ao qualificativo de oficiais pode deixar de ter repercussão concreta." In: TOLEDO, Paulo Fernando Campos Salles de, e ABRÃO, Carlos Henrique (coord.). Comentários à Lei de Recuperação de Empresas e Falência. $4^{\mathrm{a}}$ ed. São Paulo: Saraiva, 2.010, p. 113.

${ }^{364}$ Art. 140, LRE.

${ }^{365}$ Vera Helena de Mello Franco destaca que "quando a lei fala em 'avaliação em bloco', tem em vista a avaliação do estabelecimento empresarial em sua unidade, como universalidade de fato, circunstancias em que se levará em conta também o valor do ponto ou local de negócio, tal como resulta do direito ao exercício da ação renovatória, de molde a preservar a clientela, tendo em vista que o aviamento é um valor a ser considerado em si mesmo.". Franco, Vera Helena de Mello In: SOUZA JUNIOR, Francisco Satiro de, e PITOMBO, Antônio Sérgio de A. Moraes. (coord.). Comentários à Lei de Recuperação de Empresas e Falência. Lei 11.101/2005. - Artigo por Artigo. $2^{\mathrm{a}}$ ed. São Paulo: Revista dos Tribunais, 2.007, p. 430.

${ }^{366}$ Art. $108, \S 5^{\circ}, \mathrm{c} / \mathrm{c}$ art. 83, § $1^{\circ}$, LRE.
} 
Incumbe também ao administrador judicial a "guarda" dos bens arrecadados, diretamente ou por meio de pessoa por ele escolhida, sob sua responsabilidade pessoal. Ele pode, inclusive, removê-los "desde que haja necessidade de sua melhor guarda e conservação" ${ }^{367}$. Ressalte-se que o próprio falido ou o representante legal da sociedade falida podem figurar como depositários dos bens; todavia, mesmo nesta hipótese, a responsabilidade ainda será do administrador judicial ${ }^{368}$.

Verifica-se que a Seção VII da LRE cita a expressão "custódia dos bens" enquanto o artigo 108 da LRE fala em "guarda" dos bens arrecadados e em "depositário dos bens" e o artigo 112 refere-se a "depósito". Não obstante a multiplicidade de figuras jurídicas utilizadas, o administrador judicial exerce a função de depositário judicial, ainda que se trate de "depósito atípico" ${ }^{369}$, que tem por objeto a guarda e conservação da coisa, por determinação legal.",370. O administrador judicial será apenas responsabilizado civilmente, por culpa ou dolo, não havendo que se falar em prisão civil, conforme Súmula vinculante 25 do Supremo Tribunal Federal ${ }^{371}$.

O administrador judicial não será o depositário dos bens, na hipótese de substancias entorpecentes arrecadadas nos "estabelecimentos hospitalares, de pesquisa, de ensino, ou congêneres" das empresas falidas, as quais deverão ficar sob a guarda e depósito de "autoridade sanitária competente", conforme prescreve expressamente o inciso II, do artigo 69 da Lei 11.343/2006.

Justamente por deter a guarda dos bens e por ter como atribuição a prática de todos os atos conservatórios de direitos e ações, bem como de diligências e medidas necessárias para a proteção da massa e eficiência da administração, o administrador

\footnotetext{
${ }^{367}$ Art. $108, \S 1^{\mathrm{o}}$, c/c art. 112, LRE.

${ }^{368}$ BEZERRA FILHO, Manoel Justino, Lei de Recuperação de Empresas e Falências Comentada, $5^{\mathrm{a}}$ ed. São Paulo: Revista dos Tribunais, 2.008, p. 287.

369 TEPEDINO, Ricardo. In: TOLEDO, Paulo Fernando Campos Salles de, e ABRÃO, Carlos Henrique (coord.). Comentários à Lei de Recuperação de Empresas e Falência. $4^{\mathrm{a}}$ ed. São Paulo: Saraiva, 2.010, p. 409.

${ }^{370}$ Segundo Orlando Gomes, a "custódia" é um contrato atípico que se aproxima do depósito "porquanto seu fim econômico é a guarda de valores". Já o "depósito" é um contrato que não pode ter por objeto coisas móveis; e o "sequestro" é o depósito de coisa litigiosa, mas tem natureza onerosa. O termo "depósito judicial", ainda segundo ele, é usado para "nomear o depósito de coisa sobre cuja propriedade litigam duas pessoas, resulte de acordo entre os interessados ou de decisão judicial" (g/n). GOMES, Orlando. CONTRATOS. $12^{\mathrm{a}}$ ed. Rio de Janeiro: Forense, 2008, p. 376-386.

${ }^{371}$ Súmula vinculante 25, STF: "É ilícita a prisão civil de depositário infiel, qualquer que seja a modalidade do depósito."
} 
judicial deve zelar pela manutenção do ativo, na medida da capacidade da massa. Em se tratando de bens incorpóreos, por exemplo, o trabalho do administrador judicial não se encerra na arrecadação e avaliação; ele deve estar atento aos prazos de vigência e renovação, e respectivos registros, junto ao Instituto Nacional de Propriedade Industrial (INPI), já que não há no ordenamento pátrio previsão de isenção às massas falidas do dever de renovação e do pagamento das taxas, nem tampouco suspensão do prazo previsto no art. 143 da Lei $9.279 / 96^{372}$. É dever do administrador judicial, portanto, providenciar, se for o caso, "a alienação antecipada de bens arrecadados para que a massa falida tenha caixa suficiente para arcar com as retribuições devidas ao INPI", consoante entende a jurisprudência paulista ${ }^{373}$. O problema se verifica nas hipóteses em que a massa falida não detém bens suficientes para arcar com os custos necessários para o registro desses bens: nestes casos, como não é possível impor ao administrador judicial, ao falido, e/ou aos credores a obrigação pessoal de tal pagamento, a massa falida perderá o direito sobre a marca e todos perderão, posto que, em muitos casos os bens imateriais ostentam grande valor econômico. Melhor seria se o INPI efetuasse o registro por determinação judicial e habilitasse o crédito dele decorrente no processo falimentar, "obtendo o privilégio de ser considerado como crédito extraconcursal, conforme dispõe o art. 84, inciso III da Lei $\mathrm{n}^{\circ}$ $11.101 / 2005^{\prime 374}$.

\footnotetext{
${ }^{372}$ TJSP, AI 403.886-4/5-00, Rel. Marques Neto, 8 a Câmara de Direito Privado, j. 08/03/06, v.u.

${ }^{373}$ Confira-se, neste sentido, trecho do voto do Rel. Des. Manoel de Queiroz Pereira Calças nos autos do Agravo de Instrumento ${ }^{\circ}$ 575.513.4/9-00, julgado pela Câmara Especial de Falências e Recuperação Judicial de Direito Privado do Tribunal de Justiça do Estado de São Paulo, em 05/05/09, v.u: “(...) Não há no direito positivo brasileiro qualquer regra que autorize o Juízo da falência a decretar a inexigibilidade do pagamento das retribuições pela expedição do certificado de registro da marca e pelo primeiro decênio de sua vigência, previstos no art.161 da LPI. Também inexiste qualquer fundamento legal que permita ao Juízo da falência suspender o curso do prazo previsto no art. 143, inciso II, da LPI, que prevê a caducidade do registro da marca em face da interrupção de seu uso por mais de cinco anos consecutivos. Diante disso, cabe ao Administrador Judicial, a teor do art. 22, III, alíneas "I" e "o", da Lei n 11.101.2005, praticar todos os atos conservatórios de direitos e ações e requerer todas as medidas e diligências necessárias à proteção da massa ou à eficiência da administração. Isto significa que o Administrador Judicial deve providenciar a alienação antecipada de bens arrecadados para que a Massa Falida tenha caixa suficiente para arcar comas retribuições devidas ao INPI em decorrência do registro marcário, bem como deve promover o procedimento administrativo necessário à prorrogação do registro que é previsto no art. $133, \S 1^{\circ}$, da Lei de Propriedade Industrial. Se necessário for, deve contratar advogado para acompanhar o procedimento junto ao INPI. Anote-se ainda que o prazo previsto no ar. 143, inciso I, da LPI, é decadencial, mercê do que, não enseja interrupção ou suspensão por decisão judicial.”

${ }^{374}$ LUCENA, Adriana. O tratamento legal da propriedade intelectual na falência e na recuperação de empresas. In: TOLEDO, Paulo Fernando Campos Salles de; e SOUZA JUNIOR, Francisco Satiro de (coords.). Direito das Empresas em Crise: Problemas e Soluções. 1ª ed. São Paulo: Quartier Latin, 2012, p. 24-25.
} 


\subsubsection{Realização do ativo e pagamento dos credores.}

A realização do ativo e o pagamento dos credores também constituem tarefas de grande relevância do administrador judicial na falência ${ }^{375}$, em face do escopo da LRE de "preservar e otimizar a utilização produtiva dos bens, ativos e recursos produtivos, inclusive os intangíveis"376.

Com efeito, a maximização do ativo ${ }^{377}$ traz vantagens tanto para o falido, que terá aumentada a chance de ter a falência extinta e ser reabilitado para o exercício da atividade empresarial, como para os credores, que receberão um valor que mais se aproxime de seu crédito, com a consequente proteção do crédito público ${ }^{378}$; e a pro atividade de um bom administrador certamente será notada quando da realização do ativo da forma mais célere e lucrativa possível.

Merece destaque a possibilidade da continuação provisória das atividades do falido a ser exercida pelo administrador judicial ${ }^{379}$. Trata-se de medida excepcional e que somente é admitida em caráter provisório e com o intuito de obter-se um melhor resultado na alienação do ativo.

A LRE é omissa em regular a continuação provisória das atividades do falido; apenas há menção da continuação provisória no artigo 99, incisos VI e XI, e no artigo 150 da $\operatorname{LRE}^{380}$. As mesmas críticas feitas no tópico 3.4.2.3, sobre a gestão da empresa em recuperação pelo administrador judicial, podem ser feitas aqui com as devidas adaptações.

\footnotetext{
${ }^{375}$ Art. 22, inc. III, al. "i”, LRE.

${ }^{376}$ Art. 75, LRE.

377 Como já exposto no tópico 1.1, a maximização dos ativos do falido é um dos princípios norteadores da falência e se encontra relacionado no relatório do projeto de lei complementar n. 71/2003.

378 BERNARDI, Ricardo. In: SOUZA JUNIOR, Francisco Satiro de, e PITOMBO, Antônio Sérgio de A. Moraes. (coord.). Comentários à Lei de Recuperação de Empresas e Falência. Lei 11.101/2005. - Artigo por Artigo. $2^{\text {a }}$ ed. São Paulo: Revista dos Tribunais, 2007, p. 139.

${ }^{379}$ Art. 99, inc. XI, LRE.

${ }^{380}$ A este respeito, verifique-se os comentários de Adriana Valéria Pugliesi: “A gestão desse patrimônio, por via de disciplina de continuação provisória das atividades do falido, é matéria a ser apreciada e instituída por reforma legal, para a qual se sugerem os seguintes fundamentos: (i) que as relações de débito e crédito decorrentes deste negócio possam alimentar-se e se sustentar de forma isolada em relação àquelas precedentes (que deverão ser satisfeitas na falência); (ii) as obrigações que eventualmente nascidas para credores (empregados e tributos, v.g.) resultantes desta operação devem ser satisfeitas apenas e tão somente com recursos gerados pela própria atividade econômica desenvolvida pela massa; e, finalmente (iii) que a administração de tal negócio, tanto do ponto de vista de gestão subjetiva quanto da contabilização, seja totalmente desvinculada e separada dos credores da falida". PUGLIESI, Adriana Valéria. Direito Falimentar e Preservação da Empresa. São Paulo: Quartier Latin, 2.013, p. 186.
} 
Note-se que na falência, a situação é ainda mais complexa, posto que a finalidade da continuação provisória das atividades pelo administrador judicial é justamente viabilizar a venda dos ativos por um melhor valor. Poderão, então, os credores responsabilizar o administrador judicial caso o resultado obtido em leilão não seja satisfatório? Será o administrador judicial responsável pelos seus atos e débitos contraídos nas mais diversas esferas, notadamente, a trabalhista e a tributária, da mesma forma que são aos sócios ou seus administradores e diretores das sociedades em geral $^{381}$ ? Como será fiscalizada a atuação do administrador judicial? Terá o administrador judicial a "expertise" necessária para a manutenção dessas atividades?

Acreditamos que nem sempre o melhor "administrador judicial" será o profissional mais indicado para prosseguir com as atividades do falido e maximizar o ativo posto que esta hipótese difere totalmente das funções a serem exercidas pelo administrador judicial. Consoante ressalta Pedro Paes de Vasconcelos ao discorrer sobre o administrador judicial português, nos casos de venda da empresa em funcionamento, "é imprescindível que a empresa não deixe de ser gerida empresarialmente" ${ }^{382}$. Ora, a LRE é clara no sentido de que o administrador judicial deve ser escolhido com base nos requisitos de idoneidade e de especialização para a função de administrador judicial e não de administrador de empresas. Na falência, como estamos a estudar neste capítulo, as suas funções primordiais são a administração e representação da massa falida para posterior pagamento dos credores, tarefas estas que nada coincidem com o exercício das atividades negociais do falido.

Acreditamos que a nomeação de um gestor $^{383}$ que seja especializado em empresas em crise e que fosse diretamente fiscalizado pelo administrador judicial seria a melhor opção.

Determina a LRE que a realização do ativo deve ocorrer "logo após a arrecadação dos bens, com a juntada do respectivo auto ao processo de falência" ${ }^{384}$ e terá

\footnotetext{
${ }^{381}$ No que pertine à responsabilidade do administrador judicial, vide tópico 3.6 infra.

382 VASCONCELOS, Pedro Pais de. Responsabilidade civil do administrador de insolvência. In: II Congresso de Direito da Insolvência. Serra, Catarina (coord.). Coimbra: Almedina, 2014, p. 194.

383 A LF previa, em seu art. 74, § $2^{\circ}$, que a continuação do negócio seria exercida por um "gerente", contratado pelo síndico e sob a sua imediata fiscalização.

${ }^{384}$ Art, 139, LRE.
} 
inicio independentemente da formação do quadro-geral de credores ${ }^{385}$. Todavia, mesmo sendo uma das mais aplaudidas inovações da LRE, haja vista que o artigo 114 da LF apenas permitia a realização dos ativos após o final do procedimento de verificação dos créditos, do inquérito judicial e da apresentação do relatório do síndico constante do artigo 63, inciso XIX, da LF, o inicio da alienação dos ativos geralmente não é imediato à arrecadação seja pela necessidade de prévia avaliação dos bens, pela necessidade de se avaliar a conveniência na forma de serem alienados os ativos, dentre outros ${ }^{386}$. Os bens perecíveis, de fácil deterioração, rápida desvalorização de bens arrecadados, ou ainda de conservação arriscada ou dispendiosa, poderão ser vendidos antecipadamente, após a arrecadação e avaliação, mediante autorização judicial e com a prévia oitiva do comitê, se houver, e do falido, no prazo de 48 (quarenta e oito) horas ${ }^{387}$.

Competirá ao administrador judicial organizar a venda a fim de que ela seja feita de acordo com a ordem de preferência elencada no artigo 140 da LRE, qual seja: i) a venda dos estabelecimentos da empresa deve ser feita, preferencialmente, em bloco; ii) a venda das filiais ou unidades produtivas da empresa será feita de forma isolada; iii) os bens que integram cada um dos estabelecimentos da empresa serão feitos em bloco; iv) os bens serão alienados de forma individual. Verificamos aqui um poder discricionário do administrador judicial, ainda que limitado, haja vista que a ordem de preferência da venda dos bens, como o próprio nome já sugere, não é taxativa, cabendo a ele analisar e decidir qual a forma de obter uma maior arrecadação. Não obstante tal poder, como ressalta Rachel Sztajn a "escolha por qualquer das alternativas, embora não haja menção em lei, deverá ser justificada, fundamentada, dado o interesse dos credores no resultado da liquidação dos ativos" 388 .

A alienação do ativo é feita em juízo, sempre com a oitiva do administrador judicial, através de leilão, propostas fechadas ou pregão ${ }^{389}$. Qualquer outra modalidade deverá ser requerida de forma justificada pelo administrador judicial ou pelo comitê de

\footnotetext{
${ }^{385}$ Art. $140, \S 2^{\circ}$, LRE

${ }^{386}$ SZTAJN, Raquel. In: TOLEDO, Paulo Fernando Campos Salles de, e ABRÃO, Carlos Henrique (coord.). Comentários à Lei de Recuperação de Empresas e Falência. $4^{a}$ ed. São Paulo: Saraiva, 2.010, p. 493.

${ }^{387}$ ARt. 113, LRE.

${ }^{388}$ SZTAJN, Raquel. In: TOLEDO, Paulo Fernando Campos Salles de, e ABRÃO, Carlos Henrique (coord.). Comentários à Lei de Recuperação de Empresas e Falência. $4^{\mathrm{a}}$ ed. São Paulo: Saraiva, 2.010, p. 494.

${ }^{389}$ Art. 142, LRE.
} 
credores, se houver, e dependerá de autorização judicial; o juiz também homologará outra forma de alienação desde que aprovada em assembleia-geral de credores ${ }^{390}$.

Outrossim, é necessário ter em mente que a realização do ativo não compreende apenas a venda dos bens arrecadados, mas também a cobrança dos créditos que o falido detenha. Caberá ao administrador judicial prudência ao analisar a real possibilidade de recebimento dos créditos que o falido detenha, no período de tempo mais exíguo possível sendo possível, se for o caso, a concessão de abatimento ou transigir sobre obrigações e direitos da massa falida, nas hipóteses de difícil liquidação. Obviamente, o pedido fundamentado de abatimento ou de transação deverá ser analisado e autorizado previamente pelo juiz da falência, após a oitiva do falido e do comitê de credores, no prazo comum de 02 (dois) dias, nos termos do parágrafo $3^{\circ}$ do artigo 22 da LRE.

Na hipótese de o administrador judicial vislumbrar a possibilidade de produção de renda em benefício da massa falida, poderá alugar ou celebrar contratos, sempre com prévia autorização do Comitê $\hat{e}^{391}$, como determina o artigo 114 da LRE. Os respectivos contratos não gerarão direito de preferência na compra, e não importarão disposição parcial ou total dos bens, que, por sua vez, poderão ser alienados a qualquer tempo, independentemente do prazo contratado. Outra não poderia ser a postura da lei, visto que a falência deve atender os princípios da celeridade e da economia processual.

Com o mesmo intuito de manutenção, preservação dos ativos e otimização, ou ainda para se reduzir ou evitar o aumento do passivo da massa falida, o administrador judicial poderá dar cumprimento a contratos bilaterais ou unilaterais, com a devida autorização do comitê de credores, se houver ${ }^{392}$.

Da mesma forma, se optar por não continuar a execução de contrato com reserva de domínio do vendedor, restituirá a coisa móvel comprada pelo falido, após ser ouvido o supra referido comitêt $\hat{e}^{393}$.

\footnotetext{
${ }^{390}$ Art. 144 e 145, LRE.

${ }^{391} \mathrm{Na}$ hipótese de não haver Comitê de Credores, caberá ao juiz exercer sua atribuição, conforme determina o artigo 28 da LRE.

${ }^{392}$ Art. 117 e 118, LRE.

${ }^{393}$ Art. 119, inc. IV, LRE.
} 
Igualmente seguindo o critério de benefício para a massa falida, o administrador poderá remir bens que estejam apenhados, penhorados ou legalmente retidos, mediante autorização judicial ${ }^{394}$. Neste sentido, Paulo Fernando Campos Salles de Toledo alerta para o fato de que esta atribuição será de difícil aplicação já que a LRE não prevê a venda diferenciada para os bens objeto de direitos reais de garantia, ao contrário do que previa a lei anterior ${ }^{395}{ }_{-}^{396}$.

O pagamento dos credores deverá ser feito pelo administrador judicial na forma prevista nos artigo 83 e 84 da LRE, após a realização das devidas restituições de bens e consolidação do quadro-geral de credores $^{397}{ }^{398}$, e, se houver saldo, deverá entregar para o falido ${ }^{399}{ }_{-}^{400}$.

\subsubsection{Representação da massa falida em juízo ou fora dele.}

Com a decretação da falência, o devedor perderá o direito de administrar seus bens ou deles dispor, detendo, no entanto, o direito de fiscalizar a administração da massa e requerer as providências necessárias para a conservação de seus direitos ou bens, além de poder intervir nos processos em que a massa falida seja parte ou interessada. ${ }^{401}$

A representação da massa falida (ente despersonalizado, sujeito de direitos e obrigações) passará a ser feita pelo administrador judicial, o qual deverá praticar todos os

\footnotetext{
${ }^{394}$ Art. 22, inc. III, al. “m”, LRE.

${ }^{395}$ Art. 120, LF.

396 TOLEDO, Paulo Fernando Campos Salles de. In: TOLEDO, Paulo Fernando Campos Salles de, e ABRÃO, Carlos Henrique (coord.). Comentários à Lei de Recuperação de Empresas e Falência. $4^{\mathrm{a}}$. ed. São Paulo: Saraiva, 2.010, p. 114.

${ }^{397}$ Art. 149, LRE.

${ }^{398}$ Com exceção aos créditos trabalhistas de natureza estritamente salarial vencidos nos 3 (três) meses anteriores à decretação da falência, os quais deverão ser pagos pelo administrador judicial, no limite de 5 (cinco) salários mínimos por trabalhador, assim que haja disponibilidade em caixa, "ex vi” do disposto o art. 151 da LRE.

${ }^{399}$ Art. 153, LRE.

$400 \mathrm{Na}$ hipótese de a falida ser sociedade empresária, o saldo deverá ser entregue a seus sócios proporcionalmente à parcela de cada um no capital social cf. art. 1108, CC e art. 215, LSA.

${ }^{401}$ Art. 103, LRE.
} 
atos e medidas necessários para a conservação e proteção dos diretos e interesses da massa falida $^{402}$.

É, por até se dizer, óbvio que o administrador judicial pode e deve praticar todas as medidas que forem necessárias visando à proteção da massa, à otimização dos ativos e a uma administração eficiente. Aliás, caso o administrador judicial não aplique toda a diligência que o caso requer, deverá ser responsabilizado por suas ações e/ou omissões.

Enfim, caberá ao administrador judicial defender os interesses da massa falida, sendo seu represente processual no polo ativo e passivo, em todas as ações judiciais que já estavam em andamento quando da decretação da falência da empresa, bem como interpondo as medidas extra e/ou judiciais que se fizerem necessárias ${ }^{403}$. Nas hipóteses em que o administrador judicial não for advogado ${ }^{404}{ }_{-}^{405}$ e/ou não se julgar apto a cumular as funções de representação legal e a administração da massa falida com a sua representação jurídica, poderá contratar um profissional, cujos honorários serão previamente aprovados pelo comitê de credores, ou, na sua falta, pelo juiz ${ }^{406 \_}{ }_{-}^{407}$. Na esfera judicial, deverá relacionar todos os processos em curso existentes, nos quais representará a massa falida ${ }^{408}$; e ainda que apresente tal relação, deverá ser intimado para representar a massa falida, em todas as ações, sob pena de nulidade processual, conforme determina o parágrafo único do artigo 76 da LRE.

\subsubsection{Entrega ao seu substituto de todos os bens e documentos da massa em seu poder.}

\footnotetext{
${ }^{402}$ Art. 22, inc. II, al. "l" e "o", LRE.

403 Art. 12, inc. III, CPC.

${ }^{404}$ Art. 36, CPC.

405 A capacidade postulatória do administrador judicial que atua como procurador da massa falida é reconhecida pela jurisprudência, e se comprova mediante a apresentação de cópia do ato de nomeação e do termo de compromisso. Neste sentido: STJ, AgrG no Ag 794195/RJ 2006/0123761-9, Rel Min. Paulo Furtado, Terceira Turma, DJe 04/08/09.

${ }^{406}$ Art. 22, inc. III, al. "n”, LRE.

${ }^{407}$ Note-se que a competência para aprovar os honorários judiciais foi alterada com a LRE, já que a LF, em seu art. 63, inc. XVI, previa a aprovação única e exclusiva pelo juiz.

${ }^{408}$ Art. 22, inc. III, al. "c", LRE.
} 
Caso ocorra a substituição ou a destituição do administrador judicial, este deverá entregar a seu substituto todos os bens e documentos da massa que estiverem em seu poder, bem como dar ao novo auxiliar do juízo todas as informações necessárias para o desempenho de suas atribuições, sob pena de responsabilidade ${ }^{409}$, nos termos do artigo 32 da LRE.

\subsubsection{Apresentação de conta demonstrativa da administração, da prestação final de contas e de relatório final da falência.}

Nas hipóteses em que haja a continuação dos negócios ou sempre que houver movimentação financeira, o administrador judicial deverá apresentar, até o décimo dia do mês subsequente, "conta demonstrativa de administração, que especifique com clareza receita e a despesa" ${ }^{, 410}$.

Também é dever do administrador judicial a prestação de contas final na falência, no prazo de 30 dias a contar do pagamento aos credores com o produto da realização do ativo $^{411}$. Referidas contas deverão estar acompanhadas dos devidos documentos comprobatórios e serão prestadas em autos apartados. Segundo Osmar Brina e Lima Corrêa-Lima, elas devem ser apresentadas em forma mercantil e observar, "tanto quanto possível" as regras de escrituração dos artigos 1183 e 1184 do Código Civil ${ }^{412}$. Elas poderão ser objeto de impugnação de qualquer interessado ou de parecer contrário do Ministério Público, e serão julgadas por sentença pelo magistrado. Caso sejam rejeitadas, a sentença fixará as responsabilidades do administrador judicial, podendo determinar a indisponibilidade ou sequestro de seus bens, e servirá como titulo executivo para indenização da massa.

Na falência, a última atividade do administrador judicial será a apresentação do relatório final, no qual deverá indicar o valor do ativo o do produto de sua realização, o valor do passivo e o dos pagamentos feitos aos credores, além de especificar, de forma

\footnotetext{
${ }^{409}$ Art. 22, inc. III, al. “q”, LRE.

${ }^{410}$ Art. 22, inc. III, al. "p", LRE.

${ }^{411}$ Art. 22, inc. III, al. "r" c/c art. 154, LRE.

412 CÔRREA-LIMA, Osmar Brina. In: CÔRREA-LIMA, Osmar Brina e LIMA, Sérgio Mourão Corrêa (coord.). Comentários à Nova lei de Falência e Recuperação de Empresas: Lei $n^{o} 11.101$, de 09 de fevereiro de 2005. $1^{\mathrm{a}}$ ed. Rio de Janeiro: Forense, 2.009, p.1030.
} 
justificada, as responsabilidades pendentes do falido, para as hipóteses de o ativo não tiver sido suficiente para pagar o passivo ${ }^{413}$. Este relatório deverá ser apresentado no prazo de 10 (dez) dias do julgamento de procedência das contas do administrador judicial. Caso o administrador judicial não apresente o relatório final ou na hipótese de suas contas serem julgadas “más”, ele será destituído da função e o relatório final será apresentado pelo seu substituto e não mais pelo Ministério Público, como determinava a lei anterior ${ }^{414}{ }^{415}$.

A aprovação judicial das contas é condição "sine qua non" para o administrador judicial não perder o direito à remuneração, conforme dispõe o artigo 24 , parágrafo $4^{\circ}$ da LRE.

Esta prestação de contas também será devida nas hipóteses de substituição, destituição ou renúncia do cargo.

\subsection{Deveres e atribuições implícitos.}

Uma função relevante do administrador judicial e que não está prevista de forma expressa na LRE é o atendimento e o fornecimento dos documentos aos exfuncionários da empresa falida. Caberá a ele dar baixa na carteira de trabalho, proceder à rescisão do contrato de trabalho para a liberação do Fundo de Garantia por Tempo de Serviço, preencher formulário para o requerimento do seguro-desemprego, fornecer as declarações para fins de aposentadoria, etc. ${ }^{416}$. Com relação a essas últimas declarações, entende-se que o administrador judicial apenas poderá prestá-las nas hipóteses em que exista a respectiva documentação comprobatória; nos casos em que os documentos não estejam de posse do administrador judicial (por já não existirem quando da arrecadação dos bens da falida ou por estarem em lugar incerto e não sabido) será necessário que o exfuncionário tome as medidas cabíveis visando à sua restauração ou a sua substituição (por sentença judicial).

\footnotetext{
${ }^{413}$ Art. 155, LRE.

${ }^{414}$ Art. 131, § único, LF.

415 CÔRREA-LIMA, Osmar Brina. In: CÔRREA-LIMA, Osmar Brina e LIMA, Sérgio Mourão Corrêa (coord.). Comentários à Nova lei de Falência e Recuperação de Empresas: Lei $n^{\circ} 11.101$, de 09 de fevereiro de 2005. $1^{\mathrm{a}}$ ed. Rio de Janeiro: Forense, 2.009, p.1.036.

416 Neste sentido, cf. KUGELMAS, Alfredo Luiz e ARRUDA PINTO, Gustavo Henrique Sauer de. Administrador judicial na recuperação judicial: Aspectos Práticos. In: DELUCCA, Newton de, e DOMINGUES, Alessandra de Azevedo (coord.). Direito Recuperacional. Aspectos teóricos e práticos. $1^{\mathrm{a}} \mathrm{ed}$. São Paulo: Quartier Latin, 2.009, p. 232-233.
} 
Ademais, para que seja protegida a massa e haja uma eficiente administração, conforme preconiza a alínea "o" do inciso III do artigo 22 da LRE, Luiz Alfredo Kugelmas e Gustavo Henrique Sauer de Arruda Pinto ressaltam a necessidade de expedição de ofícios não contemplados na LRE para inúmeros outros órgãos dentre os quais podemos citar: instituições financeiras, Delegacia da Receita Federal, DETRANs, Cartórios de Protestos, etc. $^{417}$.

Mais um dever implícito do administrador judicial é o de requerer o encerramento da recuperação judicial, na hipótese de todos incidentes processuais e demais pendências já estiverem sido julgados e após transcorrido o prazo de 2 (dois) anos de sua concessão $^{418}$ e a empresa não tiver assim requerido.

Por fim, da análise de todos os deveres e atribuições expostos nos tópicos acima, tanto na recuperação judicial como falência, podemos verificar que ao administrador judicial são impostos os deveres de obediência aos preceitos legais e também de diligência e lealdade na sua atuação, sob pena de responsabilidade. Este entendimento decorre da análise do artigo 31 da LRE, que, ao tratar da destituição do administrador judicial ou de membro do comitê de credores, explicita como causas: i)

417 "Tão logo assumem a administração judicial de uma falência tem os autores desse artigo por procedimento, nos exatos termos da alínea "o", do inciso III, do artigo 22 da Lei n 11.101./05, solicitar, no interesse da massa, a expedição de uma série de ofícios que não foram contemplados no referido diploma, tais como, v.g, somente para mencionar alguns, para as instituições depositárias de ações do sistema TELEBRAS, ELETROBRAS, e outras, de cotas do FINOR, FINAM e outros fundos, para as instituições financeiras onde a falida possuía contas solicitando documentação relativa a essas contas para a análise das movimentações feitas e a recuperação de valores indevidamente descontados pelos bancos, aos Cartórios de Registro de imóveis das localidades onde possuía a falida ou seus administradores negócios, ao DETRAN para que informe acerca dos veículos da empresa, seus representantes legais e filiais, aos Cartórios de Protesto das localidades onde a falida possuía negócios, para se saber a data do primeiro protesto contra ela tirado para efeito da contagem do termo legal da falência e a propositura, se for o caso, de ação revocatória para a recuperação de ativo desviado, ao INPI para a obtenção de informações acerca das marcas e patentes de titularidade da falida, que dependendo da empresa, podem possuir valor expressivo, à Caixa Econômica Federal para que informe todas as contas lá existentes em nome da falida referentes aos ex-funcionários não optantes do FGTS e o saldo relativo aos depósitos recursais da Justiça do Trabalho que deverá vir para a massa falida, e à Delegacia da Receita Federal para que encaminhe as declarações de rendimento da falida e dos seus sócios gerentes ou diretores, a partir do exame das quais é possível obter um grande número de informações acerca do ativo que não consta de documentos, ofícios e certidões, etc.”. KUGELMAS, Alfredo Luiz e ARRUDA PINTO, Gustavo Henrique Sader de. Administrador judicial na recuperação judicial: Aspectos Práticos. In: DELUCCA, Newton de, e DOMINGUES, Alessandra de Azevedo (coord.). Direito Recuperacional. Aspectos teóricos e práticos. $1^{\mathrm{a}}$ ed. São Paulo: Quartier Latin, 2.009, p. 229.

${ }^{418}$ Art. $61 \mathrm{c} / \mathrm{c}$ art. 63, LRE. 
"desobediência aos preceitos desta Lei", ii) "descumprimento de deveres, omissão, negligência"; e iii) "prática de ato lesivo às atividades do devedor ou a terceiros" 419.

Os deveres de lealdade e diligência do administrador judicial também podem ser extraídos da leitura do artigo 33 da LRE, que determina que a assinatura do termo de compromisso "de bem e fielmente desempenhar o cargo e assumir todas as responsabilidades a ele inerentes" deve ocorrer em 48 (quarenta e oito) horas da sua intimação.

Como se não bastasse os deveres de lealdade e de agir com boa-fé também estão implícitos no artigo 177 da LRE, que pune como crime falimentar o administrador judicial que adquirir bens da massa falida ou do devedor em recuperação judicial diretamente ou por meio de terceiros.

Outrossim, os deveres do administrador judicial, ainda que implícitos na LRE, podem ser verificados, sob outras duas óticas.

É cediço que o administrador judicial não pertence aos quadros da Justiça, não sendo, portanto, agente público, e nem ao menos assim equiparado, para fins penais (cf. tópico 3.5.2 infra). Todavia, não há como se negar o fato de ele é auxiliar eventual da justiça e que ao assumir de forma voluntária o "munus" público a ele conferido deve observar os deveres de lealdade, de obediência e de conduta ética dos servidores públicos $^{420}$, o que demonstra total sintonia com os deveres implícitos da LRE.

Por outro lado, nas hipóteses de efetiva gestão e continuação provisória dos negócios na falência ou no caso de gestão excepcional na recuperação judicial pelo administrador judicial, devem ser aplicados, por analogia, os seguintes deveres fiduciários do administrador de sociedades previstos no Código Civil e na Lei 6.404/76 ${ }^{421}$, em face da

\footnotetext{
${ }^{419}$ PIMENTA, Eduardo Goulart. Atribuições e Perfil do Administrador Judicial, Gestor Judicial e Comitê de Credores no Contexto da Lei n. 11.101/05. In: CASTRO, Moema A. S. De, e CARVALHO, William Eustáquio de (coord.). Direito Falimentar Contemporâneo. $1^{\text {a }}$ Ed. Porto Alegre: Sergio Antonio Fabris, 2008, p. 26.

${ }_{420}$ Sobre os deveres dos servidores públicos, cf. MEIRELLES, Hely Lopes. Direito Administrativo Brasileiro. 26a ed. São Paulo: Malheiros, 1.990, p. 436-438.

${ }^{421}$ Sobre deveres do administradores cf. ADAMEK, Marcelo Vieira Von. Responsabilidade civil dos administradores de S/A e as ações correlatas. 1ª ed. São Paulo: Saraiva, 2.009, p. 112-190.
} 
efetiva administração da sociedade: dever de diligência ${ }^{422}$, dever de dar cumprimento às finalidades das atribuições do cargo $^{423}$, dever de lealdade ${ }^{424}$, deveres próprios sobre conflito de interesses $^{425}$, e dever geral de vigilância ${ }^{426}$. Aliás, na falência, mesmo que não mantenha as atividades da falida, o administrador judicial efetivamente "administra" a massa falida, razão pela qual a aplicação desses deveres também se impõe. Apenas na recuperação judicial não conseguimos assim vislumbrar, haja vista a função essencial de fiscalização (das atividades do devedor e do plano) exercida pelo administrador judicial, ressalvada a hipótese excepcional de gestão acima aludida, o que não significa, por outro lado, que este órgão não deva obediência aos deveres, ainda que implícitos, constantes da LRE acima citados.

Obedecidas tais premissas, o administrador judicial deve exercer suas atividades com o mesmo dever de diligência do administrador de sociedade; deverá ele cumprir "o duty of care, do mesmo modo, com a mesma competência e proficiência", como destaca Pedro Pais de Vasconcelos ${ }^{427}$. Note-se que o cuidado e diligência a serem aplicados pelo administrador judicial (seja em decorrência dos preceitos da LRE acima expostos, seja pela aplicação por analogia dos deveres fiduciários do administrador) devem ser entendidos como superiores ao da figura do "pai de família", não obstante a redação dada pelo Código Civil e pela Lei 6.404/76, haja vista que suas atividades demandam uma especialização e exigem caráter profissional, verificando-se, pois "um plus acrescido à figura do bonus pater familias, diante da especificidade do mundo negocial" ${ }^{428}$. Em outras palavras, a diligência aqui discutida é "aquela própria de profissional, pois o administrador deve ser entendido como tal", devendo ser avaliada no caso concreto, consoante destaca Marcelo Vieira Von Adameck ${ }^{429}$ ou, como conclui Nelson Eizirik:

Assim, espera-se que os administradores não cometam graves erros de julgamento; porém, na medida em que tenham empregado o cuidado e a

\footnotetext{
${ }^{422}$ Art. 153, LSA e art. 1011, CC.

${ }^{423}$ Art. 154 , LSA.

${ }^{424}$ Art. 155, "caput", LSA.

${ }^{425}$ Art. 156, LSA.

${ }^{426}$ Art. 158, LSA.

427 VASCONCELOS, Pedro Pais de. Responsabilidade civil do administrador de insolvência. In: II Congresso de Direito da Insolvência. Serra, Catarina (coord.). Coimbra: Almedina, 2014, p. 197.

${ }^{428}$ RIBEIRO, Renato Ventura. Dever de Diligência dos Administradores de Sociedades. $1^{a}$ ed. São Paulo: Quartier Latin, 2006, p. 215.

${ }^{429}$ ADAMEK, Marcelo Vieira Von. Responsabilidade civil dos administradores de S/A e as ações correlatas. $1^{\text {a }}$ ed. São Paulo: Saraiva, 2009, p. 125.
} 
diligência de um administrador de empresas competente, não podem ser responsabilizados pelo insucesso do empreendimento ${ }^{430}$.

Principalmente o dever de diligência ganha destaque no direito comparado. $\mathrm{Na}$ Espanha, por exemplo, a lei é expressa ao determinar que todo administrador judicial deve “desempenhar seu cargo com a diligência de um administrador ordenado e de um representante leal"431 (g/n). Também neste sentido, a lei concursal portuguesa também determina, em seu artigo 56, que a culpa do administrador judicial deve ser apreciada "pela diligência de um administrador da insolvência criterioso e ordenado" utilizando os mesmos termos usados pelo Código de Sociedades Comerciais na descrição dos "deveres fundamentais" dos administradores de sociedades comerciais ${ }^{432}(\mathrm{~g} / \mathrm{n})$.

Nos Estados Unidos, não obstante o "Bankrupcty Code" não fornecer critérios específicos no que diz respeito à responsabilidade pessoal do administrador judicial, não há dúvidas no sentido de que o mesmo deve agir de acordo com os deveres fiduciários básicos por eles chamados de: i) "duty of care" (“dever de cuidado"), ou seja, o dever de não agir de forma negligente; ii) "duty of loyalty" (“dever de lealdade”), não agindo em interesse próprio; iii) "duty of obedience" ("dever de obediência"), que significa dever de não agir fora da autoridade permitida ${ }^{433}$; iv) e o "duty of impartiality" ("dever de imparcialidade"), isto é o dever de tratar todos de forma justa e igual, com imparcialidade ${ }^{434}$.

Vale anotar que segundo Osmar Brina Correa-Lima, os deveres de obediência, diligência e lealdade são adotados em decorrência da aplicação, por analogia, das normas do Código Civil que fixam as obrigações do representante e do mandatário, principalmente

\footnotetext{
${ }^{430}$ EIZIRIK, Nelson. Temas de Direito Societário. $1^{\mathrm{a}}$ ed. Rio de Janeiro: Renovar, 2005, p. 68.

431 Tradução livre de "Los administradores concursales y los auxiliares delegados desempeñarán su cargo con la diligencia de un ordenado administrador y de un representante leal." (art. 35.1., Lei 22/03).

${ }^{432}$ Art. 64, Decreto-Lei 262/86: “Art. 64 - Deveres fundamentais. 1 - Os gerentes ou administradores da sociedade devem observar: a) Deveres de cuidado, revelando a disponibilidade, a competência técnica e o conhecimento da atividade da sociedade adequados às suas funções e empregando nesse âmbito a diligência de um gestor criterioso e ordenado; e b) Deveres de lealdade, no interesse da sociedade, atendendo aos interesses de longo prazo dos sócios e ponderando os interesses dos outros sujeitos relevantes para a sustentabilidade da sociedade, tais como os seus trabalhadores, clientes e credores. 2 - Os titulares de órgãos sociais com funções de fiscalização devem observar deveres de cuidado, empregando para o efeito elevados padrões de diligencia profissional e deveres de lealdade, no interesse da sociedade."

${ }^{433}$ MCCULLOUGH, Elizabeth H. Bankruptcy Trustee Liability: is there a method in the madness? In Lewis \& Clark Law Review, Vol. 15, p. 161, 2.001.

${ }^{434}$ AMERICAN BANKRUPTCY INSTITUTE. Fiduciary Duties - during the chapter 11 case. Disponível em:

http://www.abiworld.org/committees/newsletters/young/vol7num2/The_Importance_of_Understanding_Fidu ciary Duties.pdf. p. 11-12. Acesso em 01/05/2.014.
} 
os artigos 667 a $670^{435}$. Todavia, discordamos deste entendimento na medida em que o administrador judicial não é um mero representante ou mandatário. Com base na teoria do órgão, administrador judicial não representa, mas sim "presenta" ${ }^{\text {"436 }}$. Ele manifesta sua vontade pessoal, sem deixar de obedecer, obviamente, seus deveres e atribuições ditados pela LRE.

Destarte, seja pelo teor da LRE, seja por ser auxiliar da justiça ou pelas características de suas funções, deverá o administrador judicial pautar suas atividades na obediência à lei, diligência lealdade, boa-fé, imparcialidade e independência.

\subsection{Responsabilidade.}

No momento da assinatura do termo de compromisso, o administrador judicial assume, juntamente com suas atribuições e deveres, uma série de responsabilidades pelos atos que vier ou deixar de praticar. Daí resta claro que o administrador judicial não poderá ser responsabilizado por atos e/ou omissões de administrador judicial anterior, substituído ou destituído, exceto se também continuar a praticá-los.

A atuação do administrador judicial difere na recuperação judicial e na falência; enquanto na primeira a atividade primordial do administrador judicial é a de fiscalização, na segunda assume a administração e gestão da massa falida. Consequentemente, as responsabilidades daí decorrentes são distintas.

A responsabilidade do administrador judicial é tratada pela LRE apenas no âmbito civil e penal. Recai também sobre ele a responsabilidade tributária, consoante dispositivo legal expresso do Código Tributário Nacional (CTN). A sua responsabilidade em todas as demais esferas ocorrerá quando assumir a função de gestor na recuperação judicial $^{437}$ ou prosseguir com as atividades da empresa falida ${ }^{438}$, hipóteses em que será equiparado a um verdadeiro "administrador" e, consequentemente, assim responsabilizado.

\footnotetext{
${ }^{435}$ CORRÊA-LIMA, Osmar Brina. In: CORRÊA-LIMA, Osmar Brina e LIMA, Sérgio Mourão Corrêa (coord.). Comentários à Nova lei de Falência e Recuperação de Empresas: Lei $n^{\circ}$ 11.101, de 09 de fevereiro de 2005. $1^{\mathrm{a}}$ ed. Rio de Janeiro: Forense, 2.009, p. 1.026.

${ }^{436}$ PONTES DE MIRANDA, Francisco Cavalcanti. Tratado de Direito Privado. Tomo XLIX. São Paulo: Revista dos Tribunais, 1.972, p. 113-114.

${ }^{437}$ Art. 65, LRE.

${ }^{438}$ Art. 99, inc. XI, LRE.
} 
Verificamos também, na prática forense, a inclusão do administrador judicial no polo passivo em reclamações trabalhistas, com consequentes bloqueios de bens pessoais $^{439}$. Todavia, essas decisões judiciais decorrem, na verdade, do entendimento equivocado de que o administrador judicial é o "administrador" da empresa reclamada e não pelo fato de se entender que a responsabilidade deva ser-lhe estendida. Após prestados os devidos esclarecimentos pelo administrador judicial, essas decisões têm sido integralmente reformadas ${ }^{440}$.

Vejamos, pois, as responsabilidades que recaem, via de regra, sobre o administrador judicial.

\subsubsection{Responsabilidade civil.}

Nos termos do artigo 32 da LRE, o administrador judicial, da mesma forma que os membros do comitê de credores, responde "pelos prejuízos causados à massa falida, ao devedor ou aos credores por dolo ou culpa".

Desta forma, a LRE privilegiou a responsabilidade subjetiva clássica, sendo necessária a comprovação do ato culposo ou doloso, seja por ação ou omissão, para que a respectiva indenização seja devida. Trata-se, pois, de responsabilidade aquiliana.

Paulo Fernando Campos Salles de Toledo destaca que o "legislador, nesse ponto, poderia ter ido mais longe, e estabelecido igualmente a responsabilidade das pessoas indiciadas por atos praticados com violação da lei" ${ }^{441}$, seguindo os passos da Lei $6404 / 76^{442}$. O retrocesso legal é visível, haja vista que tanto a $\mathrm{LF}^{443}$, como o Projeto de Lei

\footnotetext{
${ }^{439}$ Em decorrência da frequência das decisões judiciais neste sentido, a Corregedoria do Tribunal Regional do Trabalho da Segunda Região, emitiu a Recomendação CR n. 52/2009 para que os juízes das varas do trabalho "se abstenham de registrar, no Sistema de Acompanhamento Processual em $1^{\mathrm{a}}$ Instância - SAP 1, o nome do administrador judicial, no campo 'réu' (polo passivo da demanda), uma vez que este não é o devedor, mas sim o representante judicial da massa falida, atuando como auxiliar do juízo".

${ }^{440}$ Neste sentido, cf. Reclamação Trabalhista 002306/2005, $8^{\text {a }}$ Vara do Trabalho de Campinas, S.P.; e Reclamação Trabalhista 00107/2012, $1^{\text {a }}$ Vara do Trabalho de São Bernardo do Campo, S.P.

${ }^{441}$ TOLEDO, Paulo Fernando Campos Salles de. In TOLEDO, Paulo Fernando Campos Salles de, e ABRÃO, Carlos Henrique (coord.). Comentários à Lei de Recuperação de Empresas e Falência. $4^{a}$. ed. São Paulo: Saraiva, 2.010, p. 138.

${ }^{442}$ Art. 158, "caput”, Lei 6404/76: "O administrador não é pessoalmente responsável pelas obrigações que contrair em nome da sociedade e em virtude de ato regular de gestão; responde, porém, civilmente, pelos prejuízos que causar, quando proceder:

I - dentro de suas atribuições ou poderes, com culpa ou dolo;
} 
da Câmara dos Deputados ${ }^{444}$, previam a responsabilização do administrador judicial pela infração de dispositivo legal. Em face da redação tímida da LRE, a responsabilidade do administrador judicial somente ocorrerá quando comprovada a culpa ou o dolo - a infração à lei não gera contra ele, por si só, dever à indenização ${ }^{445}$.

Em face da adoção da responsabilidade subjetiva do administrador judicial, deverão, pois, estar presentes: i) a conduta antijurídica (omissiva ou comissiva) atribuível ao administrador judicial; ii) o dano ao lesado; iii) o nexo de causalidade entre a conduta do administrador judicial e o dano; e iv) a culpa ou dolo do administrador judicial.

Note-se que não só os atos praticados como também a falta deles poderá vir a acarretar a responsabilização do administrador judicial ${ }^{446}$. Todavia, não se pode deixar de ressaltar que muitas das obrigações do administrador judicial são obrigações de meio (como por ex., fiscalização das atividades do devedor e do plano, na recuperação; e alienação dos ativos) e não de resultado (como é o caso da prestação de contas), o que

II - com violação da lei ou do estatuto".

${ }^{443}$ Art. 68, LF: "O síndico responde pelos prejuízos que causar à massa, por sua má administração ou por infringir qualquer disposição da presente lei.

Parágrafo único. A autorização do juiz, ou o julgamento das suas contas, não isentam o síndico de responsabilidade civil e penal, quando não ignorar o prejuízo que do seu ato possa resultar para a massa ou quando infringir disposição da lei."

${ }^{444}$ Art. $70, \S 4^{\circ}$, Projeto de Lei $n^{\circ} 4.376-\mathrm{B} / 1993$ : “O administrador judicial responde pelos prejuízos que causar à recuperação judicial por culpa, dolo ou má-fé em sua administração ou por infringir qualquer disposição desta Lei".

${ }^{445}$ Francisco Cavalcante Pontes de Miranda, ao discorrer sobre a responsabilidade do síndico na LF, ensinava que: “a) Se o síndico infringe regra jurídica do Decreto-lei n. 7.661 e há dano, nasce contra ele a pretensão de indenização. Não se apura culpa, ou ciência do dano. B) Se o síndico, sem ser por infração de alguma regra jurídica do Decreto-lei n. 7.661, causa dano a alguém, como síndico, a sua responsabilidade resulta de ter conhecido o prejuízo que do seu ato - positivo ou negativo - resultaria. C) Se a responsabilidade do síndico não cabe em a), nem em b), os princípios que a regem são os de cada espécie que se componha." PONTES DE MIRANDA, Francisco Cavalcanti. Tratado de Direito Privado. Parte Especial. Tomo XXIX. Direito das Obrigações. Atualizado por Manuel Justino Bezerra Filho. São Paulo: Revista dos Tribunais, 2012, p. 102.

${ }^{446}$ Neste sentido, destacamos trecho da Ap. Cível n. 93.134, proferida pela $2^{\text {a }}$ Câmara Civil do TJSP, em julgamento datado de 19/06/59, que, não obstante tratar da LF, já ressaltava os deveres impostos ao comissário e ao síndico: “(...) Quanto ao segundo ponto, é também inquestionável que as mercadorias foram subtraídas ao controle dos credores, e do Juízo, graças à absoluta negligência dos réus, que não fiscalizaram a concordatária e lhe tornaram possível desfazer-se das mercadorias sem recolhimento do respectivo produto. Como comissários, não comunicaram o Juízo o que quer que fosse, no andamento da concordata, inclusive sobre o procedimento dos concordatários, ou às vendas que os mesmos fizeram, ou sobre os estoques, etc. Isso, aliás, resulta não apenas provado pelo comportamento dos réus na concordata, em que foram inteiramente omissos no cumprimento dos seus deveres, mas ainda confessado pelos réus reconhecendo sua negligência, de resto reconhecida por todos, inclusive pela sentença apelada. (...) Mas a culpa ficou patenteada (fls. 282/284). É evidente, aliás, que se o comissário da concordata houvesse fiscalizado os concordatários, estes não teriam distraído nem vendido gradativamente as suas mercadorias e embolsado o produto. (...) Se dolo não terá havido, a culpa grave se patenteou irrecusavelmente e nem chega a ser negado por quem quer que seja (...). De qualquer modo, se a culpa do comissário é provada, sua responsabilidade tem que ser aceita.. (...)" 
demonstra ainda mais a necessidade (e a dificuldade) de prova de que o administrador judicial não cumpriu adequadamente os seus deveres, por culpa ou dolo, e que, por isso, houve o dano. Assim, por exemplo, a falta de cumprimento do dever de fiscalização das atividades do devedor em recuperação judicial poderá (e deverá) acarretar na substituição do administrador judicial, mas este somente será responsabilizado e condenado a indenizar se for comprovado que o dano existiu e que poderia ter sido evitado caso o órgão auxiliar do juízo tivesse agido com toda diligência que o cargo lhe atribui ${ }^{447}$. Da mesma forma, a forma de alienação dos ativos escolhida por si só não acarretará na responsabilidade do administrador judicial, a qual só ocorrerá quando demonstrado que houve a lesão decorrente da culpa ou dolo do mesmo.

Tendo em vista que na recuperação judicial a regra geral é de que o administrador judicial não intervém diretamente na atuação do devedor, o qual permanece com seus plenos poderes de administração, recairá sobre este a responsabilidade por má gestão. Isto significa que a responsabilidade do administrador judicial recairá somente pelos seus atos (ou pela falta deles), descritos no tópico 3.4 supra. Todavia, ainda que a responsabilidade do administrador judicial da recuperação judicial pareça ser mais branda, ela pode ser verificada durante todo o transcrever do processo. Como já exposto, a fiscalização das atividades do devedor em recuperação judicial não deve se resumir à apresentação aos autos de meros relatórios nos quais constem somente os balancetes mensais. $\mathrm{O}$ administrador tem o dever de analisar com exatidão as receitas e despesas da empresa e verificar se o devedor não está dilapidando o seu patrimônio e apenas postergando uma inevitável falência, por exemplo. Grande responsabilidade também recai sobre o administrador judicial quando da verificação dos créditos da empresa e da condução das assembleias gerais de credores, devendo impedir a homologação de créditos eivados de simulação ou detectar eventuais fraudes que venham ocorrer quando da votação do plano de recuperação judicial, por exemplo.

Já na falência, face ao maior número de atividades desenvolvidas pelo administrador judicial, a sua responsabilidade resta mais evidenciada e, obviamente, aparece em maior escala. $\mathrm{O}$ administrador judicial é responsável pela arrecadação e guarda dos bens e documentos, bem como pela representação e gestão da massa falida até a

447 STJ, Resp. 44500-MG (1994/0005395-9), Rel. para acórdão Min. Franciulli Neto, 2a Turma, j. 28/11/2000, v.u. 
realização do ativo e o pagamento de seus credores. Deverá ele administrar a massa, maximizar o ativo e quitar a maior quantidade de dívidas possíveis, adotando todas as medidas necessárias para tais atos. Neste sentido, Pedro Pais de Vasconcelos, ao discorrer sobre a responsabilidade civil do administrador de insolvência em Portugal, ressalta que ele:

\footnotetext{
“(...) deve respeitar o interesse dos credores na recuperação de seus créditos, também o interesse do devedor em pagar a maior parte possível das suas dívidas e até mesmo a sua totalidade e não ficar insolvente, o interesse comum da conservação das empresas e até o interesse de outras empresas e outros titulares

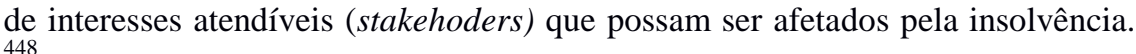

Mesmo que nosso ordenamento pátrio assim não estipule expressamente, o grau de diligência do administrador judicial (e também sua responsabilidade) deve ser compatível com as funções que ele exerce. E, por exercer atividades que demandam qualificações específicas e conhecimentos técnicos, o nível de diligência deve ser maior que ao de um "homem comum". Assim, ainda que a LRE não regule a responsabilidade do administrador judicial de uma forma mais próxima à estabelecida no CC e na LSA no tocante à responsabilidade dos administradores das sociedades, a analogia entre ambos os regimes pode ser feita face aos deveres implícitos citados no tópico 3.4.4, desde que feitas as devidas ponderações, abaixo descritas.

Eduardo Goulart Pimenta compara o regime jurídico dos administradores de sociedades empresárias, no tocante aos deveres fiduciários, com as normas do administrador judicial no que diz respeito à responsabilidade e ressalta que a "indenização alcança ilimitadamente o patrimônio do responsável, mas exige a prova de que a conduta lesiva ocorreu de modo culposo ou doloso" ${ }^{449}$. Assim, o administrador judicial, como também o administrador de sociedade, responderá por pelos prejuízos decorrentes dos atos que praticar, sem a obediência dos deveres de diligência, de obediência e lealdade, com culpa ou dolo, desde que efetivamente comprovados.

A similitude encontra-se ainda evidente nas hipóteses em que o administrador judicial figurar como gestor do devedor em recuperação judicial, ou ainda, quando ocorrer

448 VASCONCELOS, Pedro Pais de. Responsabilidade civil do administrador de insolvência. In: II Congresso de Direito da Insolvência. Serra, Catarina (coord.). Coimbra: Almedina, 2014, p. 191.

${ }^{449}$ PIMENTA, Eduardo Goulart. Atribuições e Perfil do Administrador Judicial, Gestor Judicial e Comitê de Credores no Contexto da Lei n. 11.101/05. In: CASTRO, Moema A. S. De, e CARVALHO, William Eustáquio de (coord.). Direito Falimentar Contemporâneo. $1^{\text {a }}$ Ed. Porto Alegre: Sergio Antonio Fabris, 2008, p. 27. 
a continuação provisória das atividades do falido para fins de maximização da venda dos ativos, haja vista que, nestes casos o administrador judicial efetivamente "administra" a empresa, e, portanto, deve responder como tal. Aliás, como já se expôs no tópico 3.4.3.6 supra, nesses casos o administrador judicial deverá entender do negócio da falida, atividade esta que está muito além das relacionadas no artigo 22 e demais da LRE e que poderá trazer consequências na apuração de sua responsabilidade face à falta de diligência profissional e técnica examinada no caso concreto.

Todavia, mesmo que existam semelhanças entre os deveres do administrador judicial e do administrador de sociedades empresárias, que permitem a comparação acima feita, não se pretende aqui estabelecer uma equiparação total entre eles face às diferenças existentes, que também são patentes e substanciais. As funções exercidas e os fins almejados não são os mesmos: via de regra, o administrador judicial desempenha funções próprias relacionadas e limitadas ao processo concursal e deve atuar no interesse do concurso $^{450}$; já o administrador de sociedade desempenha todas as funções necessárias decorrentes de seu objeto social, razão pela qual deve conhecer todos os pormenores da empresa, sempre visando aos interesses diretos dela e a distribuição de lucros para seus sócios $^{451}$.

A responsabilidade subjetiva do administrador judicial também é adotada no direito comparado analisado. Tendo em vista que o grau de responsabilidade varia de acordo com as funções exercidas pelo administrador judicial em cada país, e por não ser este o objeto do presente estudo, entendemos não caber aqui discuti-las. Todavia, não há como deixar de ressaltar a dificuldade existente no sentido de provar a culpa e dosar a responsabilidade do administrador judicial.

Neste sentido, merecem destaquem as discussões existentes do direito norteamericano, em decorrência do fato de o "Bankruptcy Code" determinar que o "trustee"

\footnotetext{
${ }^{450}$ GIL, Laura Zumaquero. La responsabilidad civil de los administradores concursales. Disponível em http://www.indret.com/pdf/950.pdf. Acesso em 20/05/14.

${ }^{451}$ Neste sentido, Pedro Pais de Vasconcelos destaca que mesmo nos casos de continuação da atividade da falida, o fim que orienta a gestão é a principal diferença existente: "Diversamente do que sucede com o administrador da sociedade comercial, a procura do lucro e do êxito empresarial dirige-se à satisfação do interesse do credor mas também do devedor'. VASCONCELOS, Pedro Pais de. Responsabilidade civil do administrador de insolvência. In: II Congresso de Direito da Insolvência. Serra, Catarina (coord.). Coimbra: Almedina, 2014, p. 196.
} 
"representa a massa falida" e "pode processar e ser processado" 452 sem, contudo, fornecer parâmetros para a sua responsabilidade pessoal. A referência jurisprudencial utilizada até hoje em matéria de responsabilidade do administrador judicial, por ser a única proferida pela Suprema Corte Norte americana em 1946, é o caso "Mosser x Darrow”, no qual o "trustee" foi responsabilizado por atos praticados por seus auxiliares. Nessa decisão, ficou consignado que o administrador judicial deveria ter se precavido e se isentado de responsabilidade buscando previamente orientações da corte de como deveria agir em questões de "difícil julgamento". Todavia, no que pertine à aferição da culpa, ela ensejou entendimentos dissonantes entre as cortes: i) algumas atribuem responsabilidade ao administrador judicial por mera negligencia ("mere negligence”); ii) outras conferem ao administrador um tipo de "imunidade judicial" pelos atos praticados dentro do seu âmbito de deveres, admitindo a responsabilidade apenas para medidas tomadas fora da autoridade do administrador judicial ou em violação de deveres fiduciários; iii) e, ainda, várias outras atribuíram responsabilidade ao administrador apenas nos casos de negligencia grave ("gross negligence" 453 ) ${ }^{454}$. Até hoje não há consenso entre a doutrina e/ou jurisprudência.

Consoante já exposto, a LRE concede ao administrador judicial a hipótese de contratar auxiliares (peritos, contadores, etc,) ou prepostos para assessorá-lo em suas atividades (conforme tópico 3.4.1.7).

Com relação aos prepostos e empregados, não há dúvida de que a responsabilidade do administrador judicial será objetiva, e responderá pelos atos praticados por aqueles, ainda que não haja culpa de sua parte, nos termos dos artigos 932, inciso III, e 933 do Código Civil.

\footnotetext{
452 11. U.S.C. $\S 323$ c/c 28.U.S.C $§ 959$.

${ }^{453}$ Embora não haja um consenso sobre a definição de "gross negligence", vários tribunais interpretam-na como "indiferença deliberada, devassa ou imprudente ou desrespeito deliberado de dever fiduciário do administrador ou, ainda, total falta de cuidado comprovado. Disponível em http://www.abiworld.org/AM/Template.cfm?Section=Working_Group_Proposals\&Template=/CM/ContentDi splay.cfm\&ContentID=36523. Acesso em 01/05/2014.

${ }^{454}$ Sobre as controvérsias e dificuldades existentes na aferição da responsabilidade do administrador judicial norte-americano, cf.: MCCULLOUGH, Elizabeth H. Bankruptcy Trustee Liability: is there a method in the madness? In: Lewis \& Clark Law Review, Vol. 15, p. 153-189, 2001; RADWAN, Theresa J. Pulley. Trustees in Trouble: Holding Bankruptcy Trustees Personally Liable for Professional Negligence. In: Connecticut Law Review. Vol. 35, p. 525-558, 2003; MACLACHLAN, James Angell. The title and rights of the trustee in bankruptcy. Rutgers Law Review. Vol. XIV, p. 653-677, 1960. Number 4; PRIMACK, David P. Confusion and solution: Chapter 11 bankruptcy trustee's standard of care for personal liability. In: William and Mary Law Review. Rev. 1297, Vol. 43, p.1297-1320, 2001-2002; TILLER, E. Allan. Personal Liability of Trustees and Receivers in Bankruptcy. In: American Bankruptcy Law Journal 75. Vol. 53, p. 75-103, 1979.
} 
Já os auxiliares designados diretamente pelo juízo concursal ou por ele aprovados após indicação feita nos autos pelo administrador judicial responderão diretamente pelos atos por eles praticados; a responsabilidade apenas recairá sobre o administrador judicial caso reste comprovado que este agiu com culpa ou dolo concorrente.

Verificamos no direito comparado uma sutil diferença no tratamento conferido à responsabilidade do administrador judicial por atos de seus auxiliares e que poderia ser adotada por nossa legislação pátria. De acordo com o Código de Insolvência e da Recuperação de Empresas de Portugal ${ }^{455}$ e a Lei 22/2003 ${ }^{456}$ da Espanha, o administrador judicial responde solidariamente com os seus auxiliares pelos danos causados pelos atos e omissões destes, exceto se ele provar que não houve culpa da sua parte ou que, mesmo com a diligência devida, não teriam como se evitar os danos decorrentes. A prova de inexistência de culpa ou de que o administrador judicial tomou todas as medidas cabíveis na tentativa de evitar o dano cabe, pois, a ele e não ao suposto lesado, como ocorre no direito brasileiro.

Com base no artigo 32 da LRE, Fábio Ulhoa Coelho defende que até o final do processo falimentar, somente a massa falida terá legitimidade ativa para responsabilizar o administrador judicial. $\mathrm{O}$ credor que entender ter sido lesado deverá requerer a destituição do administrador judicial (requisito este, segundo o autor, "inafastável" para "se legitimar à ação de indenização) e aguardar o fim da falência para adotar as medidas judiciais cabíveis contra aquele, eis que não seria possível "isolar o seu interesse dos da comunidade de credores" 457 .

Vera Helena de Mello Franco e Raquel Sztajn, ao tratarem da responsabilidade do administrador judicial na falência, esclarecem que a legitimidade é do novo administrador judicial, "pois cuida-se de legitimação ativa para atuar no interesse da

\footnotetext{
${ }^{455}$ Art. 59, 3, Decreto-Lei 53/2.004.

${ }^{456}$ Art. 36. 2, Lei 22/2.003.

${ }^{457}$ COELHO, Fábio Ulhoa. Comentários à Lei de Falências e de Recuperação de Empresas. $8^{\mathrm{a}}$ ed. São Paulo: Saraiva, 2011, p. 135-136.
} 
massa", razão pela qual os credores são legitimados apenas como substitutos processuais $^{458}$.

Mais acertada nos parece a posição de Sérgio Campinho, segundo o qual, em princípio, a legitimação para a propositura da ação de responsabilidade é do novo administrador judicial, tanto na recuperação judicial, como durante o processo de falência. Todavia, com base nos artigos 186 e 927 do CC, defende que qualquer credor ou mesmo o devedor, caso seja lesionado diretamente, poderá interpor a competente ação durante ou mesmo depois de findo o processo (ocasião em que a legitimação ativa caberá somente a eles ou a seus sucessores, inclusive os sócios da falida, posto que "qualquer prejuízo decorrente de má administração refletirá em seus patrimônios pessoais”,"459).

Outrossim, o julgamento das contas do administrador judicial como "boas" não o isenta de eventual e futura responsabilização, ainda que a LRE não tenha sido expressa como era a $\mathrm{LF}^{460}$ neste sentido. E a responsabilidade do administrador judicial, caso seja comprovada, ocorrerá independentemente de ter havido ou não a sua substituição ou destituição pelo juiz.

Por fim, ainda no que diz respeito à responsabilidade do administrador judicial no direito alienígena, um ponto de interesse relevante para o presente estudo é a necessidade de seguro ou caução a serem prestados pelo administrador judicial como requisito obrigatório para a sua investidura e também manutenção no cargo, como já discutido no tópico 3.2.1 supra.

Embora a LRE, seguindo as legislações concursais anteriores, não exigir, ou melhor, nem ao menos cogitar, a existência de seguro ou caução para as hipóteses da responsabilidade civil por atos do administrador judicial, a alteração na legislação neste sentido é manifestamente desejável, a fim de trazer mais segurança e credibilidade a este órgão e, consequentemente, para os institutos da recuperação judicial e da falência como um todo, inclusive em nível internacional.

\footnotetext{
${ }^{458}$ FRANCO, Vera Helena de Mello e SZTAJN, Rachel. Falência e Recuperação de Empresa em Crise. $1^{\text {a }}$ ed. Rio de Janeiro. Elsevier, 2.008, p. 69.

${ }^{459}$ CAMPINHO, Sérgio. Falência e Recuperação de Empresa: O novo regime da insolvência empresarial. $6^{\mathrm{a}}$ ed. Rio de Janeiro: Renovar, 2.012, p. 71.

${ }^{460}$ Art. 68, § único, LF.
} 


\subsubsection{Responsabilidade penal.}

O administrador judicial está arrolado como sujeito ativo no crime de violação de impedimento, descrito no artigo 177 da $\mathrm{LRE}^{461}$. Assim, praticará crime o administrador judicial que adquirir, diretamente ou através de terceiro, bens da massa falida ou da devedora em recuperação judicial, ou entrar em alguma especulação de lucro, nos processos que atuar. Trata-se, pois, de crime próprio, face à qualidade especial do sujeito ativo, e de consumação antecipada, posto bastar a mera especulação de lucro para restar configurado. O tipo se completa com a intenção, pouco importando o preço pago, o valor do bem ou o resultado da negociação ${ }^{462}$. Aliás, não é nem necessário ocorrer prejuízo à empresa em recuperação ou falida; pelo contrário, como destaca Arthur Miglari Júnior, a venda pode reverter até benefícios ao devedor ou à falida, mas o crime já estará consumado $^{463}$.

Ainda que o crime próprio do administrador judicial seja somente o previsto no artigo 177 do $\mathrm{CP}$, ele poderá ser responsabilizado criminalmente por outras condutas também tipificadas como crime na LRE.

Destarte, será também responsabilizado por crime de violação de sigilo empresarial $^{464}$, com a mesma pena acima descrita, se violar, explorar ou divulgar, sem justa causa, sigilo empresarial ou dados confidenciais sobre operações ou serviços, contribuindo para a condução do devedor a estado de inviabilidade econômica ou financeira.

O administrador judicial também poderá figurar como sujeito ativo no crime de divulgação de informações falsas ${ }^{465}$, caso divulgue ou propale informações falsas sobre o devedor em recuperação judicial, com o objetivo de levá-lo à quebra ou de obter vantagem.

\footnotetext{
462 PEREIRA, Alexandre Demetrius. Crimes falimentares - Teoria, Prática e Questões de Concursos Comentadas. $1^{\mathrm{a}}$ ed. São Paulo: Malheiros, 2.010, p. 192.

${ }^{463}$ MIGLARI JÚNIOR, ARTHUR. In: TOLEDO, Paulo Fernando Campos Salles de. In TOLEDO, Paulo Fernando Campos Salles de, e ABRÃO, Carlos Henrique (coord.). Comentários à Lei de Recuperação de Empresas e Falência. $4^{\mathrm{a}}$ ed. São Paulo: Saraiva, 2.010, p. 582.

${ }^{464}$ Art. 169, LRE.

${ }^{465}$ Art. 170, LRE.
} 
Trata-se de crime de consumação antecipada, já que não se pune o crime pela ocorrência da falência ou pela obtenção da vantagem, que são meros exaurimentos de conduta ${ }^{466}$.

Será punido pelo crime de favorecimento de credores ${ }^{467}$, o administrador judicial que favoreça um ou mais credores em prejuízo dos demais através da alienação ou oneração patrimonial de algum bem da massa falida.

Igualmente incorrerá em crime de desvio, ocultação ou apropriação de bens ${ }^{468}$, o administrador judicial que se aproprie, desvie ou oculte bens da empresa em recuperação ou da massa falida, ainda que por meio de terceiros. Note-se que este crime não se confunde com o crime próprio do artigo 177 da LRE, sendo ambos distintos e passíveis de serem cometidos de forma independente ${ }^{469}$. A rigor, o tipo penal do artigo 173 da LRE é crime comum, razão pela qual o sujeito ativo pode ser qualquer pessoa, inclusive o administrador judicial.

O crime de habilitação ilegal de crédito $^{470}$ é passível de todas as formas de concurso de agentes, envolvendo inclusive o administrador judicial, caso tenha eventualmente contribuído para a falsificação.

Todos os crimes acima relacionados têm pena de reclusão de 2 (dois) a 4 (quatro) anos, além de multa cumulativa.

Se o administrador judicial for pessoa jurídica, a responsabilidade penal recairá somente sobre o agente do delito, já que não há no direito brasileiro a responsabilidade da pessoa jurídica por crime falimentar, como ocorre na França, por exemplo ${ }^{471}$. Na hipótese de outros sócios ou administradores da pessoa jurídica terem também participado do crime, responderão como co-autores, sendo necessário, no entanto, que se evidencie a influência

\footnotetext{
${ }^{466}$ MIGLARI JÚNIOR, ARTHUR In: TOLEDO, Paulo Fernando Campos Salles de, e ABRÃO, Carlos Henrique (coord.). Comentários à Lei de Recuperação de Empresas e Falência. $4^{\mathrm{a}}$ ed. São Paulo: Saraiva, 2.010 , p. 572 .

${ }^{467}$ Art. 172, LRE.

${ }^{468}$ Art. 173, LRE.

${ }^{469}$ Em sentido contrário, cf. SILVA, JANE. In: CÔRREA-LIMA, Osmar Brina e LIMA, Sérgio Mourão Corrêa (coord.). Comentários à Nova lei de Falência e Recuperação de Empresas: Lei $n^{o} 11.101$, de 09 de fevereiro de 2005. $1^{\text {a }}$ ed. Rio de Janeiro: Forense. 2009, p. 1.153.

${ }^{470}$ Art. 175, LRE.

471 PEREIRA, Alexandre Demetrius. Crimes falimentares - Teoria, Prática e Questões de Concursos Comentadas. $1^{a}$ ed. São Paulo: Malheiros, 2.010, p. 93.
} 
na administração da sociedade e a prática do ato dela decorrente, ou qualquer outra forma de coautoria ou participação de terceiros ${ }^{472}$.

Para efeitos penais, o administrador judicial é equiparado ao devedor ou ao falido, juntamente com os sócios, diretores, gerentes, administradores e conselheiros de fato ou de direito, e responderá criminalmente na medida de sua culpabilidade, "ex vi" do disposto no artigo 179 da LRE. Destarte, a ele também se aplicam os efeitos da condenação por crime falimentar previstos no artigo 181 da LRE, que são: i) a inabilitação para o exercício da atividade empresarial; ii) o impedimento para o exercício de cargo ou função em conselho de administração, diretoria ou gerência das sociedades sujeitas à LRE; e iii) a impossibilidade de gerir empresa por mandato ou por gestão de negócio. Note-se que tais efeitos não são necessariamente cumulativos e, muito menos, automáticos, posto que devem ser motivados e declarados na sentença e perdurarão por até 5 (cinco) anos após a extinção da punibilidade, podendo cessar antes pela reabilitação penal.

Grande discussão gira em torno da equiparação ou não do administrador judicial ao funcionário público, para fins penais, por ser o administrador judicial órgão auxiliar da justiça que exerce "munus” público.

Como ensinam Celso Delmanto, Roberto Delmanto, Roberto Delmanto Júnior e Fábio Machado de Almeida Delmanto, o conceito de funcionário público, para fins penais, é distinto e mais abrangente daquele conferido pelo Direito Administrativo ${ }^{473}$. Consoante prescreve o artigo 327, “caput", do CP, é funcionário público aquele que exerce cargo, emprego ou função pública, ainda que transitoriamente ou sem remuneração. $O$ parágrafo $1^{\mathrm{o}}$ do mesmo dispositivo legal equipara a funcionário público quem trabalha em entidade paraestatal ou em empresa prestadora de serviço contratada ou conveniada para a execução de atividade típica da Administração Publica. E, finalmente, seu parágrafo $2^{\circ}$ equipara aqueles ocupantes de cargos em comissão ou de função de direção ou

\footnotetext{
${ }^{472}$ Neste sentido Alexandre Demetrius Pereira destaca que "o mero fato de uma pessoa constar como sócia em contrato social, sem poderes para exercer a gerência ou administração, não a torna legitimada para responder por delito falimentar. É necessário, portanto, que se prove a influência, de direito ou de fato, na administração e nos negócios sociais para que haja responsabilização penal por crime falimentar." PEREIRA, Alexandre Demetrius. Crimes falimentares - Teoria, Prática e Questões de Concursos Comentadas. $1^{\mathrm{a}}$ ed. São Paulo: Malheiros, 2.010, p. 90.

${ }^{473}$ DELMANTO, Celso, DELMANTO, Roberto, DELMANTO JUNIOR, Roberto, e DELMANTO, Fábio Machado de Almeida. Código Penal Comentado. $7^{\mathrm{a}}$ ed. Rio de Janeiro: Renovar, 2007, p. 811.
} 
assessoramento de órgão da administração direta, sociedade de economia mista, empresa pública ou fundação instituída pelo Poder Público, aumentando em um terço a sua pena.

Segundo Trajano de Miranda Valverde, o administrador judicial, embora exerça as funções de um cargo criado pela lei especialmente para ele, "não é, no regime da legislação brasileira, funcionário público, embora seja a este equiparado, para os efeitos penais" ${ }^{474}$. Este também é o entendimento de Rubens Requião e Fábio Ulhoa Coelho ${ }^{475}$.

Ousamos discordar porque como já discutido no tópico 3.1 supra, o administrador judicial não exerce cargo ou função pública, mas tão somente exerce um "munus" público; e o fato de exercer "munus" público "não transforma quem o exerce em funcionário púbico para os efeitos penais" ${ }^{476}$, sendo, pois, impossível a sua equiparação nos termos dos parágrafos $1^{\circ}$ e $2^{\circ}$ do supra referido dispositivo legal.

Neste sentido, Nelson Hungria ressalta que é preciso "não confundir função pública com múnus público. Assim, não são exercentes de função pública os tutores ou curadores dativos, os inventariantes judiciais, os síndicos falimentares (estes últimos estão sujeitos à lei pena especial), etc" ${ }^{477}$.

Este também é o entendimento de Magalhães Noronha, que, ao tratar no LF, asseverou ter o Decreto-lei 7661/45 disciplinado as funções do síndico, sujeitando-o a sanções de ordem penal, inclusive, "sem, no entanto, equipará-lo ao funcionário público, ou conferir-lhe função pública" ${ }^{478}$. Também neste sentido, confira-se Celso Delmanto et alli $^{479}$ e Rui Stoco e Tatiana de Oliveira Stoco $^{480}{ }_{-}^{481}$.

\footnotetext{
${ }^{474}$ VALVERDE, Trajano de Miranda. Comentários à Lei das Falências. (Decreto-lei $n^{\circ} 7.661$, de 21 de junho de 1945). Vol. II (art. 62 a 176). $4^{\text {a }}$ ed. rev. e atualizada por J. A. Penalva Santos e Paulo Penalva Santos. Rio de Janeiro: Revista Forense, 1.999, p. 98.

${ }^{475}$ REQUIÃO, Rubens. Curso de direito falimentar. Falência. $1^{\circ}$ Vol. $6^{a}$ ed. São Paulo: Saraiva, 1981, p. 213; e COELHO, Fábio Ulhoa. Comentários à Lei de Falências e de Recuperação de Empresas. $8^{a}$ ed. São Paulo: Saraiva, 2011, p. 109.

${ }^{476}$ COGAN, ARTHUR. Crimes contra a administração pública. São Paulo: Juarez de Oliveira, 2.003, p. 106.

${ }^{477}$ HUNGRIA, Nelson. Comentários ao Código Penal. Vol IX, $4^{\mathrm{a}}$ ed. Rio de Janeiro: Forense, 1.958, p. 400.

${ }^{478}$ NORONHA, Edgar Magalhães. Direito Penal. Vol. IV, $8^{\text {a }}$ ed. São Paulo: Saraiva, 1.972, p 226.

${ }^{479}$ DELMANTO, Celso, DELMANTO, Roberto, DELMANTO JUNIOR, Roberto, e DELMANTO, Fábio Machado de Almeida. Código Penal Comentado. $7^{\mathrm{a}}$ ed. Rio de Janeiro: Renovar, 2007, p. 813.

${ }^{480}$ STOCO, Rui e TATIANA de O Stoco. FRANCO, Alberto Silva e STOCO, Rui (coord.). Código Penal e sua interpretação: doutrina e jurisprudência. $8^{\mathrm{a}}$ ed. São Paulo: Revista dos Tribunais, 2.007, p. 1526.
} 
Outra discussão existente, no tocante a responsabilidade penal do administrador judicial, diz respeito ao comando previsto no artigo 23 da LRE. Segundo este dispositivo legal, o administrador judicial que não apresentar, no prazo estabelecido, suas contas ou os relatórios previstos na LRE, será intimado pessoalmente para assim fazer no prazo de 5 (cinco) dias, sob pena de ser responsabilizado por desobediência.

Luis Inácio Vigil Neto discute se tal descumprimento configuraria crime de desobediência, nos termos do artigo 330 do $\mathrm{CP}^{482}$, concluindo pela possibilidade de enquadramento em face da presença de seus elementos de adequação (ordem legal, autoridade legítima e não-obediência) ${ }^{483}$. Em entendimento oposto, Paulo Fernando Campos Salles de Toledo defende que, ao permanecer omisso, o administrador judicial estaria descumprindo um dever funcional e não uma ordem judicial, passível de incorrer, portanto, em crime de prevaricação, caso o agente tenha assim agido para "satisfazer interesse ou sentimento pessoal", nos termos do artigo $319, \mathrm{CP}^{484}{ }_{-}^{485}$.

Justamente por todo o exposto acima no sentido de que o administrador judicial não pode ser equiparado a funcionário público para fins penais, entendemos que ele não pode ser sujeito ativo de crime de prevaricação ${ }^{486}$. Ademais, inicialmente o administrador judicial estará descumprindo um dever; todavia, após intimado, o descumprimento será de ordem judicial. O crime imputável, portanto, será o de desobediência, conforme previsto na LRE, por ser praticado por particular por desobediência à ordem judicial ${ }^{487} \_488$.

\footnotetext{
${ }^{481}$ Este também tem sentido o entendimento da jurisprudência: TJSP, HC 21.804-3-SP, Rel. Carmo Pinto, Câmara de Férias, j. 28/07/83, v.u.). In: Revista de Jurisprudência do Tribunal de Justiça do Estado de São Paulo, vol. 85, São Paulo: Lex Editora, 1983, p. 388-395.

${ }^{482}$ Art. 330, CP: "Desobedecer a ordem legal de funcionário público:

Pena - detenção, de quinze dias a seis meses, e multa."

483 VIGIL NETO, Luiz Inácio. Teoria Falimentar e Regimes Recuperatórios: Estudos sobre a Lei 11.101/2005. Porto Alegre: Livraria do Advogado, 2.008, p. 106-107.

484 TOLEDO, Paulo Fernando Campos Salles de. In: TOLEDO, Paulo Fernando Campos Salles de, e ABRÃO, Carlos Henrique (coord.). Comentários à Lei de Recuperação de Empresas e Falência. 4a. ed. São Paulo: Saraiva, 2.010, p. 118.

${ }^{485}$ Art. 319, CP: "Retardar ou deixar de praticar, indevidamente, ato de ofício, ou praticá-lo contra disposição expressa de lei, para satisfazer interesse ou sentimento pessoal:

Pena - detenção, de três meses a um ano, e multa."

486 Neste sentido, verifique-se: TJSP, Revisão Criminal n. 124.087, Rel. Acácio Rebouças, Câmaras Conjuntas Criminais, j. 04/03/75. In: Revista de Jurisprudência do Tribunal de Justiça do Estado de São Paulo, vol. 33, São Paulo: Lex Editora, 1975, p. 307-309.

${ }^{487}$ VERÇOSA, Haroldo Malheiros Duclerc. In SOUZA JUNIOR, Francisco Satiro de, e PITOMBO, Antônio Sérgio de A. Moraes. (coord.). Comentários à Lei de Recuperação de Empresas e Falência. Lei 11.101/2005. - Artigo por Artigo. $2^{\mathrm{a}}$ ed. São Paulo: Revista dos Tribunais, 2007, p. 177.

${ }^{488}$ Note-se que a definição sobre o crime praticado não encerra outra discussão jurisprudencial, no sentido de que havendo cominação de sanção civil (no caso a destituição do administrador judicial) para a hipótese de
} 


\subsubsection{Responsabilidade tributária.}

Embora a LRE nada disponha sobre outra responsabilidade do administrador judicial que não seja no âmbito civil e penal, de grande valia é a análise de sua responsabilidade tributária, tanto por haver disposição expressa no Código Tributário Nacional (CTN), como pelas recorrentes decisões judiciais e seus respectivos recursos sobre esta matéria.

Nos termos do artigo 121 do CTN, o sujeito passivo da obrigação principal é a pessoa obrigada a pagar o tributo ou a penalidade pecuniária de caráter moratório, englobando tanto o contribuinte - sujeito passivo direto, que tem relação pessoal e direta com o fato gerador, como o responsável - sujeito passivo indireto, cuja obrigação decorre de disposição expressa de lei.

A responsabilidade tributária pode ser, portanto, originária - quando recai sobre o contribuinte, ou derivada - que tem como foco pessoa estranha ao fato gerador, por determinação legal $^{489}$.

Podemos definir a responsabilidade tributária derivada como a imposição legal da obrigação tributária atribuída a um terceiro (pessoa física ou jurídica), o qual, não obstante não ser o contribuinte, vincula-se ao fato gerador assumindo com ele ou o substituindo a responsabilidade pelo pagamento do tributo ou penalidade pecuniária ${ }^{490} \mathrm{Na}$ primeira hipótese temos a responsabilidade solidária subsidiária, posto que o responsável somente responderá "na impossibilidade de exigência do cumprimento da obrigação principal pelo contribuinte", nos termos do artigo 134 do CTN. No segundo caso, a responsabilidade é transferida a um terceiro por sucessão ou por ato que resulte de excesso de poder ou infrações legais, contratuais ou estatutárias (artigo 135, CTN).

descumprimento da ordem judicial e não prevendo a lei extrapenal cumulação com o art. 330 do $\mathrm{CP}$, inexiste crime de desobediência. TJRS, RC 71004136214-RS, Turma Recursal Criminal, Rel. Des. Cristina Pereira Gonzales, j. 25/02/2.013

${ }^{489}$ DENARI, Zelmo. Sujeitos Ativo e Passivo da Relação Jurídica Tributária. In: MARTINS, Ives Gandra da Silva (coord.). Curso de Direito Tributário. $7^{\mathrm{a}}$ ed. São Paulo: Saraiva, 2.000, p. 161-180.

490 OLIVEIRA, Fábio Leopoldo. Responsabilidade Tributária. In: MARTINS, Ives Gandra da Silva (coord.). Idem, p. 197-222. 
A sucessão tributária pode ser: i) imobiliária ou patrimonial (artigos 130 e 131, inciso I, CTN); ii) comercial ou empresarial (artigos 132 e 133, CTN); iii) "causa mortis" (artigo 131, incisos II e III, CTN); e iv) falimentar (artigo 184, $\mathrm{CTN}^{491}$ ).

Assim, nos termos do art. 184 do CTN, a massa falida é sucessora tributária e responde pelo pagamento do crédito tributário existente, com a totalidade de seus bens e rendas. No entanto, o que verificamos, na prática, é a insistência de inúmeros representantes do Fisco em responsabilizar os administradores judiciais pela simples falta de pagamento dos tributos (na maioria das vezes anteriores à quebra, já que, com a decretação da falência, a regra é a paralisação completa das atividades do devedor) ou pela falta de impugnação a autos de infração ${ }^{492}$, por exemplo, com pedido de bloqueio de seus bens pessoais, principalmente nas hipóteses de falência ${ }^{493}$.

Todavia, o enquadramento do administrador judicial como responsável tributário deve ser visto com cautela e atenção. Vejamos.

\footnotetext{
${ }^{491}$ Art. 184, CTN: "Sem prejuízo dos privilégios especiais sobre determinados bens, que sejam previstos em lei, responde pelo pagamento do crédito tributário a totalidade dos bens e das rendas, de qualquer origem ou natureza, do sujeito passivo, seu espólio ou sua massa falida, inclusive os gravados por ônus real ou cláusula de inalienabilidade ou impenhorabilidade, seja qual for a data da constituição do ônus ou da cláusula, excetuados unicamente os bens e rendas que a lei declare absolutamente impenhoráveis."

${ }^{492}$ Neste sentido, cf STJ, Resp no 493.316 - DF (2002/0156684-4), Rel. Min. José Delgado, $1^{\text {a }}$ Turma, j. 08/04/2003: "EMENTA: TRIBUTÁRIO E ADMINISTRATIVO. RESPONSABILIDADE. LIMITES. ARTS. 134, V, E 135, I, DO CTN, 68 E 69, DO DL No 7.661/45. INSCRIÇÃO DE SÍNDICO DE MASSA FALIDA EM DÍVIDA ATIVA COMO CO-RESPONSÁVEL SOLIDÁRIO PELOS DÉBITOS TRIBUTÁRIOS DA MASSA. PERÍODO ANTERIOR À DECRETAÇÃO DA FALÊNCIA. IMPEDIMENTO DE REGULARIZAÇÃO DE ESCRITÓRIO PROFISSIONAL. ILEGALIDADE E ABUSIVIDADE. ART. 170, PARÁGRAFO ÚNICO, DA CARTA MAGNA. IMPRESTABILIDADE DE MEIOS COERCITIVOS. SÚMULAS N $\mathrm{N}^{\circ} \mathrm{S}$ 70, 323 E 547/STF. APLICAÇÃO ANALÓGICA. (...) 3. A responsabilidade pessoal e solidária pode ser imputada ao síndico de massa falida em relação aos atos em que intervier ou pelas omissões de que é responsável (art. 134, V, do CTN), assim como em relação aos créditos correspondentes a obrigações tributárias resultantes de atos por ele praticados com excesso de poderes ou infração de lei (art. 135, I, do CTN). 4. Não configura hipótese de responsabilidade pessoal e solidária o fato de o síndico ter sido cientificado da lavratura de auto de infração contra a massa falida e deixar de apresentar impugnação. É, portanto, totalmente ilegal e abusiva a condição mais enérgica criada pela autoridade fiscal de impedir a regularização de escritório profissional, com o intuito de cobrar os créditos da Fazenda Pública. 5. A prescrição do art. 68, da Lei de Falências (DL n ${ }^{\circ}$ 7.661/54), chama o síndico à responsabilidade somente "pelos prejuízos que causar à massa, por sua má administração ou por infringir qualquer disposição da presente lei". Essa responsabilidade, no entanto, somente pode ser imputada pelo Juízo da Falência após a prestação de contas prevista no art. 69 , da referida Lei. 6 . A solidariedade do sócio pela dívida da sociedade só se manifesta, todavia, quando comprovado que, no exercício de sua administração, praticou os atos elencados na forma do art. 135, caput, do CTN. Há impossibilidade, pois, de se cogitar na atribuição de tal responsabilidade substitutiva quando sequer estava o síndico investido das funções diretivas da sociedade. 7. Recurso não provido."

${ }^{493}$ KUGELMAS, Alfredo Luiz, e ARRUDA PINTO, Gustavo Henrique Sader de. Administrador judicial na recuperação judicial: Aspectos Práticos. In: DELUCCA, Newton de, e DOMINGUES, Alessandra de Azevedo (coord.). Direito Recuperacional. Aspectos teóricos e práticos. 1ª ed. São Paulo: Quartier Latin, 2.009 , p. 225.
} 
Em primeiro lugar, cumpre lembrar que a responsabilidade tributária, como todas as outras responsabilidades, somente pode ser imposta eventualmente ao administrador judicial para os fatos geradores ocorridos a partir de sua investidura no cargo.

Feito tal esclarecimento, a responsabilidade tributária do administrador judicial apresenta-se, via de regra, como solidária (na hipótese prevista no artigo 134, incisos V, $\mathrm{CTN}^{494}$ ) e, excepcionalmente, como de caráter pessoal (“ex vi” do disposto no artigo 135 , inciso $\left.\mathrm{I}^{495}\right)$.

A responsabilidade prevista no artigo 135, inciso I, do CTN decorre de atos praticamente diretamente pelo administrador judicial com excesso ou abuso de poder $^{496}$. Como nas demais áreas do direito, não resta nenhuma dúvida acerca da responsabilidade pessoal e direta do administrador judicial quando este pratique atos que sejam ilegais. Nestes casos, ele responderá com seu patrimônio pessoal e de forma ilimitada.

Já a responsabilidade solidária do administrador judicial, constante do artigo 134, inciso V, do CTN , deve ser interpretada “cum granu salis”. Primeiro porque a massa falida já é a responsável tributária por sucessão (artigo 184, CTN). Segundo porque a responsabilidade do administrador judicial, prevista no artigo 134 pressupõe as seguintes condições: i) que a massa falida não possa cumprir sua obrigação; e ii) que o administrador judicial seja responsável pelo ato que configure o fato gerador do tributo ou em relação a este tenha indevidamente se omitido, e, em decorrência deste ato (ou omissão) seja impossível exigir-se o cumprimento da obrigação tributária pela massa falida. É necessário, pois, "que exista uma relação entre a obrigação tributária e o comportamento daquele a

\footnotetext{
${ }^{494}$ Art. 134, CTN: "Nos casos de impossibilidade de exigência do cumprimento da obrigação principal pelo contribuinte, respondem solidariamente com este nos atos em que intervierem ou pelas omissões de que forem responsáveis:

$(\ldots)$

V - o síndico e o comissário, pelos tributos devidos pela massa falida ou pelo concordatário;

$(\ldots)$.

${ }^{495}$ Art. 135, CTN: São pessoalmente responsáveis pelos créditos correspondentes a obrigações tributárias resultantes de atos praticados com excesso de poderes ou infração de lei, contrato social ou estatutos:

$\mathrm{I}$ - as pessoas referidas no artigo anterior"

${ }^{496}$ Este também tem sido o entendimento da jurisprudência: STJ, Resp. 493.316-DF, Rel. Min. José Delgado, Primeira Turma, j. 02/06/03, v.u.; TRF-4a Região, Ap. Civ. n. 2000.72.00.008795-1/SC, Rel. Juíza Federal Vânia Hack De Almeida, 2a Turma, j. 20/04.10, v.u.
} 
quem a lei atribui a responsabilidade" 497 . Desta forma, exceto se estiverem presentes tais pressupostos, o administrador judicial não será responsável solidário com a massa falida, consoante a conclusão de Luis Eduardo Schoueri:

\begin{abstract}
Ou seja: não se há de entender o dispositivo acima no sentido de tornar as pessoas arroladas responsáveis por qualquer tributo devido; é necessário que uma ação ou omissão dessas pessoas tenha o efeito de gerar a impossibilidade de exigência do cumprimento da obrigação principal pelo sujeito passivo originário. Este aspecto torna-se evidente quando se toma o caso do síndico da massa falida: é corriqueiro que esta não possa solver seus débitos, inclusive tributários. Nem por isso, será o síndico responsável pelos tributos. Entretanto, se por causa de seu ato ou omissão, o débito tributário deixa de ser pago, aí então se torna ele responsável. ${ }^{498}$
\end{abstract}

Mister lembrar que na hipótese de aplicação do artigo 134, inciso V, do CTN, o administrador judicial responderá apenas pelo tributo ou pela penalidade de cunho moratório (“ex vi” do parágrafo único do referido dispositivo legal), ao contrário do que ocorre com a situação prevista no artigo 135 do mesmo diploma legal, ocasião em que ele será responsável também pela penalidade pecuniária ${ }^{499}$.

Tendo em vista que o administrador judicial não pratica atos de gestão do devedor em recuperação judicial, muito difícil se vislumbrar sua responsabilidade nos casos de recuperação judicial, já que apenas responderá ao Fisco em decorrência de atos que tenha praticado ou por suas omissões e a fiscalização das atividades do devedor e do plano de recuperação judicial não abrange o controle efetivo do pagamento de tributos. A exceção ocorre justamente quando o administrador judicial assume a gestão nos termos do artigo 65, parágrafo $1^{\circ}$ da LRE, ocasião em que será enquadrado como responsável tributário em razão de todos os atos (ou omissões) por ele praticados.

As hipóteses de responsabilidade do administrador judicial na esfera tributária aparecem com mais frequência na falência. Todavia, a decretação da falência da empresa por si só, não gera a responsabilidade do administrador judicial pelos tributos e encargos moratórios. Como acima exposto, a massa falida é sucessora tributária e assim responderá com seu patrimônio, durante o processo de liquidação ${ }^{500}$; o administrador judicial

\footnotetext{
${ }^{497}$ MACHADO, Hugo de Brito. Curso de Direito Tributário. 28 a ed. São Paulo: Malheiros, 2.007, p. 185.

${ }^{498}$ SCHOUERI, Luis Eduardo. Direito Tributário. São Paulo: Saraiva, 2.011, p. 507.

${ }^{499}$ SCHOUERI, Luis Eduardo. Idem, p. 517.

${ }^{500}$ Sobre a tributação da massa falida, cf. CAMILO JÚNIOR, Ruy Pereira. Empresa em Crise e Tributação. In: TOLEDO, Paulo Fernando Campos Salles de; e SOUZA JUNIOR, Francisco Satiro de (coords.). Direito das Empresas em Crise: Problemas e Soluções. $1^{\text {a }}$ ed. São Paulo: Quartier Latin, 2012, p. 297-342.
} 
responderá única e exclusivamente se presentes as condições acima apontadas. Já na hipótese de manutenção das atividades negociais da falida (artigo 99, XI, LRE) o administrador judicial responderá de forma pessoal por seus atos e omissões, como também ocorre com o gestor judicial na recuperação judicial, da mesma maneira que respondem os administradores das sociedades empresárias em geral.

A pretensão de ampliar essas hipóteses de responsabilidade, como bem ressaltado por Ruy Pereira Camilo Júnior, "têm o efeito de afastar do exercício desse mister pessoas dignas e probas, que não aceitarão assumir riscos por atos que deles não dependam". 501

\subsection{Hipóteses de substituição e destituição.}

O administrador judicial não é detentor de nenhum direito subjetivo para permanência no cargo ${ }^{502}$, razão pela qual poderá ser substituído a qualquer tempo, desde que haja a perda de confiança do juiz ou se verifique alguma das situações previstas no artigo 30 da LRE, ou destituído em decorrência das hipóteses constantes do artigo 31 da LRE.

Substituição e destituição são hipóteses que não se confundem e trazem consigo consequências totalmente diversas.

No caso de a nomeação ocorrer em desacordo com a determinação legal conforme impedimentos previstos no artigo 30 da LRE e discorridos no tópico 3.3 supra, o devedor, qualquer interessado ou o Ministério Público poderá requerer ao juiz a substituição do administrador judicial ou dos membros do Comitê. Além das hipóteses de impedimentos previstas no artigo 30, o administrador judicial também será substituído quando houver: i) renúncia fundamentada ${ }^{503}$; ii) sua morte ou interdição; iii) sua falência,

\footnotetext{
${ }^{501}$ CAMILO JÚNIOR, Ruy Pereira. Empresa em Crise e Tributação. In: TOLEDO, Paulo Fernando Campos Salles de; e SOUZA JUNIOR, Francisco Satiro de (coords.). Direito das Empresas em Crise: Problemas e Soluções. $1^{a}$ ed. São Paulo: Quartier Latin, 2012., p. 329.

${ }^{502}$ TJSP, AI n. 239.281-1/3, Rel. Des. Flávio Ribeiro, $3^{\text {a }}$ Câmara Civil, j. 27.12.94. In Revista dos Tribunais, vol. 715 , p. $142 / 143$.

${ }^{503}$ Art. 22 , inc. III, al. "r" c/c art. $22, \S 3^{\circ}$, LRE
} 
recuperação judicial ou dissolução, face à falta de idoneidade financeira; e iv) perda de confiança do juízo.

Nos termos da legislação anterior ${ }^{504}$, a "reclamação" quanto à nomeação do administrador judicial somente poderia ser feita dentro do prazo de quarenta e oito horas após a publicação do aviso inicial aos credores feito pelo sindico. Já pela atual LRE, o requerimento de substituição poderá ocorrer a qualquer momento, durante todo o transcorrer da recuperação judicial ou da falência.

Ao juiz é dado decidir sobre esse requerimento no prazo de 24 horas ${ }^{505}$. Este prazo, como salienta Paulo Fernando Campos Salles de Toledo, será contado "a partir do momento em que a questão estiver pronta para ser decidida", após a oitiva do administrador e do Ministério Público, caso o pedido tenha sido feito por um credor e/ou terceiro $^{506}$.

Verificamos, assim, que a substituição do administrador judicial não se reveste de caráter sancionatório; ela decorre do desejo do próprio administrador judicial ou de circunstancias alheias a sua vontade, mas desprovidas de culpa ou dolo do mesmo ${ }^{507}$.

Já a destituição é sanção imposta ao administrador judicial em decorrência da desobediência dos deveres e obrigações que lhe são atribuídos no momento da investidura no cargo. As hipóteses expressas na lei são: i) a falta de apresentação das contas e relatórios dentro dos prazos previstos em $\mathrm{LRE}^{508}$; ii) a desobediência aos preceitos

\footnotetext{
${ }^{504}$ Art. 60, LF:

" (...)

$4^{\circ}$ Até quarenta e oito horas após a publicação do aviso referido no art. $63, \mathrm{n}^{\circ} 1$, qualquer interessado pode reclamar contra a nomeação do síndico em desobediência a esta lei. $\mathrm{O}$ juiz, atendendo às alegações e provas, decidirá dentro de vinte e quatro horas, e do despacho cabe agravo de instrumento.

(...)"

${ }^{505}$ Art. $30, \S \S 2^{\circ}$ e $3^{\circ}$, LRE.

506 TOLEDO, Paulo Fernando Campos Salles de, In: TOLEDO, Paulo Fernando Campos Salles de, e ABRÃO, Carlos Henrique (coord.). Comentários à Lei de Recuperação de Empresas e Falência, $4^{\mathrm{a}}$ ed. São Paulo: Saraiva, 2.010, p. 136.

${ }^{507}$ NEGRÃO, Ricardo. Aspectos Objetivos da Lei de Recuperação de Empresas e de Falências: Lei 11.101, de 9 de fevereiro de 2005. $1^{\text {a }}$ ed. São Paulo: Saraiva, 2.005, p. 103.

${ }^{508}$ Art. 23, § único, LRE.
} 
legais ${ }^{509}$; e iii) a omissão, a negligência, o dolo, ou a pratica de ato lesivo às atividades do devedor ou de terceiros ${ }^{510}$.

A LRE não prevê expressamente, como fazia a LF no "caput" do seu artigo 66, a destituição do síndico que tivesse interesses contrários à massa. Todavia, entendemos ser necessária a destituição do administrador judicial nesses casos, posto que ele estará descumprindo os preceitos previstos na LRE e incorrendo em falta grave, já que não exercerá seu papel com a idoneidade e a imparcialidade necessárias.

Não é demais lembrar que em face da gravidade das sanções aplicadas ao administrador judicial, a destituição deverá tão somente ocorrer quando houver prova concreta de qualquer uma das hipóteses previstas em lei ${ }^{511}{ }^{512}$.

A substituição e a destituição podem dar-se de oficio ou a requerimento fundamentado de qualquer interessado. Na mesma decisão que determinar a destituição, o juiz nomeará novo administrador judicial ${ }^{513}$.

O pedido de substituição ou destituição pode ser feito por simples petição ${ }^{514}$ nos autos da recuperação judicial ou da falência, desde que fundamentada e carreada com provas do alegado, nos termos do artigo 333 do Código de Processo Civil. Todavia,

${ }^{509}$ Art. 31, "caput", LRE.

${ }^{510}$ Art. $24, \S 3^{\circ} \mathrm{c} / \mathrm{c}$ art. 31, “caput", LRE.

511 "EMENTA: DIREITO PROCESSUAL CIVIL. FALÊNCIA. DESTITUIÇÃO DE ADMINISTRADOR JUDICIAL. SANÇÃO GRAVE. PONDERAÇÃO DO CASO CONCRETO. MANUTENÇÃO DO ADMINISTRADOR. HOMOLOGAÇÃO DA AVALIAÇÃO DE IMÓVEL. CONTRADITÓRIO. AUSÊNCIA. NECESSIDADE. PARCIAL PROVIMENTO. 1. A desobediência aos preceitos da Lei 11.101/2005, o descumprimento de dever, omissão, negligência ou a prática de ato lesivo à atividade do devedor ou a terceiros por parte do administrador judicial que ensejam a sua destituição (art. 31) devem ser tão graves quanto à sanção imposta, que leva a perda do direito à remuneração e o impedimento de ser nomeado durante os próximos cinco anos para atividade semelhante, não se caracterizando quando o próprio falido não fornece nos autos os elementos necessários para a escorreita atuação do auxiliar do juízo. 2. Em respeito ao contraditório é indispensável a prévia concessão de oportunidade para manifestação de ambas as partes e interessados antes das homologação da avaliação de determinado bem a ser levado a leilão. 3 . Agravo de Instrumento a que se dá parcial provimento." TJPR - AI: 6781959 PR 0678195-9, Relator: Francisco Jorge, $17^{\mathrm{a}}$ Câmara Cível, j. 30/03/2011. (g/n).

${ }_{512}$ No mesmo sentido: TJSP, AI n. 0225852-62.2011.8.26.0000, Câmara Especial de Falências e Recuperações Judiciais, Des. Rel. Elliot Akel, j. 28.02.2012; e TJSP, AI n. 486.728.4/2, Rel. Des. José Roberto Lino Machado, Câmara Especial de Falências e Recuperações Judiciais, j. 01/08/07, v.u.

${ }^{513}$ Art. 31, LRE.

514 "EMENTA: Agravo de instrumento - Falência - Pedido de destituição ou substituição do administrador judicial. Não se configurando, no caso concreto, as hipóteses legais para destituição do administrador judicial, deve ele ser mantido no cargo, no qual está sob a confiança do juízo da falência e para o qual está profissionalmente habilitado. Agravo improvido.”. TJSP, AI n. 486.728.4/2, Rel. Des. José Roberto Lino Machado, Câmara Especial de Falências e Recuperações Judiciais, j. 01/08/07, v.u. 
verificamos a existência de recebimento de petição como incidente de destituição ${ }^{515}$, ou exceção de suspeição, por analogia, com base nos artigos $135^{516}$ (o administrador judicial, por ser auxiliar do Juízo, se submeteria aos mesmos impedimentos e suspeições do magistrado ${ }^{517}$ ) e 138 (o administrador judicial se submeteria aos mesmos impedimentos e suspeições dos promotores de Justiça, peritos e serventuários de Justiça), ambos do Código de Processo Civil.

Apesar de a LRE não prever a oitiva do administrador judicial, é necessária a concessão de prazo para sua defesa, em garantia ao princípio constitucional do contraditório e da ampla defesa, para os casos de destituição ${ }^{518}$. Já nas hipóteses de substituição, o administrador judicial poderá ser removido "ad nutum", haja vista que geralmente decorre da falta de confiança do juiz ou de nomeação feita de forma contrária às disposições legais.

A decisão judicial, em favor ou em entendimento contrário à destituição ou substituição, será passível de reforma mediante a interposição de recurso de agravo. E, na hipótese de provimento de recurso eventualmente interposto pelo administrador judicial, verificam-se duas soluções possíveis, embora não previstas na LRE: i) a recondução ao cargo ou ii) o recebimento de indenização pelos prejuízos sofridos, nos termos do artigo 186 do Código Civil ${ }^{519}$. Note-se que, segundo esclarece Haroldo Malheiros Duclerc Verçosa, qualquer uma das duas soluções poder trazer problemas na prática: i) caso haja a recondução ao cargo, a celeridade do processo poderá vir a ser afetada, posto que acarretará em nova mudança na administração, “com prejuízo parar a continuidade do trabalho que vinha sendo exercido pelo substituto"; ii) e a indenização, "que melhor atenderia aos interesses gerais em jogo" pode apresentar "problema da incapacidade de

\footnotetext{
${ }^{515}$ TJSP, AI n ${ }^{\circ}$ 0090909-74.2012.8.26.0000, Rel. Araldo Telles, $2^{\text {a }}$ Câmara Reservada de Direito Empresarial, j. $6 / 11 / 12$, v.u.

${ }^{516}$ TJSP, AI n ${ }^{\circ}$ 630.514.4/0-00, Rel. Ribeiro da Silva, $8^{\text {a }}$ Câmara de Direito Privado, j. 10/02/10, v.u.

517 “(...) O administrador judicial é um auxiliar do Juízo. Logo, ele está submetido aos impedimentos e suspeições do Magistrado, nos termos do artigo 138, do Código de Processo Civil e por essa razão faço algumas transcrições de decisões onde se demonstra que alegações infundadas não merecem credibilidade." (excerto de sentença proferida nos autos do processo 2008.0503.8366, Juiz Hamilton Gomes Carneiro, $4^{\mathrm{a}}$ Vara Cível de Anápolis-GO, j. 29/11/12.).

${ }^{518}$ Art. $5^{\circ}$, inc. LV, Constituição Federal da República de 1.988.

${ }^{519}$ VERÇOSA, Haroldo Malheiros Duclerc. In: SOUZA JUNIOR, Francisco Satiro de, e PITOMBO, Antônio Sérgio de A. Moraes. (coord.). Comentários à Lei de Recuperação de Empresas e Falência. Lei 11.101/2005. - Artigo por Artigo. $2^{\mathrm{a}}$ ed. São Paulo: Revista dos Tribunais, 2.007, p. 184.
} 
pagamento" por quem deu causa ${ }^{520}$.

A substituição e a destituição geram efeitos distintos na remuneração do administrador judicial. Nas situações em que o administrador judicial é substituído, sua remuneração será proporcional ao trabalho realizado, exceto se a substituição decorreu de renúncia imotivada ${ }^{521}{ }_{-}^{522}$. Já na destituição, além de ficar impedido de atuar em outra recuperação judicial ou falência pelo prazo de cinco anos, o até então administrador judicial perderá o direito de remuneração ${ }^{523}$.

\subsection{Critérios de remuneração.}

$\mathrm{O}$ administrador judicial não exerce a sua função de modo gratuito. $\mathrm{O}$ valor de sua remuneração é fixado pelo juiz, de acordo com a capacidade de pagamento do devedor, o grau de complexidade dos trabalhos e os valores praticados no mercado para o desempenho de atividades semelhantes ${ }^{524}$.

A LRE não determina o valor mínimo de pagamento e nem apresenta tabelas progressivas como as utilizadas em diversos países ${ }^{525}$; apenas estipula o teto da

520 VERÇOSA, Haroldo Malheiros Duclerc. In: SOUZA JUNIOR, Francisco Satiro de, e PITOMBO, Antônio Sérgio de A. Moraes. (coord.). Comentários à Lei de Recuperação de Empresas e Falência. Lei 11.101/2005. - Artigo por Artigo. 2a ed. São Paulo: Revista dos Tribunais, 2.007, p. 184.

${ }^{521}$ Art. $24, \S 3^{\circ}$, LRE.

${ }^{522}$ Paulo Fernando Campos Salles de Toledo ressalta ser correta a sanção prevista para as hipóteses de substituição por renuncia sem relevante razão: “A função do administrador judicial constitui múnus público importante, de modo que sua renuncia imotivada, após haver aceito o encargo e se comprometido a bem exercer os deveres a ele relativos, representa desrespeito à Justiça e à coletividade de credores. TOLEDO, Paulo Fernando Campos Salles de, In: TOLEDO, Paulo Fernando Campos Salles de, e ABRÃO, Carlos Henrique (coord.). Comentários à Lei de Recuperação de Empresas e Falência, 4a ed. São Paulo: Saraiva, 2.010, p. 121.

${ }_{523}$ Art. 30, "caput" c/c art. 24, $\$ 2^{\circ}$, LRE.

${ }^{524}$ Art. 24, "caput", LRE.

${ }^{525}$ No direito comparado analisado, a remuneração do administrador judicial não é determinada livremente pelo mercado, havendo tabelas a serem observadas pelos juízes concursais. Em Portugal, o administrador judicial, quando nomeado pelo juiz, é remunerado de acordo com o montante estabelecido em portaria governamental, além de auferir uma remuneração variável em função do resultado da recuperação do devedor ou da liquidação da massa falida, cujo valor também é fixado em tabelas constantes dessa portaria (art. 23, Lei 22/2.013); e quando o administrador judicial é nomeado pela assembleia de credores, sua remuneração é fixada na mesma deliberação que procede à nomeação (art. 24, Lei 22/2.013); o administrador judicial poderá também receber uma remuneração específica na hipótese de "gestão de estabelecimento compreendido na massa insolvente" (art. 25, Lei 22/2.013) ou quando elabore plano de insolvência (art. 26, Lei 22/2.013). A lei espanhola também prevê, como regra geral, o pagamento do administrador judicial conforme tarifas fixadas por normas e que orientam o juiz, que deverá também atentar para a complexidade do caso em questão (cf. TIRADO, Ignacio. National Report for Spain. In: FABER, Dennis, VERMUT, Niels, 
remuneração do administrador judicial em 5\% (cinco por cento) do valor devido aos credores submetidos à recuperação judicial ou do valor de ativo realizado na falência ${ }^{526}$.

Ao fixar a remuneração do administrador judicial, o juiz deve aplicar os critérios da capacidade de pagamento, da complexidade dos serviços e dos valores de mercado, juntamente com a adequação aos princípios da proporcionalidade, razoabilidade e equidade, além dos princípios da preservação e da função social da empresa ${ }^{527}$. Se por um lado, a fixação somente do teto permite "a cooptação de profissionais capacitados à condução bem-sucedida dos processos", por outro "requer do juiz cautela adicional, à míngua de padrões oficiais, como se verifica em outras legislações, quanto à aferição dos valores praticados no mercado para o desempenho de funções semelhantes, segundo destaca Mauro Rodrigues Penteado ${ }^{528}$.

A remuneração do administrador judicial é, portanto, variável e deverá ser arbitrada caso a caso, devendo o juiz dosar todos os critérios e limites acima expostos. Além do volume e complexidade dos trabalhos e do valor de mercado praticado, o juiz deverá ponderar também, principalmente nos processos de recuperação judicial, a capacidade financeira do devedor, sob pena de inviabilizar a reorganização da empresa. $\mathrm{O}$ trabalho que terá o administrador judicial em uma recuperação judicial de médio porte, por exemplo, será menor do que em uma falência de uma grande empresa com ativo e passivo elevados; por outro lado, se a sociedade em recuperação judicial tiver um grande número

KILBORN, Jason e RICHTER, Tomás. Commencement of Insolvency Proceedings. Oxford: Oxford University Press, 2.012, p. 644.). Já o art. R663-3 e seguintes do Código de Comércio francês estipulam tarifas para a fixação da remuneração do administrador judicial, de acordo com a função exercida, o número de empregados e o volume de negócios do devedor, dentre outros. Da mesma forma que os países europeus acima citados, os juízes norte-americanos fixam a remuneração do administrador judicial, de acordo com tabelas que diminuem a proporção do valor a ser pago conforme o aumento do valor objeto da recuperação judicial ou envolvido na falência (11 USC § 326).

${ }_{526}$ Art. $24, \S 1^{\circ}$, LRE.

527 TJSP, AI n. 0070488-63.2012.8.26.0000, Rel. Des. Roberto Mac Cracken, 2 ${ }^{\text {a }}$ Câmara Reservada de Direito Empresarial, j. 06/11/12, v.u.; TJSP, AI n. 0094886-11.2011.8.26.0000, Rel. Des. Romeu Ricupero, Câmara Reservada à Falência e Recuperação, j. 22/11/11, v.u.; TJSP, Ap. Civ. n. 616.092-4/0-00, Rel. Des. José Roberto Lino Machado, Câmara Reservada à Falência e Recuperação, j. 15/12/09, v.u.

${ }^{528}$ PENTEADO, Mauro Rodrigues. In: CÔRREA-LIMA, Osmar Brina e LIMA, Sérgio Mourão Corrêa (coord.). Comentários à Nova lei de Falência e Recuperação de Empresas: Lei $n^{\circ} 11.101$, de 09 de fevereiro de 2005. $1^{\mathrm{a}}$ ed. Rio de Janeiro: Forense. 2009, p.186. 
de credores ${ }^{529}$ em diversas localizações, poderá demandar muito mais tempo e trabalho do que com uma massa falida com poucos ativos.

Note-se que algumas decisões do Tribunal de Justiça de São Paulo, além de ressaltar a importância da aplicação dos critérios e princípios aqui mencionados, definem como teto máximo da remuneração do administrador judicial, o valor dos vencimentos dos desembargadores do mesmo tribunal, posto ser o administrador judicial um auxiliar do juiz $^{530}$. Em que pese o brilho dos desembargadores relatores de tais acórdãos, ousamos discordar da correlação feita com os vencimentos dos servidores do Poder Judiciário, posto que a forma de trabalho e a estrutura necessária para exercer as funções desempenhadas pelos servidores e pelos administradores judiciais não se confundem. O administrador judicial, com o enfoque dado pela LRE, não trabalhará sozinho; além dos auxiliares previstos no artigo 22 da LRE, deverá contar com uma equipe de profissionais que, evidentemente, serão remunerados com todos os encargos legais; terá também os custos decorrentes do local de trabalho (por exemplo: aluguel, impostos, condomínio, luz, telefone, etc.) e de deslocamentos até as empresas em recuperação judicial, ao local onde estarão situados os bens da massa falida, às assembleias, aos fóruns, etc.; não terá férias, décimo terceiro, abonos ou aposentadorias remuneradas, dentre outros. Ademais, a limitação da remuneração dos administradores judiciais aos vencimentos dos desembargadores estaduais contraria o preceito legal contido no artigo 24, "caput", da LRE, no sentido de que deve ser observado, dentre os demais critérios já expostos, os valores praticados no mercado para atividades semelhantes. Caso esta limitação seja mantida, tememos pelo desestímulo de profissionais competentes e sérios para o exercício da função.

\footnotetext{
${ }^{529}$ TJSP, AI n. 0573241-04.2010.8.26.0000, Rel. Des. Pereira Calças, Câmara Reservada à Falência e Recuperação, j. 29/03/11, v.u.

${ }^{530}$ EMENTA: Agravo de instrumento. Recuperação judicial. Remuneração do Administrador Judicial. Na recuperação judicial, o administrador judicial, auxiliar do juiz, não administra a empresa em recuperação, que continua a ser gerenciada pelo empresário ou pelos administradores estatutários ou contratuais da sociedade recuperanda. Compete ao juiz fixar o valor e a forma de pagamento da remuneração do administrador. $\mathrm{O}$ juiz deve observar a capacidade de pagamento do devedor, o grau de complexidade do trabalho e os valores praticados no mercado para o desempenho de atividades semelhantes. Sendo o administrador judicial um auxiliar do juiz, nesta condição deve ser remunerado, observado o teto dos servidores do Poder Judiciário. Inaplicabilidade da reserva do $\S 2^{\circ}$ do art. 24 da Lei $n^{\circ} 11.101 / 05$ em se tratado de recuperação judicial. Princípios da proporcionalidade, razoabilidade, equidade e modicidade devem ser aplicados no arbitramento da remuneração do administrador judicial. Agravo provido. (TJSP, AI n. 994.09.273351-1, Rel. Des. Pereira Calças, Câmara Reservada à Falência e Recuperação, j. 26/01/10, v.u.). Também neste sentido: TJSP, AI n. 420.655.4/6-00, Rel. Des. Pereira Calças, Câmara Reservada à Falência e Recuperação,j. 25/04/07, v.u.
} 
Embora a LRE não preveja expressamente, a doutrina e a jurisprudência ${ }^{531}$ admitem que o pagamento do administrador judicial seja feito de forma parcelada, durante o processo. Com efeito, em face do tempo que os processos tramitam e tardam em terminar, caso fosse necessário aguardar-se o julgamento de suas contas finais para o recebimento de seus honorários, poucos seriam os profissionais que se interessariam pelo cargo e/ou que poderiam suportar com recursos próprios os custos decorrentes da estrutura e a profissionalização ora exigidas. Não obstante admitir-se a remuneração de forma parcelada, destacamos que ela somente deve ocorrer de forma proporcional ao trabalho realizado $^{532}$ e obedecida a reserva legal de $40 \%$ (quarenta por cento) a seguir discutida, não sendo admitido pagamento antecipado.

Para as hipóteses de falência, o administrador judicial poderá receber no decorrer do processo até o limite de $60 \%$ (sessenta por cento) do montante total da sua remuneração. A LRE determina que os $40 \%$ (quarenta por cento) restantes são reservados para pagamento somente após a aprovação das contas finais prestadas e da apresentação do relatório final do administrador judicial, nos termos dos artigos 154 e 155 da LRE ${ }^{533}$. A remuneração do administrador judicial (e também de seus auxiliares) na falência tem natureza de verba extraconcursal e será paga com prioridade, juntamente com os créditos trabalhistas e decorrentes de acidentes do trabalho relativos a serviços prestados após a decretação da quebra, conforme preceitua o artigo 84, inciso I, da LRE.

A LRE não prevê expressamente a reserva dos $40 \%$ (quarenta por cento) para os casos de recuperação judicial, haja vista que os artigos 154 e 155 citados no parágrafo $2^{\circ}$ do artigo 24 dizem respeito somente ao procedimento da falência; apenas dispõe em seu artigo 63, inciso I, que a sentença de encerramento da recuperação judicial determinará o "pagamento do saldo de honorários ao administrador judicial” após a aprovação da sua prestação de contas e da aprovação do relatório sobre a execução do plano de recuperação.

\footnotetext{
531 TJSP, AI n. 621.286-4/7.00, Rel. Des. Pereira Calças, Câmara Especial de Falências e Recuperações Judiciais de Direito Privado, j. 28/07/09, v.u.; STJ, Resp. n. 1.032.960-PR, Rel. Min Massami Uyeda, $3^{\mathrm{a}}$ Turma, j. 01/06/2010, v.u.

${ }^{532}$ Art. $24, \S 3^{\circ}$, LRE.

${ }^{533}$ Art. $24, \S 2^{\circ}$, LRE.
} 
Doutrina $^{534}$ e jurisprudência ${ }^{535}$ não são unânimes acerca da aplicação da reserva dos $40 \%$ (quarenta por cento) para recuperação judicial. Entendemos que a tal reserva deve ser aplicada apenas nas hipóteses de falência, haja vista que somente nos procedimentos falimentares o administrador judicial efetivamente administra coisa alheia, realiza ativo (recebe créditos da massa, aliena bens arrecadados, etc.), efetua pagamentos, dentre outros, sendo de suma importância o aguardo de sua prestação de contas e respectiva aprovação judicial para o pagamento total de sua remuneração. Já na recuperação judicial, o administrador judicial "não interfere, nem pode interferir na administração da empresa em recuperação" ${ }^{, 536}$, mas apenas fiscaliza suas atividades e o cumprimento do plano. Ademais, o art. 63, inciso I, da LRE apenas de refere ao pagamento de "saldo", o que, não necessariamente, significa dizer "40\% (quarenta por cento) do valor total".

Note-se que a falta de pagamento de eventual saldo dos honorários do administrador judicial pelo devedor, não acarretará a decretação de sua falência, haja vista que a sentença de encerramento da recuperação judicial já terá sido decretada, nos termos do artigo 63 da LRE. Neste caso, deverá o administrador judicial, "valer-se das vias próprias para a satisfação do seu direito" ${ }^{, 537}$.

\footnotetext{
${ }^{534}$ Em posição favorável à reserva de $40 \%$, cf. TOLEDO, Paulo Fernando Campos Salles de, e ABRÃO, Carlos Henrique (coord.). Comentários à Lei de Recuperação de Empresas e Falência. 4a. ed. São Paulo: Saraiva, 2010, p. 121. Em sentido contrário, cf. CAMPINHO, Sérgio. Falência e Recuperação de Empresa: O novo regime da insolvência empresarial. $6^{\mathrm{a}}$ ed. Rio de Janeiro: Renovar, 2.012, p. 69; COELHO, Fábio Ulhoa. Comentários à Lei de Falências e de Recuperação de Empresas. 8a ed. São Paulo: Saraiva, 2011, p. 123, e MOREIRA, Alberto Camiña. In: CÔRREA-LIMA, Osmar Brina e LIMA, Sérgio Mourão Corrêa (coord.). Comentários à Nova lei de Falência e Recuperação de Empresas: Lei $n^{\circ} 11.101$, de 09 de fevereiro de 2005. $1^{\mathrm{a}}$ ed. Rio de Janeiro: Forense, 2.009, p. 425-426.

${ }^{535}$ Em posição favorável à reserva de 40\%: TJSP, AI n. 990.10.031707-5, Rel. Des. Pereira Calças, Câmara Reservada de Direito Empresarial, j. 19/10/10, TJSP, AI n. 2033959-74.2013.8.26.000, Rel. Des. Enio Zuliani, Câmara Reservada de Direito Empresarial, j. 06/02/14; e em posição contrária: TJSP, AI n. 015456131.2013.8.26.000, Rel. Des. Teixeira Leite, $1^{a}$ Câmara Reservada de Direito Empresarial, j. 25/04/14, v.u.; TJSP, AI n. 994.09.273351-1, Rel. Des. Pereira Calças, Câmara Reservada de Direito Empresarial, j. 26/01/10, v.u.; TJSP, AI n. 574.851-4/0-00, Rel. Des. José Roberto Lino Machado, Câmara Especial de Falências e Recuperações Judiciais, j. 29/10/08, v.u.; e TJRJ, AI n. 2009.002.41700 (004437220.2009.8.19.0000), Rel. Des. Ferdinando Nascimento, $19^{a}$ Câmara Cível, j. 09/10/10, v.u.

${ }^{536}$ TJSP, AI n. 994.09.273351-1, Rel. Des. Pereira Calças, Câmara Reservada de Direito Empresarial, j. 26/01/10, v.u.

${ }^{537}$ MUNHOZ, Eduardo Secchi. In: SOUZA JUNIOR, Francisco Satiro de, e PITOMBO, Antônio Sérgio de A. Moraes. (coord.). Comentários à Lei de Recuperação de Empresas e Falência. Lei 11.101/2005. - Artigo por Artigo.. $2^{\mathrm{a}}$ ed. São Paulo: Revista dos Tribunais, 2.007, p. 307.
} 
Caso ocorra a substituição do administrador judicial, o substituído fará jus ao recebimento proporcional ao trabalho realizado, exceto se houver renunciado sem razão relevante ${ }^{538}$.

O administrador judicial perderá o direito à remuneração ${ }^{539}$ e terá que devolver o que já recebeu, nas hipóteses de destituição já relacionadas no tópico 3.6 supra.

Não restam dúvidas de que na recuperação judicial, a remuneração do administrador judicial é feita pelo devedor, enquanto que, na falência, seus honorários são suportados pela massa falida ${ }^{540}$.

Todavia, face ao silêncio da LRE, questão de difícil resposta diz respeito a como proceder nos casos de insuficiência de bens da massa falida para o pagamento das despesas processuais, inclusive da remuneração do administrador judicial.

A solução que tem sido encontrada pela doutrina ${ }^{541}$ e pela jurisprudência paulista $^{542}$ é a adoção da mesma regra contida no artigo 75 da antiga LF, ou seja, o adiantamento do numerário necessário por um ou por parte dos credores. Tal entendimento é justificado pelo fato de que o administrador judicial não trabalhará sem a devida remuneração e também não poderá ser nomeado para a sua função o próprio credor, como ocorria no diploma legal anterior, justamente por não atender aos requisitos do artigo 21 da LRE. Os valores adiantados serão considerados encargos da massa e, portanto, esses credores que contribuirem com o pagamento terão prioridade no recebimento. Caso o credor que requereu a falência (ou, eventualmente demais credores) não queira efetuar a caução, a solução encontrada é o encerramento sumário da falência. Note-se que algumas das decisões jurisprudenciais paulistas enfatizam, inclusive, que, face à omissão da LRE,

\footnotetext{
${ }^{538}$ Art. $24, \S 3^{\circ}$, LRE.

${ }^{539}$ Art. $24, \S \S 3^{\circ}$ e $4^{\circ}$, LRE.

${ }^{540}$ Art. $25 \mathrm{c} / \mathrm{c}$ art. 84, inc. I, LRE.

541 PENTEADO, Mauro Rodrigues. In: CÔRREA-LIMA, Osmar Brina e LIMA, Sérgio Mourão Corrêa (coord.). Comentários à Nova lei de Falência e Recuperação de Empresas: Lei $n^{\circ} 11.101$, de 09 de fevereiro de 2005. $1^{\mathrm{a}}$ ed. Rio de Janeiro: Forense. 2009, p. 189-190; VERÇOSA, Haroldo Malheiros Duclerc. In: SOUZA JUNIOR, Francisco Satiro de, e PITOMBO, Antônio Sérgio de A. Moraes. (coord.). Comentários à Lei de Recuperação de Empresas e Falência. Lei 11.101/2005. - Artigo por Artigo. 2a ed. São Paulo: Revista dos Tribunais, 2007, p. 178.

${ }^{542}$ TJSP, AI n. 582.469-4/0-00, Rel. Des. Romeu Ricupero, Câmara Especial de Falências e Recuperações Judiciais, j. 19/11/08, v.u.; TJSP, AI n. 560.692-4/6-00, Rel. Des. Elliot Akel, Câmara Especial de Falências e Recuperações Judiciais, j. 07/05/08, v.u.
} 
aplica-se a lei processual no sentido de que o requerente da falência tem "ônus decorrentes do dever de estar em Juízo", devendo prover as despesas dos atos processuais e cumprir com exatidão os provimentos judiciais, de natureza antecipatória ou final, “ex vi” do disposto nos artigos 14 a 35 do $\mathrm{CPC}^{543}$.

Todavia, em recente julgamento de recurso especial interposto em face de acórdão proferido pelo Tribunal de Justiça do Estado de São Paulo nos termos acima expostos, o Superior Tribunal de Justiça afastou a exigência de caução, sob pena de extinção do feito, posto que "não encontra respaldo legal" e determinou a nomeação de novo administrador judicial ${ }^{544}$. Neste acórdão, o Relator Mininstro Paulo de Tarso Sanseverino destaca que, se por um lado não se pode obrigar o administrador judicial a aceitar o "múnus", poderá, por outro lado, o magistrado deixá-lo de nomear em outro processo, "especialmente porque tem de ser profissional da sua confiança, indivíduo ou pessoa jurídica com o qual possa contar para o seu fiel e eficiente auxílio”.

Ainda que concordemos com o voto exaurido no recurso especial acima indicado, no sentido de não ser possível atribuir o ônus da caução ao credor, sendo, na verdade, apenas uma faculdade a ele conferida, a solução de se nomear novo administrador não resolverá o problema nos casos em que não se encontrem profissionais dispostos a aceitar o encargo. Nestas hipóteses ou se admitirá a extinção sumária do processo com o encerramento da falência (solução que nos parece viável nos casos de inexistência de ativos), ou será necessária a utilização de algum outro profissional, tal como ocorre no Rio de Janeiro com o liquidante judicial ${ }^{545}$, por exemplo, ou a previsão de alguma forma de remuneração para os "procedimentos sem recursos financeiros" 546, como já ocorre em outros países $^{547}$, o que acreditamos ser mais adequado para os casos em que haja ativos,

\footnotetext{
543 TJSP, Apelação n. 0014677-90.2009.8.26.0302, Rel. Des. Ricardo Negrão, 2 ${ }^{\text {a }}$ Câmara Reservada de Direito Empresarial, j. 19/08/03, v.u.

${ }^{544}$ STJ, Resp n. 1.236.713-SP, Rel. Min. Paulo de Tarso Sanseverino, $3^{\text {a }}$ Turma, j. 07/05/14, v.u.

545 Art. 406 e ss., Consolidação Normativa da Corregedoria Geral da Justiça do Estado do Rio de Janeiro Parte Judicial. TRIBUNAL DE JUSTIÇA DO ESTADO DO RIO DE JANEIRO. Corregedoria Geral de Justiça. Disponível em http://www.tjrj.jus.br/documents/1017893/1038412/cncgj-judicial.pdf. Acesso em 02/02/2.014.

${ }^{546}$ GUIMARÃES, Márcio Souza. Le role du ministère public dans lês procédures collectives (approche de droit compare français et brésilien). Villeneuve d'Ascq: Atelier National de Reproduction des Thèses: 2.011, p. 441.

${ }^{547}$ Em Portugal, para os casos em que a massa falida é insuficiente para a satisfação das custas do processo, após ouvir o devedor, a assembleia de credores e os credores da massa insolvente declara encerrado o processo, exceto se algum interessado prestar caução do montante determinado pelo juiz (art. 39 c/c art. 232, Decreto-Lei 53/04). Todavia, a remuneração do administrador judicial e o reembolso de suas despesas são
} 
embora sejam poucos e insuficientes, inclusive para estimular o ingresso de mais profissionais comprometidos nesta função.

suportados pelo organismo responsável pela gestão financeira e patrimonial do Ministério da Justiça (art. 30, Lei 22/2.013 e Portaria 51/2005 do Ministério das Finanças e da Administração Pública). Já na Alemanha, para os casos em que a massa não seja suficiente para arcar com a remuneração do administrador judicial, este tem "direito a pleiteá-la da caixa estadual (Staatscasse) do território (Länder) onde está situado o tribunal que indicou o administrador judicial" conforme explicam Vera Helena de Mello e Franco e Raquel Sztajn. FRANCO, Vera Helena de Mello e SZTAJN, Rachel. Falência e Recuperação de Empresa em Crise. $1^{\mathrm{a}}$ ed. Rio de Janeiro. Elsevier, 2.008, p. 68. 


\section{Conclusão.}

1. A LRE acompanha a tendência internacional de adoção de um sistema jurídico que possibilite a reorganização das empresas e devedores viáveis e a liquidação das sociedades e devedores inviáveis.

2. O administrador judicial, órgão auxiliar da justiça, assume papel de relevada importância dentro do novo contexto de preservação das empresas viáveis e extinção das empresas, cujo prosseguimento não seja mais justificável, da forma mais célere e eficiente possível.

3. O administrador judicial exerce "munus" público, haja vista receber encargo de atuar na recuperação judicial ou na falência, em decorrência de disposição legal. Ele é órgão de confiança do juiz e atua sob a fiscalização do comitê de credores, se houver, estando sujeito a um regime jurídico que especificamente lhe traça a LRE; não é funcionário público e nem a ele equiparado.

4. Para que o administrador judicial atenda aos requisitos legais deve ser "profissional idôneo" ou "pessoa jurídica especializada", sendo o rol constante do art. 21 da LRE meramente exemplificativo. Pressupõe-se que a idoneidade seja financeira e moral, e que esteja presente em todo o administrador judicial, pessoa física ou jurídica.

5. Embora não previsto em lei, o administrador judicial deverá ser independente e imparcial e deter experiência e conhecimentos técnicos, sobretudo na área de negócios, para atender às finalidades de sua função. Para que sua atuação esteja em consonância com os objetivos da LRE e para que o devedor em recuperação judicial ou a massa falida sejam onerados da menor forma possível, é desejável que o administrador judicial seja profissional dotado de equipe multidisciplinar.

6. Atendidos os requisitos constantes da LRE e, eventualmente, outras exigências formais determinadas pelos Tribunais de Justiça de cada Estado, e desde que não seja caracterizada nenhuma das hipóteses de impedimento previstas em lei, a escolha do administrador judicial fica a critério exclusivo do magistrado, sem necessidade de prévia oitiva de credores, do devedor e/ou de terceiros interessados na recuperação judicial ou na 
falência. Caberá ao magistrado ponderar as características de cada candidato a administrador judicial a fim de garantir a imparcialidade e a independência necessárias a este órgão. Na hipótese de o administrador judicial ser pessoa jurídica, os impedimentos de ordem pessoal deverão ser aplicados aos seus administradores e representantes legais, e também ao profissional que assinou o termo de compromisso.

7. Da análise do direito comparado, verificamos a tendência de utilização de listas oficiais com os nomes dos administradores judiciais, que previamente foram aprovados em exames de admissão, estágios probatórios e provas finais. A escolha de nome não constante dessas listas só ocorre em casos específicos que justifiquem experiência ou qualificação especial ou, excepcionalmente, nas hipóteses de falta de confiança do juiz. Além de uma exigência muito maior nos requisitos obrigatórios para o acesso ao cargo, é necessária a comprovação de caução ou seguro de responsabilidade civil, para a investidura e manutenção do administrador judicial nas suas funções. A realização de cursos de aperfeiçoamento e atualização, bem como a criação de um estatuto ou código de ética, dotado de um sistema disciplinar e de regras de conduta também se mostram de suma relevância para um melhor funcionamento do sistema jurídico.

8. Os deveres e atribuições do administrador judicial não se resumem ao rol do artigo 22 e a outros esparsos na LRE. Como órgão auxiliar da justiça e de confiança do juiz, o administrador judicial deve exercer todas as funções necessárias para desempenhar o cargo assumido da maneira mais eficaz e completa possível. Embora existam funções comuns e de grande relevância, como por exemplo, a verificação e organização dos créditos e o requerimento de convocação e presidência das assembleias gerais de credores, a grande maioria das funções do administrador judicial na recuperação judicial diferem substancialmente das exercidas na falência. Na recuperação judicial, sua principal atividade é a de fiscalização das condutas do devedor e do cumprimento do plano de recuperação, e, apenas em caráter excepcional e "pro tempore" a gestão da empresa. Já na falência, o administrador judicial assume a administração e representação da massa falida, sendo responsável pela arrecadação, avaliação, guarda e alienação dos ativos, para posterior pagamento aos credores. Embora não previstos de forma expressa na LRE, ao administrador judicial são impostos os deveres de obediência aos preceitos legais e de diligência, lealdade e boa-fé na sua atuação, em decorrência do disposto nos artigos 31, 33 e 177 da lei. Outrossim, por ser auxiliar eventual da justiça e por aceitar o "munus" público 
a ele conferido, deve observar os deveres de lealdade, de obediência e de conduta ética dos servidores públicos, mesmo não sendo agente público. Por outro lado, na administração da massa falida e nos casos excepcionais de gestão na recuperação judicial ou manutenção das atividades da falida pelo administrador judicial, devem ser aplicados, por analogia, os seguintes deveres fiduciários dos administradores de sociedades: dever de diligência, dever de dar cumprimento às finalidades das atribuições do cargo, dever de lealdade, deveres próprios sobre conflito de interesses, e dever geral de vigilância. $\mathrm{O}$ cuidado e a diligência a serem aplicados pelo administrador judicial devem ser entendidos como superiores aos da figura do "pai de família", não obstante a redação dada pelo Código Civil e pela Lei 6.404/76, haja vista que suas atividades demandam uma especialização e exigem caráter profissional.

9. O administrador judicial assume diversas responsabilidades a partir do momento da sua investidura no cargo. A LRE apenas trata de responsabilidade do administrador judicial no âmbito cível e penal, mas o CTN contém dispositivo expresso no que diz respeito à esfera tributária. Na hipótese de o administrador judicial assumir a gestão da empresa na recuperação judicial ou prosseguir com as atividades da falida, ainda que de forma temporária, será equiparado a um verdadeiro administrador, e, portanto, nessa qualidade poderá ser responsabilizado nas diversas áreas do direito.

10. O artigo 32 da LRE prestigia a responsabilidade civil subjetiva do administrador judicial, que responde por culpa ou dolo pelos prejuízos que causar ao devedor, à massa falida e aos credores de maneira geral. Não obstante seja evidente que o novo administrador judicial tenha legitimidade para propor a devida ação de indenização, qualquer credor ou o devedor que tenha sido lesionado diretamente poderá figurar no polo ativo da ação. A responsabilidade do administrador judicial será objetiva no tocante a atos práticos pelos seus prepostos e empregados, em face do disposto nos artigos 932, inciso III, e 933 do Código Civil; todavia, não responderá pelos auxiliares designados pelo juízo, exceto se também agir com culpa ou dolo concorrente.

11. O administrador judicial praticará crime próprio de violação de impedimento (artigo 177 da LRE) caso adquira diretamente ou através de terceiro, bens da massa falida ou da devedora em recuperação judicial, ou entre em alguma especulação de lucro, nos processos que atuar. Além disso, poderá ser responsabilizado criminalmente por outras 
condutas também tipificadas como crime na LRE. Para efeitos penais, o administrador judicial é equiparado ao devedor ou ao falido, respondendo na medida de sua culpabilidade (artigo 179 da LRE), mas não ao funcionário público.

12. Tendo em vista que o administrador judicial não pratica atos de gestão do devedor em recuperação judicial, muito difícil se vislumbrar sua responsabilidade tributária nos casos de reorganização. A decretação da falência da empresa por si só também não gera a responsabilidade do administrador judicial pelos tributos e encargos moratórios - a massa falida é sucessora tributária e assim responderá com seu patrimônio durante o processo de liquidação, e o administrador judicial responderá única e exclusivamente se presentes as condições a seguir apontadas. A responsabilidade tributária do administrador judicial apresenta-se como solidária, na hipótese do artigo 134, inciso V, e, excepcionalmente, como de caráter pessoal, na hipótese do artigo 135, inciso I, ambos do CTN. A responsabilidade solidária pressupõe que a massa falida não possa cumprir sua obrigação e que o administrador judicial seja responsável pelo ato que configure o fato gerador do tributo, ou em relação a este tenha indevidamente se omitido, e, em decorrência deste ato (ou omissão) seja impossível exigir-se a cumprimento da obrigação pela massa falida. A responsabilidade pessoal prevista no artigo 135, inciso I, do CTN decorre de atos praticamente diretamente pelo administrador judicial com excesso ou abuso de poder. $\mathrm{Na}$ hipótese de manutenção das atividades negociais da falida, o administrador judicial responderá de forma pessoal por seus atos e omissões, como também ocorre com o gestor judicial na recuperação judicial, da mesma maneira que respondem os administradores das sociedades empresárias em geral.

13. O administrador judicial não detém direito subjetivo para permanecer no cargo, razão pela qual pode ser substituído a qualquer tempo, desde que haja a perda de confiança do juiz ou se verifique alguma das situações previstas no artigo 30 da LRE, ou haja a renúncia imotivada; a morte ou interdição; a falência, recuperação judicial ou dissolução do administrador judicial. Diferentemente da substituição, a destituição é sanção e somente será imposta ao administrador judicial após o contraditório e a ampla defesa, e mediante a prova concreta de desobediência dos preceitos da LRE; ou de descumprimento dos deveres e obrigações que lhe são atribuídos no momento da investidura no cargo; ou de omissão, negligência, ou prática de ato lesivo às atividades do devedor ou a terceiros. A substituição e a destituição geram efeitos distintos na remuneração do administrador judicial: nas 
situações em que o administrador judicial é substituído, sua remuneração será proporcional ao trabalho realizado, exceto se a substituição decorreu de renúncia imotivada; já na destituição, além de ficar impedido de atuar em outra recuperação judicial ou falência pelo prazo de cinco anos, o até então administrador judicial perderá o direito de remuneração.

14. A remuneração do administrador judicial é fixada pelo magistrado, não podendo ultrapassar o teto de 5\% (cinco por cento) do valor devido aos credores submetidos à recuperação judicial ou do valor do ativo realizado na falência. Para a sua fixação, o magistrado deverá aplicar os critérios da capacidade de pagamento pelo devedor, da complexidade dos serviços e dos valores de mercado praticados para o desempenho de atividades semelhantes, juntamente com a adequação aos princípios da proporcionalidade, razoabilidade e equidade, além dos princípios da preservação e da função social da empresa. O pagamento poderá ser efetuado de forma parcelada e proporcional ao trabalho realizado, não sendo admitido pagamento antecipado. A reserva de $40 \%$ (quarenta por cento) do montante de sua remuneração deve ser efetuada somente para as hipóteses de falência e até a aprovação das contas finais prestadas e da apresentação do relatório final do administrador judicial. 


\section{Bibliografia}

ABRÃO, Nelson. $O$ síndico na falência. $2^{\mathrm{a}}$ ed. São Paulo: Liv. e Ed. Universitária de Direito, 1.999.

A Continuação do Negócio na Falência. $1^{a}$ ed. São Paulo: Liv. e Ed.

Universitária de Direito, 1.975.

Curso de direito falimentar. $2^{\mathrm{a}}$ ed. São Paulo: Saraiva, 1.980.

ADAMEK, Marcelo Vieira von. Responsabilidade civil dos administradores de S/A (e as ações correlatas). $1^{\text {a }}$ ed. São Paulo: Saraiva, 2.009.

ALBERGOTTI, Robert. Understanding Bankruptcy in the US - a handbook of law and practice. Massachuttes: Blackwell Finance, 1.992.

ALMEIDA, Roberto Fernandes de. Administrador de falência. Justitia. Vol. 134. São Paulo, 1.986.

ALVIM, Arruda. Manual de Direito Processo Civil. 13 ${ }^{\text {a }}$ ed. São Paulo: Revista dos Tribunais, 2.010 .

AMERICAN BANKRUPTCY INSTITUTE. Fiduciary Duties - during the chapter 11 case.

http://www.abiworld.org/committees/newsletters/young/vol7num2/The_Importance of_Un derstanding_Fiduciary_Duties.pdf.p. 11-12. Acesso em 01/05/2.014.

ARAUJO, José Francelino de. $O$ síndico na Administração da Falência. $1^{\text {a }}$ ed. São Paulo: Revista dos Tribunais, 1.985.

ASCARELLI, Tullio. A atividade do empresário. Trad. Erasmo Valladão A. e N. França. Revista de Direito Mercantil, Industrial, Econômico e Financeiro. São Paulo. Malheiros. Ano XLII, n. 132, Outubro-Dezembro/2.003. 
ASQUINI, Alberto. Profili dell'impresa, in Rivista del Diritto Commerciale, 1943, v. 41, I. Trad. Fábio Konder Comparato. Perfis da empresa. Revista de Direito Mercantil, Industrial, Econômico e Financeiro. São Paulo. Malheiros. Ano XXXV, n. 104, OutubroDezembro/1.996.

BAIRD, Douglas G. The Elements of Bankruptcy. Nova Iorque: Foudantion Press. 3a. ed., 2.001 .

BALBINO, Paulo de Carvalho. In: CÔRREA-LIMA, Osmar Brina e LIMA, Sérgio Mourão Corrêa (coord.). Comentários à Nova lei de Falência e Recuperação de Empresas: Lei $n^{o} 11.101$, de 09 de fevereiro de 2005. $1^{\mathrm{a}}$ ed. Rio de Janeiro: Forense, 2.009.

BALEEIRO, Aliomar. Direito Tributário Brasileiro. $11^{\mathrm{a}}$ ed. Rio de Janeiro: Forense, 2.005.

BANDEIRA DE MELLO, Celso Antônio. Curso de Direito Administrativo. 30a ed. São Paulo: Malheiros, 2013.

BARRETO FILHO, Oscar. Teoria do Estabelecimento Comercial. São Paulo: Max Limonad, 1.969.

BERGER, Dora. A insolvência no Brasil e na Alemanha. Estudo Comparado entre a Lei de Insolvência Alemã de 01.01.1999 (Traduzida) e o Projeto de Lei Brasileiro $n^{\circ} 4.376$ de 1993 (com as alterações de 1999) que Regula a Falência, a Concordata Preventiva e a Recuperação das Empresas.1 ${ }^{\mathrm{a}}$ ed. Porto Alegre: Sergio Antonio Fabris, 2.001.

BERTOLDI, Marcelo. In: CÔRREA-LIMA, Osmar Brina e LIMA, Sérgio Mourão Corrêa (coord.). Comentários à Nova lei de Falência e Recuperação de Empresas: Lei $n^{o} 11.101$, de 09 de fevereiro de 2005. $1^{\mathrm{a}}$ ed. Rio de Janeiro: Forense, 2.009.

BEZERRA FILHO, Manoel Justino. Jurisprudência da Nova Lei de Recuperação de Empresas e Falências. Decisões, ofícios judiciais, resoluções, sentenças, acórdãos, dentre outros documentos. $1^{\mathrm{a}}$ ed. São Paulo: Revista dos Tribunais, 2.006. 
Lei de Recuperação de Empresas e Falências Comentada, $5^{\mathrm{a}}$ ed. São Paulo: Revista dos Tribunais, 2008.

.A verificação e a habilitação de créditos na recuperação judicial e na falência. In: A Nova Lei de Falências e de Recuperação de Empresas. Revista do Advogado n. 83, São Paulo: AASP, 2.005.

BIOLCHI, Osvaldo Anicetto. A nova Lei de Recuperação de Empresas e Falências. In: A Nova Lei de Falências e de Recuperação de Empresas. Revista do Advogado n. 83, São Paulo: AASP, 2.005.

BORGES, Eduardo de Carvalho e KNOPFELMACHER, Marcelo. A responsabilidade tributária dos Sucessores perante a Nova Lei de Falências e de Recuperação de Empresas. In: CASTRO, Rodrigo R. Monteiro de e ARAGÃO, Leandro Santos de (coord.). Direito Societário e a Nova Lei de Falências e Recuperação de Empresas. São Paulo: Quartier Latin, 2.006.

BULGARELLI, Waldirio. Direito Comercial. 12ª ed. São Paulo: Atlas, 1.997.

CAMILO JÚNIOR, Ruy Pereira. Empresa em Crise e Tributação. In: TOLEDO, Paulo Fernando Campos Salles de; e SOUZA JUNIOR, Francisco Satiro de, (coord.). Direito das Empresas em Crise: Problemas e Soluções. $1^{\mathrm{a}}$ ed. São Paulo: Quartier Latin, 2.012.

CAMPINHO, Sérgio. Falência e Recuperação de Empresa: O novo regime da insolvência empresarial. $6^{\text {a }}$ ed. Rio de Janeiro: Renovar, 2.012.

CARVALHO DE MENDONÇA. José Xavier. Tratado de Direito Comercial. Vol. VIII. $2^{\mathrm{a}}$. ed. Rio de Janeiro: Freitas Bastos, 1.962.

CARVALHOSA, MODESTO. In: CÔRREA-LIMA, Osmar Brina e LIMA, Sérgio Mourão Corrêa (coord.). Comentários à Nova lei de Falência e Recuperação de Empresas: Lei $n^{o}$ 11.101, de 09 de fevereiro de 2005. $1^{\mathrm{a}}$ ed. Rio de Janeiro: Forense. 2.009. 
CASTRO, Rodrigo R. Monteiro de, e ARAGÃO, Leandro Santos de. (coord.). Direito Societário e a Nova Lei de Falências e Recuperação de Empresas. 1ª ed. São Paulo: Quartier Latin, 2.006.

CEREZETTI, Sheila Christina Neder. A Recuperação Judicial de Sociedade por Ações. $O$ Princípio da Preservação da Empresa na Lei de Recuperação e Falência. $1^{\text {a }}$ ed. São Paulo: Malheiros, 2.012.

CHEDIAK. Julian Fonseca Peña. O conflito de interesses do Administrador de Sociedade Anônima: uma Sugestão de Alteração no Enfoque do Tema. In: ADAMEK, Marcelo Vieira von. (coord.). Temas de Direito Societário e Empresarial Contemporâneos. $1^{\mathrm{a}}$ ed. São Paulo: Malheiros, 2.011.

COELHO, Fábio Ulhoa. Comentários à Lei de Falências e de Recuperação de Empresas. $8^{\mathrm{a}}$ ed. São Paulo: Saraiva, 2.011.

Curso de direito comercial. Direito de empresa. Vol. 3, 12a edição. São Paulo: Saraiva, 2.011.

Curso de Direito Civil, vol. 1. São Paulo: Saraiva. 2.003.

COGAN, ARTHUR. Crimes contra a administração pública. São Paulo: Juarez de Oliveira, 2003.

COOTER, Robert e FREEDMAN, Bradley J. The Fiduciary Relationship: its economic character and legal consequences. New York University Law Review n 1045. October 1.991.

CÔRREA-LIMA, Osmar Brina e LIMA, Sérgio Mourão Corrêa (coord.). Comentários à Nova lei de Falência e Recuperação de Empresas: Lei $n^{o}$ 11.101, de 09 de fevereiro de 2005. $1^{\mathrm{a}}$ ed. Rio de Janeiro: Forense. 2.009.

DAOUN, Alexandre Jean (coord.). Crimes falimentares. 1ª ed. São Paulo: Quartier Latin, 2.006 . 
DE LUCCA, Newton e DOMINGUES, Alessandra de Azevedo (coord.). Direito Recuperacional. Aspectos Teóricos e Práticos. 1ª ed. São Paulo: Quartier Latin, 2.009.

DE LUCCA, Newton e SIMÃO FILHO, Adalberto (coord.). Comentários à Nova Lei de Recuperação de Empresas e Falências, $1^{\mathrm{a}}$ ed. São Paulo: Quartier Latin, 2.005.

DELMANTO, Celso, DELMANTO, Roberto, DELMANTO JUNIOR Roberto, e DELMANTO, FABIO Machado de Almeida. Código Penal Comentado. $7^{\mathrm{a}}$ ed. Rio de Janeiro: Renovar, 2.007.

DENARI, Zelmo. Sujeitos Ativo e Passivo da Relação Jurídica Tributária. In: MARTINS, Ives Gandra da Silva (coord.). Curso de Direito Tributário. $7^{\mathrm{a}}$ ed. São Paulo: Saraiva, 2.000 .

DERZI, Misabel Abreu Machado e COÊLHO, Sacha Calmon Navarro. Da Não-Incidência do Imposto de Renda sobre as Operações Realizadas no Curso do Processo da Falência. Revista Dialética de Direito Tributário, $\mathrm{n}^{\circ}$. 45. Dialética: São Paulo.

DINAMARCO, Candido Rangel. Instituições de Direito Processual Civil. Vol I. $4^{\mathrm{a}}$ ed. São Paulo: Malheiros, 2.004.

DI PIETRO, Maria Sylvia Zanella. Direito Administrativo. 27ª ed. São Paulo: Atlas, 2014.

DUPOUX, Cécile e NERGUARARIAN, Carole. National Report for France. In: FABER, Dennis, VERMUT, Niels, KILBORN, Jason e RICHTER, Tomás Commencement of Insolvency Proceedings. Oxford: Oxford University Press, 2.012.

EIZIRIK, Nelson. Temas de Direito Societário. $1^{\mathrm{a}}$ ed. Rio de Janeiro: Renovar, 2.005.

EUROPEAN BANK FORM RECONSTRUCTION AND DEVELOPMENT. EBRD $\begin{array}{lllll}\text { Insolvency } \quad \text { Office } & \text { Holder } & \text { Principles. } & \text { Disponível }\end{array}$ http://www.ebrd.com/downloads/legal/insolvency/ioh_principles.pdf. Acesso em $05 / 01 / 2.014$. 
FABER, Dennis, VERMUT, Niels, KILBORN, Jason e RICHTER, Tomás. Commencement of Insolvency Proceedings. Oxford: Oxford University Press, 2.012.

FASSI, Santiago C. e GEBHARDT, Marcelo. Concursos y Quiebras Comentario exegético de La Ley 24.522 Jurisprudencia aplicable. 8a ed. Buenos Aires: Astrea, 2.004.

FAVIER-DUBOIS, Eduardo M. Concursos y Quiebras. 2a ed. Buenos Aires: Errepar, 2.005 .

FAZZIO JUNIOR, WALDO. Lei de Falências e Recuperação de Empresas. 4a ed. São Paulo: Atlas, 2.008.

FERREIRA, Waldemar. Tratado de Direito Comercial. Vol. 15. São Paulo: Saraiva, 1.966.

FONSECA, Humberto Lucena Pereira. In: CÔRREA-LIMA, Osmar Brina e LIMA, Sérgio Mourão Corrêa (coord.). Comentários à Nova lei de Falência e Recuperação de Empresas: Lei $n^{o} 11.101$, de 09 de fevereiro de 2005. $1^{\mathrm{a}}$ ed. Rio de Janeiro: Forense. 2.009.

FRANÇA, Erasmo Valladão Azevedo e Novaes. Conflito de Interesses nas Assembleias de S.A. $1^{\text {a }}$ ed. São Paulo: Malheiros, 1.993.

Temas de Direito Societário, Falimentar e Teoria da Empresa. $1^{\text {a }}$ ed. São Paulo: Malheiros, 2.009.

. In: SOUZA JUNIOR, Francisco Satiro de, e PITOMBO, Antônio Sérgio de A. Moraes. (coord.). Comentários à Lei de Recuperação de Empresas e Falência. Lei 11.101/2005. - Artigo por Artigo. $2^{\mathrm{a}}$ ed. São Paulo: Revista dos Tribunais, 2.007.

FRANCO, Vera Helena de Mello. In: SOUZA JUNIOR, Francisco Satiro de, e PITOMBO, Antônio Sérgio de A. Moraes. (coord.). Comentários à Lei de Recuperação de Empresas e Falência. Lei 11.101/2005. - Artigo por Artigo. 2a ed. São Paulo: Revista dos Tribunais, 2.007 . 
FRANCO, Vera Helena de Mello, e SZTAJN, Rachel. Falência e Recuperação de Empresa em Crise. $1^{\text {a }}$ ed. Rio de Janeiro. Elsevier, 2.008.

FRONTINI, Paulo Salvador. In: SOUZA JUNIOR, Francisco Satiro de, e PITOMBO, Antônio Sérgio de A. Moraes. (coord.). Comentários à Lei de Recuperação de Empresas e Falência. Lei 11.101/2005. - Artigo por Artigo. 2a ed. São Paulo: Revista dos Tribunais, 2.007 .

GIASANTE, David C. O administrador judicial no processo falimentar. In: LAZZARINI, Alexandre A., KODAMA, Thais e CALHEIROS, Paulo (coord.). Recuperação de Empresas e Falência. Aspectos práticos e relevantes da Lei 11.101/05. 1ª ed. São Paulo: Quartier Latin, 2.014.

GIASANTE, Gilberto. Um ensaio prático sobre a recuperação judicial especial: a visão do advogado e do administrador judicial. In: DE LUCCA, Newton e DOMINGUES, Alessandra de Azevedo (coord.). Direito Recuperacional. Aspectos Teóricos e Práticos. $1^{\text {a }}$ ed. São Paulo: Quartier Latin, 2.009.

GIL, Laura Zumaquero. La responsabilidad civil de los administradores concursales. http://www.indret.com/pdf/950.pdf. Acesso em 20/05/14.

GOMES, ORLANDO. Contratos. 12a ed. Rio de Janeiro: Forense, 2.008.

GONÇALVES NETO, Alfredo de Assis. Administração da Falência, Realização do Ativo e Pagamento dos Credores. In: SANTOS, Paulo Penalva (coord.). A Nova Lei de Falências e Recuperação de Empresas. Lei 11.101/05. 1ª ed. Rio de Janeiro: Forense, 2.007.

GUIMARÃES, Márcio Souza. Le role du ministère public dans lês procédures collectives (approche de droit compare français et brésilien). Villeneuve d'Ascq: Atelier National de Reproduction des Thèses: 2.011.

.O Direito Francês como Exemplo de Prevenção à Crise da Empresa: Instrumentos Preventivos de Dificuldades das Empresas. In: COELHO, Fábio Ulhoa, 
Apontamentos sobre o direito das empresas em dificuldade (droit des entrepises en difficulté) em França. In: Recuperação Judicial: temas polêmicos. Revista do Advogado n. 105, São Paulo: AASP, 2.009.

HUNGRIA, Nelson. Comentários ao Código Penal. Vol. IX, $4^{\mathrm{a}}$ ed. Rio de Janeiro: Forense, 1.958.

JACKSON, Thomas H.. The logic and Limits of Bankruptcy Law. Washington, D.C.: BeardBooks, 1.986.

JACQUEMONT, André. Droit des Entrepises en Difficulté. $3^{\mathrm{a}}$ ed. Paris: Litec, 2.003.

JUSTEN FILHO, Marçal. Curso de Direito Administrativo. $9^{a}$ ed. São Paulo: Revista dos Tribunais, 2013.

KILBORN, Jason. National Report for the United States. In: FABER, Dennis, VERMUT, Niels, KILBORN, Jason e RICHTER, Tomás. Commencement of Insolvency Proceedings. Oxford: Oxford University Press, 2.012.

KUGELMAS, Alfredo Luiz e ARRUDA PINTO, Gustavo Henrique Sauer de. Administrador Judicial na recuperação judicial: aspectos práticos. In: DELUCCA, Newton e DOMINGUES, Alessandra de Azevedo (coord.). Direito Recuperacional. Aspectos Teóricos e Práticos. 1ª ed. São Paulo: Quartier Latin, 2.009.

LACERDA, José Candido Sampaio de. Manuel de direito falimentar. $14^{\mathrm{a}}$ ed. Atualizada por Jorge de Miranda Magalhães. Rio de Janeiro: Freitas Bastos, 1.999.

LASTRES, José Luis García-Pita y. La separación de los administradores concursales por prolongación indebida le la liquidación. http://dictumabogados.com/files/2014/04/separacion-administracion-concursalprolongacion-liquidacion.pdf. Acesso em 20/05/2014.

LEITE, Eduardo Oliveira. Monografia Jurídica. 9a ed. São Paulo: Revista dos Tribunais, 2.011 . 
LIMA, Tiago Astor Rocha e NUNES, Marcelo Guedes. Reflexões sobre o projeto do Código Comercial. São Paulo: Saraiva, 2013.

LISBOA, Marcos de Barros, DAMASO, Otávio Ribeiro, Santos, Bruno Carazza dos, COSTA, Ana Carla Abrão. A Racionalidade Econômica da Nova Lei de Falências e de Recuperação de Empresas. In: PAIVA, Luiz Fernando Valente de (coord.). Direito Falimentar e a nova lei de falências e recuperação de empresas. São Paulo: Quartier Latin, 2.005 .

LOOSE, Peter, GRIFFITHS, Michael. Loose on Liquidators. 7a. ed. Bristol: Jordan Publishing Limited, 2.012.

LOPES, Bráulio Lisboa. Aspectos Tributários da Falência e da Recuperação de Empresas. São Paulo: Quartier Latin, 2.008.

LUCENA, Adriana. O tratamento legal da propriedade intelectual na falência e na recuperação de empresas. In: TOLEDO, Paulo Fernando Campos Salles de; e SOUZA JUNIOR, Francisco Satiro de (coord.). Direito das Empresas em Crise: Problemas e Soluções. $1^{\mathrm{a}}$ ed. São Paulo: Quartier Latin, 2.012.

MACHADO, Hugo de Brito. Curso de Direito Tributário. 28 ed. São Paulo: Malheiros, 2.007 .

MACHADO, Rubens Approbato (coord.). Comentários à nova Lei de Falências $e$ Recuperação de Empresas. $1^{\mathrm{a}}$ ed. São Paulo: Quartier Latin, 2.005.

MACLACHLAN, James Angell. The title and rights of the trustee in bankruptcy. In Rutgers Law Review. Vol. XIV, 1.960. Number 4.

MANDEL, Julio Kahan. Nova Lei de Falências e Recuperação de Empresas anotada. Lei n. 11.101, de 9 de fevereiro de 2005. $1^{\mathrm{a}}$ ed. São Paulo: Saraiva, 2.005. 
MANGE, Renato. O Administrador Judicial, o Gestor Judicial e o Comitê de Credores na Lei $\mathrm{n}^{\mathrm{o}}$ 11.101/05. In: SANTOS, Paulo Penalva (coord.). A Nova Lei de Falências e Recuperação de Empresas. Lei 11.101/05. 1ª ed. Rio de Janeiro: Forense, 2.007.

MARTINS, Fran. Curso de direito comercial. 30ª ed. São Paulo: Forense, 2.006.

MCBRYDE, William W., FLESSNER, Axel, KORTMANN, Sebastian C. J. J. (coord.). Principles of European Insolvency Law. Law of Business and Finance volume 4. $1^{\mathrm{a}}$ ed. Deventer: Kluwer Legal Publishers, 2.003.

MCCULLOUGH, Elizabeth H. Bankruptcy Trustee Liability: is there a method in the madness? In: Lewis \& Clark Law Review, Vol. 15, 2.001.

MEDAUAR, Odete. Direito Administrativo Moderno. $18^{\mathrm{a}}$ ed. São Paulo: Revista dos Tribunais, 2014.

MEIRELLES, Hely Lopes. Direito Administrativo Brasileiro. $26^{\mathrm{a}}$ ed. São Paulo: Malheiros, 1990,

MENDEZ, Joaquin Bisbal. La empresa en crisis y el derecho de quiebras (Una aproximación económica y jurídica a los procedimientos de conservación de empresas). Bolonha: Real Colegio de España, 1.986.

MENDONÇA, José Xavier Carvalho de. Tratado de Direito Comercial. Vol. VIII. $2^{\text {a }}$. ed. Rio de Janeiro: Freitas Bastos, 1.962.

MIGLARI JÚNIOR, ARTHUR. In: TOLEDO, Paulo Fernando Campos Salles de, e ABRÃO, Carlos Henrique (coord.). Comentários à Lei de Recuperação de Empresas e Falência, $4^{\mathrm{a}}$. ed. São Paulo: Saraiva, 2.010.

MONTEIRO JÚNIOR, Ney Caminha. O Administrador Judicial e a Fiscalização do Plano de Recuperação. In: Principais Controvérsias na Nova Lei de Falências. BATTELLO, Silvio Javier (org.). $1^{\text {a }}$. ed. Porto Alegre: Sergio Antonio Fabris, 2.008. 
MOREIRA, Alberto Camiña. In: CÔRREA-LIMA, Osmar Brina e LIMA, Sérgio Mourão Corrêa (coord.). Comentários à Nova lei de Falência e Recuperação de Empresas: Lei $n^{o}$ 11.101, de 09 de fevereiro de 2005. $1^{\text {a }}$ ed. Rio de Janeiro: Forense, 2.009.

In: CASTRO, Rodrigo R. Monteiro de e ARAGÃO, Leandro Santos de (coord.). Direito Societário e a Nova Lei de Falências e Recuperação de Empresas. São Paulo: Quartier Latin, 2.006.

MUNHOZ, Eduardo Secchi. In: SOUZA JUNIOR, Francisco Satiro de, e PITOMBO, Antônio Sérgio de A. Moraes. (coord.). Comentários à Lei de Recuperação de Empresas e Falência. Lei 11.101/2005. - Artigo por Artigo. $2^{\text {a }}$ ed. São Paulo: Revista dos Tribunais, 2.007 .

NEGRÃO, Ricardo. Manual de Direito Comercial e de Empresa. Vol. 3. 1ª ed. São Paulo: Saraiva, 2.004.

Aspectos Objetivos da Lei de Recuperação de Empresas e de Falências: Lei 11.101, de 09 de fevereiro de 2005. $1^{\text {a }}$. ed. São Paulo: Saraiva, 2.005.

NORONHA, Edgar Magalhães. Direito Penal, vol. IV, $8^{\text {a }}$ ed. São Paulo: Saraiva, 1.972.

OLIVEIRA, Fábio Leopoldo. Responsabilidade Tributária. In: MARTINS, Ives Gandra da Silva (coord.). Curso de Direito Tributário. $7^{\mathrm{a}}$ ed. São Paulo: Saraiva, 2.000.

PAES DE ALMEIDA, Amador. Curso de Falência e Concordata. 18 ${ }^{\mathrm{a}}$ ed. São Paulo: Saraiva, 2.000 .

PAES, P. R. Tavares. Curso de falências e concordatas. $1^{\text {a }}$ ed. São Paulo: Lejus, 1.998.

PAIVA, Luiz Fernando Valente de (coord.). Direito falimentar e a Nova Lei de Falências e Recuperação de Empresas.1 ${ }^{\mathrm{a}}$ ed. São Paulo: Quartier Latin, 2.005.

PARENTE, Flávia. O Dever de Diligência dos Administradores de Sociedades Anômimas. $1^{\mathrm{a}}$ ed. Rio de Janeiro: Renovar, 2.005. 
PERIN JÚNIOR, Ecio. Curso de direito falimentar. $2^{\text {a }}$ ed. São Paulo: Método, 2.004.

O Administrador Judicial e o Comitê de Credores no Novo Direito Concursal Brasileiro. In: PAIVA, Luiz Fernando Valente de (coord.). Direito falimentar e a Nova Lei de Falências e Recuperação de Empresas. 1a ed. São Paulo: Quartier Latin, 2.005 .

PENTEADO, Mauro Rodrigues. In: SOUZA JUNIOR, Francisco Satiro de, e PITOMBO, Antônio Sérgio de A. Moraes (coord.). Comentários à Lei de Recuperação de Empresas e Falência. Lei 11.101/2005. - Artigo por Artigo. $2^{\mathrm{a}}$ ed. São Paulo: Revista dos Tribunais, 2.007 .

In: CÔRREA-LIMA, Osmar Brina e LIMA, Sérgio Mourão Corrêa (coord.). Comentários à Nova lei de Falência e Recuperação de Empresas: Lei no 11.101, de 09 de fevereiro de 2005. $1^{\text {a }}$ ed. Rio de Janeiro: Forense, 2.009.

PEREIRA, Alexandre Demetrius. Crimes falimentares - Teoria, Prática e Questões de Concursos Comentadas. $1^{\mathrm{a}}$ ed. São Paulo: Malheiros, 2.010.

PIMENTA, Eduardo Goulart. Recuperação de Empresas: um estudo sistematizado da nova lei de falências. $1^{\mathrm{a}}$ ed. São Paulo: IOB Thomson, 2.006.

Atribuições e Perfil do Administrador Judicial, Gestor Judicial e Comitê de Credores no Contexto da Lei n. 11.101/05. In: Direito Falimentar Contemporâneo. CASTRO, Moema A.S. de e CARVALHO, William Eustáquio de (coord.). $1^{\mathrm{a}}$. ed. Porto Alegre: Sergio Antonio Fabris, 2.008.

PLAZAS, José Machado. La administración concursal. Revista Jurídica de Catalunha. Vol. 103, n. 4, 2004. In: http://www.icab.cat/files/242-148054DOCUMENTO/bMachado.pdf. acesso em 21/04/2.014.

PONTES DE MIRANDA, Francisco Cavalcanti. Tratado de Direito Privado. Parte Especial. Tomo XXIX. Direito das Obrigações. Atualizado por Manuel Justino Bezerra Filho. São Paulo: Revista dos Tribunais, 2.012. 
Tratado de Direito Privado. Tomo XLIX. São Paulo: Revista dos

Tribunais, 1.972 .

PRADO, Viviane Muller. Conflito de interesses de grupos societários. $1^{\mathrm{a}}$ ed. São Paulo: Quartier Latin, 2.006.

PRIMACK, David P. Confusion and solution: Chapter 11 bankruptcy trustee's standard of care for personal liability. In William and Mary Law Review. Rev. 1297, Vol. 43, 20012002.

PROENÇA, José Marcelo Martins. Os novos horizontes do direito concursal - uma crítica ao continuísmo prescrito pela Lei 11.101/2005. Revista de Direito Mercantil Industrial, Econômico e Financeiro n. 151, São Paulo: Malheiros 2.009.

PROVINCIALI, Renzo. Trattado di Diritto Fallimentare. Vol. I. Milão, Dott. A. Giuffrè Editore, 1974.

PUGLIESI, Adriana Valéria. Direito Falimentar e Preservação da Empresa. São Paulo: Quartier Latin, 2.013.

RADWAN, Theresa J. Pulley. Trustees in Trouble: Holding Bankruptcy Trustees Personally Liable for Professional Negligence. In: Connecticut Law Review. Vol. 35, 2.003.

RAMALHO, Tiago. O Estatuto do Administrador de Insolvência. In: De LUCCA, Newton, e VASCONCELOS, Miguel Pestana de (org.). Falência, insolvência e recuperação de empresas. Estudos luso-brasileiros. São Paulo: Quartier Latin. No prelo.

REQUIÃO, Rubens. Curso de direito falimentar. Falência. $1^{\mathrm{o}}$ Vol. $6^{\mathrm{a}}$ ed. São Paulo: Saraiva, 1.981.

Curso de direito comercial. $23^{\mathrm{a}}$ ed. São Paulo: Saraiva.

A Crise do Direito Falimentar Brasileiro - Reforma da Lei de Falências. Revista de Direito Mercantil, vol. 14, São Paulo: Revista dos Tribunais, 1.974. 
RIBEIRO, Renato Ventura. Dever de Diligência dos Administradores de Sociedades. $1^{\mathrm{a}}$ ed. São Paulo: Quartier Latin, 2.006.

RODRÍGUEZ, Enrique Barrero. La responsabilidad de los administradores concursales y auxiliares delegados en la ley concursal. Acesso em 10/04/14 http://sodbib.udl.es/gtb/sod/usu/\$UDLG/repositorio/20331345_23303779.pdf

ROJO, Ángel e BELTRÁN, Emilio. Comentario de la Ley Concursal. Tomo I. $1^{\mathrm{a}}$ ed. Madrid: Civitas Ediciones, SL, 2.004.

SAINT-ALARY-HOUIN, Corinne. Droit des entreprises em difficulté. $7^{\mathrm{a}}$. ed. Paris: Montchrestien, 2.011.

SALOMÃO, Luis Felipe e SANTOS, Paulo Penalva. Recuperação Judicial, Extrajudicial e Falência: Teoria e Prática. $1^{\mathrm{a}}$ ed. Rio de Janeiro: Forense, 2.012.

SANTOS, José Vanderlei Masson dos. Da atuação do perito contador na Nova lei de Falências e Recuperação de Empresas. In: DELUCCA, Newton, e DOMINGUES, Alessandra de Azevedo (coord.). Direito Recuperacional. Aspectos teóricos e práticos. $1^{\text {a }}$ ed. São Paulo: Quartier Latin, 2.012.

SANTOS, Paulo Penalva (coord.). A Nova Lei de Falências e Recuperação de Empresas. Lei 11.101/05. $1^{\mathrm{a}}$ ed. Rio de Janeiro: Forense, 2.007.

SCARBERRY, Mark S., KLEE, Kenneth N., NEWTON, Grant W., e NICKLES, Steve H. Business Reorganization in Bankruptcy: Cases and Materials. $2^{\mathrm{a}}$. ed. Minnesota: West Group, 2.001.

SCHOUERI, Luis Eduardo. Direito Tributário. São Paulo: Saraiva, 2.011.

SEBASTIÁN, Rafael. Aproximación a la reforma del derecho concursal. http://www.uria.com/documentos/publicaciones/1093/documento/02Rafael.pdf?id=2017. Acesso em 10/04/14. 
SILVA, Jane. In: CÔRREA-LIMA, Osmar Brina e LIMA, Sérgio Mourão Corrêa (coord.). Comentários à Nova lei de Falência e Recuperação de Empresas: Lei no 11.101, de 09 de fevereiro de 2005. $1^{\text {a }}$ ed. Rio de Janeiro: Forense. 2.009.

SILVA, De Plácido e. Vocabulário Jurídico. $11^{\text {a }}$ ed. Rio de Janeiro: Forense, 1.989.

SOUZA JUNIOR, Francisco Satiro de, e PITOMBO, Antônio Sérgio de A. Moraes. (coord.). Comentários à Lei de Recuperação de Empresas e Falência. Lei 11.101/2005. Artigo por Artigo. $2^{\text {a }}$ ed. São Paulo: Revista dos Tribunais, 2.007.

.In: SOUZA JUNIOR, Francisco Satiro de, e PITOMBO, Antônio Sérgio de A. Moraes. (coord.). Comentários à Lei de Recuperação de Empresas e Falência. Lei 11.101/2005. - Artigo por Artigo. $2^{\text {a }}$ ed. São Paulo: Revista dos Tribunais, 2.007 .

STOCO, Rui e TATIANA de O Stoco. FRANCO, Alberto Silva e STOCO, Rui (coord.). Código Penal e sua interpretação: doutrina e jurisprudência. $8^{\mathrm{a}}$ ed. São Paulo: Revista dos Tribunais, 2.007.

SZTAJN, Rachel. Teoria jurídica da empresa: atividade empresária e mercados. São Paulo: Atlas, 2004.

. In: TOLEDO, Paulo Fernando Campos Salles de, e ABRÃO, Carlos Henrique (coord.). Comentários à Lei de Recuperação de Empresas e Falência, $4^{\mathrm{a}}$. ed. São Paulo: Saraiva, 2.010.

SZTAJN, Rachel, TOLEDO, Paulo Fernando Campos Salles de, SILVA, Fernando César Nimer Moreira da. National Report for Brazil. In: FABER, Dennis, VERMUT, Niels, KILBORN, Jason e RICHTER, Tomás Commencement of Insolvency Proceedings. Oxford: Oxford University Press, 2.012.

TABB, Charles Jordan. The law of bankruptcy. Nova Iorque: The Foudantion Press, Inc. 1.997. 
TEBET, Ramez. Parecer 534/04 sobre o Projeto de Lei Complementar n. 71/2.003. Disponível em: http://redir.stf.jus.br/paginadorpub/paginador.jsp?docTP=TP\&docID=580930. Acesso em 01/07/14.

TEPEDINO, Ricardo. In: TOLEDO, Paulo Fernando Campos Salles de, e ABRÃO, Carlos Henrique (coord.). Comentários à Lei de Recuperação de Empresas e Falência, ${ }^{\mathrm{a}}{ }^{\mathrm{a}}$. ed. São Paulo: Saraiva, 2.010.

THEODORO JÚNIOR, Humberto. Curso de Direito Processual Civil - Procedimentos Especiais. 42 ${ }^{\mathrm{a}}$ ed. Rio de Janeiro: Forense, 2.010.

TILLER, E. Allan. Personal Liability of Trustees and Receivers in Bankruptcy. In American Bankruptcy Law Journal 75. Vol. 53, 1.979.

TIRADO, Ignácio. National Report for Spain. In: FABER, Dennis, VERMUT, Niels, KILBORN, Jason e RICHTER, Tomás. Commencement of Insolvency Proceedings. Oxford: Oxford University Press, 2.012.

. Del nombramiento de los administradores concursales. In: Comentario de la Ley Concursal. ROJO, Ángel e BELTRÁN, Emilio. Tomo I. $1^{\mathrm{a}}$ ed. Madrid: Civitas Ediciones, SL, 2.004.

TRIBUNAL DE JUSTIÇA DO ESTADO DO RIO DE JANEIRO. Corregedoria Geral de Justiça. Disponível em http://www.tjrj.jus.br/documents/1017893/1038412/cncgjjudicial.pdf. Acesso em 02/02/2.014.

TRIBUNAL DE JUSTIÇA DO ESTADO DE SÃO PAUlO. Conselho Superior de magistratura. Disponível em: http://esaj.tjsp.jus.br/genPtl/abrirDetalhesLegislacao.do?cdLegislacaoEdit=34732\&flBtVol $\underline{\operatorname{tar}=\mathrm{N}}$. Acesso em 01/10/2.013. 
TOLEDO, Paulo Fernando Campos Salles de. A disciplina Jurídica das Empresas em Crise no Brasil: Sua Estrutura Institucional. In: Revista de Direito Mercantil, Industrial, Econômico e Financeiro n. 122, São Paulo: Malheiros, 2.001.

A preservação da empresa, mesmo na falência. In: DE LUCCA, Newton e DOMINGUES, Alessandra de Azevedo (coord.). Direito Recuperacional Aspectos Teóricos e Práticos, $1^{\mathrm{a}}$ ed. São Paulo: Quartier Latin, 2.009.

Recuperação judicial: a principal inovação da Lei de Recuperação de Empresas - LRE. In: A Nova Lei de Falências e de Recuperação de Empresas. Revista do Advogado n. 83, São Paulo: AASP, 2.005.

A empresa em Crise no Direito Francês e Americano. Dissertação de mestrado. Faculdade de Direito da Universidade de São Paulo. São Paulo, 1.987.

A reforma da Lei de Falências e a experiência do Direito Estrangeiro. In: Homenagem a Roger Carvalho Mange. Revista do Advogado n. 36, São Paulo: AASP, 1.992.

Da personificação da massa falida. In: Revista de Direito Mercantil vol. 78. São Paulo: Revista dos Tribunais, 1.990.

TOLEDO, Paulo Fernando Campos Salles de, e ABRÃO, Carlos Henrique (coord.). Comentários à Lei de Recuperação de Empresas e Falência, 4a. ed. São Paulo: Saraiva, 2.010 .

TOLEDO, Paulo Fernando Campos Salles de, e SOUZA JUNIOR, Francisco Satiro de (coord.). Direito das Empresas em Crise: Problemas e Soluções. $1^{\mathrm{a}}$ ed. São Paulo: Quartier Latin, 2.012.

TZIRULNIK, Luiz. Direito Falimentar. $7^{\mathrm{a}}$ ed. São Paulo: Revista dos Tribunais, 2.005. 
U.S. DEPARTMENT OF JUSTICE. Handbook for Chapter 7 Trustees. Disponível em http://www.justice.gov/ust/eo/private trustee/library/chapter07/docs/7handbook0301/Ch7h b0702.pdf. Acesso em 02/05/2.014.

U.S. DEPARTMENT OF JUSTICE. Chapter 11 Trustee Handbook. Disponível em http://www.justice.gov/ust/eo/private_trustee/library/chapter11/docs/Ch11Handbook200405.pdf. Acesso em 02/05/2.014

VALLADÃO, Erasmo e FRANÇA, Azevedo e Novaes. Conflito de Interesses nas Assembleias de S.A.1 ${ }^{\mathrm{a}}$ ed. São Paulo: Malheiros, 1.993.

Temas de Direito Societário, Falimentar e Teoria da Empresa. $1^{\mathrm{a}}$ ed. São Paulo: Malheiros, 2.009.

VALVERDE, Trajano de Miranda. Comentários à Lei das Falências. (Decreto-lei $n^{o} 7.661$, de 21 de junho de 1945). Vol. I (arts $1^{\circ}$ a 51). $4^{\mathrm{a}}$ ed. rev. e atualizada por J. A. Penalva Santos e Paulo Penalva Santos. Rio de Janeiro: Revista Forense, 1.999.

Comentários à Lei das Falências. (Decreto-lei $n^{\circ} 7.661$, de 21 de junho de 1945). Vol. II (arts. 52 a 113). $4^{\text {a }}$ ed. rev. e atualizada por J. A. Penalva Santos e Paulo Penalva Santos. Rio de Janeiro: Revista Forense, 1.999.

Comentários à Lei das Falências. (Decreto-lei nº 7.661, de 21 de junho de 1945). Vol. III (arts. 114 a 199). $2^{\mathrm{a}}$ ed. Rio de Janeiro: Revista Forense, 1.955.

VASCONCELOS, Pedro Pais de. Responsabilidade civil do administrador de insolvência. In: II Congresso de Direito da Insolvência. Serra, Catarina (coord.). Coimbra: Almedina, 2.014 .

VERÇOSA, Haroldo Malheiros Duclerc. In: SOUZA JUNIOR, Francisco Satiro de, e PITOMBO, Antônio Sérgio de A. Moraes (coord.). Comentários à Lei de Recuperação de Empresas e Falência. Lei 11.101/2005. - Artigo por Artigo. 2a ed. São Paulo: Revista dos Tribunais, 2.007. 
Curso de direito comercial. Teoria Geral das Sociedades - As Sociedades em Espécie do Código Civil. Vol. 2. São Paulo: Malheiros, 2.006.

VIGIL NETO, Luiz Inácio. Teoria Falimentar e Regimes Recuperatórios: Estudos sobre a Lei 11.101/2005. Porto Alegre: Livraria do Advogado, 2.008.

VILLARREAL, Alberto Muñoz e LAGUNA, Pilar Monsalve. La responsabilidad civil de administradores concursales y auxiliares delegados. http://www.munozarribas.com/proyectos/userfiles/file/La\%20Responsabilidad\%20Civil\%20de\%20Administr adores\%20Concursales\%20y\%20Auxiliares\%20Delegados.pdf. Acesso em 10/04/14.

WESTBROOK, Jay Lawrence, BOOTH, Charles D., PAULUS, Christoph G., RAJAK, Harry. A Global View of Business Insolvency Systems. Washington, DC: The World Bank, 2.010 .

WORLD BANK. Principles and Guidelines for Effective Insolvency and Creditor Rights Systems. Disponível em: http://www.worldbank.org/ifa/Insolvency\%20Principles\%20and\%20Guidelines\%20April \%202001.pdf. Acesso em 17/04/14.

YÁSGÜEZ, Ricardo de Angel. Responsabilidad de la Administración concursal. http://www.asociacionabogadosrcs.org/doctrina/responsabilidad-de-la-administracionconcursal.pdf. Acesso em 10/04/14. 